Prepared in cooperation with the California State Water Resources Control Board A product of the California Groundwater Ambient Monitoring and Assessment (GAMA) Program

\title{
Status and Understanding of Groundwater Quality in the Bear Valley and Lake Arrowhead Watershed Study Unit, 2010: California GAMA Priority Basin Project
}

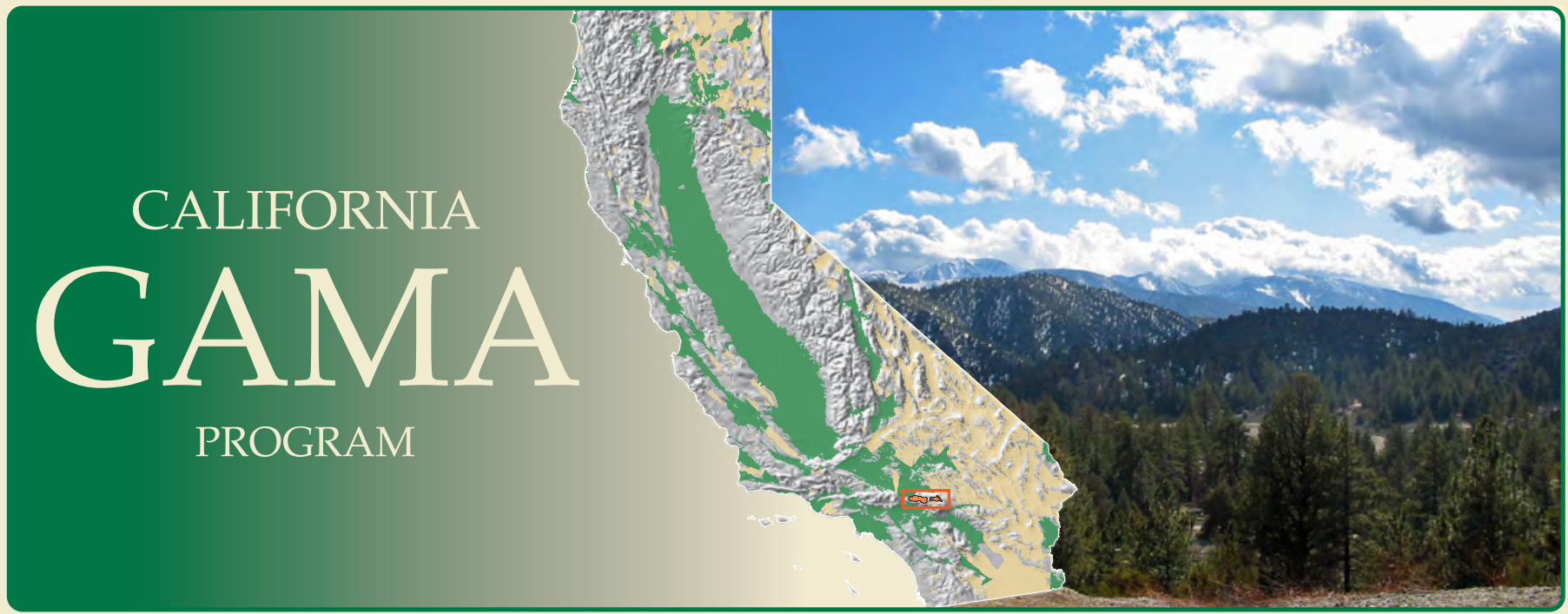

Scientific Investigations Report 2017-5043 


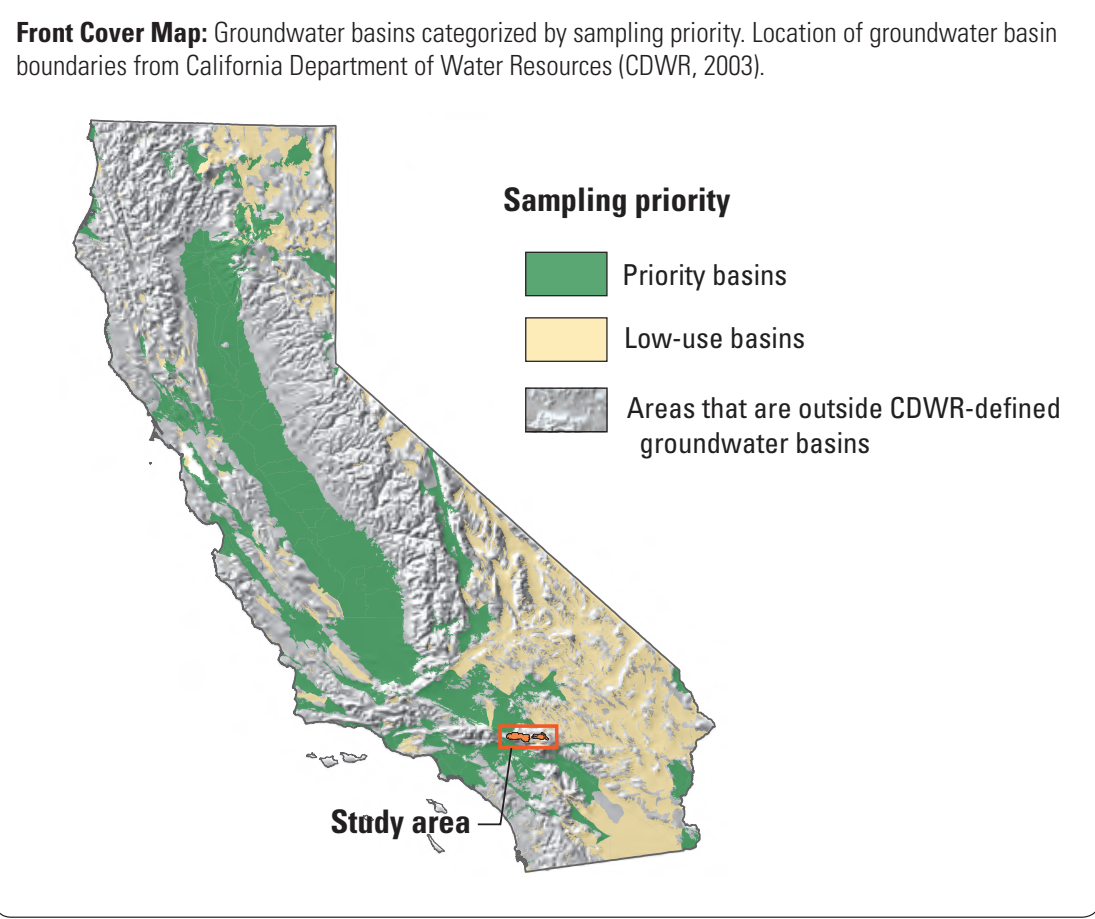

\section{Cover photographs:}

Front cover: View of mountains near Big Bear Lake, California. (Photograph taken by Jennifer Shelton, U.S. Geological Survey).

Back cover: Well near Lake Arrowhead, California. (Photograph taken by Tracy Davis, U.S. Geological Survey). 


\section{Status and Understanding of Groundwater Quality in the Bear Valley and Lake Arrowhead Watershed Study Unit, 2010: California GAMA Priority Basin Project}

By Timothy M. Mathany and Carmen A. Burton

A product of the California Groundwater Ambient Monitoring and Assessment (GAMA) Program, in cooperation with the California State Water Resources Control Board

Scientific Investigations Report 2017-5043 


\title{
U.S. Department of the Interior \\ RYAN K. ZINKE, Secretary
}

\section{U.S. Geological Survey William H. Werkheiser, Acting Director}

\author{
U.S. Geological Survey, Reston, Virginia: 2017
}

For more information on the USGS - the Federal source for science about the Earth, its natural and living resources, natural hazards, and the environment—visit http://www.usgs.gov or call 1-888-ASK-USGS.

For an overview of USGS information products, including maps, imagery, and publications, visit http://www.usgs.gov/pubprod/.

Any use of trade, firm, or product names is for descriptive purposes only and does not imply endorsement by the U.S. Government.

Although this information product, for the most part, is in the public domain, it also may contain copyrighted materials as noted in the text. Permission to reproduce copyrighted items must be secured from the copyright owner.

Suggested citation:

Mathany, T.M., and Burton, C.A., 2017, Status and understanding of groundwater quality in the Bear Valley and Lake Arrowhead Watershed Study Unit, 2010: California GAMA Priority Basin Project: U.S. Geological Survey Scientific Investigations Report 2017-5043, 71 p., https://doi.org/10.3133/sir20175043.

ISSN 2328-0328 (online) 


\section{Contents}

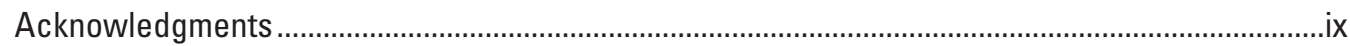

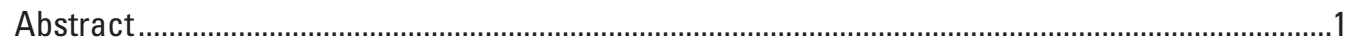

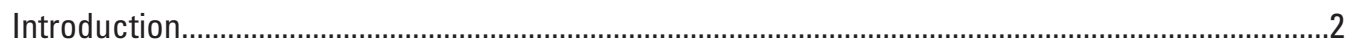

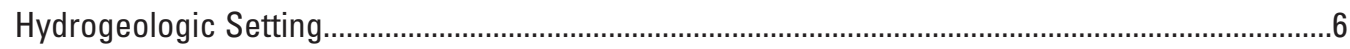

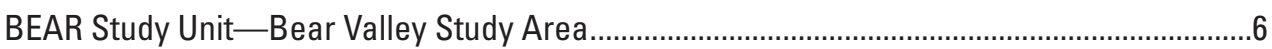

BEAR Study Unit—Lake Arrowhead Watershed Study Area.....................................................9

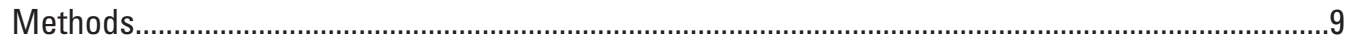

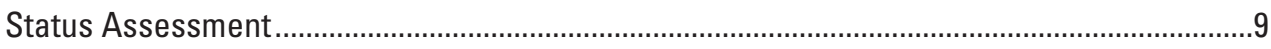

Groundwater Quality Defined as Relative Concentrations ............................................

Datasets Used for Status Assessment...........................................................................10

U.S. Geological Survey Randomized Sites .................................................................10

U.S. Geological Survey Non-Randomized Sites ............................................................11

California Division of Drinking Water (SWRCB-DDW) Dataset..........................................11

Selection of Constituents for Discussion........................................................................12

Calculation of Aquifer-Scale Proportions ....................................................................12

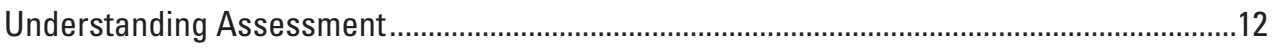

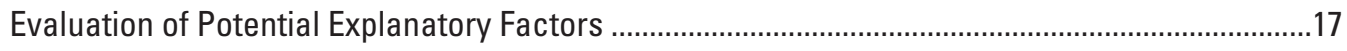

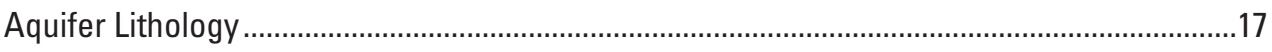

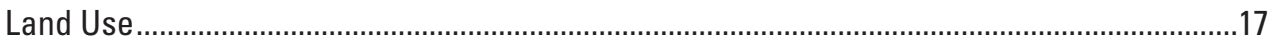

Density of Septic Tanks and Leaking Underground Fuel Tanks .............................................19

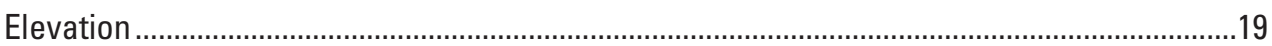

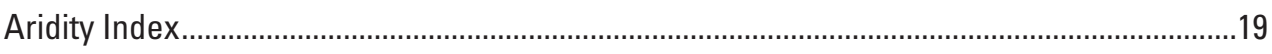

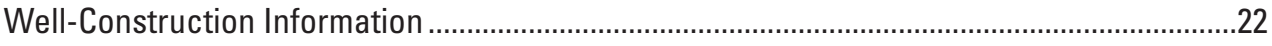

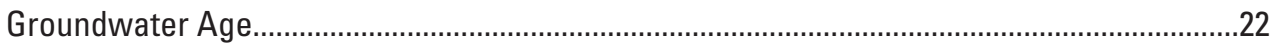

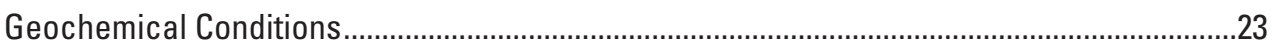

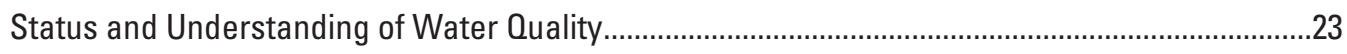

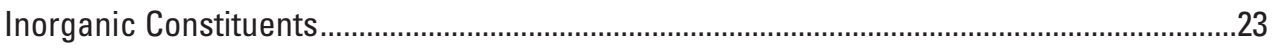

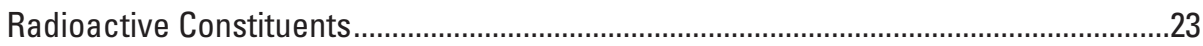

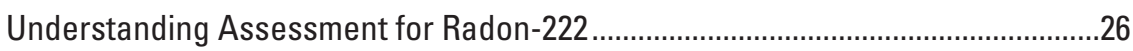

Understanding Assessment for Uranium and Gross Alpha Radioactivity...............29

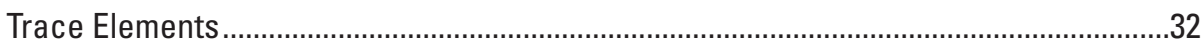

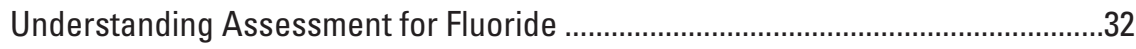

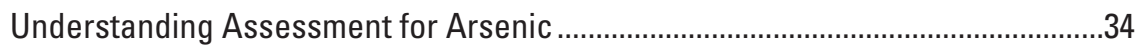

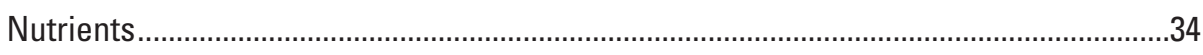

Inorganic Constituents with Aesthetic-Based Benchmarks.........................................34 


\section{Contents-Continued}

Organic and Special-Interest Constituents ..............................................................................36

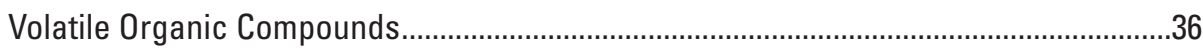

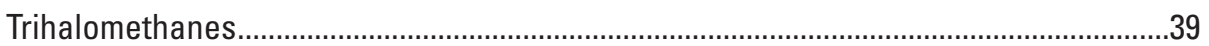

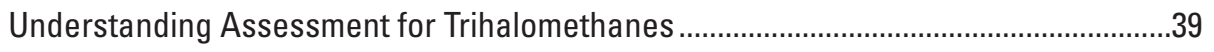

Gasoline Components .............................................................................................

Understanding Assessment for Methyl Tert-Butyl Ether (MTBE) ...................................41

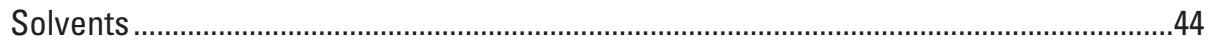

Understanding Assessment for Solvents ...................................................................44

Pesticides and Pesticide Degradates .........................................................................

Understanding Assessment for Simazine .....................................................................46

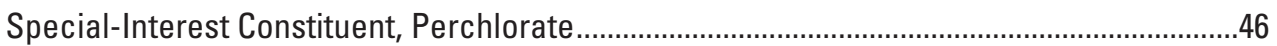

Understanding Assessment for Perchlorate ..................................................................46

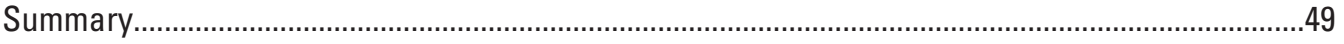

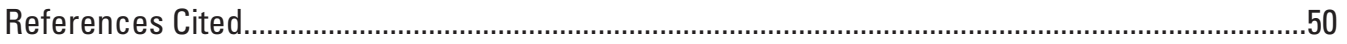

Appendix 1. Attribution of Potential Explanatory Factors ……………….........................................57

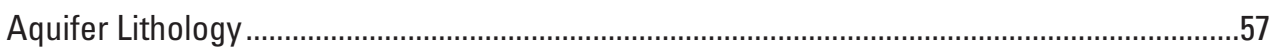

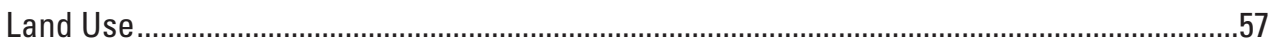

Septic Tank and Leaking (or Formerly Leaking) Underground Fuel-Tank Density ...................57

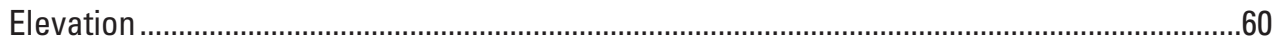

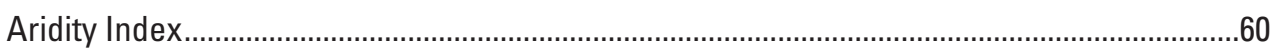

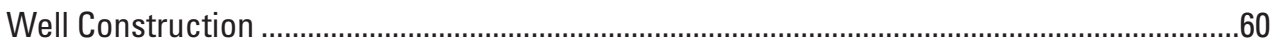

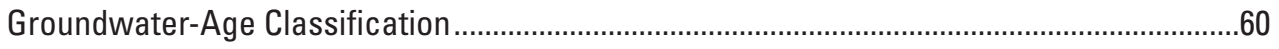

Oxidation-Reduction Condition, Dissolved Oxygen Concentration, and pH .........................63

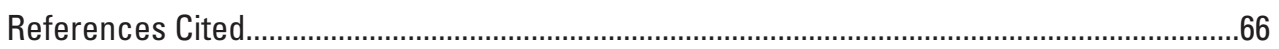

Appendix 2. Additional Water-Quality Data ..............................................................................69

References Cited.............................................................................................................. 


\section{Figures}

1. Maps showing the California hydrogeologic provinces and location of selected study areas of the California Priority Basin Project, specifically, the Bear Valley and Lake Arrowhead Watershed study unit and the Bear Valley and Lake Arrowhead Watershed study areas.

2. Maps showing the study area, grid cells, U.S. Geological Survey grid and understanding sites, and California Division of Drinking Water sites in the study areas of the Bear Valley and Lake Arrowhead Watershed study unit, California Groundwater Ambient Monitoring and Assessment Priority Basin Project..

3. Maps showing geology and U.S. Geological Survey-sampled sites in the study areas of the Bear Valley and Lake Arrowhead Watershed study unit, California Groundwater Ambient Monitoring and Assessment Priority Basin Project.. .8

4. Graph showing frequency of aquifer lithology and by site type and study area for the U.S. Geological Survey grid and understanding sites in the Bear Valley and Lake Arrowhead Watershed study areas, 2010, California Groundwater Ambient Monitoring and Assessment Priority Basin Project.

5. Ternary diagrams showing 2001 land use as the percentage of urban, agricultural, and natural land uses in the Bear Valley and Lake Arrowhead Watershed study unit, California Groundwater Ambient Monitoring and Assessment Priority Basin Project.

6. Maps showing 2001 land use and location of leaking (or formerly leaking) underground fuel tanks in two California Groundwater Ambient Monitoring and Assessment Priority Basin Project study areas.

7. Graph showing well depth for the U.S. Geological Survey grid and understanding wells in the Bear Valley and Lake Arrowhead Watershed study areas, 2010, California Groundwater Ambient Monitoring and Assessment Priority Basin Project...22

8. Graph showing frequency by age class of groundwater age, grouped by site type and by study area, for samples from the U.S. Geological Survey grid and understanding sites in the Bear Valley and Lake Arrowhead Watershed study areas, 2010, California Groundwater Ambient Monitoring and Assessment Priority Basin Project...22

9. Graph showing maximum relative concentration of constituents detected in groundwater samples from U.S. Geological Survey grid sites, by constituent class, Bear Valley and Lake Arrowhead Watershed study unit, 2010, California Groundwater Ambient Monitoring and Assessment Priority Basin Project.

10. Graphs showing relative concentrations of selected constituents in groundwater samples from U.S. Geological Survey grid sites, Bear Valley and Lake Arrowhead Watershed study unit, 2010, California Groundwater Ambient Monitoring and Assessment Priority Basin Project.

11. Maps showing geologic features and relative concentrations of radon-222 in groundwater samples from U.S. Geological Survey grid and understanding sites in two study areas of the California Groundwater Ambient Monitoring and Assessment Priority Basin Project, 2010.

12. Maps showing geologic features and relative concentrations of uranium in groundwater samples from U.S. Geological Survey grid and understanding sites (2010) and from California Division of Drinking Water sites (April 1, 2007-April 1, 2010) in two study areas of the California Groundwater Ambient Monitoring and Assessment Priority Basin Project. 


\section{Figures-Continued}

13. Scatterplot showing relation of uranium concentration to unadjusted gross alpha radioactivity in groundwater samples from the California Division of Drinking Water sites (April 1, 2007-April 1, 2010) in the Bear Valley and Lake Arrowhead Watershed study unit, California Groundwater Ambient Monitoring and Assessment Priority Basin Project.

14. Scatterplot showing relations of uranium concentration to tritium activity in groundwater, aquifer lithology, and study area of U.S. Geological Survey grid and understanding sites sampled in the Bear Valley and Lake Arrowhead Watershed study unit, 2010, California Groundwater Ambient Monitoring and Assessment Priority Basin Project.

15. Maps showing geologic features and relative concentrations of fluoride in groundwater samples from U.S. Geological Survey grid and understanding sites (2010) and from California Division of Drinking Water sites (April 1, 2007-April 1, 2010) in two study areas of the California Groundwater Ambient Monitoring and Assessment Priority Basin Project

16. Scatterplot showing relation of fluoride concentration to tritium activity in groundwater samples from U.S. Geological Survey grid sites in the Bear Valley and Lake Arrowhead Watershed study unit, 2010, California Groundwater Ambient Monitoring and Assessment Priority Basin Project.

17. Maps showing geologic features and relative concentrations of arsenic in groundwater samples from U.S. Geological Survey grid and understanding sites (2010) and California Division of Drinking Water sites (April 1, 2007-April 1, 2010) in two study areas of the California Groundwater Ambient Monitoring and Assessment Priority Basin Project

18. Maps showing geologic features and relative concentrations of iron in groundwater samples from U.S. Geological Survey grid and understanding sites (2010) and California Division of Drinking Water sites (April 1, 2007-April 1, 2010) in two study areas of California Groundwater Ambient Monitoring and Assessment Priority Basin Project

19. Maps showing geologic features and relative concentrations of manganese in groundwater samples from U.S. Geological Survey grid and understanding sites (2010) and California Division of Drinking Water sites (April 1, 2007-April 1, 2010) in two study areas of the, California Groundwater Ambient Monitoring and Assessment Priority Basin Project

20. Scatterplot showing frequency of detection and maximum relative concentration of organic and special-interest constituents in groundwater samples from U.S. Geological Survey grid sites, Bear Valley and Lake Arrowhead Watershed study areas, 2010, California Groundwater Ambient Monitoring and Assessment Priority Basin Project.

21. Maps showing 2001 land use, location of leaking (or formerly leaking) underground fuel tanks, and relative concentrations of trihalomethanes in groundwater samples from U.S. Geological Survey grid and understanding sites (2010) and from California Division of Drinking Water sites (April 1, 2007-April 1, 2010) for two study areas of the California Groundwater Ambient Monitoring and Assessment Priority Basin Project

22. Scatterplot showing relation of 2001 urban land use to trihalomethane concentration in samples from U.S. Geological Survey grid sites, by study area, Bear Valley and Lake Arrowhead Watershed study unit, 2010, California Groundwater Ambient Monitoring and Assessment Priority Basin Project. 


\section{Figures-Continued}

23. Maps showing land use, leaking (or formerly leaking) underground fuel-tanks, and relative concentrations of MTBE (methyl tert-butyl ether) in samples from U.S. Geological Survey grid and understanding sites (2010) and California Division of Drinking Water sites (April 1, 2007-April 1, 2010) in two study areas of the California Groundwater Ambient Monitoring and Assessment Priority Basin Project..

24. Scatterplot showing relation of MTBE (methyl tert-butyl ether) concentration to tritium activity (by study area and by dominant 2001 land use) in samples from U.S. Geological Survey grid sites, Bear Valley and Lake Arrowhead Watershed study unit, 2010, California Groundwater Ambient Monitoring and Assessment Priority Basin Project.

25. Maps showing 2001 land use and relative concentration of solvents in groundwater samples from U.S. Geological Survey grid and understanding sites (2010) and California Division of Drinking Water sites (April 1, 2007-April 1, 2010) in two study areas of the California Groundwater Ambient Monitoring and Assessment Priority Basin Project.

26. Maps showing 2001 land use and relative concentration of simazine in groundwater samples from U.S. Geological Survey grid and understanding sites (2010) and for California Division of Drinking Water sites (April 1, 2007-April 1, 2010) in two study areas of the California Groundwater Ambient Monitoring and Assessment Priority Basin Project.

27. Maps showing 2001 land use and relative concentrations of perchlorate in groundwater samples from U.S. Geological Survey grid and understanding sites (2010) and from California Division of Drinking Water sites (April 1, 2007-April 1, 2010) in two study areas of the California Groundwater Ambient Monitoring and Assessment Priority Basin Project.

\section{Tables}

1. Summary of sites sampled and constituent groups analyzed by the U.S. Geological Survey, Bear Valley and Lake Arrowhead Watershed study unit, 2010, California Groundwater Ambient Monitoring and Assessment Priority Basin Project..

2. Benchmark type and value and reporting limits for inorganic, organic, and specialinterest constituents either detected at moderate or high relative concentrations in groundwater samples collected by the U.S. Geological Survey (USGS) in 2010 or reported in California Division of Drinking Water database from 2007 to 2010, or, for organic constituents only, detected at any concentration in samples from more than 10 percent of USGS grid sites in either study area in 2010, Bear Valley and Lake Arrowhead Watershed study unit, California Groundwater Ambient Monitoring and Assessment Priority Basin Project.

3. Benchmark type and value and reporting limits for constituents detected in groundwater samples collected in 2010 by the U.S. Geological Survey either with no benchmarks or present only at low relative concentrations, Bear Valley and Lake Arrowhead Watershed study unit, California, Groundwater Ambient Monitoring and Assessment Priority Basin Project.

4. Constituents historically reported at concentrations greater than benchmarks in the California Division of Drinking Water database (July 6, 1982-March 31, 2007), but not during the 3-year period used in the status assessment for groundwater quality, Bear Valley and Lake Arrowhead Watershed study unit, April 1, 2007-April 1, 2010, California Groundwater Ambient Monitoring and Assessment Priority Basin Project...16 


\section{Tables-Continued}

5. Results of statistical tests using data for U.S. Geological Survey grid sites to identify significant differences between the Bear Valley and Lake Arrowhead Watershed study areas, 2010, California Groundwater Ambient Monitoring and Assessment Priority Basin Project.

6. Summary of aquifer-scale proportions by relative-concentration category for inorganic and organic constituent classes and selected constituents for groundwater in the Bear Valley and Lake Arrowhead Watershed study unit, 2010, California Groundwater Ambient Monitoring and Assessment Priority Basin Project.

7. Aquifer-scale proportions by relative-concentration category, for selected groundwater-quality constituents that met criteria for additional evaluation in the status assessment for the Bear Valley and Lake Arrowhead Watershed study unit, 2010, California Groundwater Ambient Monitoring and Assessment Priority Basin Project

1-1. Site-specific data for 2001 land use, septic tank density, leaking (or formerly leaking) underground fuel-tank density, and aquifer-lithology class for U.S. Geological Survey groundwater sites in the Bear Valley and Lake Arrowhead Watershed study unit, 2010, California Groundwater Ambient Monitoring and Assessment Priority Basin Project

1-2. Well and construction information and hydrologic conditions for U.S. Geological Survey grid and understanding sites in the Bear Valley and Lake Arrowhead Watershed study unit, California Groundwater Ambient Monitoring and Assessment Priority Basin Project.

1-3. Groundwater-age class and the associated data for samples from U.S. Geological Survey grid and understanding sites in the Bear Valley and Lake Arrowhead Watershed study unit, 2010, California Groundwater Ambient Monitoring and Assessment Priority Basin Project.

1-4. Oxidation-reduction class, dissolved oxygen concentration, and $\mathrm{pH}$ of samples from U.S. Geological Survey grid and understanding sites in the Bear Valley and Lake Arrowhead Watershed study unit, 2010, California Groundwater Ambient Monitoring and Assessment Priority Basin Project.

2-1. Analytical results from the Lawrence Livermore National Laboratory for dissolved noble gases and helium isotope ratios in groundwater samples collected by U.S. Geological Survey for the Bear Valley and Lake Arrowhead Watershed study unit, 2010, California Groundwater Ambient Monitoring and Assessment Priority Basin Project 


\section{Acknowledgments}

We especially thank the cooperating well owners and water purveyors for their generosity in allowing the U.S. Geological Survey to collect samples from their wells. Most of the funding for this work was provided by State of California bonds authorized by Proposition 50 and administered by the California State Water Resources Control Board. Additional funding was provided by U.S. Geological Survey Cooperative Matching Funds. This report is a product of the California State Water Resources Control Board Groundwater Ambient Monitoring and Assessment Program Priority Basin Project.

\section{Conversion Factors}

International System of Units to U.S. customary units

\begin{tabular}{lcl}
\hline \multicolumn{1}{c}{ Multiply } & \multicolumn{1}{c}{ By } & \multicolumn{1}{c}{ To obtain } \\
\hline Leter $(\mathrm{m})$ & \multicolumn{2}{c}{ Length } \\
kilometer $(\mathrm{km})$ & 3.281 & foot $(\mathrm{ft})$ \\
& 0.6214 & mile $(\mathrm{mi})$ \\
\hline square meter $\left(\mathrm{m}^{2}\right)$ & Area & square foot $\left(\mathrm{ft}^{2}\right)$ \\
square kilometer $\left(\mathrm{km}^{2}\right)$ & 10.76 & square mile $\left(\mathrm{mi}^{2}\right)$ \\
\hline & 0.3861 & \\
\hline becquerel per liter $(\mathrm{Bq} / \mathrm{L})$ & \multicolumn{2}{c}{ Radioactivity } \\
\hline
\end{tabular}

Temperature in degrees Celsius $\left({ }^{\circ} \mathrm{C}\right)$ may be converted to degrees Fahrenheit $\left({ }^{\circ} \mathrm{F}\right)$ as follows:

$$
{ }^{\circ} \mathrm{F}=\left(1.8 \times{ }^{\circ} \mathrm{C}\right)+32 .
$$

\section{Datum}

Vertical coordinate information is referenced to the North American Vertical Datum of 1988 (NAVD 88).

Horizontal coordinate information is referenced to the North American Datum of 1983 (NAD 83).

Depth, as used in this report, refers to distance below the land-surface datum and is reported as feet below land surface (ft bls). 


\section{Supplemental Information}

Concentrations of chemical constituents in water are given in either milligrams per liter (mg/L) or micrograms per liter $(\mu \mathrm{g} / \mathrm{L})$.

One milligram per liter is equivalent to 1 part per million (ppm); 1 microgram per liter is equivalent to 1 part per billion ( $\mathrm{ppb})$.

Concentrations of radioactive constituents in water are given in picocuries per liter ( $\mathrm{pCi} / \mathrm{L}$ ).

\section{Abbreviations}

$\begin{array}{ll}\text { AL-US } & \text { action level (EPA) } \\ \text { BEAR } & \text { Bear Valley and Lake Arrowhead Watershed study unit } \\ \text { BO } & \text { benchmark quotient } \\ \text { BV } & \text { Bear Valley study area } \\ \text { CDWR } & \text { California Department of Water Resources } \\ \text { DO } & \text { dissolved oxygen } \\ \text { EPA } & \text { U.S. Environmental Protection Agency } \\ \text { GAMA } & \text { Groundwater Ambient Monitoring and Assessment Program (USGS) } \\ \text { GIS } & \text { geographic information system } \\ \text { HBSL } & \text { Health-based screening level } \\ \text { LAW } & \text { Lake Arrowhead Watershed study area } \\ \text { LLNL } & \text { Lawrence Livermore National Laboratory, Livermore, California } \\ \text { LSD } & \text { land-surface datum } \\ \text { LUFT } & \text { leaking or formerly leaking underground fuel tank } \\ \text { MCL } & \text { maximum contaminant level } \\ \text { MCL-CA } & \text { maximum contaminant level (SWRCB-DDW) } \\ \text { MCL-US } & \text { maximum contaminant level (EPA) } \\ \text { MRL } & \text { minimum reporting level } \\ \text { MTBE } & \text { methyl tert-butyl ether } \\ \text { NAWOA } & \text { National Water-Quality Assessment Program (USGS) } \\ & \end{array}$




\section{Abbreviations-Continued}

$\begin{array}{ll}\text { NDMA } & \text { N-nitrosodimethylamine } \\ \text { NLCD } & \text { National Land Cover Dataset (USGS) } \\ \text { NWIS } & \text { National Water Information System (USGS) } \\ \text { PBP } & \text { priority basin project } \\ \text { PCE } & \text { perchloroethene, tetrachloroethene } \\ \text { pmc } & \text { percent modern carbon } \\ \text { PS code } & \text { Drinking Water Source identification number (SWRCB) } \\ \text { PVC } & \text { polyvinyl chloride } \\ \text { RC } & \text { relative concentration } \\ \text { redox } & \text { oxidation-reduction } \\ \text { rho } & \text { rank-order correlation coefficient } \\ \text { SIR } & \text { Scientific Investigation Report } \\ \text { SMCL } & \text { secondary maximum contaminant level } \\ \text { SMCL-CA } & \text { secondary maximum contaminant level (SWRCB-DDW) } \\ \text { SWRCB } & \text { California State Water Resources Control Board } \\ \text { SWRCB-DDW } & \text { California Division of Drinking Water (SWRCB) } \\ \text { TDS } & \text { total dissolved solids } \\ \text { TEAP } & \text { terminal electron acceptor process } \\ \text { THM } & \text { trihalomethane } \\ \text { TU } & \text { tritium unit } \\ \text { USGS } & \text { United States Geological Survey } \\ \text { VOC } & \text { volatile organic compound } \\ \text { WCR } & \text { well completion report } \\ \text { Z } & \text { test statistic for Wilcoxon test } \\ 1,1-D C E & 1,1 \text {-dichloroethene } \\ \text { 1,1,1-TCA } & 1,1,1 \text {-trichloroethane } \\ \text { 1,2,3-TCP } & 1,2,3-\text { trichloropropane } \\ \text { 14C } & \text { carbon-14 }\end{array}$




\title{
Status and Understanding of Groundwater Quality in the Bear Valley and Lake Arrowhead Watershed Study Unit, 2010: California GAMA Priority Basin Project
}

\author{
By Timothy M. Mathany and Carmen A. Burton
}

\section{Abstract}

Groundwater quality in the 112-square-mile Bear Valley and Lake Arrowhead Watershed (BEAR) study unit was investigated as part of the Priority Basin Project (PBP) of the Groundwater Ambient Monitoring and Assessment (GAMA) Program. The study unit comprises two study areas (Bear Valley and Lake Arrowhead Watershed) in southern California in San Bernardino County. The GAMA-PBP is conducted by the California State Water Resources Control Board (SWRCB) in cooperation with the U.S. Geological Survey (USGS) and the Lawrence Livermore National Laboratory.

The GAMA BEAR study was designed to provide a spatially balanced, robust assessment of the quality of untreated (raw) groundwater from the primary aquifer systems in the two study areas of the BEAR study unit. The assessment is based on water-quality collected by the USGS from 38 sites (27 grid and 11 understanding) during 2010 and on waterquality data from the SWRCB-Division of Drinking Water (DDW) database. The primary aquifer system is defined by springs and the perforation intervals of wells listed in the SWRCB-DDW water-quality database for the BEAR study unit.

This study included two types of assessments: (1) a status assessment, which characterized the status of the quality of the groundwater resource as of 2010 by using data from samples analyzed for volatile organic compounds, pesticides, and naturally present inorganic constituents, such as major ions and trace elements, and (2) an understanding assessment, which evaluated the natural and human factors potentially affecting the groundwater quality. The assessments were intended to characterize the quality of groundwater resources in the primary aquifer system of the BEAR study unit, not the treated drinking water delivered to consumers. Bear Valley study area and the Lake Arrowhead Watershed study area were also compared statistically on the basis of water-quality results and factors potentially affecting the groundwater quality.

Relative concentrations (RCs), which are sample concentration of a particular constituent divided by its associated health- or aesthetic-based benchmark concentrations, were used for evaluating the groundwater quality for those constituents that have Federal or California regulatory or non-regulatory benchmarks for drinking-water quality. An RC greater than 1.0 indicates a concentration greater than a benchmark. Organic (volatile organic compounds and pesticides) and special-interest (perchlorate) constituent RCs were classified as "high" (RC greater than $1.0)$, "moderate" ( $\mathrm{RC}$ less than or equal to 1.0 and greater than 0.1 ), or "low" (RC less than or equal to 0.1 ). For inorganic (radioactive, trace element, major ion, and nutrient) constituents, the boundary between low and moderate RCs was set at 0.5 .

Aquifer-scale proportion was used as the primary metric in the status assessment for evaluating groundwater quality at the study-unit scale or for its component areas. High aquifer-scale proportion was defined as the percentage of the area of the primary aquifer system with a RC greater than 1.0 for a particular constituent or class of constituents; the percentage is based on area rather than volume. Moderate and low aquifer-scale proportions were defined as the percentage of the primary aquifer system with moderate and low RCs, respectively. A spatially weighted statistical approach was used to evaluate aquifer-scale proportions for individual constituents and classes of constituents.

The status assessment for the Bear Valley study area found that inorganic constituents with health-based benchmarks were detected at high RCs in 9.0 percent of the primary aquifer system and at moderate RCs in 13 percent. The high RCs of inorganic constituents primarily reflected high aquifer-scale proportions of fluoride (in 5.4 percent of the primary aquifer system) and arsenic ( 3.6 percent). The RCs of organic constituents with health-based benchmarks were high in 1.0 percent of the primary aquifer system, moderate in 8.1 percent, and low in 70 percent. Organic constituents were detected in 79 percent of the primary aquifer system. Two groups of organic constituents and two individual organic constituents were detected at frequencies greater than 10 percent of samples from the USGS grid sites: trihalomethanes (THMs), solvents, methyl tert-butyl ether (MTBE), and simazine. The special-interest constituent perchlorate was detected in 93 percent of the primary aquifer system; it was detected at moderate RCs in 7.1 percent and at low RCs in 86 percent. 
The status assessment in the Lake Arrowhead Watershed study area showed that inorganic constituents with humanhealth benchmarks were detected at high RCs in 25 percent of the primary aquifer system and at moderate RCs in 41 percent. The high aquifer-scale proportion of inorganic constituents primarily reflected high aquifer-scale proportions of radon-222 (in 62 percent of the primary aquifer system) and uranium (26 percent). RCs of organic constituents with health-based benchmarks were moderate in 7.7 percent of the primary aquifer system and low in 46 percent. Organic constituents were detected in 54 percent of the primary aquifer system. The only organic constituents that were detected at frequencies greater than 10 percent of samples from the USGS grid sites were THMs. Perchlorate was detected in 62 percent of the primary aquifer system at uniformly low RCs.

The second component of this study, the understanding assessment, identified the natural and human factors that could have affected the groundwater quality in the BEAR study unit by evaluating statistical correlations between water-quality constituents and potential explanatory factors. The potential explanatory factors evaluated were land use (including density of septic tanks and leaking or formerly leaking underground fuel tanks), site type, aquifer lithology, well construction (well depth and depth to the top-of-perforated interval), elevation, aridity index, groundwater-age distribution, and oxidationreduction condition (including $\mathrm{pH}$ and dissolved oxygen concentration). Results of the statistical evaluations were used to explain the distribution of constituents in groundwater of the BEAR study unit.

In the Bear Valley study area, high and moderate RCs of fluoride were found in sites known to be influenced by hydrothermic conditions or that had high concentrations of fluoride historically. The high RC of arsenic can likely be attributed to desorption of arsenic from aquifer sediments saturated in old groundwater with high $\mathrm{pH}$ under reducing conditions. The THMs were detected more frequently at USGS grid sites that were wells, part of a large urban water system, and surrounded by urban land use. Solvents, MTBE, and simazine were all detected more frequently at USGS grid sites that were wells with a greater urban percentage of surrounding land use and that accessed older groundwater than other USGS grid sites. Comparison between the observed and predicted detection frequencies of perchlorate at USGS grid sites indicated that anthropogenic sources could have contributed to low levels of perchlorate in the groundwater of the Bear Valley study area.

In the Lake Arrowhead Watershed study area, high and moderate RCs of radon-222 and uranium can be attributed to older groundwater from the granitic fractured-rock primary aquifer system. Low RCs of THMs were detected at USGS grid sites that were wells and part of small water systems. The similarities between the observed and predicted detection frequencies of perchlorate in samples from USGS grid sites indicated that the source and distribution of perchlorate were most likely attributable to precipitation (rain and snow), with minimal, if any, contribution from anthropogenic sources.

\section{Introduction}

At times, groundwater can supply approximately half of the water used for public and domestic drinking-water in California (California Department of Water Resources, 2016). To assess the quality of ambient groundwater in aquifers used for drinking-water supply and to establish a baseline groundwater-quality monitoring program, the California State Water Resources Control Board (SWRCB), in collaboration with the U.S. Geological Survey (USGS) and Lawrence Livermore National Laboratory (LLNL), implemented the Groundwater Ambient Monitoring and Assessment (GAMA) Program (http://www.waterboards.ca.gov/gama/). The SWRCB initiated the GAMA Program in 2000 in response to Legislative mandates (State of California, 1999, 2001a). The program consists of four projects: (1) the GAMA Priority Basin Project (GAMA-PBP), carried out by the USGS (http:// ca.water.usgs.gov/gama/); (2) the GAMA Domestic Well Project, carried out by the SWRCB; (3) the GAMA Special Studies Project, carried out by LLNL; and (4) the GeoTracker GAMA online groundwater information system, led by the SWRCB (http://geotracker.waterboards.ca.gov/gama/). The SWRCB's GAMA Domestic Well Project sampled private domestic wells on a voluntary, first-come-first-served basis in six counties between 2002 and 2011. The GAMA-PBP was initiated in response to the Groundwater Quality Monitoring Act of 2001 to assess and monitor the quality of groundwater in California, to improve identification and understanding of risks to groundwater resources, and to increase the availability of information about groundwater quality to the public (State of California, 2001b). For the GAMA-PBP, the USGS, or USGS-GAMA, in cooperation with the SWRCB, developed and implemented a study design to monitor and assess groundwater basins through statistically reliable sampling approaches (Belitz and others, 2003; California State Water Resources Control Board, 2003).

From 2004 through 2012, the GAMA-PBP assessed water quality of groundwater resources used for public drinking water. The 35 study units sampled in this first phase represented more than 95 percent of the groundwater resources used for public-supply statewide (Belitz and others, 2015). Groundwater basins and areas outside of basins were prioritized for sampling primarily on the basis of the distribution of wells listed in the State of California's database of public-supply wells. (The California Department of Public Health Drinking Water Program that regulated water quality in public-supply wells was transferred to the SWRCB Division of Drinking Water, or SWRCB-DDW, on July 1, 2014.).

The ranges of hydrologic, geologic, and climatic conditions in California were considered in this statewide assessment of groundwater quality. Belitz and others (2003) partitioned the state into 10 hydrogeologic provinces, each with distinctive hydrologic, geologic, and climatic characteristics (fig. 1A). These hydrogeologic provinces include groundwater basins designated by the CDWR (California Department of Water Resources, 2003). 
Groundwater basins in California generally consist of relatively permeable, unconsolidated deposits of alluvial origin. Of California's approximately 16,000 active or standby public-supply wells or public-supply springs listed in the statewide water-quality database maintained by the SWRCB (SWRCB-DDW sites), 80 percent are in CDWR-designated groundwater basins (Belitz and others, 2003). Twenty percent of the SWRCB-DDW sites are in areas composed of igneous, metamorphic, or volcanic rocks, rather than in alluvial basins. Groundwater basins were prioritized for sampling on the basis of the number of SWRCB-DDW sites in the basin, with secondary consideration given to municipal groundwater use, agricultural pumping, the number of historically leaking underground fuel tanks, and the number of square-mile $\left(\mathrm{mi}^{2}\right)$ sections with registered pesticide applications (Belitz and others, 2003). Of the 472 CDWR-designated basins, 116 basins contain approximately 95 percent of SWRCBDDW sites in the CDWR-designated groundwater basins and were defined as "priority" basins (Belitz and others, 2003). The remaining 356 basins were defined as "lowuse" basins. All of the priority basins, selected low-use basins, and selected areas outside of basins were grouped into 35 GAMA-PBP study units that, together, represent approximately 95 percent of all SWRCB-DDW sites. The Bear Valley and Lake Arrowhead Watershed (BEAR) study unit is in the Transverse Ranges and Selected Peninsular Ranges hydrogeologic province (fig. $1 A$ ) and is composed of one priority groundwater basin and the USGS-defined Lake Arrowhead Watershed area near the Bear Valley groundwater basin (fig. 1B).

The GAMA-PBP was designed to assess the status of the quality of the groundwater resources, identify natural and human factors likely affecting groundwater quality, and monitor changes in groundwater quality. These three objectives were modeled after those of the USGS National Water Quality Assessment (NAWQA) Program (Hirsch and others, 1988). The sample collection protocols used in this study were designed to obtain representative samples of groundwater. The quality of groundwater can differ from the quality of drinking water because water chemistry can change as a result of contact with plumbing systems or with the atmosphere or because of treatment, disinfection, or blending with water from other sources. The assessments are intended to characterize the quality of groundwater in the primary aquifer system of the study unit, not the treated drinking water delivered to consumers by water purveyors. The primary aquifer system for a study unit is defined by the depths of the perforation or open intervals of the wells listed in the SWRCB-DDW water-quality database for the study unit. The SWRCB-DDW water-quality database lists wells and springs used for public drinking-water supplies (from systems that serve 25 or more people or have 15 or more connections) and includes wells and springs from systems classified as "community" (such as those in cities, towns, and mobile home parks), "non-transient, non-community" (such as those in schools, workplaces, and restaurants), or "transient, non-community" (such as those in campground, and parks; California State Water Resources Control Board, 2015).

This USGS scientific investigations report (SIR) is similar to other USGS SIRs written for the GAMA-PBP study units sampled to date and is the second in a series of reports presenting the water-quality results for the BEAR study unit. Reports addressing the status, understanding, and trends aspects of the water-quality assessments done by the GAMAPBP are available from the USGS (http://ca.water.usgs.gov/ gama/includes/GAMA_publications.html) and the SWRCB (http://www.swrcb.ca.gov/gama/).

The purposes of this report are to (1) describe the hydrogeologic setting of the BEAR study unit, (2) assess the status of groundwater quality in the primary aquifer system in the BEAR study unit, (3) generally identify the natural and anthropogenic factors that could be affecting groundwater quality, and (4) discuss correlations between water quality and selected explanatory factors. Characteristics of groundwater resources used for drinking water, including overlying land-use characteristics, well depth and hydrologic conditions, geologic characteristics, and groundwater age and geochemical conditions, are described by using ancillary data compiled for the groundwater sites sampled by USGS-GAMA for the BEAR study unit.

The status assessment is designed to provide a spatially balanced assessment of the quality of groundwater resources used for public drinking water at the study-area scale for the period of the assessment (Belitz and others, 2003, 2010, 2015). This report describes methods used to design the sampling network for the status assessment and to estimate aquifer-scale proportions for specified ranges of constituent concentrations (Belitz and others, 2010). Aquifer-scale proportion is defined as the areal proportion of the groundwater resource having groundwater of a defined quality (Belitz and others, 2010). Water-quality data from 27 sites sampled by USGS-GAMA for the BEAR study unit (Mathany and Belitz, 2013) were used for the status assessment. Aquifer-scale proportions for constituents and classes of constituents were computed for the two study areas in the BEAR study unit by using a spatially balanced, areally weighted method (Belitz and others, 2010, 2015).

The assessments in this report characterize the quality of untreated groundwater resources in the primary aquifer system in the study unit, not the drinking water delivered to consumers by water purveyors. Regulatory benchmarks apply to drinking water that is delivered to the consumer, not to untreated groundwater. To provide context, however, the water-quality data discussed in this report were compared to California and Federal regulatory and non-regulatory benchmarks for treated drinking water delivered by public water systems. These groundwater-quality comparisons are presented in terms of relative concentrations (RCs), which are defined as a ratio; that is, the $\mathrm{RC}$ is calculated by dividing the concentration of a constituent in groundwater by the concentration of the benchmark for that constituent. 
A

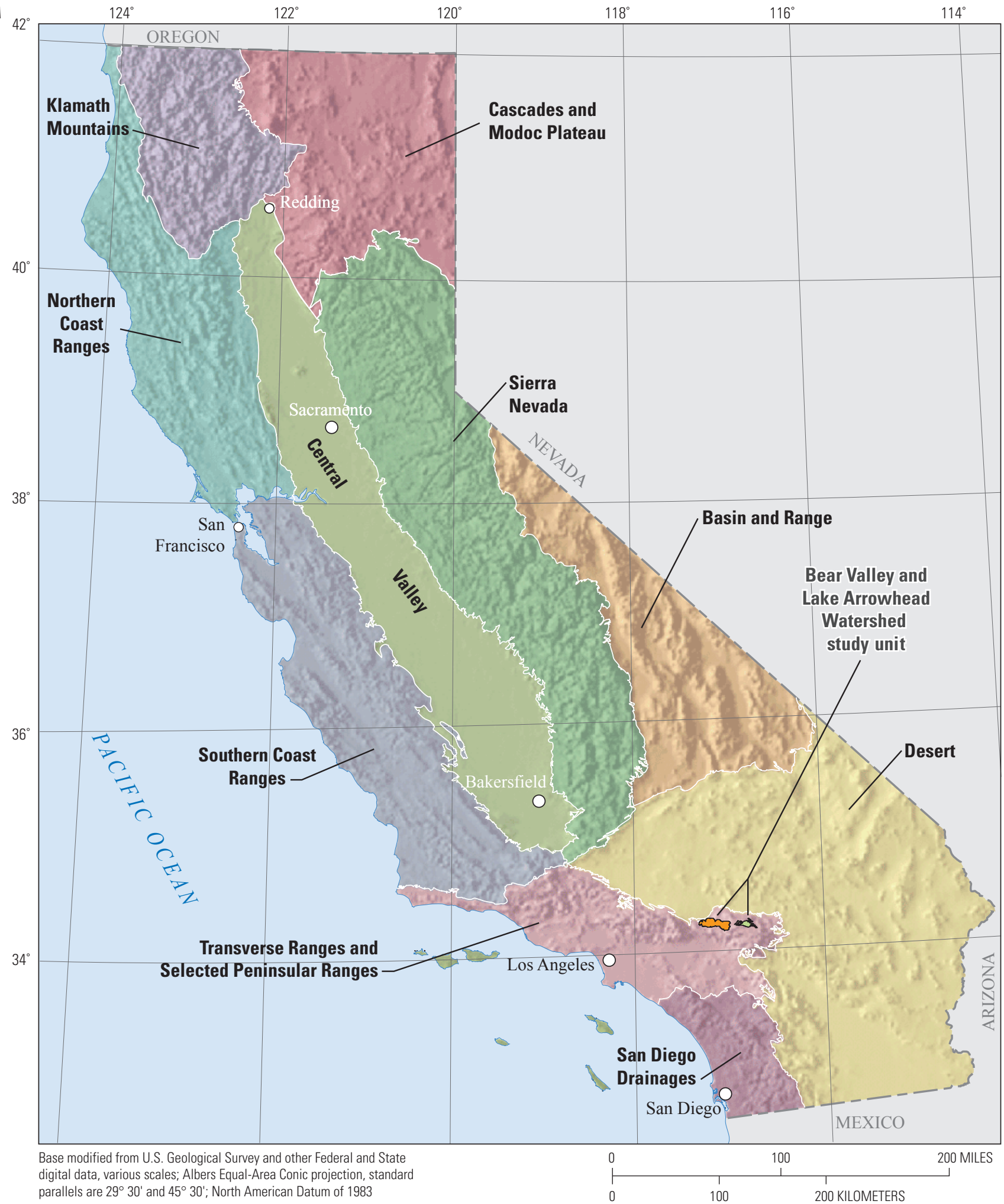

Figure 1. California hydrogeologic provinces and location of selected study areas of the California Priority Basin Project, specifically, $A$, the Bear Valley and Lake Arrowhead Watershed study unit and $B$, the Bear Valley and Lake Arrowhead Watershed study areas. 


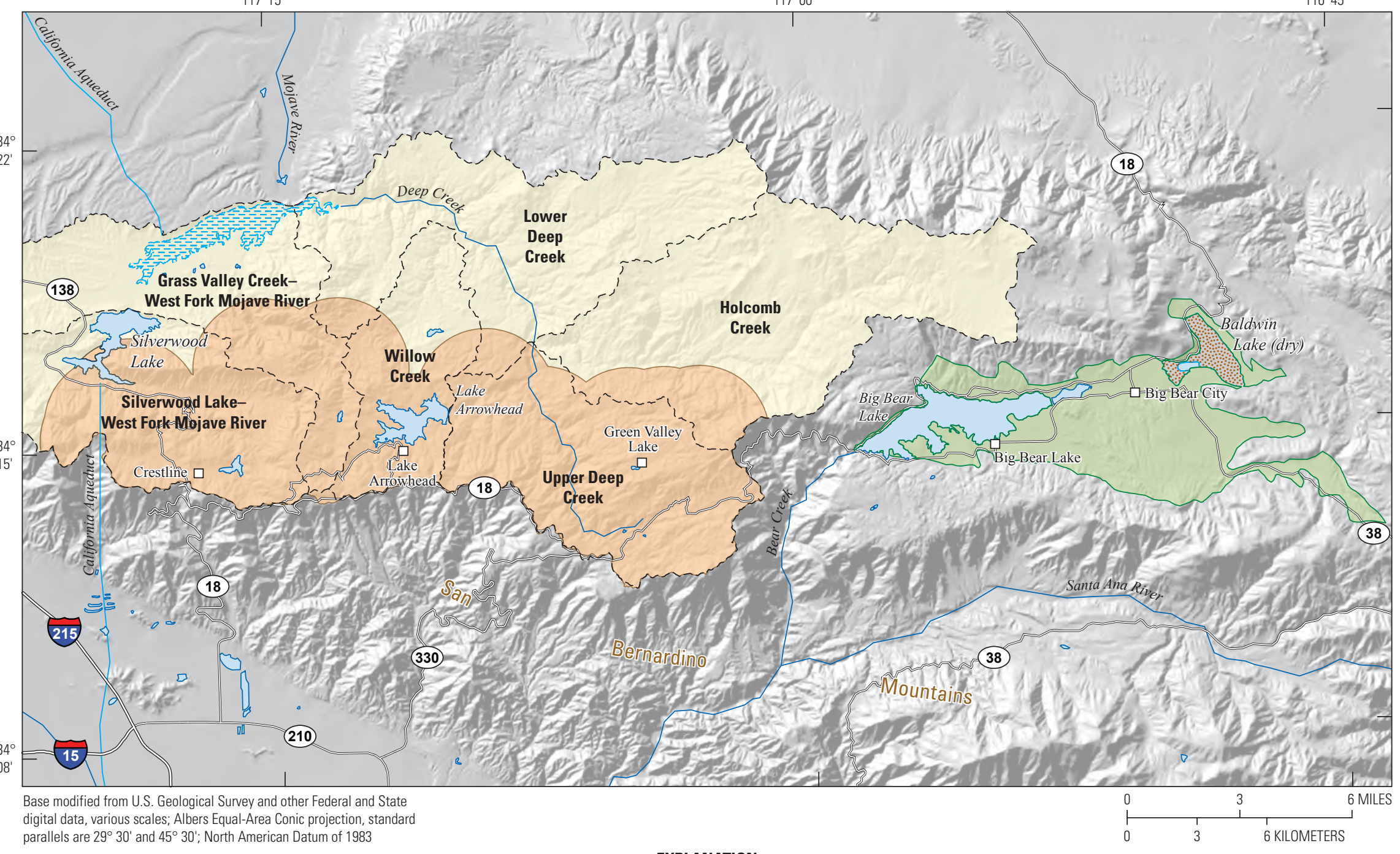

\section{EXPLANATION}

Bear Valley study area

Lake Arrowhead Watershed study area
[Willow Watershed subbasin and identifier

(U.S. Department of Agriculture, 2013)

Inundation area

Figure 1. - Continued 
The understanding assessment was based on waterquality data from 38 sites - the 27 assessment sites and 11 understanding sites sampled by the USGS for the GAMA Program. The SWRCB-DDW sites were not used because data for many of the potential explanatory factors were not available; in particular, data for age-dating tracers, dissolved oxygen, well depth, and depth to the top-of-perforation interval are not maintained in the SWRCB-DDW waterquality database.

\section{Hydrogeologic Setting}

The BEAR study unit is in the eastern part of the San Bernardino Mountains in southern California and covers $112 \mathrm{mi}^{2}$ in San Bernardino County, California. The BEAR study unit includes two study areas: the CDWR-defined Bear Valley groundwater basin (California Department of Water Resources, 2003) and the USGS-defined Lake Arrowhead Watershed (fig. 1B).

The climate in the BEAR study unit is typical of mountainous areas in southern California, with warm summers and cold winters (PRISM Climate Group, 2012. General precipitation distribution in the study unit reflects a rain-shadow effect from west to east due to the mountains that separate the two study areas (fig. $1 B$ ). Average annual precipitation in the Lake Arrowhead Watershed study area (82 inches per year, or in/yr) is greater than in the Bear Valley study area (72 in/yr), but because of the higher elevation, average annual snow accumulation is greater in the Bear Valley study area. Average annual precipitation in the Lake Arrowhead Watershed study area mostly (58 percent) falls as snow, but 75 percent on average in the Bear Valley study area falls as snow (PRISM Climate Group, 2012; U.S. Department of Commerce, 2011; Western Regional Climate Center, 2011; Flint and Martin, 2012).

\section{BEAR Study Unit-Bear Valley Study Area}

The Bear Valley (BV) study area coincides with the $30.6 \mathrm{mi}^{2}$ valley delimited by the CDWR as its Bear Valley groundwater basin (California Department of Water Resources, 2004). The Bear Valley groundwater basin is an east-west trending alluvial valley containing Big Bear and Baldwin Lakes at the base of a north-facing slope of the San Bernardino Mountains (California Department of Water Resources, 2004; fig. 2A). The boundaries of the study area are defined by the Quaternary alluvial sediments of the Bear Valley groundwater basin (California Department of Water Resources, 2004; fig. 3A).

The BV study area is surrounded by the San Bernardino Mountains and elevations range from approximately 6,700 feet (ft) on the valley floor to over 10,200 ft on the southern boundary. Two lakes - Big Bear and Baldwin — are the major surface-water features in the study area. Big Bear Lake is a man-made lake used for public recreation as well as a water supply for the San Bernardino area (Big Bear Municipal Water
District, 2011). The lake is fed by runoff from numerous creeks that drain the surrounding mountains and valley floor. Baldwin Lake is usually dry, receiving only occasional runoff from the surrounding mountains. The only notable surfacewater outflow from any of the lakes is from Big Bear Lake to the west through the Bear Valley Dam and into Bear Creek, which flows into the Santa Ana River 8 miles (mi) to the south (Flint and Martin, 2012; fig. 1B).

The primary aquifer system in the BV study area is in the upper and middle aquifers of an interconnected three-tiered alluvial aquifer system of Holocene age that is underlain by basement rocks, mapped on figure $3 A$ as sedimentary deposits (California Department of Water Resources, 2004; Flint and Martin, 2012). Gravity-model results indicated that the alluvial deposits range from less than $500 \mathrm{ft}$ thick on the edges of the study area and on the eastern end of Big Bear Lake to more than 1,500 $\mathrm{ft}$ thick beneath the center of Big Bear Lake and to the west of Baldwin Lake (Flint and Martin, 2012). The basement rocks are of pre-Tertiary age and are made up of large granitic bodies and, to a lesser extent, metamorphosed sedimentary rocks and gneiss. Fractured basement rock is known to make a small contribution to groundwater resources along the southern part of the study area (California Department of Water Resources, 2004).

The upper aquifer-which contributes water to wells along the edges of the BV study area-is composed of unconsolidated gravel and sand deposits, which transmit groundwater readily. This aquifer is thin and unsaturated in the western part of the study area, but in the eastern part of the study area, its thickness exceeds $200 \mathrm{ft}$ (California Department of Water Resources, 2004; Flint and Martin, 2012). The middle aquifer consists of alluvial fan deposits and other alluvium made up of various amounts of silt, gravel, sand, and clay. This aquifer is found throughout the study area and ranges from $150 \mathrm{ft}$ to more than $800 \mathrm{ft}$ thick. Groundwater in the alluvial sediments of the middle aquifer is generally confined under a layer of silts and clays - up to $50 \mathrm{ft}$ thick in some areas - whereas groundwater in fan deposits is generally unconfined to semi-confined (California Department of Water Resources, 2004; Flint and Martin, 2012).

Groundwater in the BV study area generally flows from the sides of the Bear Valley groundwater basin toward Big Bear or Baldwin Lakes, following the topography of the valley. A groundwater divide is present between Big Bear Lake and Baldwin Lake near Big Bear City. Various faults could act as hydrologic barriers to groundwater movement in the study area (California Department of Water Resources, 2004).

In the BV study area, groundwater is recharged by direct percolation of precipitation, infiltration of run-off from the surrounding mountains, and underflow from fractured metamorphic and granitic basement rocks (California Department of Water Resources, 2004; GEOSCIENCE Support Services, Inc., 2006; Flint and Martin, 2012). Where present, the permeable, younger alluvium allows rapid infiltration of rainfall and snowmelt runoff (GEOSCIENCE Support Services, Inc., 2006; Flint and Martin, 2012). 
A

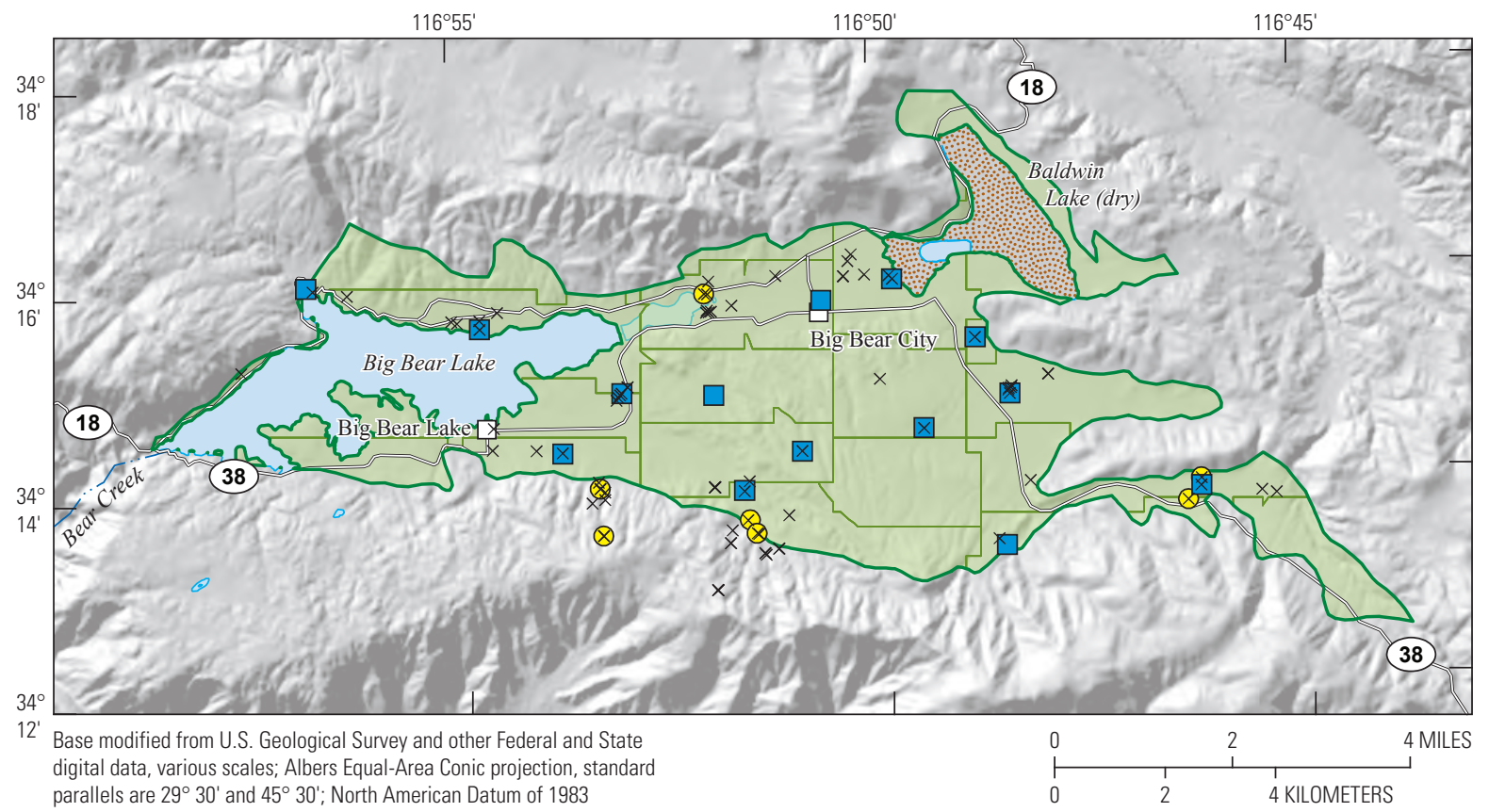

EXPLANATION

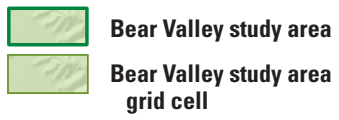

$\square \quad$ U.S. Geological Survey (USGS) grid site

$\times$ California State Water Resources Control Board grid cell

$\bigcirc$ USGS understanding site Division of Drinking Water site

B

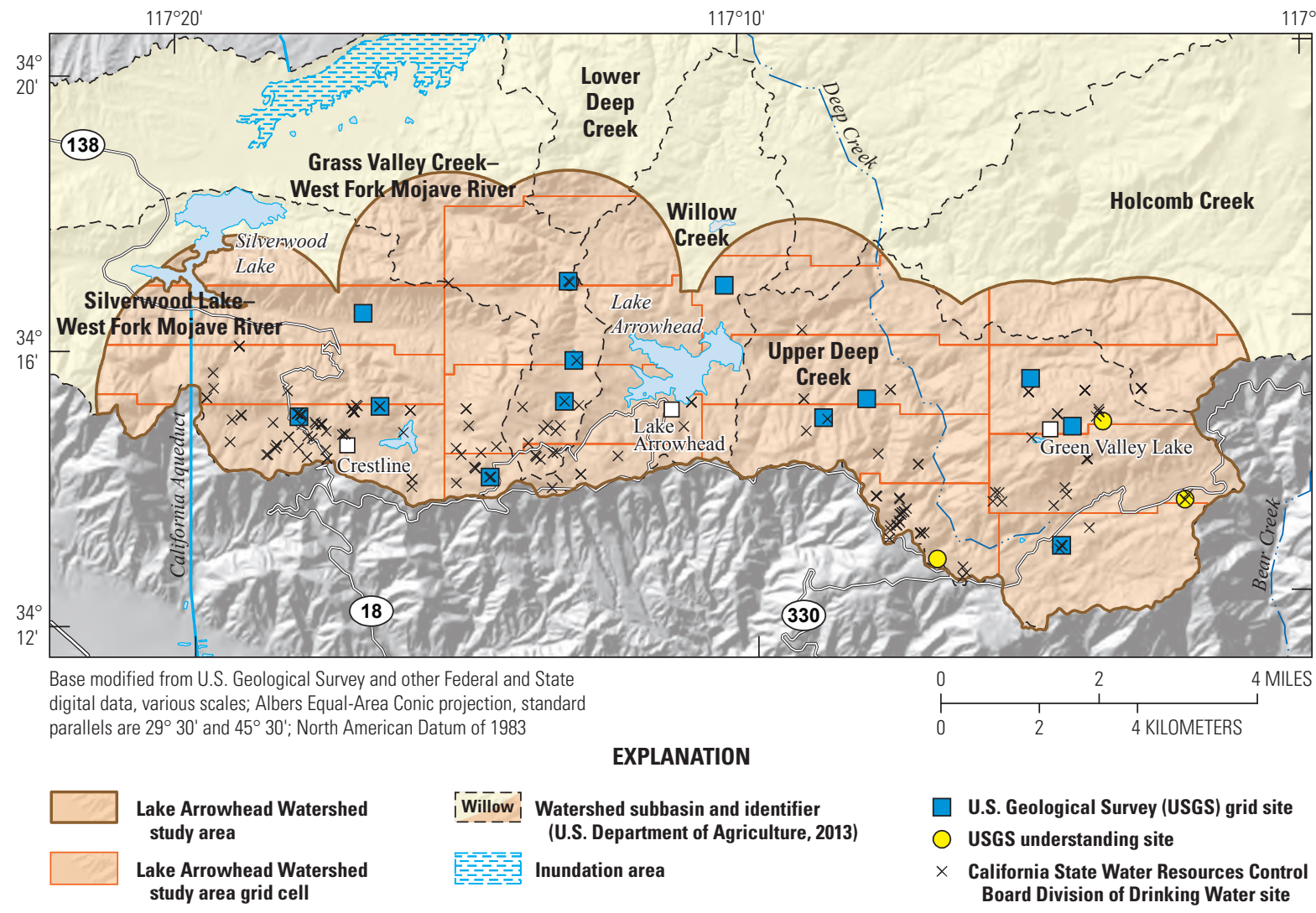

Figure 2. Study area, grid cells, U.S. Geological Survey (USGS) grid and understanding sites, and California Division of Drinking Water (SWRCB-DDW) sites in the study areas of the Bear Valley and Lake Arrowhead Watershed study unit, California Groundwater Ambient Monitoring and Assessment (GAMA) Priority Basin Project: $A$, Bear Valley and $B$, Lake Arrowhead Watershed. 
$\boldsymbol{A}$

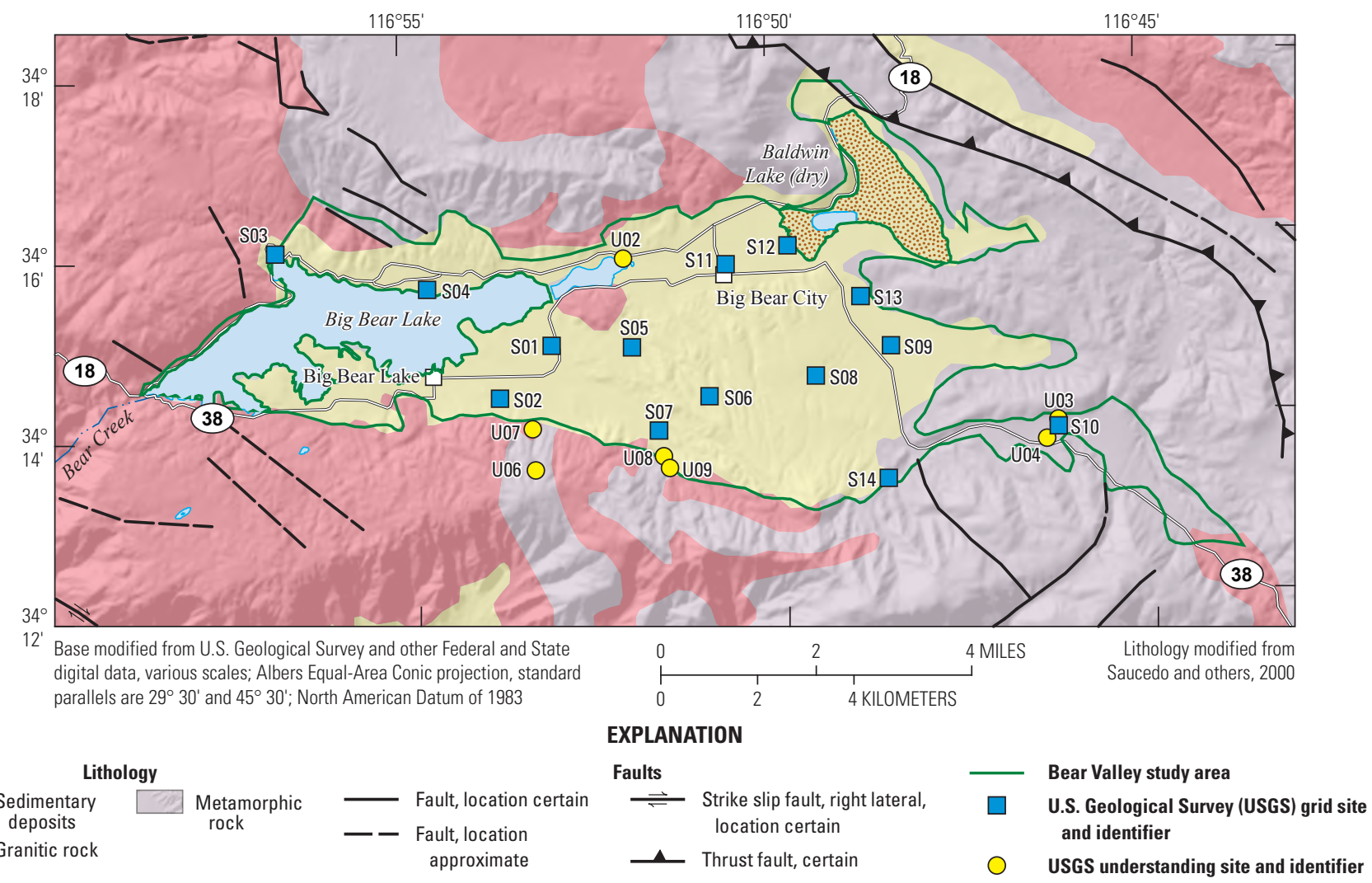

B

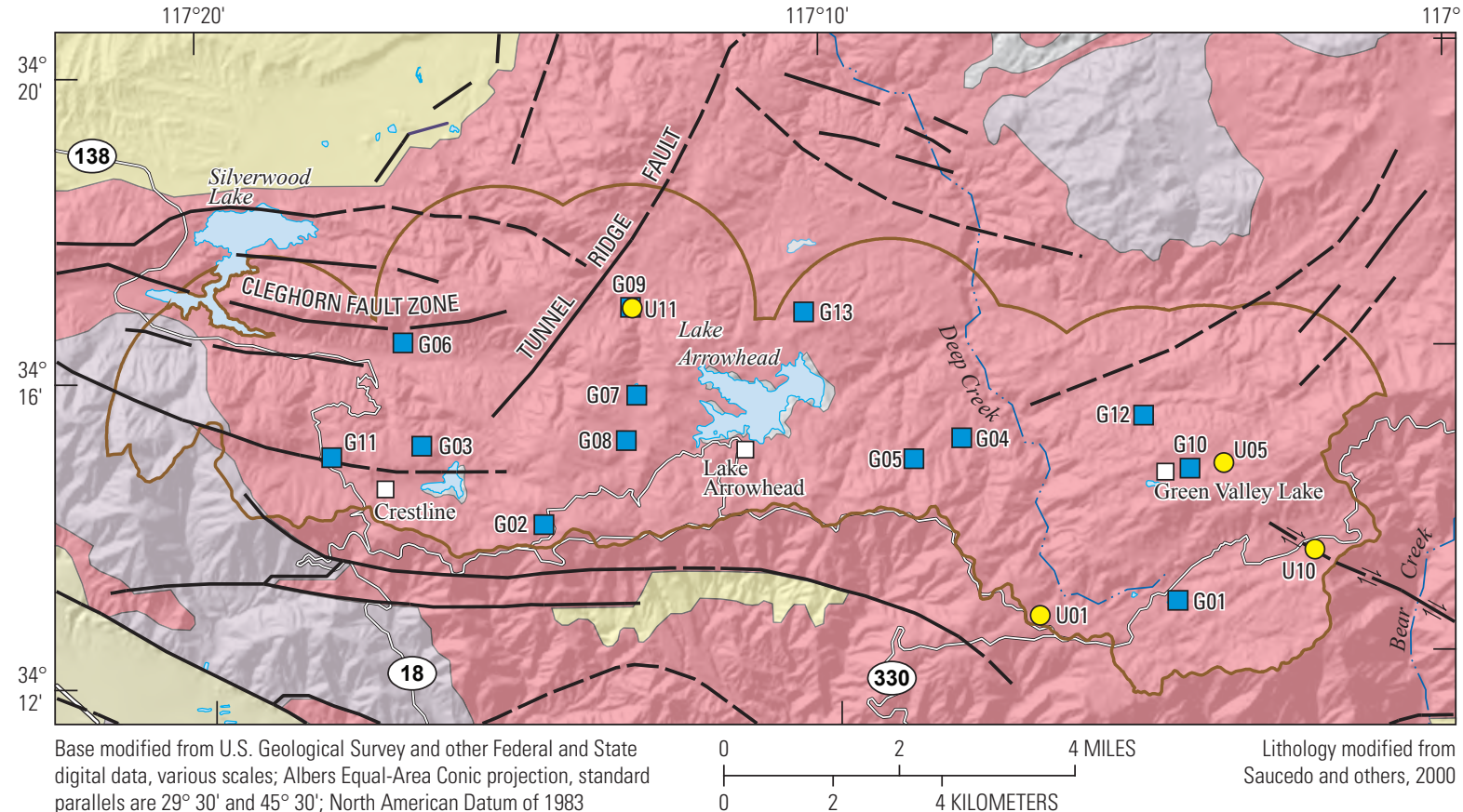
parallels are $29^{\circ} 30^{\prime}$ and $45^{\circ} 30^{\prime}$; North American Datum of 1983

\section{EXPLANATION}

Faults

$$
\begin{aligned}
& \text { Sedimentary } \square \text { Metamorphic } \square \text { Fault, location certain } \\
& \text { deposits }
\end{aligned}
$$

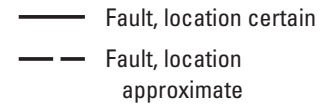
$\rightleftharpoons$ Strike slip fault, right lateral, location certain
—- Strike slip fault, right lateral, location approximate

$117^{\circ}$

Figure 3. Geology and U.S. Geological Survey (USGS)-sampled sites in the study areas of the Bear Valley and Lake Arrowhead Watershed study unit, California Groundwater Ambient Monitoring and Assessment (GAMA) Priority Basin Project: $A$, Bear Valley and $B$, Lake Arrowhead Watershed. 


\section{BEAR Study Unit-Lake Arrowhead Watershed Study Area}

The Lake Arrowhead Watershed (LAW) study area is $81.5 \mathrm{mi}^{2}$ in area (fig. $2 \mathrm{~B}$ ), is approximately $3 \mathrm{mi}$ west of the BV study area, and includes a mostly granitic bedrock area surrounding Lake Arrowhead (fig. 3B). The San Bernardino Mountains separate the LAW study area from the BV study area. The LAW study area includes parts of six watersheds on the north-facing slope of the San Bernardino Mountains: Silverwood Lake-West Fork Mojave River, Grass Valley Creek-West Fork Mojave River, Willow Creek, Upper Deep Creek, Lower Deep Creek, and Holcomb Creek (U.S. Department of Agriculture, 2013). The study area was defined as those parts of the six watersheds in any of the 1.86-mi radial buffers around the SWRCB-DDW sites in those watersheds (fig. 2B). The collective area of these buffers, as masked by the watershed extent, deliminated the LAW study area.

Elevations in the LAW study area range from approximately 3,200 ft near Silverwood Lake in the western part of the study area to more than $7,800 \mathrm{ft}$ in the San Bernardino Mountains. Two man-made lakes-Arrowhead and Silverwood - are the largest surface-water features in the study area. Lake Arrowhead, which provides water to the local community sharing its name and the San Bernardino area, is also a private recreational facility (Arrowhead Lake Association, 2011; Lake Arrowhead Community Services District, 2011a). Silverwood Lake was created as part of the California State Water Project and is a water source for communities inside and outside of the study area (California Department of Water Resources, 2011a, b).

The primary aquifer system in the LAW study area consists of fractured granite bedrock and is considered to be confined to semi-confined (fig. $3 B$ ). In the Lake Arrowhead area, the granitic fractured-rock aquifer is known to extend to a depth of $500 \mathrm{ft}$ (GEOSCIENCE Support Services, Inc., 2008). In addition to the production wells that are drilled and screened in the granitic bedrock, numerous springs and horizontal wells are major sources of water in the study area that flow under artesian conditions for all or most of the year (GEOSCIENCE Support Services, Inc., 2008; Lake Arrowhead Community Services District, 2011b). Throughout the study area, a thin layer of alluvial deposits derived from weathering and erosion of the surrounding mountains overlies the granitic bedrock (GEOSCIENCE Support Services, Inc., 2008).

Groundwater in the LAW study area moves through numerous fracture systems related to local and regional faults (fig. 3B). The largest of these is the Cleghorn fault zone, which is in the western part of the study area (Bryant, 2003). The Tunnel Ridge fault (also known as the Tunnel Ridge lineament) is a major northeast-trending fault that is known to transport groundwater in the northern and central parts of the study area (Bryant, 1987). There are also unnamed northeast-trending faults in the northeastern part of the study area (fig. 3B), but the effect of these faults on groundwater movement is not known.

Groundwater in the LAW study area is recharged by rainfall and snowmelt runoff that penetrates the granitic bedrock through faults and fractures chiefly at high elevations in the surrounding mountains (Lake Arrowhead Community Services District, 2011b). Groundwater recharge in the LAW study area also is most likely affected by the thin layer of alluvial deposits that overlay the primary aquifer system (GEOSCIENCE Support Services, Inc., 2008).

\section{Methods}

This section describes the methods used for the status assessment and understanding assessment of water quality in the BEAR study unit. Methods used to collect and analyze groundwater samples were described, and results for the evaluation of quality-control data were presented, by Mathany and Belitz (2013).

\section{Status Assessment}

The status assessment was designed to provide a quantitative summary of groundwater quality in the primary aquifer systems of the BEAR study unit. The primary aquifer system is defined as the part of the aquifer system that is used for public drinking-water supplies. In groundwater basins, the depth of the primary aquifer system is defined by the depth intervals in which public supply wells are screened or open. In many areas with fractured-bedrock aquifers, the depth of the primary aquifer system is not easily defined because some groundwater sources for public supply are springs rather than wells. This section describes the methods used for (1) defining groundwater quality, (2) assembling the data used for the assessment, (3) selecting constituents for evaluation, and (4) calculating aquifer-scale proportions.

\section{Groundwater Quality Defined as Relative Concentrations}

In this study, groundwater-quality data are presented as RCs. An RC is defined as the ratio of a constituent's concentration measured in a groundwater sample to the concentration of a constituent's regulatory or non-regulatory benchmark used to evaluate drinking-water quality. The use of RCs is similar to approaches employed by other studies to place the concentrations of constituents in groundwater in a toxicological context (for example, U.S. Environmental Protection Agency, 1986; Toccalino and others, 2004; Toccalino and Norman, 2006; Rowe and others, 2007).

Detailed descriptions of the methods used by the GAMA Program to derive, categorize, and apply RCs can be found in previous USGS SIRs written for the GAMA-PBP (http:// ca.water.usgs.gov/gama/includes/GAMA_publications.html). 
Briefly, an RC value less than 1 indicates that the sample concentration was less than the benchmark concentration, and an $\mathrm{RC}$ value greater than 1 indicates that the sample concentration was greater than the benchmark concentration. The use of RCs permits comparison on a single scale for constituents that can be present at a wide range of concentrations. An RC can only be computed for constituents with water-quality benchmarks; therefore, constituents without water-quality benchmarks were not included in the status assessment.

Regulatory and non-regulatory benchmarks apply to treated water that is served to the consumer by public-supply water systems, not to untreated groundwater. To provide some context for the results, however, concentrations of constituents measured in the untreated groundwater were compared to benchmarks established by the U.S. Environmental Protection Agency (EPA), SWRCB-DDW, and USGS. The benchmarks used for each constituent were selected in the following order of priority:

1. Regulatory, health-based levels established by the SWRCB-DDW and the EPA: SWRCB-DDW and EPA maximum contaminant levels (MCL-CA and MCL-US, respectively) and EPA action levels (AL-US; California State Water Resources Control Board, 2015; U.S. Environmental Protection Agency, 2006).

2. Non-regulatory, health-based levels established by USGS, EPA, and SWRCB-DDW: USGS healthbased screening levels (HBSL), EPA lifetime health advisory levels (HAL-US), EPA risk-specific doses for 1:100,000 risk factor (RSD5-US), and SWRCBDDW notification levels (NL-CA; U.S Environmental Protection Agency, 2013; Toccalino and others, 2014; California State Water Resources Control Board, 2015).

3. Non-regulatory aesthetic-based levels established by SWRCB-DDW: secondary maximum contaminant levels (SMCL-CA; California State Water Resources Control Board, 2015). The salinity indicators chloride, sulfate, and total dissolved solids (TDS) have recommended and upper SMCL-CA levels, and the values for the upper levels were used.

For constituents with multiple types of benchmarks, this hierarchy does not necessarily result in selection of the benchmark with the lowest concentration. Additional information on the types of benchmarks and listings of the benchmarks for all constituents analyzed is provided by Mathany and Belitz (2013).

Toccalino and others (2004), Toccalino and Norman (2006), and Rowe and others (2007) used the ratio of measured sample concentration to the benchmark concentration, either MCL-US or HBSL, and defined this ratio as the benchmark quotient (BQ). The term $\mathrm{RC}$ is used in this report rather than $\mathrm{BQ}$ because these 2 benchmark values are not the same for the 20 constituents that have MCL-CA values that differ from their MCL-US values or for the 11 constituents that neither have MCL-US nor HBSL values.

For ease of discussion, RCs of constituents were classified into low, moderate, and high categories. The $\mathrm{RC}$ values greater than 1.0 were defined as "high" for all constituents. For inorganic constituents (trace elements, nutrients, radioactive constituents, and inorganic constituents having SMCL benchmarks), an RC greater than 0.5 and less than or equal to 1.0 was defined as "moderate," and an RC less than or equal to 0.5 was defined as "low." For organic and special-interest constituents, 0.1 was the bounding RC value between the "moderate" and "low" categories. Although more complex classifications could be devised on the basis of properties and sources of individual constituents, use of a single moderate/low threshold value for each of the two major groups of constituents provided consistent objective criteria for distinguishing constituents present at moderate, rather than low, concentrations.

\section{Datasets Used for Status Assessment}

Groundwater-quality data used for the status assessment came from sites sampled by the USGS and from the SWRCBDDW water-quality database. Data from the USGS-sampled sites and SWRCB-DDW sites (not sampled by the USGS) were used for calculating RCs and for the areally weighted approach to aquifer-scale proportions. This section explains how each dataset was assembled.

\section{U.S. Geological Survey Randomized Sites}

Detailed descriptions of the stratified-random sampling design used to identify groundwater sites for grid-based sampling are given in Mathany and Belitz (2013). Briefly, the BEAR study unit was divided into two study areas, the Bear Valley and the Lake Arrowhead Watershed, with each study area being stratified into a grid of 15 equal-area cells (Scott, 1990). In each of the 30 cells, one existing groundwater site was randomly selected to represent the groundwater resource used for public supply in the cell (figs. $2 A, B$ ). The existing sites in the BEAR study unit primarily were 69 public-supply sites in the SWRCB-DDW water-quality database, and these were each assigned random rankings. In each cell, the highest ranked site that met basic sampling requirements and for which permission could be obtained was sampled and is called a "grid site". For cells without accessible public-supply sites, appropriate sites were selected from the USGS Groundwater Site Inventory (GWSI) database. The USGS sampled sites in 27 of the 30 grid cells; 3 cells were dropped from the study because no accessible sites were found or the sites did not meet the basic requirements. Of these 27 USGS grid sites, 25 were listed in the SWRCB-DDW water-quality database. 
USGS grid sites were named with an alphanumeric GAMA ID consisting of a prefix identifying the study area and a number indicating the order of sample collection (fig. 3). The following prefixes were used to identify the study area: "S" for the BV study area, because the coincident groundwater basin was defined by the extent of sedimentary deposits (California Department of Water Resources, 2004), and "G" for the LAW study area, because the primary aquifer system consists of fractured granitic rocks. Of the 27 USGS grid sites sampled, 7 were springs, and 20 were wells (appendix table 1-2).

Samples collected from USGS grid sites were analyzed for 233 constituents (table 1). Water-quality data collected by USGS-GAMA are tabulated in Mathany and Belitz (2013) and also are available from the SWRCB's publically accessible internet database GeoTracker GAMA (http://www. waterboards.ca.gov/gama/geotracker_gama.shtml) and the USGS's publically accessible internet database NWISWeb (http://waterdata.usgs.gov/ca/nwis/).

\section{U.S. Geological Survey Non-Randomized Sites}

Eleven non-randomized sites were sampled to help understand potential groundwater-quality issues associated with ski-area land use and historical and more recent septictank use. These samples and sites were given identifiers including the letter "U" to distinguish these as belonging to the set of sampled sites referred to as USGS understanding sites (Mathany and others, 2013; figs. 3A, B). Of the 11 USGS understanding sites, 7 were public-supply sites that were listed in the SWRCB-DDW water-quality database, and 4 were listed in the USGS-GWSI database. Six of the USGS understanding sites were wells, and five were springs (appendix table 1-2).

The water-quality results from the USGS understanding sites showed minimal detections of the constituents that were chosen as potential indicators of ski-area land use (wastewater indicator compounds) and septic-tank use (pharmaceutical compounds; Mathany and Belitz, 2013). Water-quality results from the USGS understanding sites are used in this report, where applicable, to aid in the understanding assessment of the constituents of concern that were identified in the status assessment.

\section{California Division of Drinking Water (SWRCB- DDW) Dataset}

In addition to USGS data, the areally weighted calculations of aquifer-scale proportions included waterquality data collected by the SWRCB-DDW during the 3 years from April 1, 2007, to April 1, 2010, at 86 sites. For 20 of these sites, USGS-GAMA data (15 USGS grid sites and 5 USGS understanding sites) and SWRCB-DDW data were both available, but only the USGS-GAMA data were used. The SWRCB-DDW data available for many of the 86 sites were from samples with only a limited number of constituents analyzed. For example, nitrate data were available for 78 sites, but data for at least 1 trace element were only available for 58 sites. Water-quality data collected by the SWRCB-DDW are available from the SWRCB's publically accessible internet database, GeoTracker GAMA (http://www.waterboards. ca.gov/gama/geotracker_gama.shtml).

Table 1. Summary of sites sampled and constituent groups analyzed by the U.S. Geological Survey, Bear Valley and Lake Arrowhead Watershed study unit, 2010, California Groundwater Ambient Monitoring and Assessment (GAMA) Priority Basin Project.

[C, carbon; H, hydrogen; He, helium; N, nitrogen; O, oxygen; Sr, strontium; $\delta$, delta notation, indicating the isotopic enrichment or depletion of a sample relative to a standard known composition]

\begin{tabular}{|c|c|}
\hline Site information & $\begin{array}{l}\text { Number of } \\
\text { sites sampled }\end{array}$ \\
\hline Grid sites & 27 \\
\hline Understanding sites & 11 \\
\hline Sum & 38 \\
\hline Constituent groups & $\begin{array}{l}\text { Number of } \\
\text { constituents }\end{array}$ \\
\hline \multicolumn{2}{|l|}{ Inorganic constituents } \\
\hline Trace elements & 23 \\
\hline Major and minor ions and total dissolved solids & 11 \\
\hline Alkalinity and specific conductance & 2 \\
\hline Nutrients and dissolved organic carbon & 6 \\
\hline Uranium and radon-222 & 2 \\
\hline \multicolumn{2}{|l|}{ Organic constituents } \\
\hline Volatile organic compounds & 85 \\
\hline Pesticides and pesticide degradates & 83 \\
\hline \multicolumn{2}{|l|}{ Special-interest constituents } \\
\hline Perchlorate & 1 \\
\hline 1,2,3-Trichloropropane (1,2,3-TCP) & 1 \\
\hline $\mathrm{N}$-Nitrosodimethylamine (NDMA) & 1 \\
\hline \multicolumn{2}{|c|}{ Geochemical and age-dating tracers } \\
\hline Dissolved oxygen, $\mathrm{pH}$, and temperature & 3 \\
\hline Tritium & 1 \\
\hline $\begin{array}{l}\text { Noble gases (helium, neon, argon, krypton, } \\
\text { xenon), }{ }^{3} \mathrm{He} /{ }^{4} \mathrm{He} \text { of helium, and tritium }\end{array}$ & 7 \\
\hline$\delta^{2} \mathrm{H}$ and $\delta^{18} \mathrm{O}$ in water & 2 \\
\hline$\delta^{15} \mathrm{~N}$ and $\delta^{18} \mathrm{O}$ in dissolved nitrate & 2 \\
\hline Strontium isotope ratio in water $\left({ }^{87} \mathrm{Sr} /{ }^{86} \mathrm{Sr}\right)$ & 1 \\
\hline Carbon-14 and $\delta^{13} \mathrm{C}$ of dissolved carbonates & 2 \\
\hline Sum & 233 \\
\hline
\end{tabular}




\section{Selection of Constituents for Discussion}

Of the 233 constituents analyzed in samples from the BEAR study unit (table 1), 123 had benchmarks and were therefore addressed in the status assessment. Aquiferscale proportions are presented for the subset of these 123 constituents that met the following criteria:

- Constituents present at high or moderate RCs at the USGS grid or understanding sites or for any sample collected between April 1, 2007, and April 1, 2010, in the SWRCB-DDW water-quality database.

- Organic constituent classes that have at least one constituent detected at more than 10 percent in the USGS grid sites in either the LAW or BV study areas.

These criteria identified nine inorganic constituents, one organic constituent class, eight organic constituents, and one special interest constituent (table 2). An additional 34 inorganic and 5 organic constituents were detected, but either have no benchmarks or only were detected at low RCs (table 3).

A review of the SWRCB-DDW water-quality database identified constituents for which RCs were high historically, starting with the earliest record maintained in the database and ending just before the status assessment, July 6, 1982March 31, 2007 (table 4). Constituents can be present at high concentrations during the historical period, but not during the study period (April 1, 2007-April 1, 2010), because of improved groundwater quality over time or because sites where concentrations were high were removed from the set used for public supply. Historically high concentrations of constituents in samples that did not meet the criteria for inclusion in the status assessment were not representative of groundwater quality in the BEAR study unit from 2007 to 2010.

In the BEAR study unit, there were nine constituents (gross beta particle activity; aluminum; thallium; vanadium; zinc; TDS; benzene; 1, 2-dichloroethane; and trihalomethanes (THMs) for which RCs were high during the historical period, but for which high RCs were not reported during the study period or in the USGS-GAMA dataset (table 4).

\section{Calculation of Aquifer-Scale Proportions}

A spatially weighted aquifer-scale statistical approach (Belitz and others, 2015) was used to evaluate the areal proportions of the primary aquifer system in the BEAR study unit with high, moderate, and low RCs of constituents. For ease of discussion, these proportions are referred to as high, moderate, and low aquifer-scale proportions. Calculations of aquifer-scale proportions were made for individual constituents as well as for classes of constituents. The classes consisted of groups of related individual constituents.

The aquifer-scale calculation was done using the dataset assembled from all the SWRCB-DDW and USGS grid and understanding sites. For each constituent, the high aquiferscale proportion was calculated by computing the proportion of sites in each cell with one or more high RCs and then averaging the proportions for all cells (Isaaks and Srivastava, 1989; Belitz and others, 2010). The moderate aquifer-scale proportion was calculated similarly. For calculation of the high aquifer-scale proportion for a class of constituents, procedures differed slightly. The site was considered to have a high RC if any of the constituents in that class had a high $\mathrm{RC}$. The site was considered to have a moderate RC if any of the constituents in the class had a moderate RC, but none had a high RC. After these adjustments for classes of constituents were completed at the site scale, calculations of the cell-scale proportion and aquifer-scale proportion were the same as for individual constituents. In addition, for each constituent, the raw detection frequencies of high and moderate RCs for individual constituents were calculated using the same dataset as used for the spatially weighted calculations.

\section{Understanding Assessment}

The understanding assessment was designed to evaluate natural and anthropogenic factors that can affect groundwater quality. A finite set of potential explanatory factors was considered: land use, density of septic tanks and leaking or formerly leaking underground fuel tanks (LUFTs), aquifer lithology classification, well construction (including well depth and depth to the top of the perforated interval in the well), site type, groundwater age, elevation, aridity index, oxidation-reduction conditions (redox), dissolved oxygen (DO) concentration, and $\mathrm{pH}$. Relations between potential explanatory factors and water quality were evaluated using statistical tests for correlation and by analysis of graphical relations.

A subset of the constituents and constituent classes was selected for evaluation in the understanding assessment that met the following criteria:

- Constituents for which aquifer-scale proportions were high for greater than or equal to 2 percent of the primary aquifer system in either study area.

- Classes of organic constituents and special-interest constituents for which study-area detection frequencies were 10 percent or more in the USGS grid sites, regardless of concentration. 
Table 2. Benchmark type and value and reporting limits for inorganic, organic, and special-interest constituents either detected at moderate or high relative concentrations in groundwater samples collected by the U.S. Geological Survey (USGS) in 2010 or reported in California Division of Drinking Water (SWRCB-DDW) database from 2007 to 2010, or, for organic constituents only, detected at any concentration in samples from more than 10 percent of USGS grid sites in either study area in 2010, Bear Valley and Lake Arrowhead Watershed (BEAR) study unit, California Groundwater Ambient Monitoring and Assessment (GAMA) Priority Basin Project.

[Benchmark type: Regulatory, health-based benchmarks: MCL-CA, SWRCB-DDW maximum contaminant level; MCL-US, U.S. Environmental Protection Agency (EPA) maximum contaminant level. Non-regulatory, health-based benchmarks: AL-US, EPA action level; NL-CA, SWRCB-DDW notification level. Non-regulatory, aesthetic-based benchmarks: SMCL-CA, SWRCB-DDW secondary maximum contaminant level. Benchmark units: mg/L, milligrams per liter; $\mathrm{pCi} / \mathrm{L}$, picocuries per liter; $\mu \mathrm{g} / \mathrm{L}$, micrograms per liter. Abbreviations: BV, Bear Valley study area; CSU, combined standard uncertainty; LAW, Lake Arrowhead Watershed study area; MTBE, methyl tert-butyl ether; THM, trihalomethane; VOC, volatile organic compound; \pm , plus or minus]

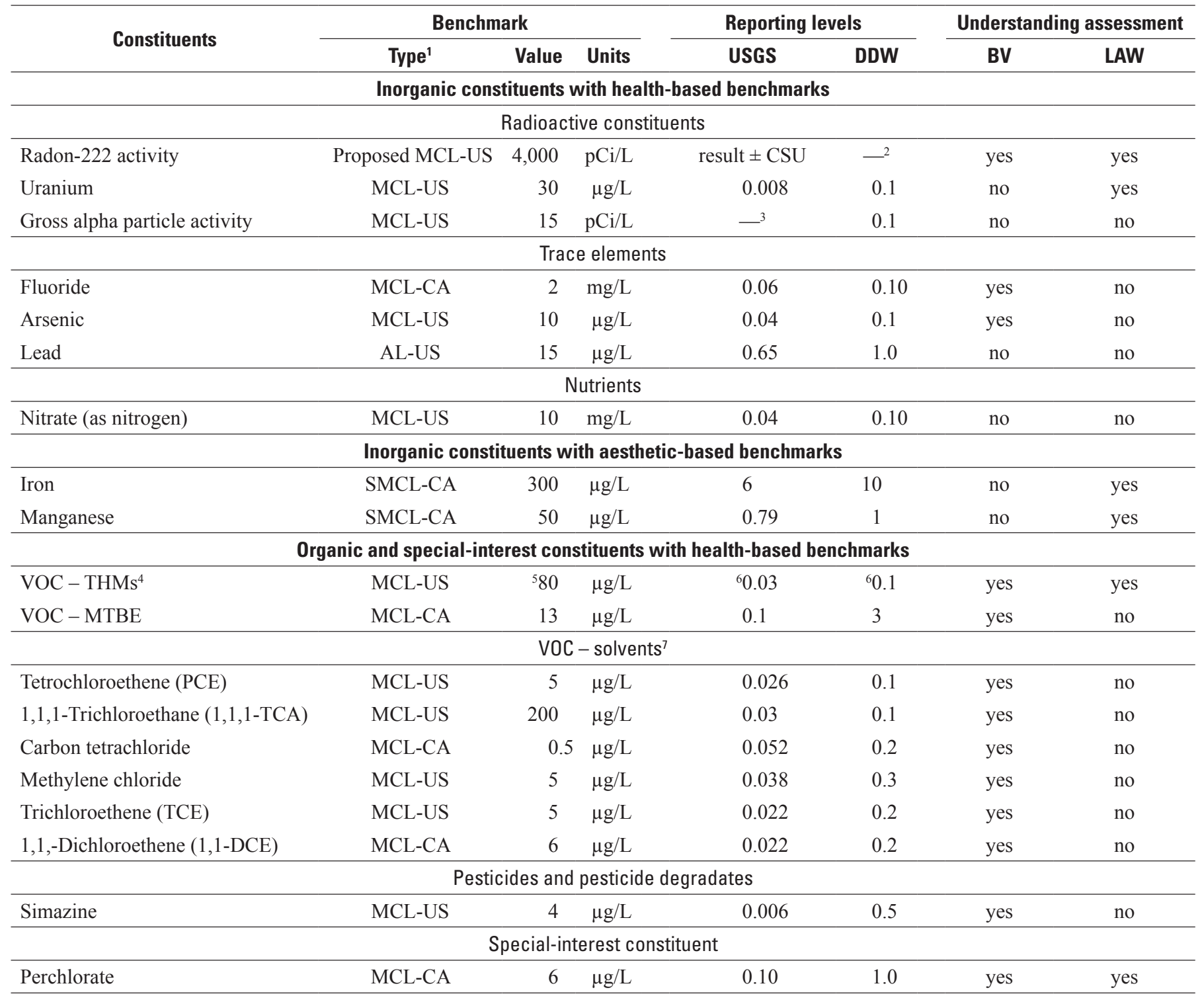

${ }^{1}$ Maximum contaminant level benchmarks are listed as MCL-US when the MCL-US and MCL-CA are identical, and as MCL-CA when the MCL-CA is lower than the MCL-US or no MCL-US exists.

${ }^{2}$ The constituent was not sampled for by the SWRCB-DDW from April 1, 2007, to April 1, 2010.

${ }^{3}$ The constituent was not sampled for by the USGS-GAMA.

${ }^{4}$ Chloroform, bromodichloromethane, dibromochloromethane, and bromoform all were detected and were summed together and grouped for the understanding assessment.

${ }^{5}$ The benchmark value is for the sum of four trihalomethanes (chloroform, bromodichloromethane, dibromochloromethane, and bromoform)

${ }^{6}$ The reporting unit was for chloroform, which was detected in greater than 10 percent of the USGS grid sites.

${ }^{7}$ The detections of solvents were summed together and grouped for the understanding assessment. 
Table 3. Benchmark type and value and reporting limits for constituents detected in groundwater samples collected in 2010 by the U.S. Geological Survey (USGS) either with no benchmarks or present only at low relative concentrations, Bear Valley and Lake Arrowhead Watershed study unit, California, Groundwater Ambient Monitoring and Assessment (GAMA) Priority Basin Project.

[Benchmark type: Regulatory, health-based benchmarks: MCL-CA, SWRCB-DDW maximum contaminant level; MCL-US, U.S. Environmental Protection Agency (EPA) maximum contaminant level. Non-regulatory, health-based benchmarks: AL-US, EPA action level; HAL-US, EPA lifetime health advisory level; NL-CA, SWRCB-DDW notification level. Non-regulatory, aesthetic-based benchmarks: SMCL-CA, California Division of Drinking Water (SWRCB-DDW) secondary maximum contaminant level. Benchmark units: $\mathrm{mg} / \mathrm{L}$, milligrams per liter; $\mu \mathrm{g} / \mathrm{L}$, micrograms per liter. Abbreviations: C, carbon; CSU, combined standard uncertainty; $\mathrm{H}$, hydrogen; He, helium; N, nitrogen; O, oxygen; Sr, strontium; VOC, volatile organic compound; \pm , plus or minus]

\begin{tabular}{|c|c|c|c|c|c|}
\hline \multirow{2}{*}{ Constituents } & \multicolumn{3}{|c|}{ Benchmark } & \multicolumn{2}{|c|}{ Reporting levels } \\
\hline & Type $^{1}$ & Value & Units & USGS & DDW \\
\hline \multicolumn{6}{|c|}{ Inorganic constituents with health-based benchmarks } \\
\hline Aluminum & MCL-CA & 1,000 & $\mu \mathrm{g} / \mathrm{L}$ & 3.4 & 50 \\
\hline Antimony & MCL-US & 6 & $\mu \mathrm{g} / \mathrm{L}$ & 0.054 & 6 \\
\hline Beryllium & MCL-US & 4 & $\mu \mathrm{g} / \mathrm{L}$ & 0.012 & 1 \\
\hline Boron & NL-CA & 1,000 & $\mu \mathrm{g} / \mathrm{L}$ & 2.8 & 10 \\
\hline Cadmium & MCL-US & 5 & $\mu \mathrm{g} / \mathrm{L}$ & 0.02 & 1 \\
\hline Chromium & MCL-CA & 50 & $\mu \mathrm{g} / \mathrm{L}$ & 0.42 & 1 \\
\hline Copper & AL-US & 1,300 & $\mu \mathrm{g} / \mathrm{L}$ & 1.7 & 50 \\
\hline Strontium & HAL-US & 4,000 & $\mu \mathrm{g} / \mathrm{L}$ & 0.40 & $-^{2}$ \\
\hline Thallium & MCL-US & 2 & $\mu \mathrm{g} / \mathrm{L}$ & 0.020 & 1 \\
\hline Vanadium & NL-CA & 50 & $\mu \mathrm{g} / \mathrm{L}$ & 0.16 & 0.1 \\
\hline \multicolumn{6}{|c|}{ Nutrients } \\
\hline Ammonia (as nitrogen) & HAL-US & ${ }^{3} 24.7$ & $\mathrm{mg} / \mathrm{L}$ & 0.02 & $-^{3}$ \\
\hline Nitrite (as nitrogen) & MCL-US & 1 & $\mathrm{mg} / \mathrm{L}$ & 0.001 & 100 \\
\hline \multicolumn{6}{|c|}{ Organic and special-interest constituents with health-based benchmarks } \\
\hline \multicolumn{6}{|c|}{ VOCs } \\
\hline \multicolumn{6}{|c|}{ Inorganic constituents with aesthetic-based benchmarks } \\
\hline \multicolumn{6}{|c|}{ Trace elements } \\
\hline Silver & SMCL-CA & 100 & $\mu \mathrm{g} / \mathrm{L}$ & 0.010 & 10 \\
\hline Zinc & SMCL-CA & 5,000 & $\mu \mathrm{g} / \mathrm{L}$ & 4.8 & 50 \\
\hline \multicolumn{6}{|c|}{ Major and minor ions } \\
\hline Chloride & SMCL-CA & 500 & $\mu \mathrm{g} / \mathrm{L}$ & 0.12 & 0.10 \\
\hline Sulfate & SMCL-CA & 500 & $\mu \mathrm{g} / \mathrm{L}$ & 0.18 & 0.10 \\
\hline Total dissolved solids (TDS) & SMCL-CA & 500 & $\mu \mathrm{g} / \mathrm{L}$ & 10 & 10 \\
\hline
\end{tabular}


Table 3. Benchmark type and value and reporting limits for constituents detected in groundwater samples collected in 2010 by the U.S. Geological Survey (USGS) either with no benchmarks or present only at low relative concentrations, Bear Valley and Lake Arrowhead Watershed study unit, California, Groundwater Ambient Monitoring and Assessment (GAMA) Priority Basin Project.Continued

[Benchmark type: Regulatory, health-based benchmarks: MCL-CA, SWRCB-DDW maximum contaminant level; MCL-US, U.S. Environmental Protection Agency (EPA) maximum contaminant level. Non-regulatory, health-based benchmarks: AL-US, EPA action level; HAL-US, EPA lifetime health advisory level; NL-CA, SWRCB-DDW notification level. Non-regulatory, aesthetic-based benchmarks: SMCL-CA, California Division of Drinking Water (SWRCB-DDW) secondary maximum contaminant level. Benchmark units: $\mathrm{mg} / \mathrm{L}$, milligrams per liter; $\mu \mathrm{g} / \mathrm{L}$, micrograms per liter. Abbreviations: C, carbon; CSU, combined standard uncertainty; $\mathrm{H}$, hydrogen; He, helium; N, nitrogen; O, oxygen; Sr, strontium; VOC, volatile organic compound; \pm , plus or minus]

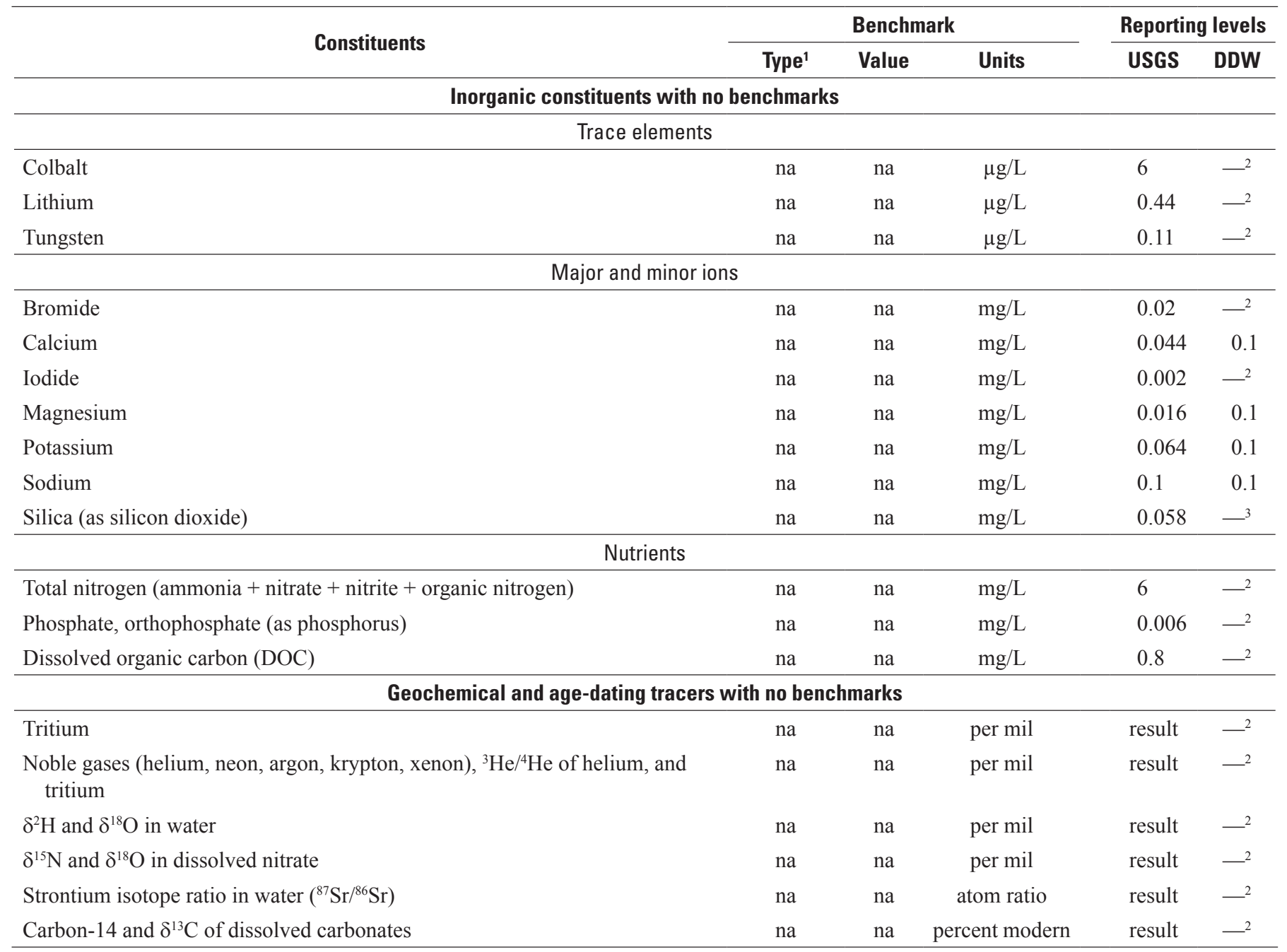

${ }^{1}$ Maximum contaminant level benchmarks are listed as MCL-US when the MCL-US and MCL-CA are identical, and as MCL-CA when the MCL-CA is lower than the MCL-US or no MCL-US exists.

${ }^{2}$ The constituent was not sampled for by the SWRCB-DDW from April 1, 2007, to April 1, 2010.

${ }^{3}$ The HAL-US is $30 \mathrm{mg} / \mathrm{L}$ (as ammonia). To facilitate comparison to the analytical results, we have converted and reported this HAL-US as $24.7 \mathrm{mg} / \mathrm{L}$ (as nitrogen). 
Table 4. Constituents historically reported at concentrations greater than benchmarks in the California Division of Drinking Water (SWRCB-DDW) database (July 6, 1982-March 31, 2007), but not during the 3-year period used in the status assessment for groundwater quality, Bear Valley and Lake Arrowhead Watershed study unit, April 1, 2007-April 1, 2010, California Groundwater Ambient Monitoring and Assessment (GAMA) Priority Basin Project.

[Benchmark type: Regulatory, health-based benchmarks: MCL-CA, SWRCB-DDW maximum contaminant level; MCL-US, U.S. Environmental Protection Agency (EPA) maximum contaminant level. Non-regulatory, health-based benchmarks: NL-CA, SWRCB-DDW notification level. Nonregulatory, aesthetic-based benchmarks: SMCL-CA, SWRBC-DDW secondary maximum contaminant level. Benchmark units: mg/L, milligrams per liter; $\mathrm{pCi} / \mathrm{L}$, picocuries per liter; $\mu \mathrm{g} / \mathrm{L}$, micrograms per liter. Abbreviations: mm/dd/yyy; month/day/year; TDS, total dissolved solids; THM, trihalomethane; USGS, U.S. Geological Survey]

\begin{tabular}{|c|c|c|c|c|c|c|}
\hline \multirow[b]{2}{*}{ Constituents } & \multicolumn{3}{|c|}{ Benchmark } & \multirow{2}{*}{$\begin{array}{l}\text { Number of sites with } \\
\text { historical data }\end{array}$} & \multirow{2}{*}{$\begin{array}{l}\text { Number of sites } \\
\text { with a high value }\end{array}$} & \multirow{2}{*}{$\begin{array}{l}\text { Date of most } \\
\text { recent high value } \\
\text { (mm/dd/yyyy) }\end{array}$} \\
\hline & Type $^{1}$ & Value & Units & & & \\
\hline \multicolumn{7}{|c|}{ Inorganic constituents } \\
\hline Gross beta particle activity ${ }^{2}$ & MCL-CA & 50 & $\mathrm{pCi} / \mathrm{L}$ & 29 & 1 & $03 / 26 / 1987$ \\
\hline Aluminum & MCL-CA & 1,000 & $\mu \mathrm{g} / \mathrm{L}$ & 143 & 2 & $06 / 08 / 2005$ \\
\hline Zinc & SMCL-CA & 5,000 & $\mu \mathrm{g} / \mathrm{L}$ & 163 & 2 & $07 / 26 / 2005$ \\
\hline TDS & SMCL-CA & 1,000 & $\mathrm{mg} / \mathrm{L}$ & 164 & 1 & $08 / 13 / 2003$ \\
\hline \multicolumn{7}{|c|}{ Organic constituents } \\
\hline Benzene & MCL-CA & 1 & $\mu \mathrm{g} / \mathrm{L}$ & 167 & 3 & 03/04/1992 \\
\hline
\end{tabular}

${ }^{1}$ Maximum contaminant level benchmarks are listed as MCL-US when the MCL-US and MCL-CA are identical, and as MCL-CA when the MCL-CA is lower than the MCL-US or no MCL-US exists.

${ }^{2}$ The constituent was not sampled for by USGS-GAMA.

${ }^{3}$ The MCL-US benchmark for THMs is for the sum of chloroform, bromodichloromethane, dibromochloromethane, and bromoform.

Nonparametric statistical methods were used to test for significant differences between the study areas and for correlations between the potential explanatory factors and the water-quality constituents. Nonparametric statistics are robust techniques that generally are resistant to outliers and do not require that the data follow any particular distribution (Helsel and Hirsch, 2002). The significance level ( $p$ ) used for hypothesis testing for this report was compared to a threshold value $(\alpha)$ in order to evaluate whether the relation was statistically significant $(p<\alpha)$. A threshold value of 5 percent $(\alpha=0.05)$ was used for testing differences between the study areas for individual potential explanatory factors and for individual water-quality constituents. For nonparametric statistical tests, non-detections of individual water-quality constituents were either classified as low RC or given a low value of 0.00001 depending on the appropriate statistical test. All statistical tests were done using TIBCO Spotfire $\mathrm{S}+{ }^{\circledR} 8.1$ for Windows (TIBCO Software Inc., 2008). Three different nonparametric statistical tests were used in this study.

Differences between the study areas for continuous variables (land use; density of septic tanks and LUFTs; elevation; aridity index; well construction, including well depth, depth to top of perforation, and perforation length; $\mathrm{pH}$; and dissolved oxygen concentration) were evaluated using the Wilcoxon rank-sum test. Differences in RC of water-quality constituents among categories of some potential explanatory factors were also investigated using the Wilcoxon rank-sum test. The Wilcoxon rank-sum test is conceptually a test of group medians that compares two independent data groups (categories) to determine whether one group contains greater values of some dependent variable than the other (Helsel and Hirsch, 2002). The null hypothesis for the two-sided Wilcoxon rank-sum test is that there is no significant difference between the observations of the two independent data groups.

Differences between the study areas for categorical variables (aquifer lithology, site type, groundwater age, and oxidation-reduction condition) were evaluated using contingency tables. Relations between RC categorical frequencies for water-quality constituents and some potential explanatory factors were also investigated using contingency tables. For a contingency table analysis, the data are recorded as a matrix of counts. One variable is assigned to the columns and the other to the rows, and the entries in the cells of the matrix are the number of observations, $\mathrm{O}_{\mathrm{ij}}$, that fall into the $t^{\text {th }}$ row and $j^{\text {th }}$ column of the matrix. A test statistic is computed by comparing the observed counts $\left(\mathrm{O}_{\mathrm{ij}}\right)$ to the counts expected if the two variables were independent, and significance is determined by comparing the test statistic to the $(1-\alpha)$ quantile of a chi-squared distribution. If the contingency-table test of independence yielded a significant result, then the location of the most important pairs (cells) was determined by comparing magnitudes of the components of the test statistic. 
Correlations between two variables measured on continuous scales (for example, water-quality constituents) were investigated using Spearman's method to calculate the rank-order correlation coefficient (rho) between the constituents. The values of rho can range from +1.0 (perfect positive correlation), through 0.0 (no correlation), to -1.0 (perfect negative correlation).

\section{Evaluation of Potential Explanatory Factors}

The values assigned to USGS grid and understanding sites are summarized in appendix tables $1-1$ to $1-4$ for the potential explanatory factors aquifer lithology, land use, density of septic tanks and LUFTs, elevation, aridity index, well construction (well depth and depth to top of perforation), site type, groundwater age, oxidation-reduction condition, DO concentration, and $\mathrm{pH}$. Methods used for assigning the values for each factor are described in appendix 1.

Statistical tests of differences between the study areas and relations between the potential explanatory factors used data only for the USGS grid sites, because they were used to characterize the primary aquifer system. The values assigned to the USGS understanding sites are only used in the understanding assessment as an additional tool to help identify the processes that control the distribution and concentrations of water-quality constituents in the BEAR study unit.

\section{Aquifer Lithology}

Aquifer lithology at the BEAR study-unit sites was classified into three categories on the basis of the lithologic information from the CDWR well-completion reports and the surficial geology on the California state geologic map (Jennings, 1977; Saucedo and others, 2000): sedimentary deposits, metamorphic rock, and granitic rock aquifer lithologies (appendix 1).

As discussed in the "Hydrogeologic Setting" section, the two study areas in the BEAR study unit are geologically distinct, and contingency-table tests confirmed significant differences in aquifer lithology between the BV and LAW study areas (table 5; fig. 4). The primary surficial lithology classification in the BV study area is sedimentary deposits, which composes about 82 percent of the study area (fig. 3).
Ten of the USGS grid sites have a sedimentary deposit aquifer lithology, three sites have sedimentary deposits and metamorphic rock aquifer lithology, and one site has a metamorphic rock aquifer lithology (appendix table 1-1). The primary surficial lithology classification in the LAW study area is granitic rock, which composes about 96 percent of the study area (fig. 3). All 13 of the USGS grid sites in the LAW study area have a granitic rock aquifer lithology (appendix table 1-1).

\section{Land Use}

Land use in 2001 was categorized into three types: urban, agricultural, and natural (appendix 1). Percentages of the three types were calculated for the study unit and study area as a whole and for the circular area within 500 meters (500-meter buffers) around each SWRCB-DDW site and USGS grid site (Johnson and Belitz, 2009).

Land use in the BEAR study unit as a whole was 70 percent natural, 30 percent urban, and less than 0.1 percent agricultural (LaMotte, 2008). Land use in 500-meter (m) buffers around the SWRCB-DDW sites as a whole was 38 percent natural, 62 percent urban, and 0.1 percent agricultural. Land use in the 500-m buffers around the USGS grid sites as a whole was 45 natural, 55 urban, and less than 0.1 percent agricultural. The difference between overall land use and land use in the 500-m buffers around the SWRCBDDW sites and the USGS grid sites reflects that the sites are preferentially located near where there are people living and working.

Wilcoxon rank-sum tests showed that land use in the BV study area was significantly more urban than in the LAW study area, and that the LAW study area was significantly more natural than the BV study area (table 5; figs. 5A, $B$ ). Forests account for almost all of the natural land-use class in the study unit. The largest urban areas are the cities of Big Bear and Lake Arrowhead, although there has been increased urbanization of smaller communities in each of the study areas over the last two decades. Agricultural lands account for minimal land use in the study unit (figs. 6A, $B$ ).

Land use in the BV study area as a whole was 42 percent natural, 58 percent urban, and less than 0.1 percent agricultural (fig. 5A). Land use in 500-m buffers around the SWRCBDDW sites was 38 percent natural and 62 percent urban on average. Land use in the 500-m buffers around the USGS grid sites was similar to that for SWRCB-DDW sites (fig. $5 A$ ). 
Table 5. Results of statistical tests using data for U.S. Geological Survey (USGS) grid sites to identify significant differences between the Bear Valley and Lake Arrowhead Watershed study areas, 2010, California Groundwater Ambient Monitoring and Assessment (GAMA) Priority Basin Project.

[Only results with p-values less than or equal to $(\leq) 0.05$ are considered significant in the statistical tests to determine differences between the study areas. Abbreviations: BV, Bear Valley study area; c, contingency table test; G, granitic rocks; LAW, Lake Arrowhead Watershed study area; LUFT, leaking or formerly leaking underground fuel tank; MTBE, methyl tert-butyl ether; ns, no significant difference; p-value, probability of obtaining a test statistic of equal or less likelihood when null hypothesis of no difference is true; S, sedimentary rocks; THM, trihalomethane; w, Wilcoxon rank-sum test; >, greater than; =, equal to]

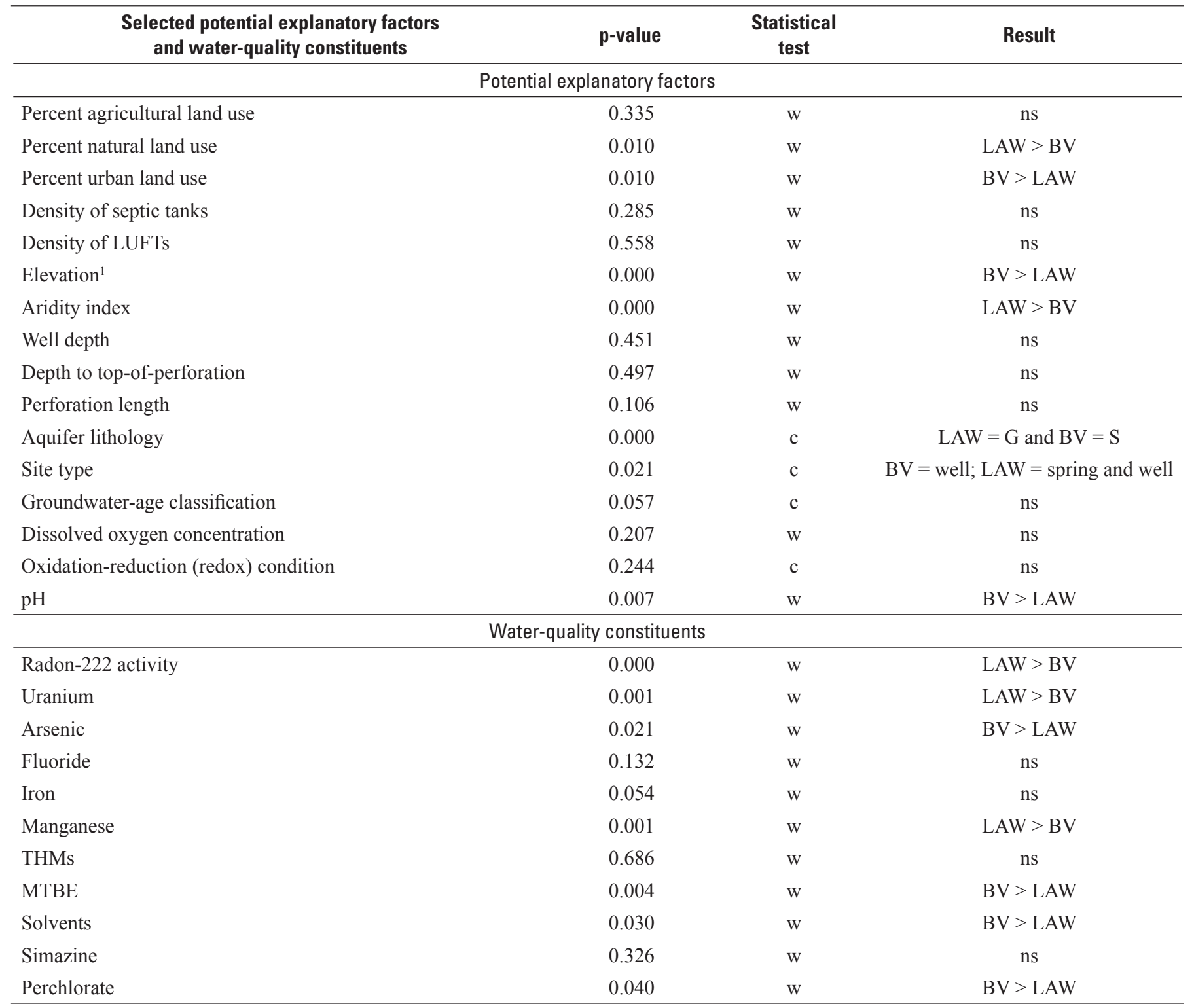

${ }^{1}$ Site elevation is given as the altitude of its land-surface datum (LSD). Each LSD is a datum plane that is approximately at land surface at the site. The altitude of the LSD is described in feet above the North American Vertical Datum 1988. 


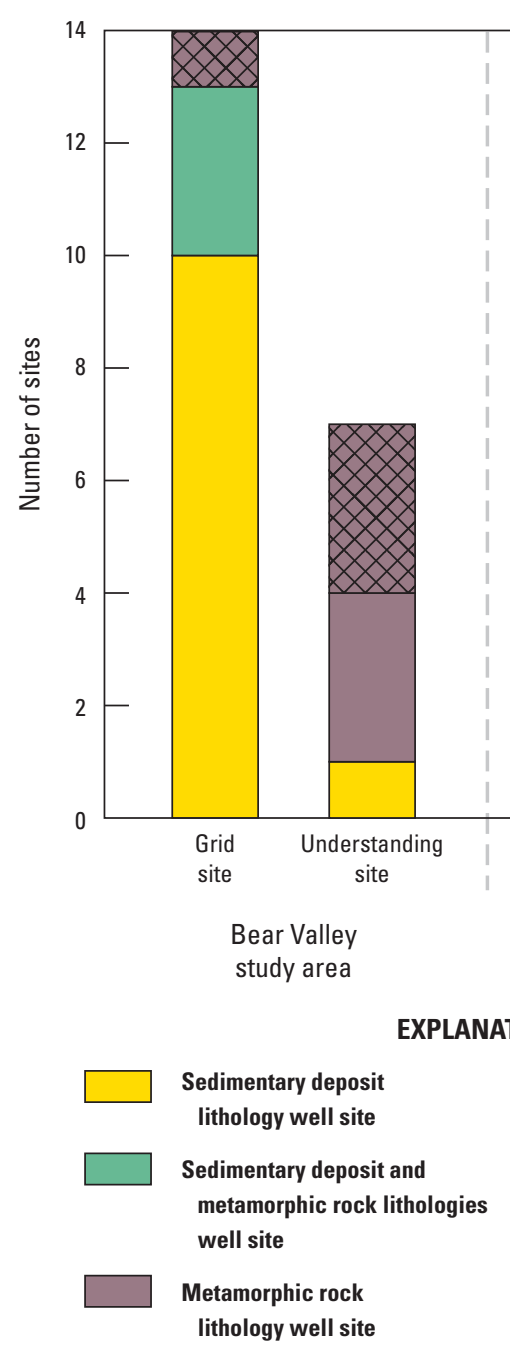

Figure 4. Frequency of aquifer lithology and by site type and study area for the U.S. Geological Survey (USGS) grid and understanding sites in the Bear Valley and Lake Arrowhead Watershed study areas, 2010, California Groundwater Ambient Monitoring and Assessment (GAMA) Priority Basin Project.

Land use in the LAW study area as a whole was 79 percent natural, 21 percent urban, and less than 0.1 percent agricultural (fig. $5 \mathrm{~A}$ ). The average land use in 500 -m buffers around the SWRCB-DDW sites was 68 percent natural and 32 percent urban. The average land use in the $500-\mathrm{m}$ buffers around the USGS grid sites was slightly more urban (43 percent urban) than land use around the SWRCB-DDW sites (fig. 5A).

\section{Density of Septic Tanks and Leaking Underground Fuel Tanks}

Septic tanks and LUFTs also act as markers of land-use patterns (appendix 1). Septic systems generally are associated with scattered residences and areas where land use is classified as natural (Waller, 1988). Septic systems are sometimes found in areas where there has been recent urbanization of natural lands (Shelton, 2005). The LUFTs generally are associated with areas of urban land use (California State Water Resources Control Board, 1995). Wilcoxon ranksum test comparisons showed that there was no significant difference between the study areas in the density of septic tanks or LUFTs surrounding the USGS grid sites (table 5). In the BV study area, the median densities of septic tanks and LUFTs were 1.2 tanks per square kilometer $\left(\operatorname{tanks} / \mathrm{km}^{2}\right)$ and 0.05 tanks $/ \mathrm{km}^{2}$, respectively. In the LAW study area, the median densities of septic tanks and LUFTs surrounding USGS grid sites were 2.1 tanks $/ \mathrm{km}^{2}$ and 0.03 tanks $/ \mathrm{km}^{2}$, respectively (figs. $6 A, B$; appendix table $1-1$ ).

\section{Elevation}

The elevation of a well or spring at the land surface was used as a proxy for relative position in the regional groundwater-flow system (appendix 1). Elevation is presented in this report in feet above the North American Vertical Datum of 1988 (NAVD 88). The median elevation of the USGS grid sites in the BV study area was $6,850 \mathrm{ft}$, whereas the median elevation of the sites in the LAW study area was $5,288 \mathrm{ft}$ (appendix table 1-2). Wilcoxon rank-sum tests confirmed that the land surface at grid sites of the BV study area is significantly higher in elevation than it is at sites of the LAW study area (table 5).

\section{Aridity Index}

The aridity index is equal to the average annual precipitation (PRISM Group, 2012) divided by average annual evapotranspiration (Flint and Flint, 2007). The aridity index can be grouped into six classes: values less than 0.05 are defined as hyper-arid, 0.05 to less than or equal to 0.20 as arid, 0.20 to less than or equal to 0.50 as semi-arid, 0.50 to less than or equal to 0.65 as dry sub-humid, 0.65 to less than or equal to 1.00 as humid, and greater than 1.00 as wet. In the BV study area, the median aridity index was 0.47 (semi-arid), whereas the median for the LAW study area was 0.64 (dry sub-humid; appendix table 1-2). Wilcoxon rank-sum tests confirmed that the climate at USGS grid sites in the BV study area was significantly more arid than at USGS grid sites in the LAW study area (table 5). 
$\boldsymbol{A}$

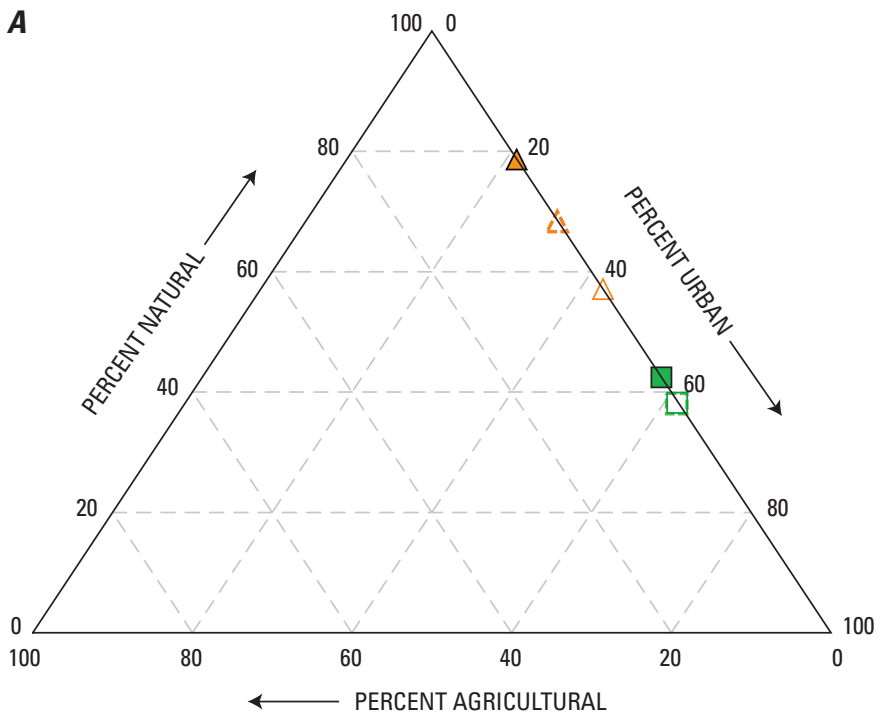

B

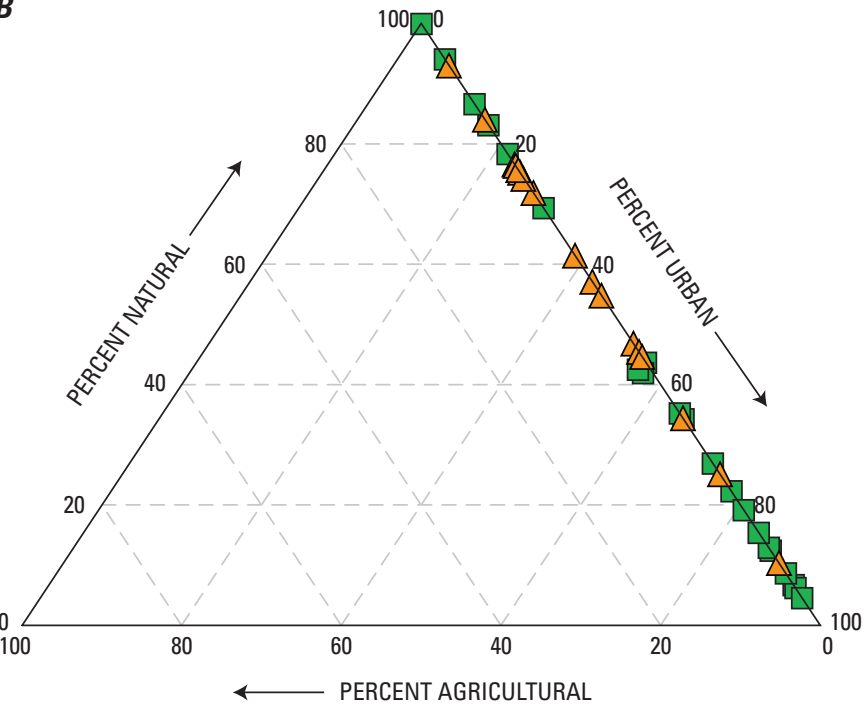

EXPLANATION

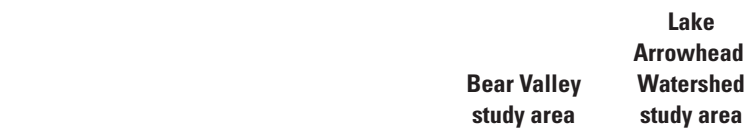

Land-use percentages for entire study area

$\triangle$

Average percentages in 500-meter buffer surrounding U.S. Geological Survey grid sites

Average percentages in 500-meter buffer surrounding California State Water Resources Control Board Division of Drinking Water sites

\section{EXPLANATION}

Bear Valley study area

$\triangle$ Lake Arrowhead Watershed study area

Figure 5. The 2001 land use as the percentage of urban, agricultural, and natural land uses in the Bear Valley and Lake Arrowhead Watershed study unit, California Groundwater Ambient Monitoring and Assessment (GAMA) Priority Basin Project: $A$, overall by study area, and averages by study area for circular buffer areas around U.S. Geological Survey (USGS) grid sites and California Division of Drinking Water (SWRCB-DDW) sites, and $B$, by site for the circular buffer area surrounding each USGS grid and understanding site. 
$\boldsymbol{A}$

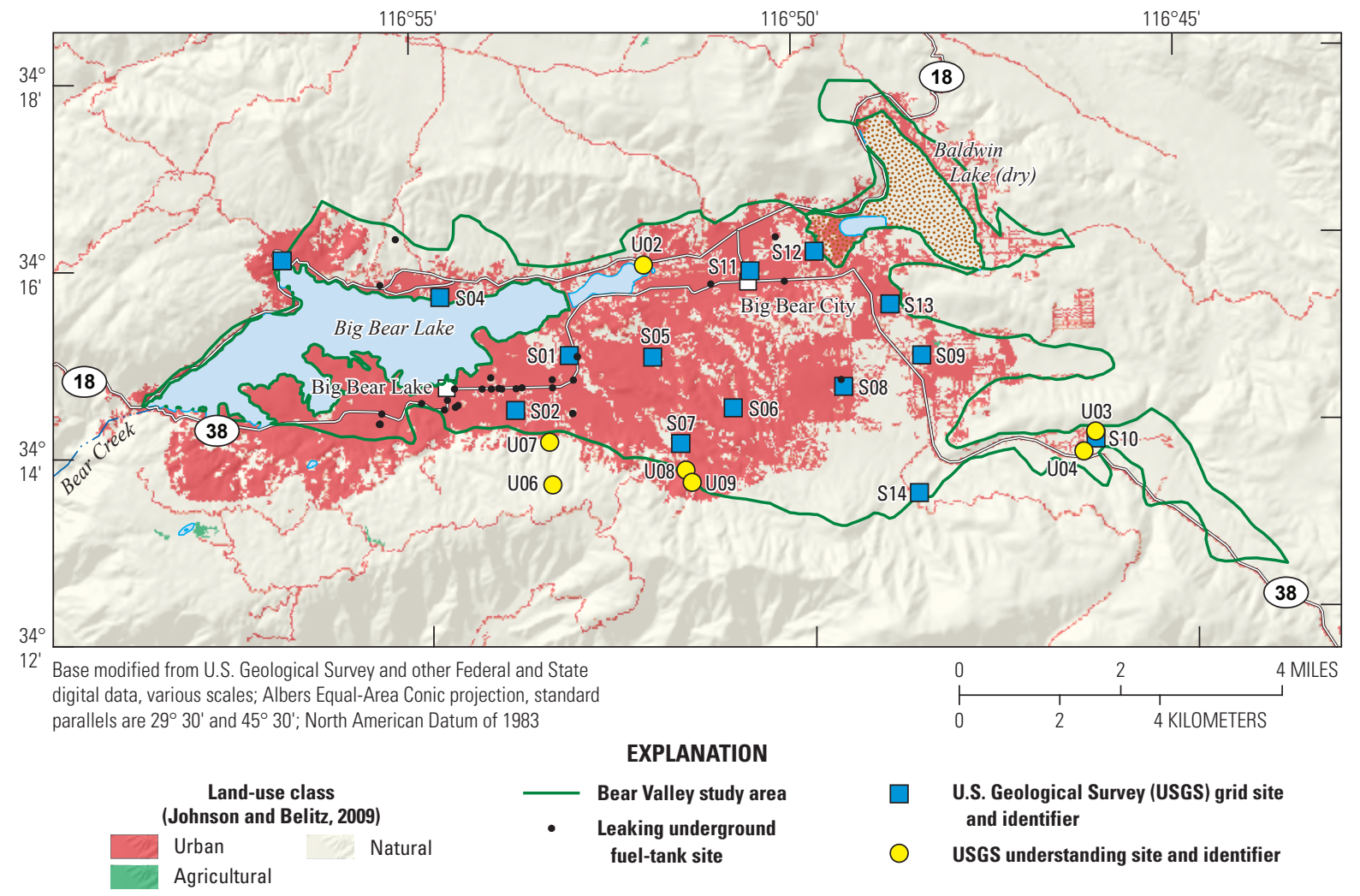

B

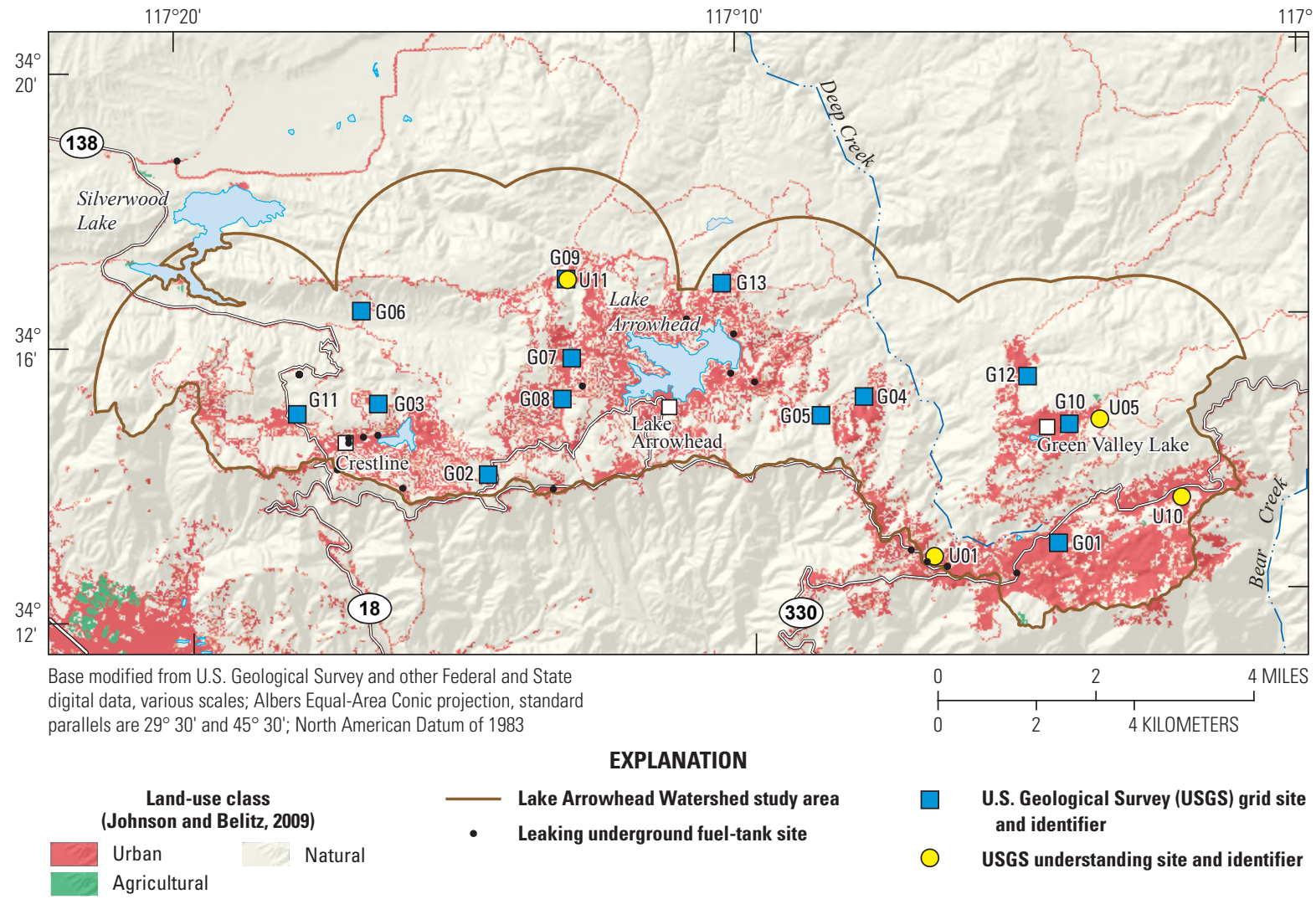

Figure 6. 2001 land use and location of leaking (or formerly leaking) underground fuel tanks (LUFTs) in two California Groundwater Ambient Monitoring and Assessment (GAMA) Priority Basin Project study areas: $A$, Bear Valley and $B$, Lake Arrowhead Watershed. (Land-use classes are aggregated from those used in the source database, LaMotte, 2008). 


\section{Well-Construction Information}

In the BEAR study unit, 20 of the 27 USGS grid sites were wells (13 in the BV study area and 7 in the LAW study area; fig. 7; appendix table 1-2). Wilcoxon rank-sum test comparisons showed no significant differences between the study areas in the depth of wells, depth to top of perforations, or perforation length (table 5). Seven of the USGS grid sites sampled in the BEAR study unit were springs (one in the BV study area and six in the LAW study area; appendix table 1-2). Springs were not included in the data used to test for significant differences between study areas in USGS grid well depth and depth to the top-of-perforation data because of uncertainty about the depth in the primary aquifer system at which the groundwater had resided before reaching the land surface.

\section{Groundwater Age}

Groundwater age refers to the amount of time elapsed since the water was last in contact with the atmosphere. Multiple groundwater-age tracers were analyzed for the BEAR study unit; however, not all age tracers were measured at all USGS-GAMA sites. The only groundwater-age tracer

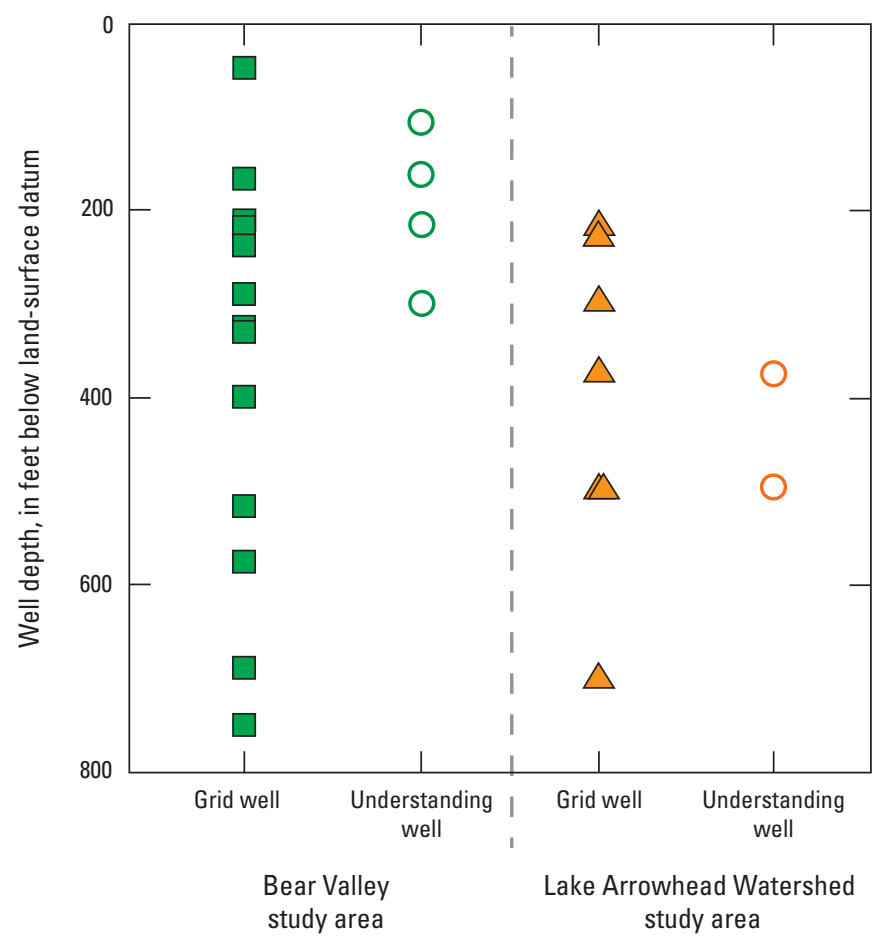

Figure 7. Well depth for the U.S. Geological Survey (USGS) grid and understanding wells in the Bear Valley and Lake Arrowhead Watershed study areas, 2010, California Groundwater Ambient Monitoring and Assessment (GAMA) Priority Basin Project. measured in samples from every site in the BEAR study unit was tritium. Tritium was used to classify groundwater age into three categories: mixed, modern, and pre-modern (fig. 8; appendix table 1-3). Groundwater samples with tritium activity greater than 2.0 tritium units (TU) were classified as "modern," groundwater with tritium activity less than or equal to 2.0 TU or greater than 0.3 TU was classified as "mixed," and groundwater with tritium activity less than or equal to 0.3 TU was classified as "pre-modern." Modern groundwater contains a substantial component of water recharged since 1952 (Michel, 1989). Carbon-14 was measured in samples from approximately 20 percent of the sites in the BEAR study unit. Where applicable, carbon-14 results are used in this report to support tritium-based age classifications. Although figure 8 shows that grid sites in the BV study area had a much higher frequency (36 percent) of pre-modern apparent age than did samples in the LAW study area ( 0 percent), the contingency-table test for independence showed no significant difference in groundwater-age class between study areas (table 5).

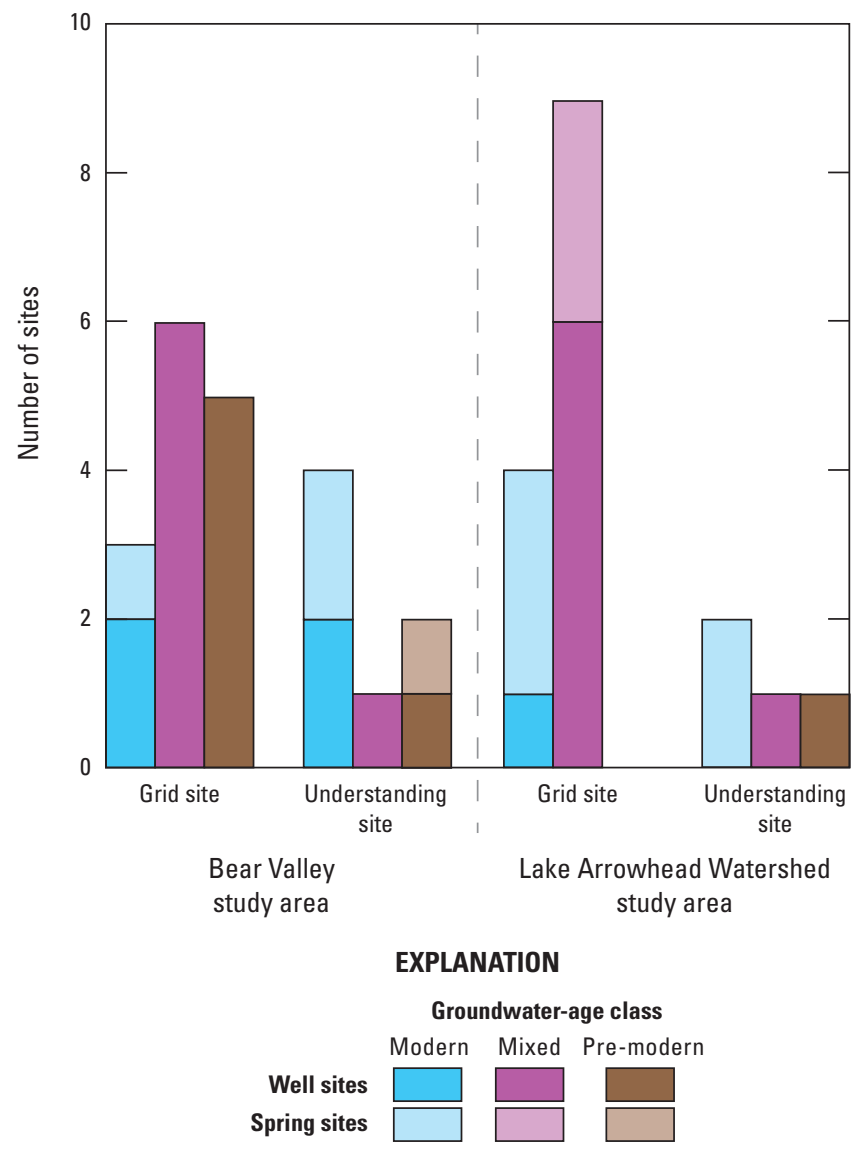

Figure 8. Frequency by age class of groundwater age, grouped by site type and by study area, for samples from the U.S. Geological Survey (USGS) grid and understanding sites in the Bear Valley and Lake Arrowhead Watershed study areas, 2010, California Groundwater Ambient Monitoring and Assessment (GAMA) Priority Basin Project. 


\section{Geochemical Conditions}

Sufficient chemical data, including DO concentration, were available to classify groundwater redox conditions into three categories: oxic, mixed, and anoxic (appendix 1). Oxic groundwater conditions are common in the BEAR study unit, where oxic conditions and elevated DO concentrations dominate samples from both study areas (appendix table 1-4). Contingency-table tests confirmed that there was no significant difference between the study areas in the redox conditions, and similarly, rank-sum tests revealed no significant difference in DO concentrations in groundwater samples from the USGS grid sites (table 5). In the BV study area, groundwater was classified as oxic at 13 of the USGS grid sites and anoxic at 1 site. In the LAW study area, groundwater was classified as oxic at 10 of the USGS grid sites and mixed at 3 sites (appendix table 1-4).

$\mathrm{A} \mathrm{pH}$ value indicates the acidity of the water. The $\mathrm{pH}$ values in the BEAR study unit ranged from 6.1 to 9.1 (appendix table 1-4). Wilcoxon rank-sum test comparisons showed that $\mathrm{pH}$ values were significantly greater in samples from USGS grid sites in the BV study area than those from the LAW study area (table 5). Both in sedimentary and granitic rock aquifer systems, $\mathrm{pH}$ values generally rise as acid is consumed by weathering reactions of silicate minerals and dissolution of carbonate minerals (if present; Stumm and Morgan, 1996; Appelo and Postma, 2005; Wright and Belitz, 2011). Although granitic rocks are known to have a high silicate content (commonly 50 to 80 percent of their composition; Frost and others, 2001), the structure of sedimentary rocks most likely allows for a greater amount of surface area for weathering reactions than in granitic rocks, which could account for the greater $\mathrm{pH}$ values in the $\mathrm{BV}$ study area compared to the LAW study area.

\section{Status and Understanding of Water Quality}

The following discussion of the status and understanding assessment results is divided into two parts - inorganic constituents and organic constituents - and each part has a tiered structure. Each part begins with a survey of the number of constituents that were detected at any concentration compared to the number of constituents analyzed and has a graphical summary of the RCs of constituents detected in samples from the USGS grid sites. Aquifer-scale proportions are then presented for constituent classes and for the individual constituents that were present at moderate or high RCs (constituents present only at low RCs have aquiferscale proportions of 100 percent low RC). Finally, results of statistical tests for relations between water quality and potential explanatory factors are presented for the individual constituents and constituent classes that met further criteria based on RCs or, for organic constituents, detection frequency.

\section{Inorganic Constituents}

Inorganic constituents are naturally present in groundwater, although their concentrations can be affected by human activities as well as by natural factors (Hem, 1985). Most of the constituents that do not have benchmarks are major or minor ions contained in nearly all groundwater (table 3). Of the 29 inorganic constituents that had benchmarks, 7 were detected at moderate or high RCs in samples from the USGS grid sites or the SWRCB-DDW sites: the radioactive constituent uranium; the trace elements with health-based benchmarks fluoride, lead, and arsenic; the nutrient nitrate; and the inorganic constituents with aestheticbased SMCL benchmarks, iron and manganese (table 2). Five inorganic constituents were selected because they were present at high RCs in greater than 2 percent of the primary aquifer system: uranium, fluoride, arsenic, iron, and manganese (table 2, figs. 9, 10).

In the BV study area, inorganic constituents with healthbased benchmarks (radioactive constituents, trace elements, and nutrients) had high RCs in 9.0 percent of the primary aquifer system and moderate RCs in 13 percent (table 6). In the LAW study area, inorganic constituents had high RCs in 25 percent of the primary aquifer system and moderate RCs in 41 percent.

Radon-222 was present at high and moderate RCs in the BEAR study unit (Mathany and Belitz, 2013); however, it is not discussed as part of the inorganic constituents as a class because the MCL-US is proposed (since 1999), and the purpose of the proposed benchmark is to address radon-222 concentration in indoor air, not health concerns associated with ingestion of drinking water containing radon-222. This study is focused on issues of concern related to groundwater sources of drinking water.

\section{Radioactive Constituents}

Most of the radioactivity in groundwater comes from decay of naturally existing uranium and thorium in the rocks or sediments of the aquifers. Radioactive decay of uranium and thorium isotopes produces a long series of radioactive daughter products, including isotopes of radium, uranium, and radon. These elements have different chemical properties, and their solubility in groundwater varies with geochemical conditions, water chemistry, and aquifer mineralogy (Hem, 1985). This study included USGS-GAMA data and SWRCBDDW data for uranium, USGS-GAMA data for radon-222, and SWRCB-DDW data for gross alpha-particle activity, which is an aggregrate measure of the activities of all radioactive elements in the water sample that decay by alphaparticle emission. Radioactive constituents were not present at high RCs in the BV study area, but were present at moderate RCs in 3.6 percent of the primary aquifer system (table 6). In contrast, in the LAW study area, radioactive constituents were present at high RCs in 25 percent of the primary aquifer system and at moderate RCs in 38 percent. Radon-222 was not included in these calculations. 


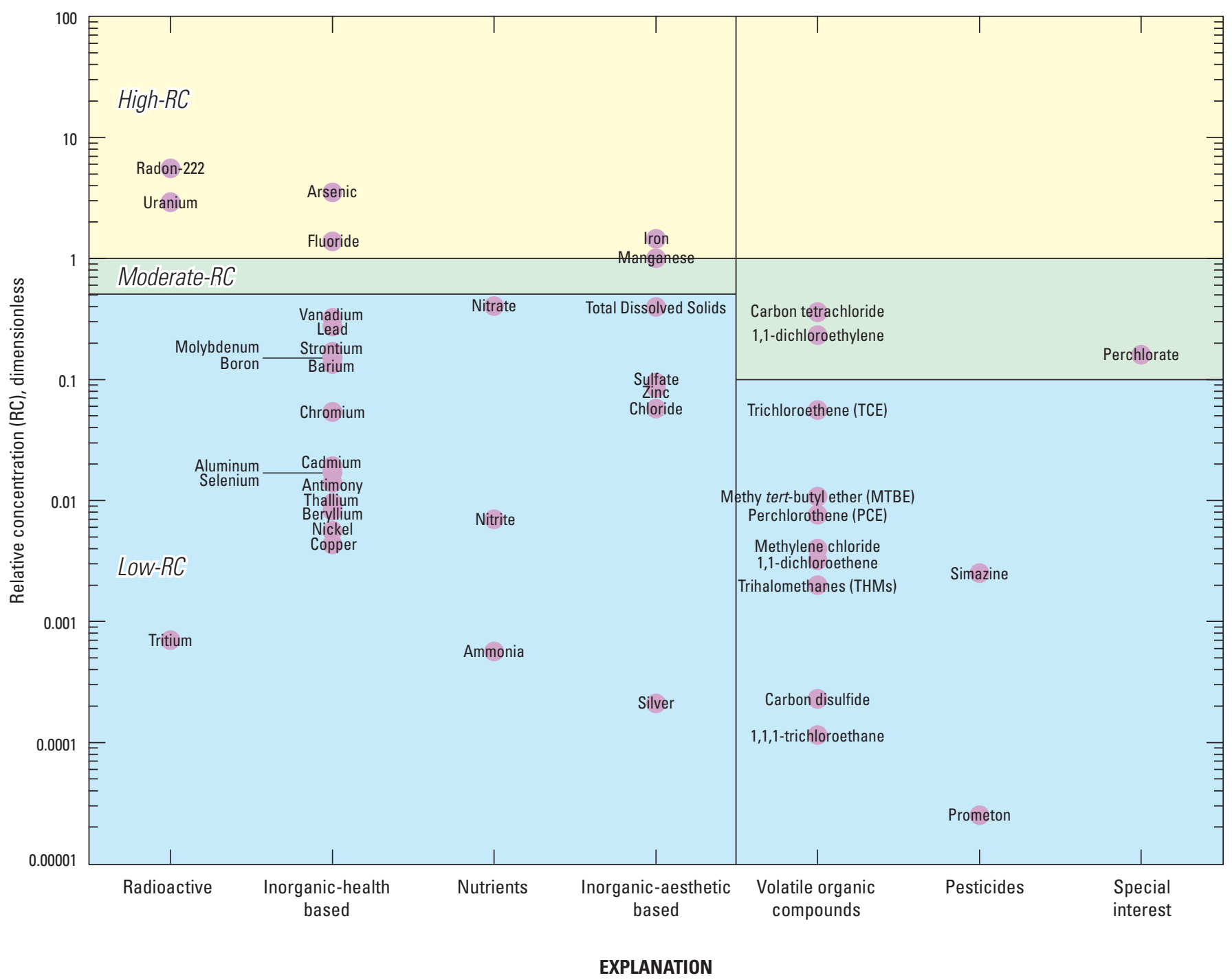

Perchlorate Name and center of symbol is location of data unless otherwise indicated by a leader line to plotting position

Figure 9. Maximum relative concentration of constituents detected in groundwater samples from U.S. Geological Survey (USGS) grid sites, by constituent class, Bear Valley and Lake Arrowhead Watershed study unit, 2010, California Groundwater Ambient Monitoring and Assessment (GAMA) Priority Basin Project. 


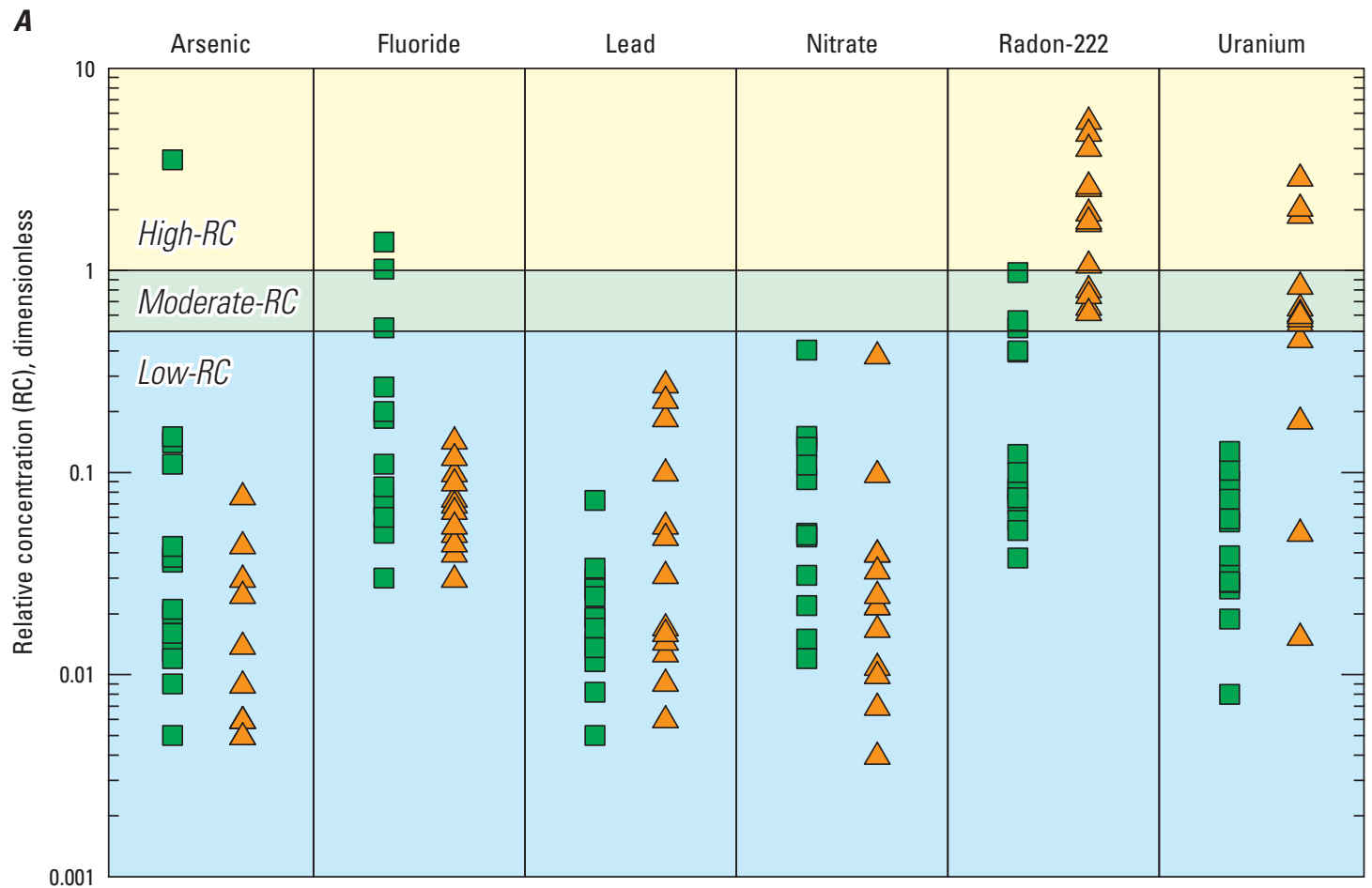

EXPLANATION

Study area

Bear Valley

$\triangle$ Lake Arrowhead Watershed

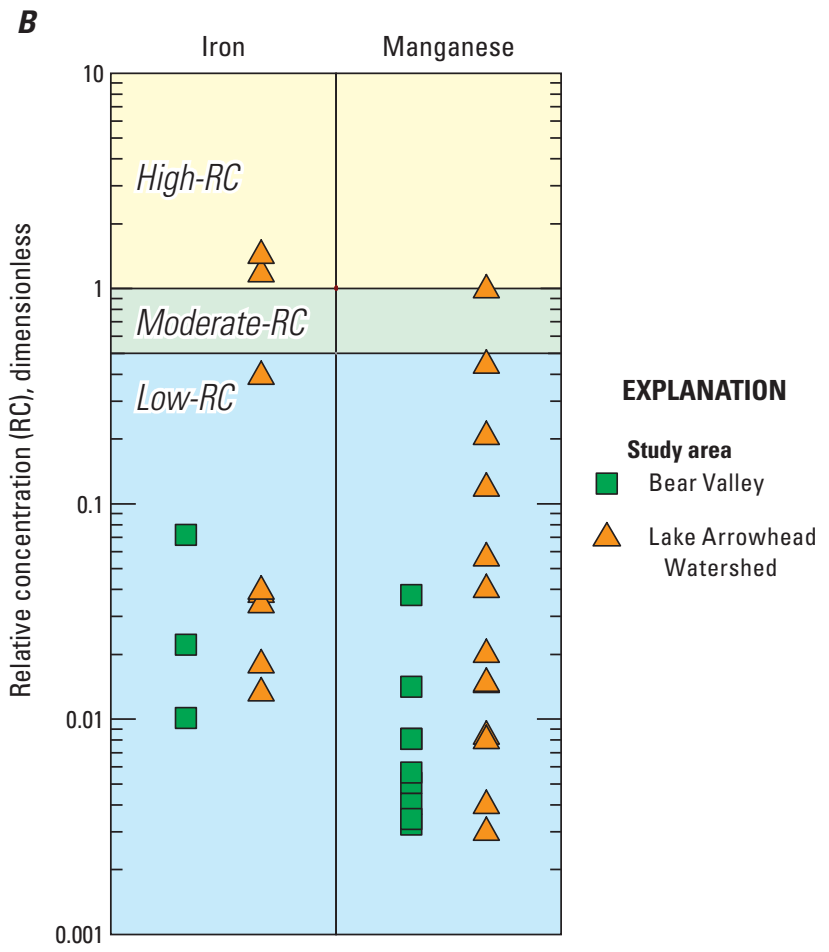

Figure 10. Relative concentrations of selected constituents in groundwater samples from U.S. Geological Survey (USGS) grid sites, Bear Valley and Lake Arrowhead Watershed study unit, 2010, California Groundwater Ambient Monitoring and Assessment (GAMA) Priority Basin Project: $A$, constituents with health-based benchmarks and $B$, constituents with aesthetic-based benchmarks. 
Table 6. Summary of aquifer-scale proportions by relative-concentration category for inorganic and organic constituent classes and selected constituents for groundwater in the Bear Valley and Lake Arrowhead Watershed study unit, 2010, California Groundwater Ambient Monitoring and Assessment (GAMA) Priority Basin Project.

[Values are aquifer-scale proportions, in percent. Relative-concentration categories: high; concentration greater than the water-quality benchmark; moderate, concentration is less than the benchmark and is greater than or equal to 0.1 of the benchmark (for organic constituents) or 0.5 of the benchmark (for inorganic constituents). Abbreviations: BV, Bear Valley study area; LAW, Lake Arrowhead Watershed study area; SPAT, spatially weighted aquifer-scale proportion of area with indicated category of relative concentration; VOC, volatile organic compound; - , not applicable (see footnote 1)]

\begin{tabular}{|c|c|c|c|c|c|c|c|c|}
\hline \multirow[b]{2}{*}{ Study area } & \multicolumn{4}{|c|}{ BV } & \multicolumn{4}{|c|}{ LAW } \\
\hline & $\begin{array}{c}\text { Constituent } \\
\text { not } \\
\text { detected }^{1}\end{array}$ & $\begin{array}{l}\text { SPAT } \\
\text { Iow }\end{array}$ & $\begin{array}{c}\text { SPAT } \\
\text { moderate }\end{array}$ & $\begin{array}{l}\text { SPAT } \\
\text { high }\end{array}$ & $\begin{array}{c}\text { Constituent } \\
\text { not } \\
\text { detected }^{1}\end{array}$ & $\begin{array}{l}\text { SPAT } \\
\text { low }\end{array}$ & $\begin{array}{c}\text { SPAT } \\
\text { moderate }\end{array}$ & $\begin{array}{l}\text { SPAT } \\
\text { high }\end{array}$ \\
\hline \multicolumn{9}{|c|}{ Inorganic constituents with health-based benchmarks } \\
\hline Any inorganic constituent & - & 77.9 & 13.1 & 9.0 & - & 33.6 & 41.4 & 25.0 \\
\hline Trace elements $^{2}$ & - & 83.8 & 7.1 & 9.0 & - & 96.8 & 3.2 & 0 \\
\hline Uranium and other radioactive constituents & - & 96.4 & 3.6 & 0.0 & - & 37.4 & 37.5 & 25.1 \\
\hline \multicolumn{9}{|c|}{ Inorganic constituents with aesthetic-based benchmarks } \\
\hline Any inorganic constituent & - & 88.8 & 8.2 & 3.1 & - & 76.0 & 0.6 & 23.4 \\
\hline Trace elements (iron and manganese) & - & 88.8 & 8.2 & 3.1 & - & 76.0 & 0.6 & 23.4 \\
\hline Any organic constituent & 20.5 & 70.4 & 8.1 & 1.0 & 46.1 & 46.2 & 7.7 & 0 \\
\hline Any VOC & 20.5 & 70.4 & 8.1 & 1.0 & 53.8 & 38.5 & 7.7 & 0 \\
\hline Any pesticides and pesticide degradates ${ }^{3}$ & 78.6 & 21.4 & 0 & 0 & 92.3 & 7.7 & 0 & 0 \\
\hline
\end{tabular}

${ }^{1}$ For inorganic constituents, non-detections are included in the spatially weighted, aquifer-scale proportion in the low relative-concentration category.

${ }^{2}$ Includes the minor element fluoride due to it having a health-based benchmark.

${ }^{3}$ Only herbicides were detected.

The MCL-US of 15 picocuries per liter (pCi/L) for gross alpha-particle activity applies to adjusted gross alpha activity, which is equal to measured gross alpha activity minus uranium activity (U.S. Environmental Protection Agency, 2009b). Data compiled in the SWRCB-DDW water-quality database are reported as gross alpha activity without correction for uranium concentration. Gross alpha is used as a screening tool to determine whether other radioactive constituents must be analyzed. For regulatory purposes, analysis of uranium is only required if gross alpha activity is greater than $15 \mathrm{pCi} / \mathrm{L}$; therefore, the SWRCB-DDW water-quality database contains more data for gross alpha activity than for uranium. For the BEAR study unit, nearly all of the samples with gross alpha activities greater than $7.5 \mathrm{pCi} / \mathrm{L}$ also had data for uranium activity; therefore, adjusted gross alpha activities could be calculated (for gross alpha activities less than $7.5 \mathrm{pCi} / \mathrm{L}$, uranium concentration data are not required because the adjusted gross alpha activity would also have a low RC). The primary contributors to gross alpha activity are uranium and radium (Arndt, 2010). Because of the lack of data for other radioactive constituents in the SWRCB-DDW water-quality database, gross alpha data without correction for uranium are the primary data used in this report to avoid underestimating the prevalence of groundwater with moderate and high RCs of radioactive constituents as a class.

\section{Understanding Assessment for Radon-222}

Radon is an inert gas that readily diffuses out of the aquifer materials and into the groundwater. Wilcoxon ranksum tests showed that radon-222 activities were greater at USGS grid sites in the LAW study area than at USGS grid sites in the BV study area (table 5). In the BV study area, radon-222 was present at high RCs in 3.6 percent of the primary aquifer system and at moderate RCs in 21 percent of the primary aquifer system (table 7). In the LAW study area, radon-222 was present at high RCs in 62 percent of the primary aquifer system and at moderate RCs in 31 percent. 
Table 7. Aquifer-scale proportions by relative-concentration category, for selected groundwater-quality constituents that met criteria for additional evaluation in the status assessment for the Bear Valley and Lake Arrowhead Watershed study unit, 2010, California Groundwater Ambient Monitoring and Assessment (GAMA) Priority Basin Project.

[Values are aquifer-scale proportions, in percent, except where other units are given. Relative-concentration categories: high; concentration greater than water-quality benchmark; moderate, concentration is less than the benchmark and is greater than or equal to 0.1 of the benchmark (for organic and specialinterest constituents) or 0.5 of the benchmark (for inorganic constituents). Abbreviations: BV, Bear Valley study area; LAW, Lake Arrowhead Watershed study area; MTBE, methyl tert-butyl ether; PEST, pesticide; RAW, raw detection frequency; SIC, special-interest constituent; SPAT, spatially weighted aquiferscale proportion of area with indicated category of relative concentration; SWRCB-DDW, California Division of Drinking Water; THM, trihalomethane; USGS, U.S. Geological Survey; VOC, volatile organic compound]

\begin{tabular}{|c|c|c|c|c|c|c|c|c|c|c|c|c|}
\hline \multirow[b]{2}{*}{ Study area } & \multicolumn{6}{|c|}{ BV } & \multicolumn{6}{|c|}{ LAW } \\
\hline & $\begin{array}{l}\text { Number } \\
\text { of sites }\end{array}$ & $\begin{array}{c}\text { Number } \\
\text { of cells }\end{array}$ & $\begin{array}{c}\text { RAW } \\
\text { moderate }\end{array}$ & $\begin{array}{l}\text { RAW } \\
\text { high }\end{array}$ & $\begin{array}{c}\text { SPAT } \\
\text { moderate }\end{array}$ & $\begin{array}{c}\text { SPAT } \\
\text { high }\end{array}$ & $\begin{array}{l}\text { Number } \\
\text { of sites }\end{array}$ & $\begin{array}{c}\text { Number } \\
\text { of cells }\end{array}$ & $\begin{array}{c}\text { RAW } \\
\text { moderate }\end{array}$ & $\begin{array}{l}\text { RAW } \\
\text { high }\end{array}$ & $\begin{array}{c}\text { SPAT } \\
\text { moderate }\end{array}$ & $\begin{array}{l}\text { SPAT } \\
\text { high }\end{array}$ \\
\hline \multicolumn{13}{|c|}{ Inorganic constituents with health-based benchmarks } \\
\hline \multicolumn{13}{|c|}{ Radioactive constituents } \\
\hline Uranium & 20 & 14 & 5.0 & 0 & 3.6 & 0 & 47 & 13 & 25.5 & 34.0 & 42.5 & 25.9 \\
\hline $\begin{array}{l}\text { Unadjusted gross alpha } \\
\text { particle activity }^{1}\end{array}$ & 36 & 13 & 2.8 & 0 & 3.8 & 0 & 44 & 12 & 25.0 & 40.9 & 31.0 & 29.5 \\
\hline $\begin{array}{l}\text { Adjusted gross alpha } \\
\text { particle activity }{ }^{1}\end{array}$ & 36 & 13 & 0 & 0 & 0 & 0 & 43 & 11 & 9.3 & 2.3 & 4.1 & 1.8 \\
\hline \multicolumn{13}{|c|}{ Trace elements } \\
\hline Fluoride & 39 & 14 & 2.6 & 10.3 & 3.6 & 5.4 & 48 & 13 & 0 & 0 & 0 & 0 \\
\hline Arsenic & 39 & 14 & 5.1 & 2.6 & 7.1 & 3.6 & 48 & 13 & 0 & 0 & 0 & 0 \\
\hline Lead & 39 & 14 & 0 & 0 & 0 & 0 & 48 & 13 & 2.1 & 0 & 2.6 & 0 \\
\hline \multicolumn{13}{|c|}{ Nutrients } \\
\hline Nitrate (as nitrogen) & 45 & 14 & 2.2 & 0 & 1.8 & 0 & 69 & 13 & 2.9 & 0 & 2.7 & 0 \\
\hline \multicolumn{13}{|c|}{ Inorganic constituents with proposed benchmarks } \\
\hline 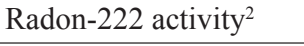 & 17 & 14 & 23.5 & 5.9 & 21.4 & 3.6 & 19 & 13 & 21.1 & 63.2 & 30.8 & 61.5 \\
\hline \multicolumn{13}{|c|}{ Inorganic constituents with aesthetic-based benchmarks } \\
\hline Iron & 39 & 14 & 2.6 & 5.1 & 1.0 & 2.0 & 47 & 13 & 2.1 & 10.6 & 0.6 & 18.9 \\
\hline Manganese & 39 & 14 & 5.1 & 7.7 & 7.1 & 3.1 & 47 & 13 & 0 & 6.4 & 0 & 8.3 \\
\hline \multicolumn{13}{|c|}{ Organic and special-interest constituents with health-based benchmarks } \\
\hline VOC - THMs & 24 & 14 & 0 & 0 & 0 & 0 & 43 & 13 & 0 & 0 & 0 & 0 \\
\hline VOC - MTBE & 39 & 14 & 0 & 0 & 0 & 0 & 53 & 13 & 0 & 0 & 0 & 0 \\
\hline VOC - solvents & 24 & 14 & 4.2 & 4.2 & 3.6 & 1.0 & 43 & 13 & 2.3 & 0 & 1.0 & 0 \\
\hline PEST - simazine & 21 & 14 & 0 & 0 & 0 & 0 & 29 & 13 & 0 & 0 & 0 & 0 \\
\hline SIC - perchlorate & 32 & 14 & 3.1 & 0 & 3.6 & 0 & 44 & 13 & 0 & 0 & 0 & 0 \\
\hline
\end{tabular}

${ }^{1}$ The constituent was not sampled for by the USGS-GAMA.

${ }^{2}$ The constituent was not sampled for by the SWRCB-DDW from April 1, 2007, to April 1, 2010.

The source of radon-222 in groundwater in granitic rock aquifers is the decay of radium-226 (a member of the uranium-238 decay series) in aquifer materials. Groundwater in crystalline rocks typically has low radium activities because radium sorbs strongly to mineral surfaces formed during the weathering of feldspars in oxic, low salinity groundwater (Zapecza and Szabo, 1988; Thomas and others, 1993). Ayotte and others (2007) measured greater activities of radon-222 in groundwater from crystalline bedrock aquifers in the northern United States compared to those in aquifers composed of glacial sediments derived from the crystalline bedrock. They attributed the greater radon-222 activities in the crystalline bedrock aquifers to accretion of sorbed radium on fracture surfaces. Similar results have been observed in the Sierra Nevada (fig. 1) and throughout the United States, where concentrations of uranium, radium, and radon-222 in the groundwater were higher in association with granitic aquifer lithology (such as in the BEAR study unit) than other rock types, such as gneiss, sedimentary, metasedimentary, and metavolcanic rocks (Krishnaswami and others, 1982; Vinson and others, 2009; Fram and Belitz, 2012, 2014; Szabo and others, 2012; figs. 11A, $B$ ). 
$\boldsymbol{A}$

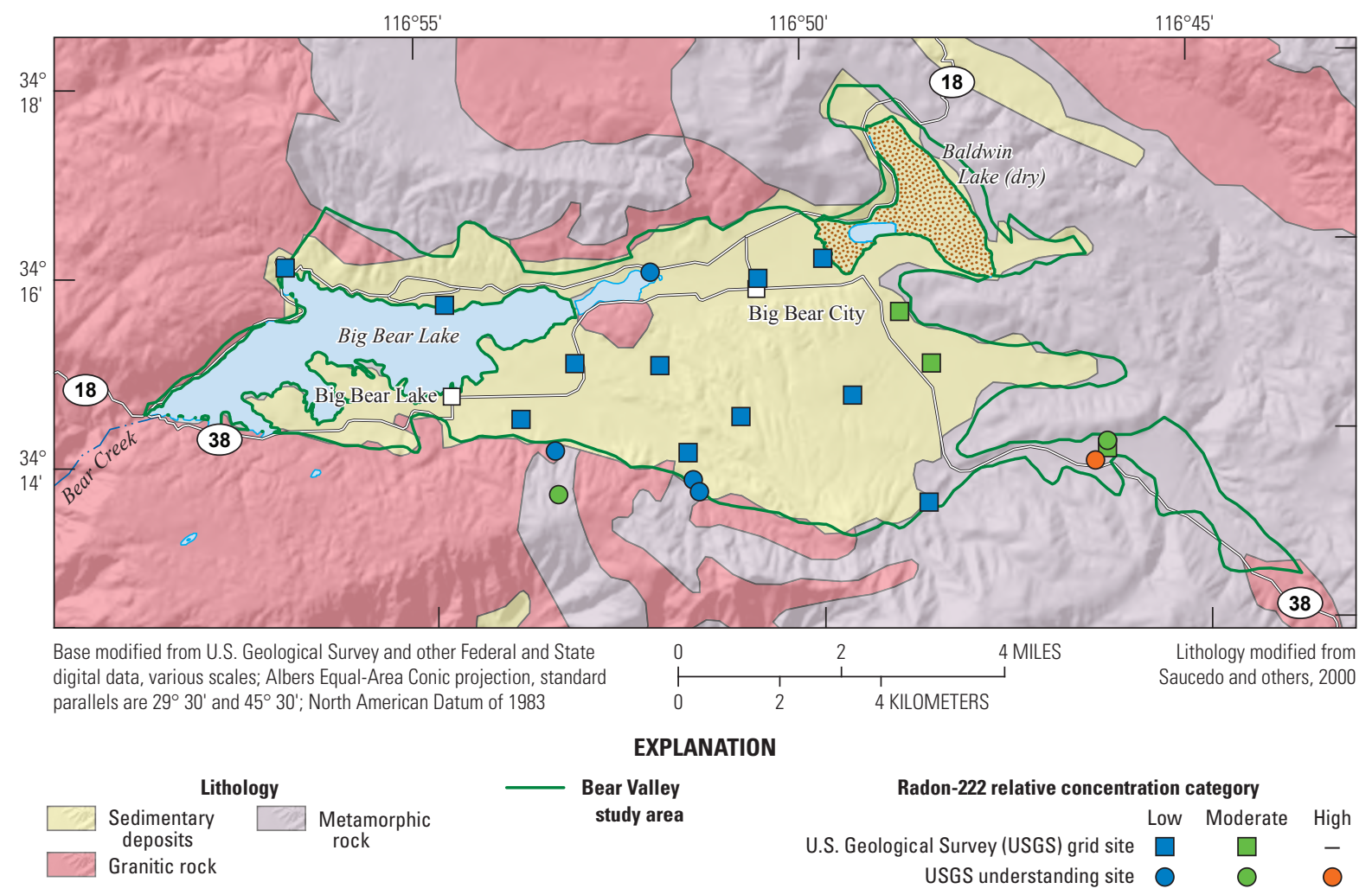

$\boldsymbol{B}$

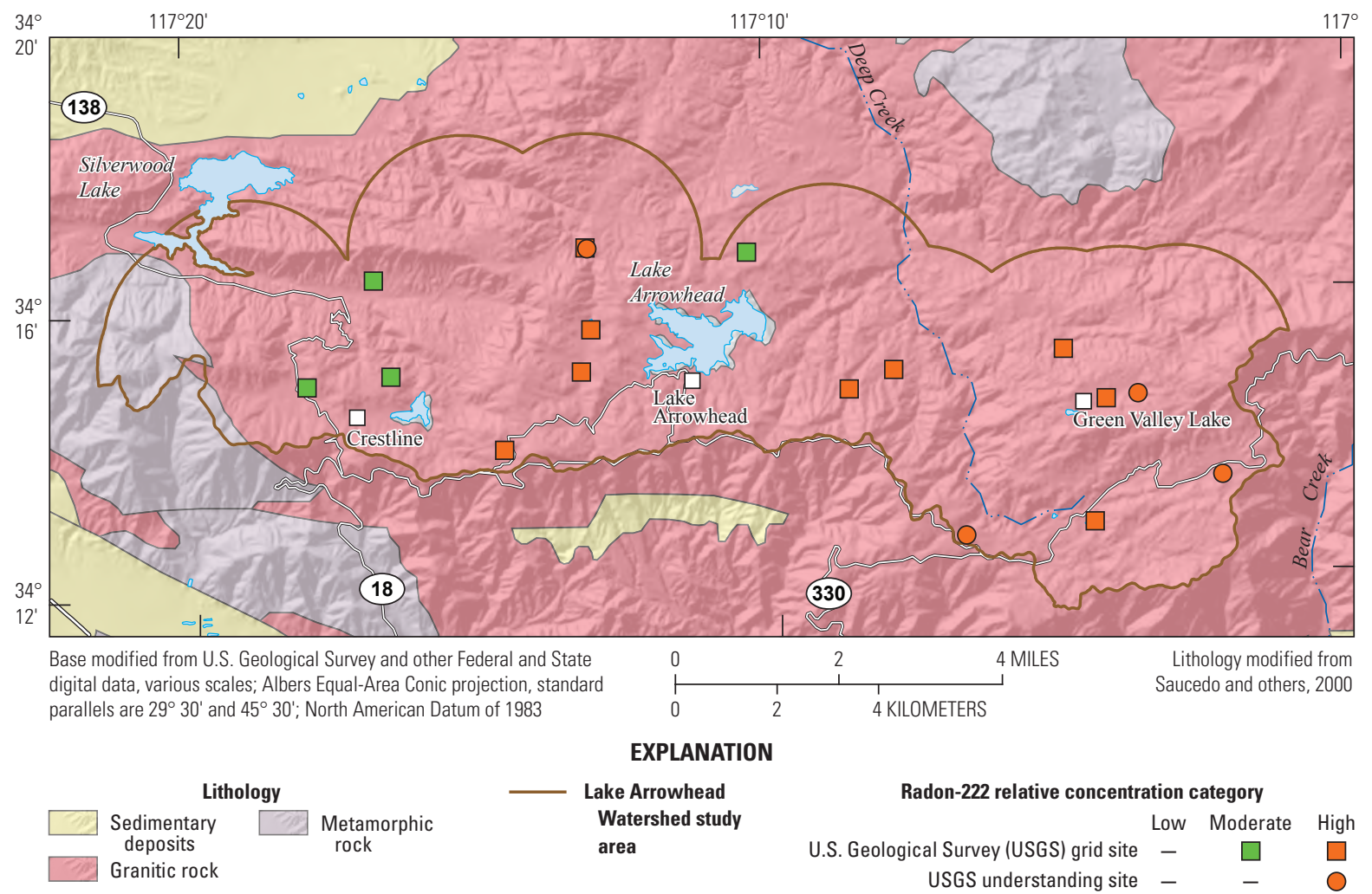

Figure 11. Geologic features and relative concentrations of radon-222 in groundwater samples from U.S. Geological Survey (USGS) grid and understanding sites in two study areas of the California Groundwater Ambient Monitoring and Assessment (GAMA) Priority Basin Project, 2010: $A$, Bear Valley and B, Lake Arrowhead Watershed. 
Previous studies in the San Bernardino Mountains also showed the relationship between crystalline granitic rocks and elevated uranium and radon-222 in groundwater (U.S. Geological Survey, 1961; California Department of Public Health, 2003). The granitic rock formations in the San Bernardino Mountains (including the BEAR study unit) have been found to contain uranium concentrations in amounts greater than the crustal average and, therefore, are the probable source of elevated radon-222 activities in soil gas and groundwater (California Department of Public Health, 2003). Specifically, in the LAW study area, a study by the USGS (in cooperation with the Lake Arrowhead Community Service District) in 2008-09 found that the high activities of radon-222 (4,500-34,200 $\mathrm{pCi} / \mathrm{L})$ in groundwater, compared to the low activities in surface water, could be used as a tracer of groundwater discharge to Lake Arrowhead (Robert Anders, U.S. Geological Survey, written commun., 2014).

Moderate RCs of radon-222 were found in groundwater from three USGS grid sites in the BV study area where there was evidence of a metamorphic rock lithology in the perforation interval (appendix table 1-1). Previous studies by the USGS and others have associated elevated activities of radon-222 not only with granitic rocks, but also with metamorphic rocks (Otton, 1992; Wood and others, 2004; Harden and others, 2009). The activity of radon-222 at the USGS grid sites in the BV study area was most likely due to groundwater interacting with metamorphic rocks in the primary aquifer system. Similarly, samples from three USGS understanding sites also had high and moderate RCs of radon-222, and there was evidence of a metamorphic rock lithology in the perforation interval (fig. 11A; appendix table 1-1).

\section{Understanding Assessment for Uranium and Gross Alpha Radioactivity}

Sources of uranium to groundwater include dissolution of uranium-bearing minerals, such as uraninite, zircon, and titanite, and desorption of uranium from mineral surfaces in the presence of bicarbonate (Hem, 1985; Jurgens and others, 2009). Chronic exposure to uranium in drinking water at concentrations greater than the MCL-US or the MCL-CA can result in chronic toxic effects to the kidneys or increased cancer risks (U.S. Environmental Protection Agency, 2009a).

Wilcoxon rank-sum tests showed that uranium concentrations in groundwater were greater at USGS grid sites in the LAW study area than at USGS grid sites in the BV study area (table 5; figs. $12 A, B$ ). In the LAW study area, uranium was present at high RCs in 26 percent of the primary aquifer system and at moderate RCs in 43 percent (table 7). Nearly all high and moderate RCs of gross alpha radioactivity in the SWRCB-DDW database were also from the LAW study area. Uranium and gross alpha radioactivity were significantly correlated (Spearman's rho $=0.80, p=0.001$ ) and close to the linear correlation line (fig. 13). This indicates that most of the gross alpha radioactivity was from uranium and that other potential sources of gross alpha radioactivity, like radium, were not significant. There were no total radium data in the SWRCB-DDW database for the BEAR study unit, and all radium-228 activities were at low relative concentrations (http://www.waterboards.ca.gov/gama/geotracker_gama. shtml). Close relations between uranium and gross alpha radioactivity were confirmed by an aquifer-scale proportion of high RCs of adjusted gross alpha radioactivity in less than 2 percent of the primary aquifer system of the LAW study area (table 7). Because uranium and gross alpha radioactivity are so closely correlated, and the USGS did not measure gross alpha radioactivity, the understanding assessment is presented only for uranium.

Fractured granitic rocks, like those that form the primary aquifer system in the LAW study area, commonly contain uranium-bearing minerals that can dissolve in groundwater (Hem, 1985). The movement of groundwater dissolves uranium and either transports it in fractures in the granitic rocks or in fractures and porous zones in formations adjacent to the granitic rock formations (California Department of Public Health, 2003). In contrast, the sedimentary deposits that make up the primary aquifer system in the BV study area were derived chiefly from metamorphic rocks of the surrounding mountains and commonly do not contain abundant uraniumbearing minerals (Klepper and Wyant, 1957; California Department of Public Health, 2003).

Uranium concentrations were significantly inversely correlated with activities of tritium in groundwater samples from the USGS grid and understanding sites in the LAW study area (fig. 14; Spearman's rho $=-0.634, p=0.011$ ). Tritium is a radioactive isotope of hydrogen that is formed in the upper atmosphere and becomes part of atmospheric water molecules, thereby entering the hydrologic cycle. The tritium decays over time; therefore, its concentration can be used to estimate the time since water fell as precipitation. As discussed in the "Groundwater Age" section, groundwater with tritium concentrations greater than 2.0 TUs is largely composed of water recharged in the last 60 years (modern age), and groundwater with tritium concentrations less than $2.0 \mathrm{TU}$ is a mixture of modern recharge and water recharged hundreds to thousands of years ago (mixed and pre-modern ages). Wilcoxon rank-sum tests showed that uranium concentrations were significantly greater in groundwater samples from USGS grid and understanding sites classified as mixed or pre-modern age than from sites with groundwater classified as modern age ( $p=0.035, Z=2.103$; fig. 14; appendix table 1-3). High RCs of uranium were found only in groundwater that contained this ancient recharge and had granitic rock aquifer lithology, indicating that dissolution of the uranium-bearing minerals requires long contact time with groundwater. 
$\boldsymbol{A}$

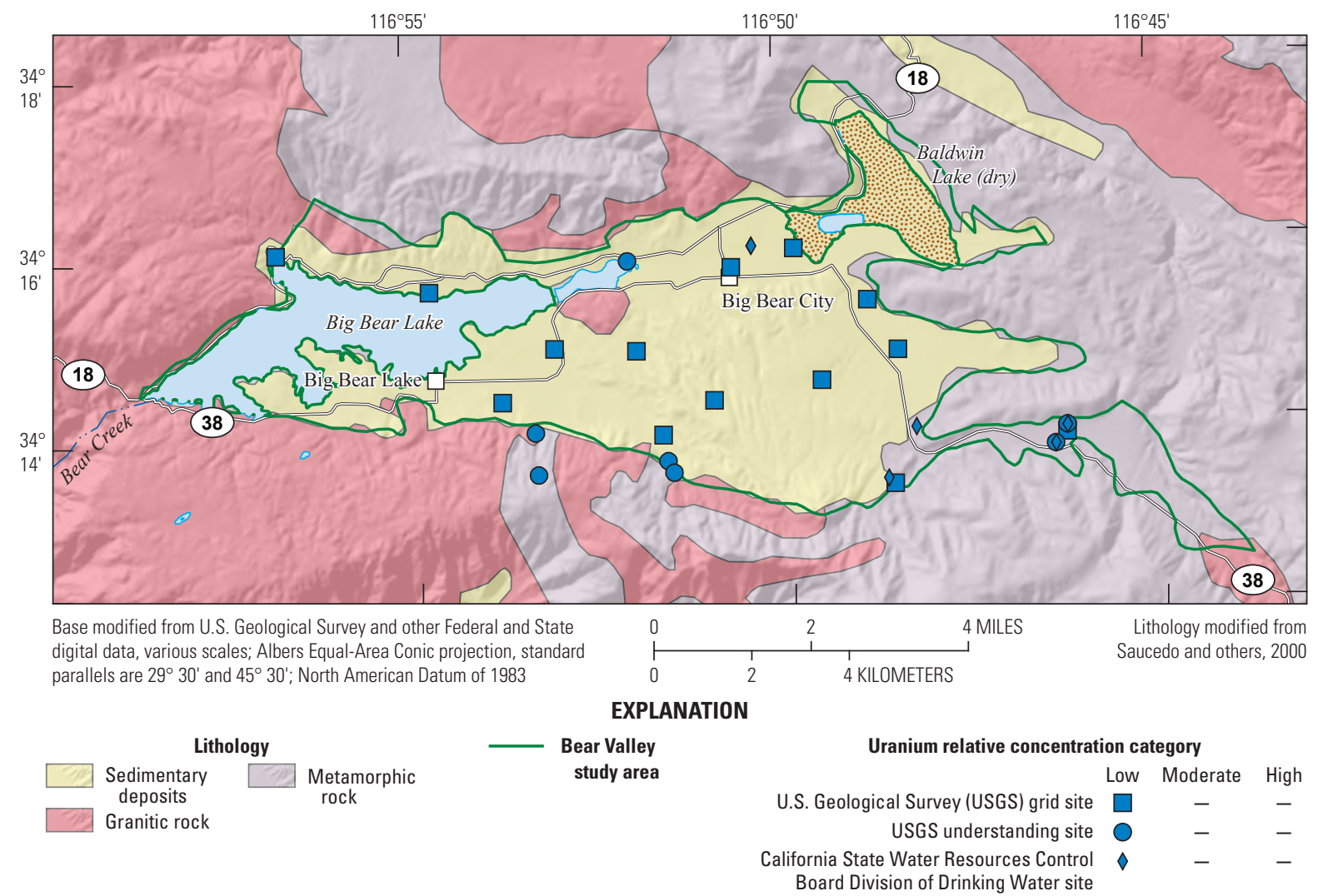

$B$

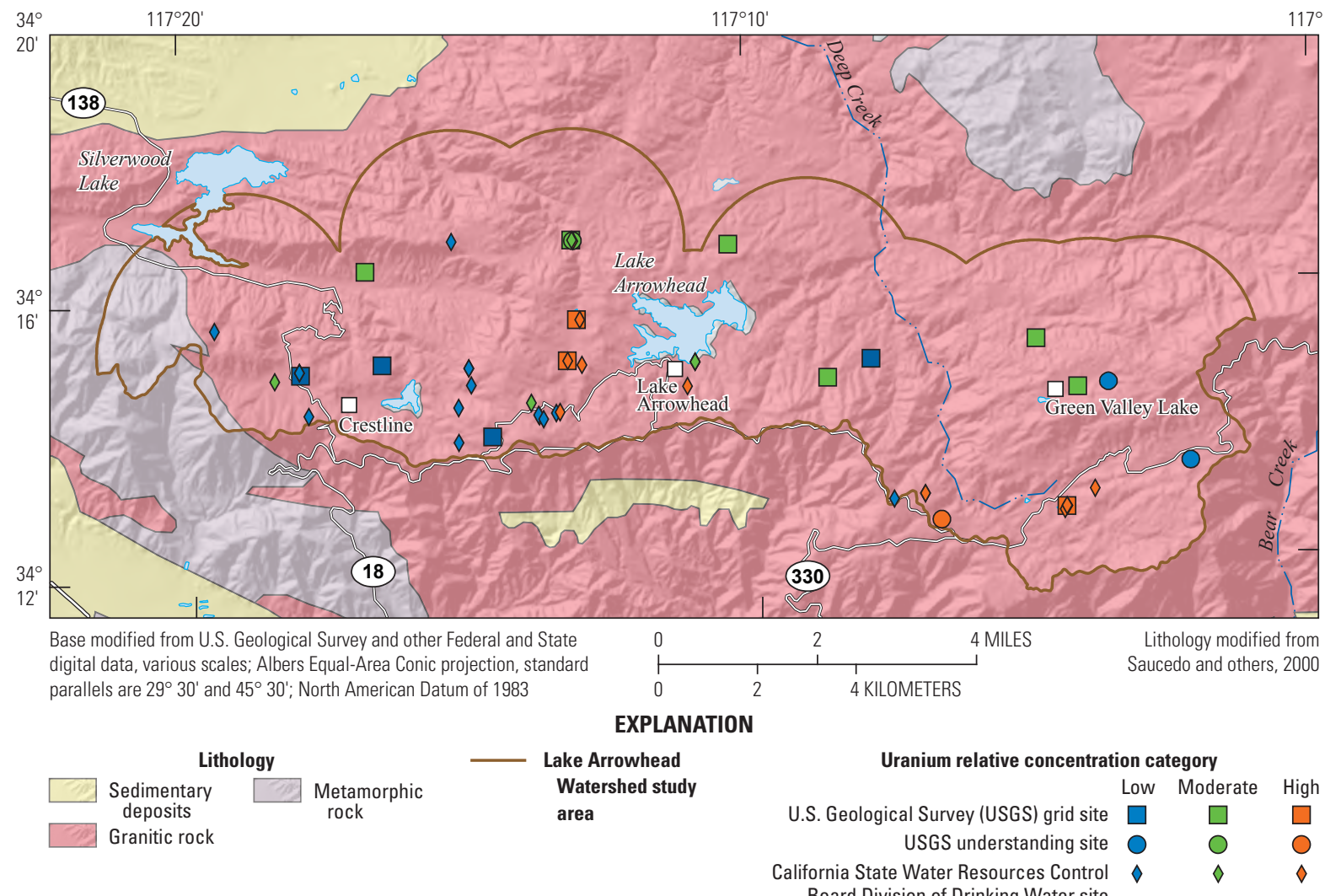

Figure 12. Geologic features and relative concentrations of uranium in groundwater samples from U.S. Geological Survey (USGS) grid and understanding sites (2010) and from California Division of Drinking Water (SWRCB-DDW) sites (April 1, 2007-April 1, 2010) in two study areas of the California Groundwater Ambient Monitoring and Assessment (GAMA) Priority Basin Project: $A$, Bear Valley and $B$, Lake Arrowhead Watershed. 


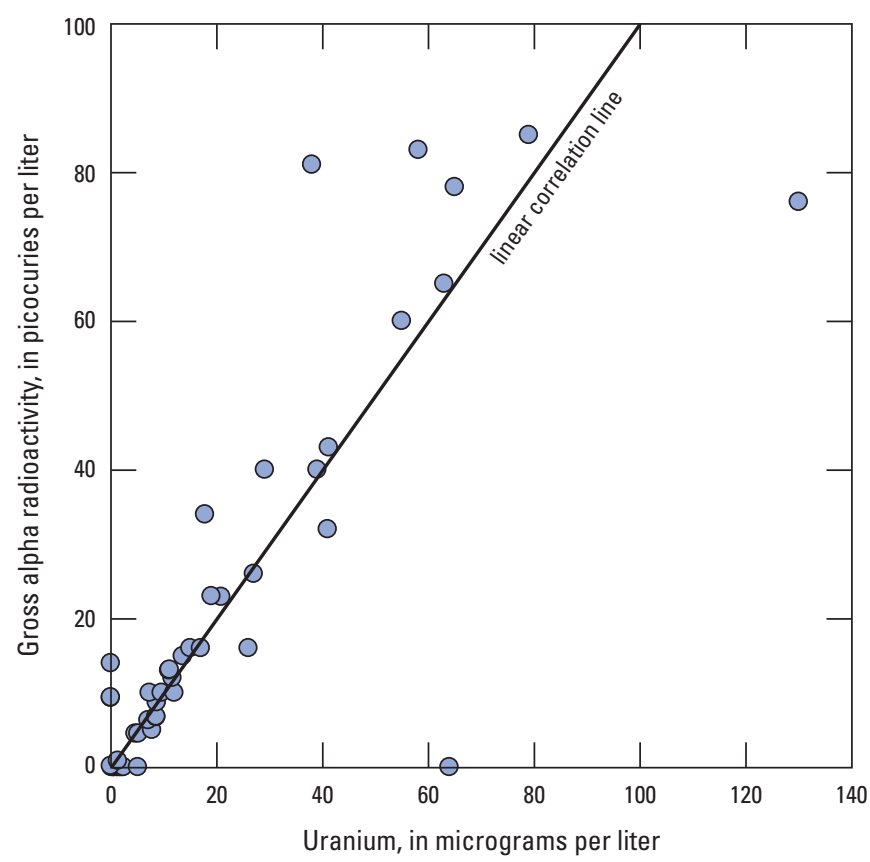

Figure 13. Relation of uranium concentration to unadjusted gross alpha radioactivity in groundwater samples from the California Division of Drinking Water (SWRCB-DDW) sites (April 1, 2007-April 1, 2010) in the Bear Valley and Lake Arrowhead Watershed study unit, California Groundwater Ambient Monitoring and Assessment (GAMA) Priority Basin Project.

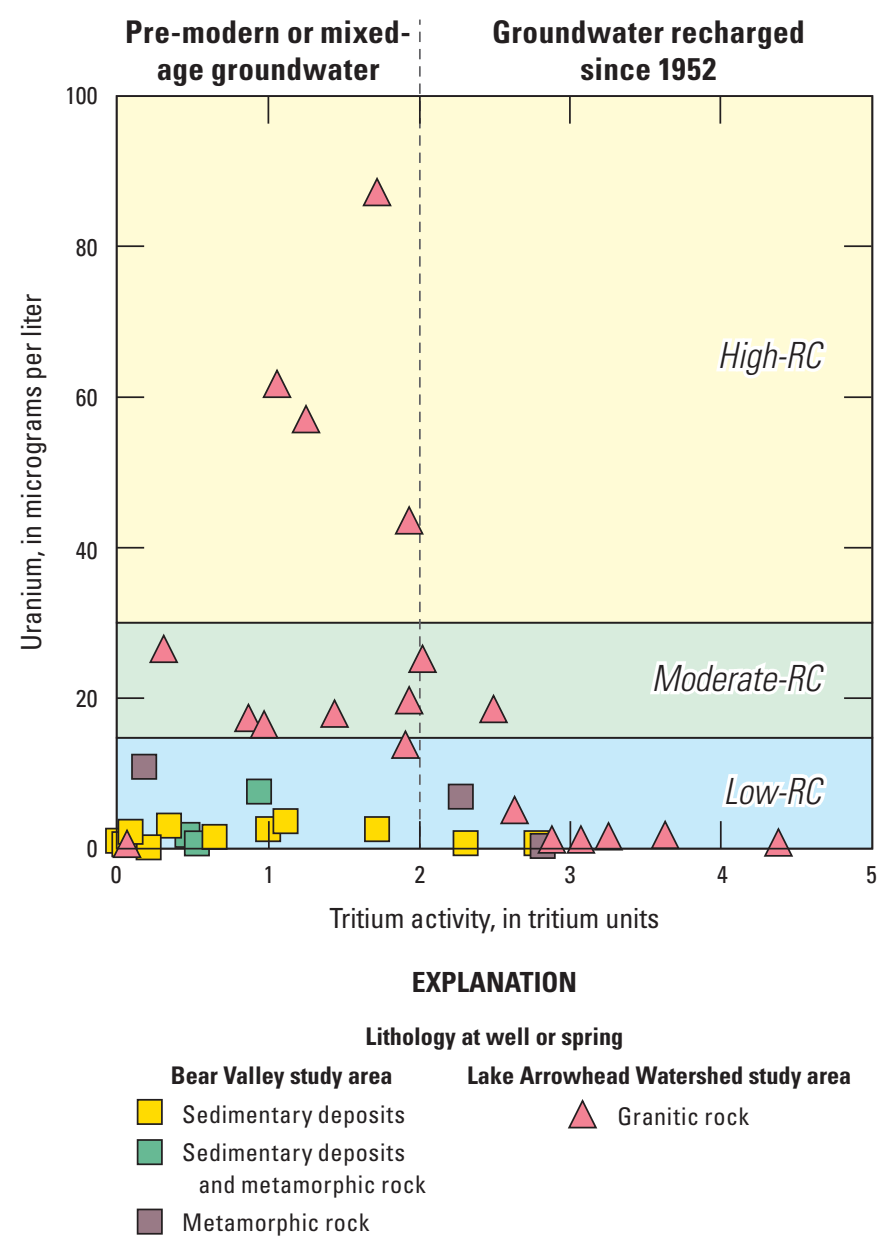

Figure 14. Relations of uranium concentration to tritium activity in groundwater, aquifer lithology, and study area of U.S. Geological Survey (USGS) grid and understanding sites sampled in the Bear Valley and Lake Arrowhead Watershed study unit, 2010, California Groundwater Ambient Monitoring and Assessment (GAMA) Priority Basin Project. 


\section{Trace Elements}

Trace elements were detected in the BV study area at high RCs in 9.0 percent of the primary aquifer system, moderate RCs in 7.1 percent, and low RCs in 84 percent (table 6). Fluoride and arsenic were the only trace elements present at high or moderate RCs (table 7). Trace elements were not present at high RCs in the primary aquifer system of the LAW study area, but they were found at moderate RCs in 3.2 percent (table 6). Detections of lead in groundwater samples from the SWRCB-DDW sites accounted for the moderate RCs of trace elements in the LAW study area (table 7).

\section{Understanding Assessment for Fluoride}

Fluoride is the anionic form of the element fluorine. Natural sources of fluoride in groundwater include dissolution of fluoride-bearing minerals, such as fluorite and fluorapatite (Hem, 1985). Fluorite, a common fluorine mineral with low solubility, is found in igneous, metamorphic, and sedimentary rocks (Flanagan and others, 2012). Elevated concentrations of fluoride, arsenic, and boron have been found in geothermal waters and in closed, arid basins (Smedley and Kinniburgh, 2002). The main anthropogenic source of fluoride in water is addition of sodium fluoride or hexafluorosilicic acid during drinking-water treatment as a public health measure to reduce dental caries (National Research Council, 2006). Hexafluorosilicic acid is a byproduct of the manufacture of phosphate fertilizers and hydrofluoric acid and of processing aluminum ore. Chronic exposure to drinking water with fluoride concentrations in drinking water greater than the MCL-CA of 2.0 milligrams per liter $(\mathrm{mg} / \mathrm{L})$ can result in bone disease and tooth discoloration (National Research Council, 2006). Fluoride was present at high RCs in 5.4 percent and moderate RCs in 3.6 percent of the primary aquifer system in the BV study area, but was only present at low RCs in the LAW study area (table 7).

Previous groundwater studies by the USGS found elevated concentrations of fluoride associated with geothermal activity (Nordstrom and Jenne, 1977; Smedley and Kinniburgh, 2002). Elevated fluoride concentrations were found at many SWRCB-DDW sites in the northeastern part of the BV study area, which has been attributed to the effect of Pan Hot Springs on the aquifer system (Previtali, 2002; fig. 15A). Fluoride concentrations in the Pan Hot Springs area vary between the wet and dry seasons, such that concentrations are higher during the summer drawdowns of wells, concentrations are lower in the winter as a result of groundwater recharge and blending of natural waters, and the annual average concentration ranges from 1.3 to $4.0 \mathrm{mg} / \mathrm{L}$ (Previtali, 2002). Fluoride was detected at a high RC in the sample from the USGS grid site in the Pan Hot Springs area (fig. 15A). This USGS grid site is also a SWRCB-DDW site, and historical data indicate high and moderate RCs of fluoride have been measured for decades. The SWRCB-DDW database indicates that this USGS grid site was sampled 287 times for fluoride from 1987 to 2006, and the median concentration was $2.6 \mathrm{mg} / \mathrm{L}$ (http://www.waterboards.ca.gov/gama/geotracker_ gama.shtml). In addition, the USGS collected seven waterquality samples at this USGS grid site from 2005 to 2006 at the well discharge pipe and at various depths in the perforated interval, and fluoride concentrations ranged from 9.33 to $16.7 \mathrm{mg} / \mathrm{L}$ (Flint and Martin, 2012).

Fluoride was detected at a high RC at a USGS grid site in the southeastern part of the BV study area (fig. 15A). This site is also a SWRCB-DDW site and is known by regional water agencies to have fluoride concentrations greater than the MCL-US (City of Big Bear Lake, 2010). This USGS grid site is only used by the water purveyors when the produced groundwater can be immediately blended with groundwater from a nearby SWRCB-DDW site to reduce fluoride concentrations to low levels. The SWRCB-DDW database indicates this USGS grid site was sampled for fluoride in 2002 and 2005, and concentrations were 2.6 and $2.8 \mathrm{mg} / \mathrm{L}$, respectively (http://www.waterboards.ca.gov/gama/ geotracker_gama.shtml).

Fluoride was detected at a moderate RC at a USGS grid site in the northwestern part of the BV study area (fig. 15A). Available data for this site indicate that historically low RCs have been steadily increasing with time (http://www. waterboards.ca.gov/gama/geotracker_gama.shtml). The SWRCB-DDW database indicates that during the historical period this USGS grid site was sampled for fluoride in 1996, 2002 , and 2005, and concentrations were $0.10,0.81$, and $1.0 \mathrm{mg} / \mathrm{L}$, respectively.

Reaction times between groundwater and minerals in aquifer materials with sedimentary lithology have been shown to be an important component for controlling fluoride accumulation (Edmunds and Smedley, 2013). Fluoride concentrations and tritium activities were compared to assess the potential role of groundwater age and longer reaction times relative to fluoride accumulation in the BEAR study unit. Concentrations of fluoride in USGS grid and understanding sites were significantly inversely correlated with activities of tritium (Spearman's rho $=-0.416, p=0.011$; fig. 16). Specifically, groundwater was classified as pre-modern at the USGS grid site near Pan Hot Springs, where samples had a high RC of fluoride, and at the USGS grid site where samples had a moderate $\mathrm{RC}$, and groundwater of mixed age at another USGS grid site had a high RC of fluoride. These findings indicated that reaction times with sedimentary aquifer minerals do play a role in the accumulation of fluoride in the primary aquifer system, although geothermal activity has been shown to have the largest effect on fluoride concentrations in the study unit. 


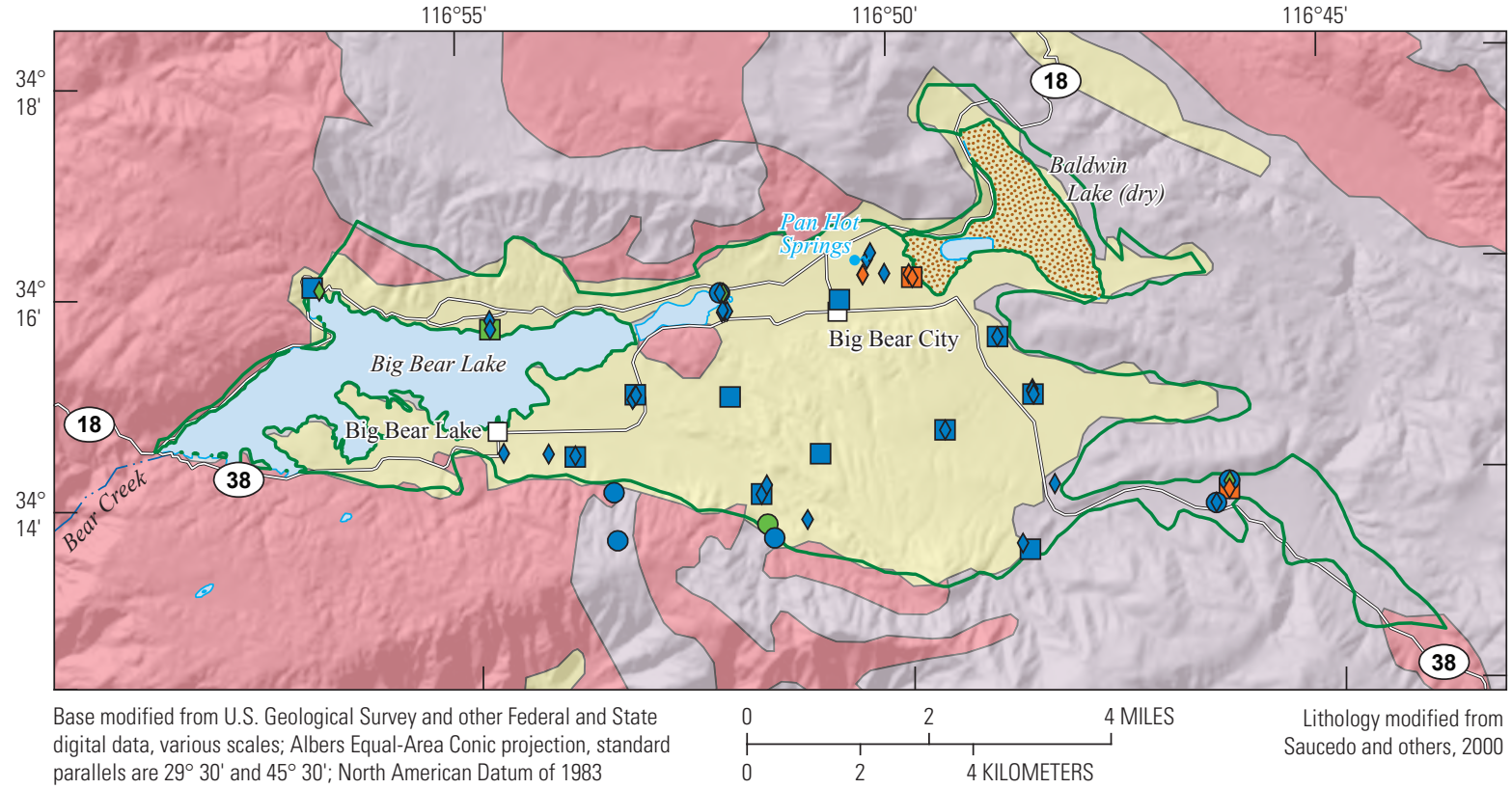

\section{EXPLANATION}

\begin{tabular}{|c|c|c|c|c|c|c|c|}
\hline \multicolumn{2}{|c|}{ Lithology } & - & \multirow{2}{*}{$\begin{array}{l}\text { Bear Valley } \\
\text { study area }\end{array}$} & \multicolumn{4}{|c|}{ Fluoride relative-concentration category } \\
\hline Sedimentary & Metamorphic & & & & Low & Moderate & High \\
\hline $\begin{array}{l}\text { deposits } \\
\text { Granitic rock }\end{array}$ & rock & & Spring & $\begin{array}{l}\text { U.S. Geological Survey (USGS) grid site } \\
\text { USGS understanding site }\end{array}$ & $\square$ & $\begin{array}{l}\square \\
0\end{array}$ & $\begin{array}{l}\square \\
-\end{array}$ \\
\hline & & & & $\begin{array}{l}\text { California State Water Resources Control } \\
\text { Board Division of Drinking Water site }\end{array}$ & $\diamond$ & $\diamond$ & $\Delta$ \\
\hline
\end{tabular}

B

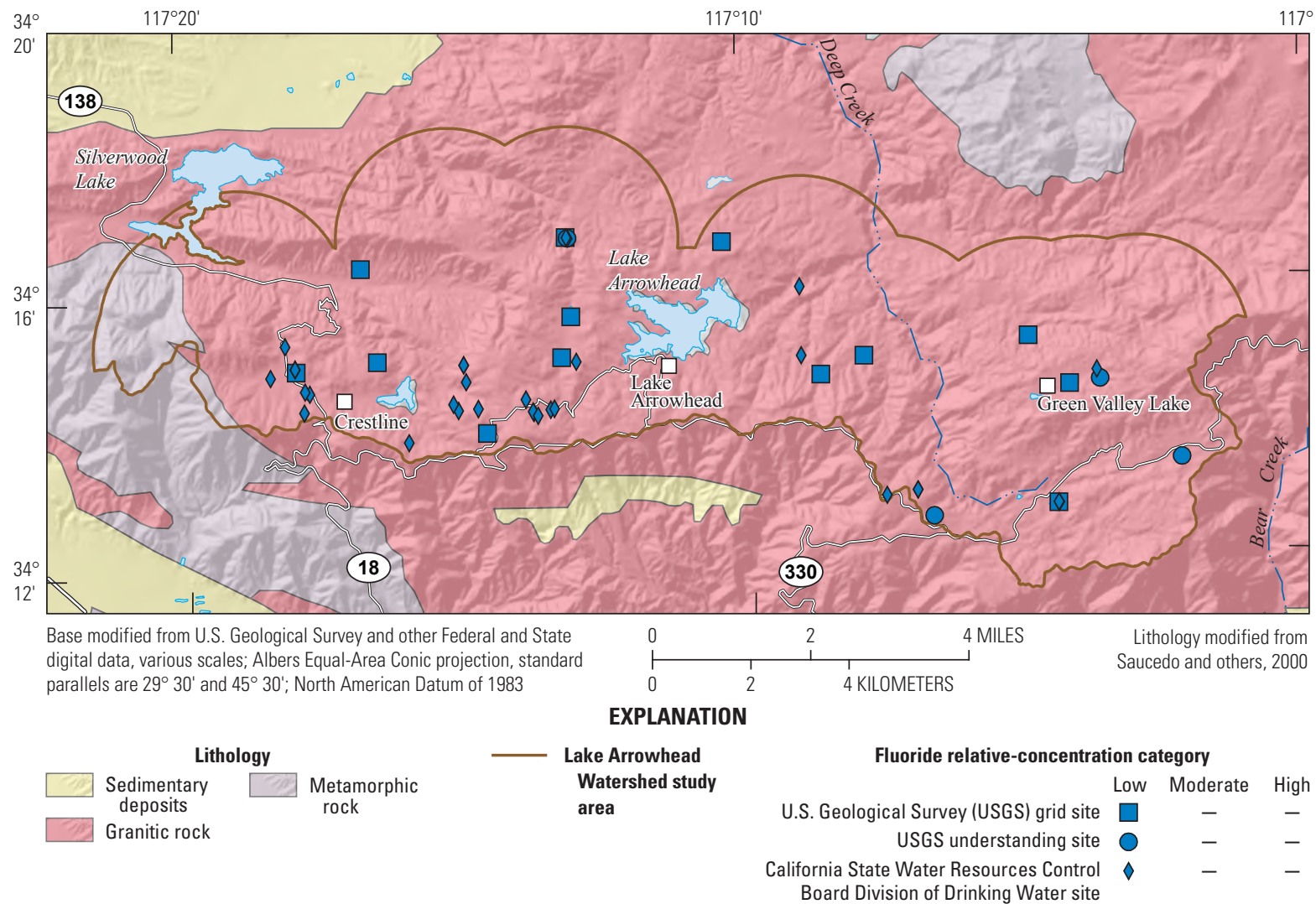

Figure 15. Geologic features and relative concentrations of fluoride in groundwater samples from U.S. Geological Survey (USGS) grid and understanding sites (2010) and from California Division of Drinking Water (SWRCB-DDW) sites (April 1, 2007-April 1, 2010) in two study areas of the California Groundwater Ambient Monitoring and Assessment (GAMA) Priority Basin Project: A, Bear Valley and $B$, Lake Arrowhead Watershed. 

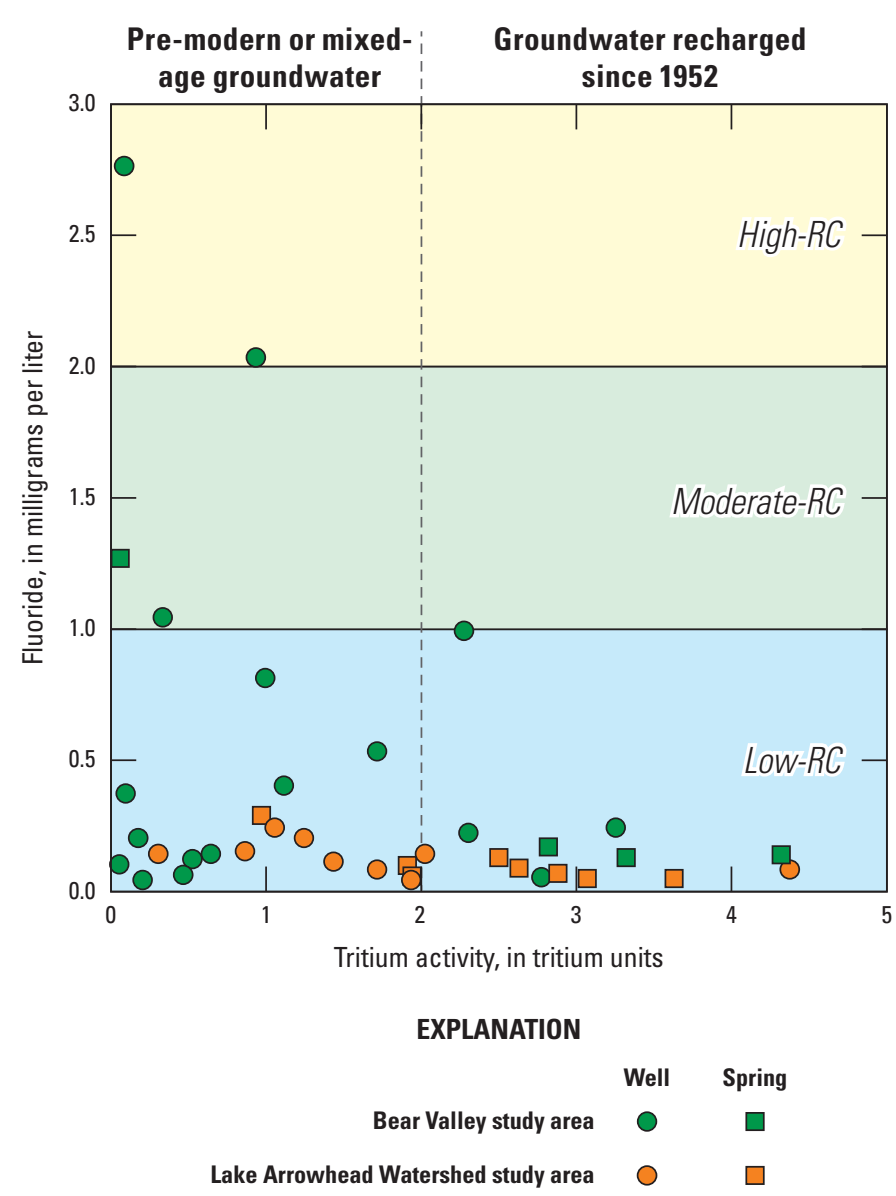

Figure 16. Relation of fluoride concentration to tritium activity in groundwater samples from U.S. Geological Survey (USGS) grid sites in the Bear Valley and Lake Arrowhead Watershed study unit, 2010, California Groundwater Ambient Monitoring and Assessment (GAMA) Priority Basin Project.

\section{Understanding Assessment for Arsenic}

Arsenic is a semi-metallic element naturally present in trace amounts. Sources of arsenic in groundwater are natural or anthropogenic. Natural sources include the dissolution of arsenic-bearing minerals, desorption of arsenic from mineral surfaces, and geothermal waters. Potential anthropogenic sources of arsenic include mining of copper and gold ores, coal combustion, arsenical pesticides, arsenical veterinary pharmaceuticals, and wood preservatives (Welch and others, 1988). The MCL-US for arsenic was lowered from 50 to 10 micrograms per liter $(\mu \mathrm{g} / \mathrm{L})$ in 2002 , and chronic exposure to arsenic concentrations between 10 and $50 \mu \mathrm{g} / \mathrm{L}$ in drinking water has been linked to increased cancer risk and to noncancerous effects including skin damage and circulatory problems (U.S. Environmental Protection Agency, 2015a). Arsenic was detected at a concentration greater than the
MCL-US in water from only one USGS grid site, which was in the BV study area (figs. 17A, $B$ ).

Elevated arsenic concentrations in groundwater typically are not related to high arsenic concentrations in aquifer sediments or rock, but rather to geochemical conditions that enhance arsenic solubility and hydrologic conditions that favor arsenic accumulation in groundwater (Smedley and Kinniburgh, 2002). Commonly, arsenic concentrations are positively correlated with $\mathrm{pH}$ as a result of desorption of arsenic from aquifer sediments, a process intensified by highter $\mathrm{pH}$ (Belitz and others, 2003; Welch and others, 2006). Another mechanism to which elevated arsenic concentrations in groundwater are attributed is the release of arsenic from dissolution of iron or manganese oxides under iron- or manganese-reducing (anoxic) conditions (Welch and others, 2000, 2006; Frankenberger, 2002). Elevated concentrations of arsenic in groundwater have also been associated with long residence times in aquifer systems (Smedley and Kinniburgh, 2002). The USGS grid sample in which a high $\mathrm{RC}$ of arsenic was measured had the highest $\mathrm{pH}$ value (9.1) among groundwater samples in the BEAR study unit and was also the only sample where redox conditions were anoxic (suboxic) (appendix table 1-4). This USGS grid site (BEAR-S04) has groundwater that was pre-modern in age, had the oldest carbon-14-based age (appendix table 1-3), and also had a moderate RC of fluoride, which was most likely related to long groundwater residence time in the primary aquifer system.

\section{Nutrients}

Nutrients were not detected at high RCs in the primary aquifer systems of the BEAR study unit (table 6). Moderate RCs of nutrients were found in 1.8 percent and 2.7 percent of the primary aquifer systems in the BV and LAW study areas, respectively (table 6). The only nutrient detected at a moderate $\mathrm{RC}$ in either study area was nitrate (table 7). Nitrate in groundwater has anthropogenic and natural sources; however, concentrations of nitrate greater than about $1.0 \mathrm{mg} / \mathrm{L}$ (corresponding to an RC of 0.1) generally are the result of anthropogenic inputs (Nolan and Hitt, 2003; Dubrovsky and others, 2010).

\section{Inorganic Constituents with Aesthetic-Based Benchmarks}

The class of constituents with aesthetic-based benchmarks includes salinity indicators and several trace metals that are common in groundwater. The only constituents present at high RCs with SMCL benchmarks were iron and manganese. Iron, manganese, or both were present at high RCs in 3.1 percent and 23 percent of the of the primary aquifers systems in the BV and LAW study areas, respectively (table 6). Salinity indicators (TDS, sulfate, chloride) were only found at low RCs. 


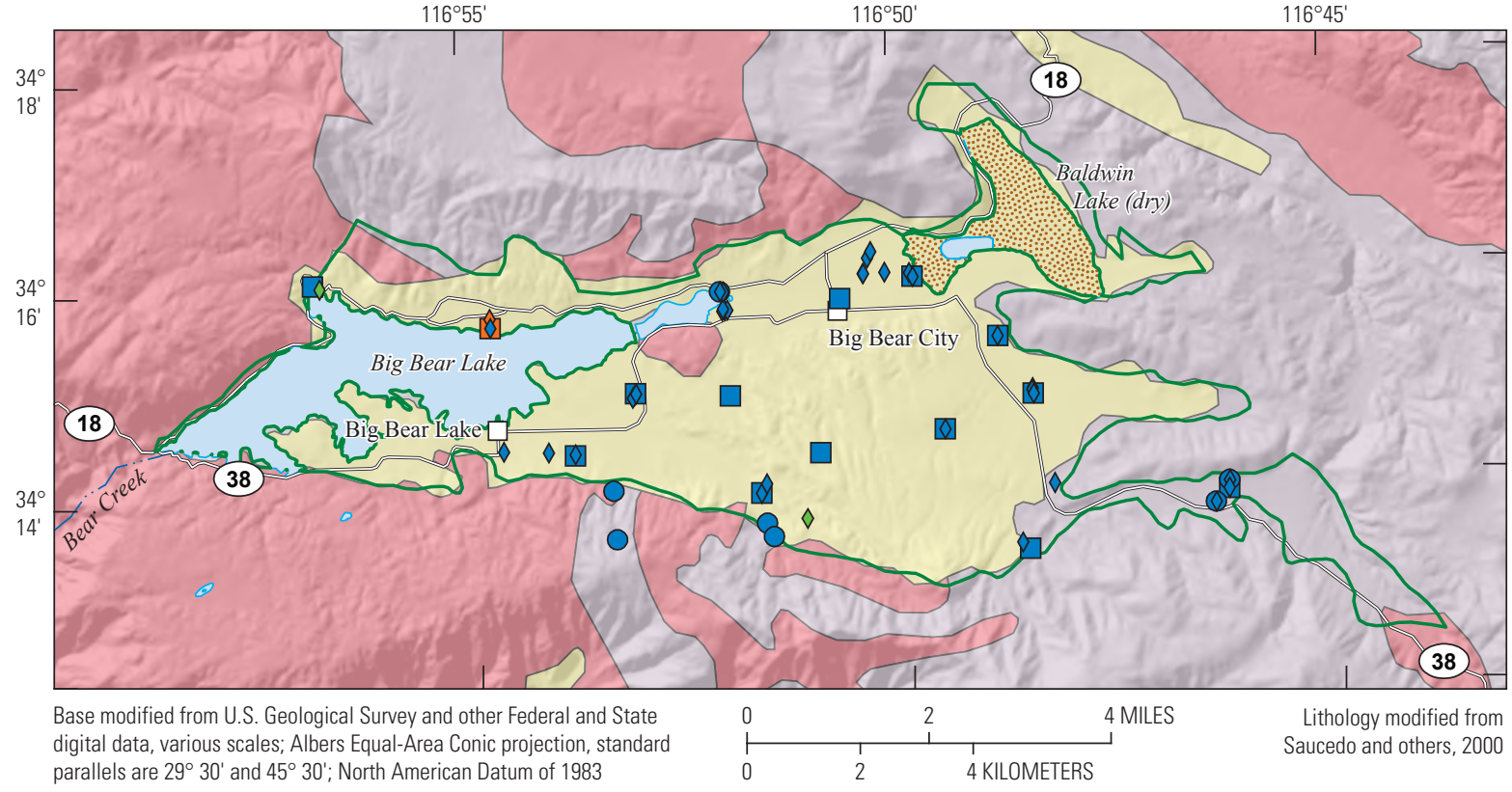

\section{EXPLANATION}

\begin{tabular}{|c|c|c|}
\multicolumn{1}{c}{ Lithology } \\
Sedimentary \\
deposits \\
Granitic rock
\end{tabular}

Bear Valley

study area
Arsenic relative-concentration category

Low Moderate High

U.S. Geological Survey (USGS) grid site USGS understanding site

California State Water Resources Control Board Division of Drinking Water site

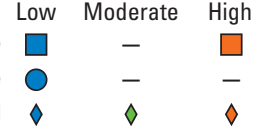

B

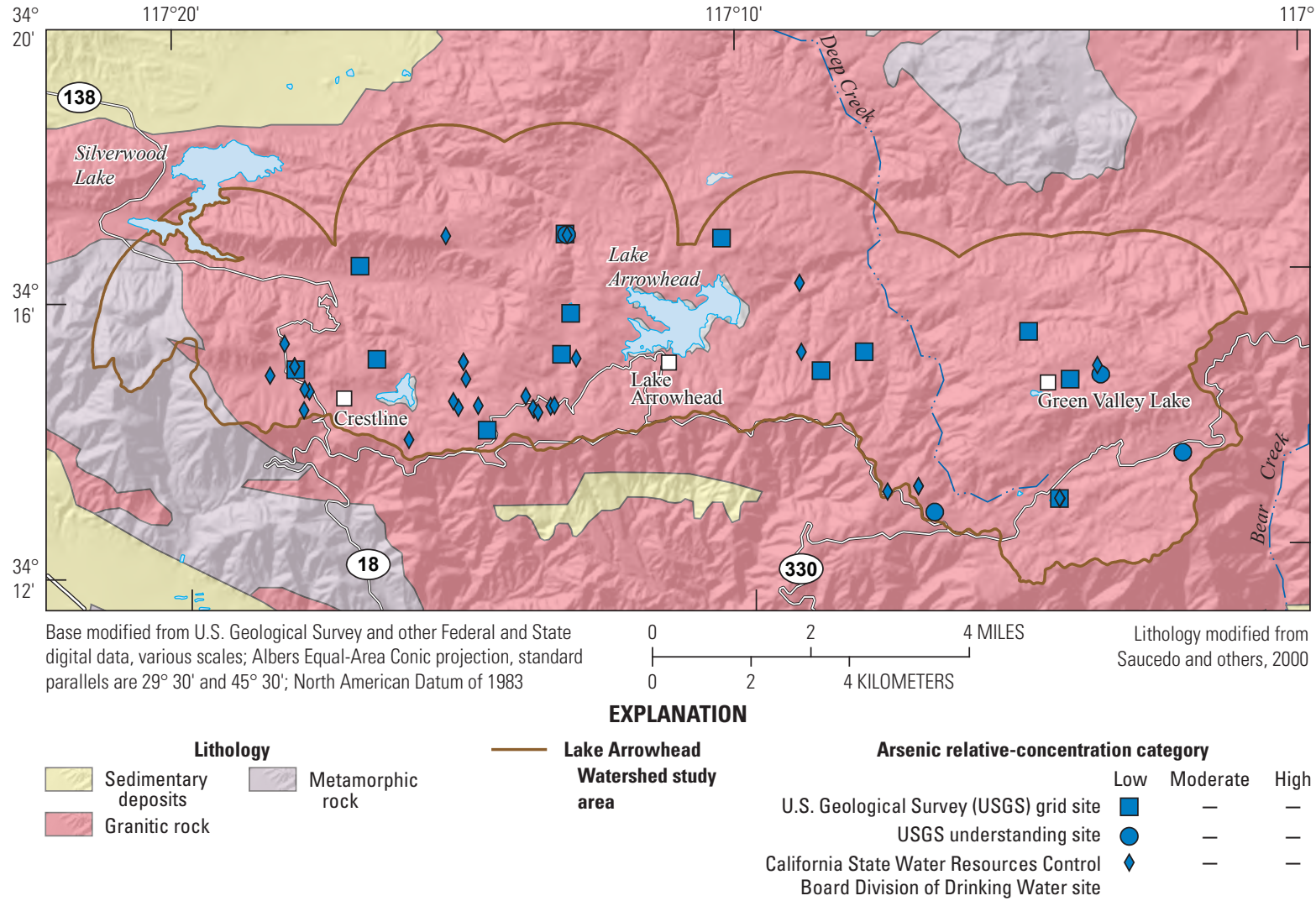

Figure 17. Geologic features and relative concentrations of arsenic in groundwater samples from U.S. Geological Survey (USGS) grid and understanding sites (2010) and California Division of Drinking Water (SWRCB-DDW) sites (April 1, 2007-April 1, 2010) in two study areas of the California Groundwater Ambient Monitoring and Assessment (GAMA) Priority Basin Project: $A$, Bear Valley and $B$, Lake Arrowhead Watershed. 
Potential natural sources of iron and manganese in groundwater include the weathering and dissolution of igneous and metamorphic rocks as well as the dissolution of various secondary minerals (Hem, 1985) that can be mobilized under reducing conditions (McMahon and Chapelle, 2008). Granitic rocks can contain the minerals biotite, chlorite, magnetite, pyrite, and hornblende, which have significant amounts of iron and manganese. Distributions of iron and manganese concentrations are strongly affected by redox conditions. Under reducing conditions, dissolution of manganese and iron oxides that commonly coat sediment particles increases the mobility of manganese and iron in aquifer systems (Sparks, 1995). The RCs of iron and manganese in water samples from USGS grid sites were high or moderate only in the LAW study area (figs. 10, 18A, $B ; 19 A, B$ ), and Wilcoxon rank-sum tests confirmed that manganese concentrations were significantly greater in samples from USGS grid sites in the LAW study area than in the BV study area (table 5).

High and moderate RCs of iron and manganese were detected only in groundwater from USGS grid sites that had mixed (oxic/anoxic Mn- or Fe-reducing) redox conditions (appendix table 1-4). Additionally, the median DO concentration for these groundwater samples with high and moderate RCs of $\mathrm{Mn}$ or $\mathrm{Fe}$ was $1.2 \mathrm{mg} / \mathrm{L}$, whereas the median concentration for samples from all other USGS grid sites was $5.1 \mathrm{mg} / \mathrm{L}$. Both of these findings could mean that reductive dissolution is the most productive pathway for the mobilization of iron and manganese in the primary aquifer system. Additionally, groundwater age could be an important factor for accumulation of mobilized iron and manganese in the primary aquifer system. High and moderate RCs of iron and manganese were detected only in samples from USGS grid sites where groundwater was classified as mixed age (appendix table 1-3). High and moderate RCs of iron or manganese were also present in samples of pre-modern groundwater with mixed-redox conditions and low DO concentrations from two USGS understanding sites.

\section{Organic and Special-Interest Constituents}

Two classes of organic constituents with health-based benchmarks were assessed in this study: volatile organic compounds (VOCs) and pesticides and pesticide degradates. The VOCs are present in paints, solvents, fuels, refrigerants, and fumigants or can be formed as byproducts of water disinfection. These organic constituents are characterized by a volatile nature, or tendency to evaporate, and they generally persist longer in groundwater than in surface water because groundwater is isolated from the atmosphere (Zogorski and others, 2006). Pesticides include herbicides, insecticides, and fungicides and are used to control unwanted vegetation, insects, fungi, and other pests in agricultural, urban, and suburban settings (Gilliom and others, 2006). The GAMA-PBP included analysis of a large number of organic constituents, many of which were not subject to regulation in California drinking water as of 2016. The USGS-GAMA analytical methods for organic constituents had lower reporting limits than required for compliance with SWRCBDDW regulations for monitoring drinking-water quality (table 2). Of the 168 organic constituents analyzed, 16 were detected at least once (fig. 9), and of these, 14 have either a MCL-US or MCL-CA benchmark (fig. 20), and 2 have a nonregulatory health-based benchmark.

The special-interest constituent class included three chemically unrelated constituents: perchlorate, 1,2,3-trichloropropane (1,2,3-TCP), and $\mathrm{N}$-nitrosodimethylamine (NDMA). At the inception of the GAMA-PBP in 2003, these constituents were of special interest to State of California drinking-water quality agencies because they had recently been detected in groundwater at concentrations that can be relevant to human-health concerns (Belitz and others, 2003). The constituents 1,2,3-TCP and NDMA were not detected in the BEAR study unit's primary aquifer systems. An MCL-CA for perchlorate was established in 2007, and although perchlorate is an inorganic constituent, it was classified as a special-interest constituent in this report to be consistent with other GAMA-PBP reports.

Organic constituents with health-based benchmarks were detected in samples from the BV study area at high RCs in 1.0 percent of the primary aquifer system, moderate RCs in 8.1 percent, and low RCs in 70 percent (table 6). No organic constituents with health-based benchmarks were detected in 21 percent of the BV's primary aquifer system. Organic constituents with health-based benchmarks were not present at high RCs in the LAW study area, but were detected at moderate RCs in 7.7 percent of the primary aquifer system, at low RCs in 46 percent, and were not detected in 46 percent of the primary aquifer system.

\section{Volatile Organic Compounds}

Volatile organic compounds with health-based benchmarks were detected in the BV study area at high RCs in 1.0 percent of the primary aquifer system, at moderate RCs in 8.1 percent, and at low RCs in 70 percent (table 6); and were not detected in 21 percent of the BV's primary aquifer system. In the LAW study area, VOCs with health-based benchmarks were detected at moderate RCs in 7.7 percent of the primary aquifer system, at low RCs in 38 percent; and were not detected in 54 percent of the LAW's primary aquifer system. 


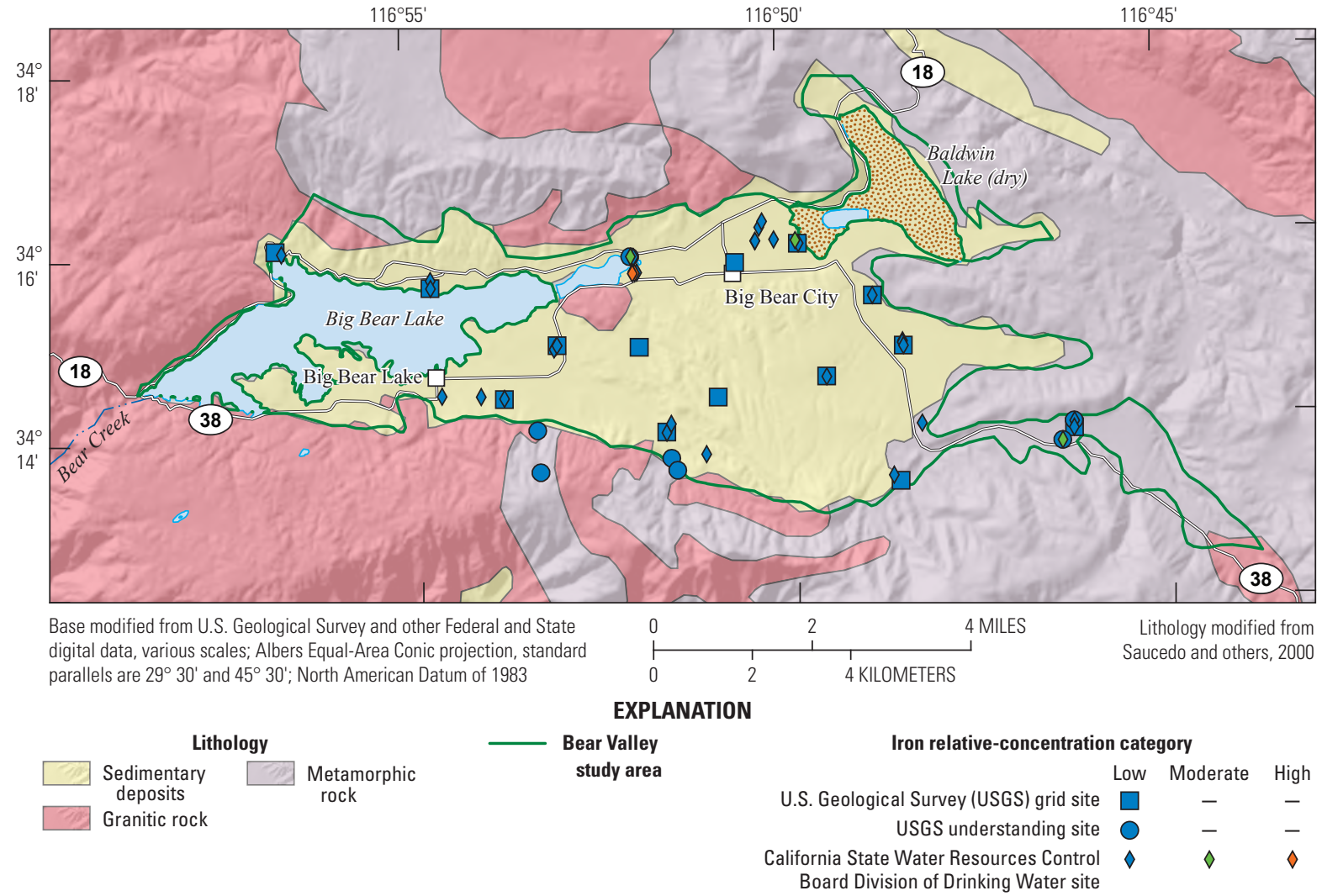

B

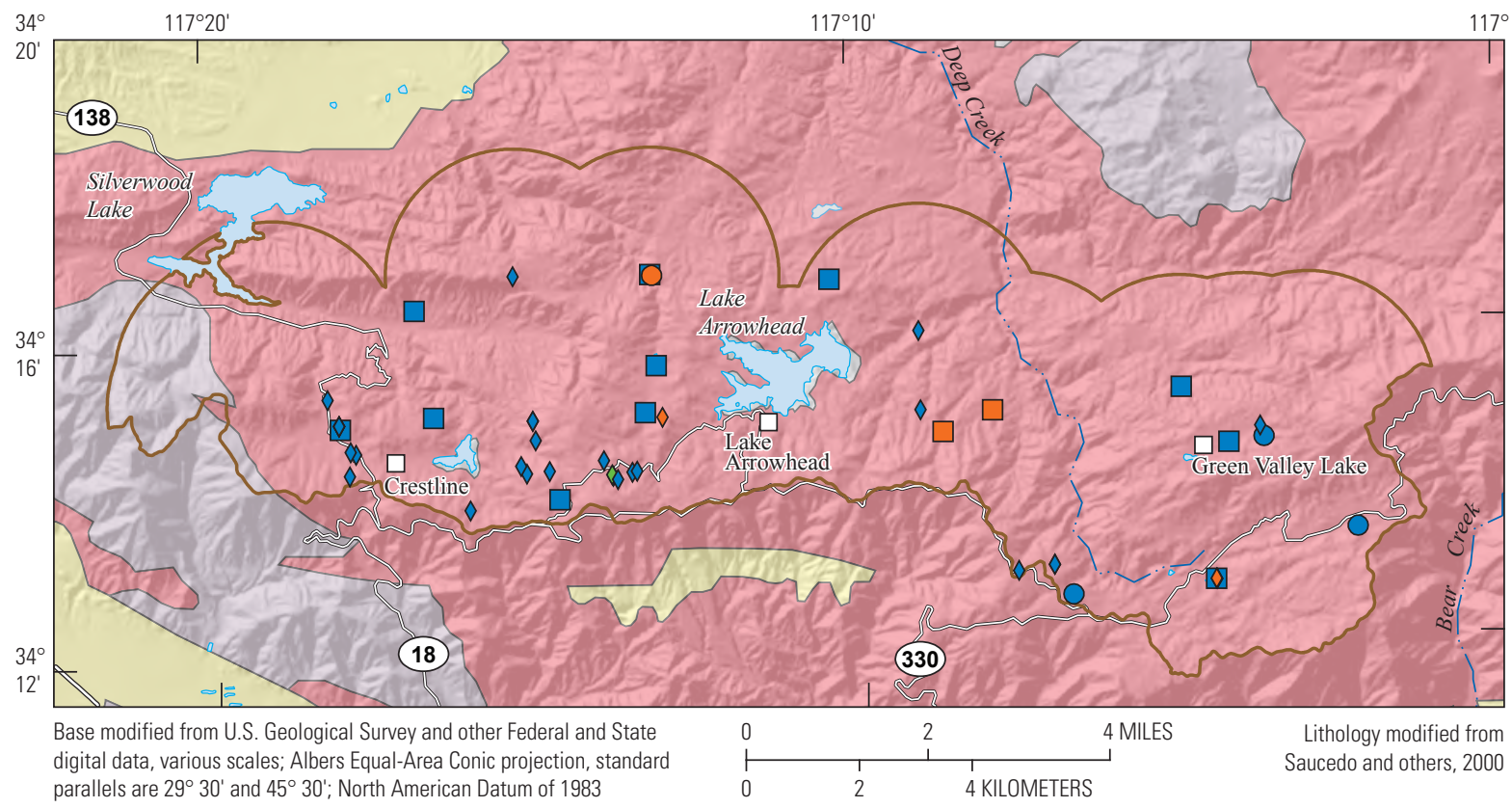

\section{EXPLANATION}

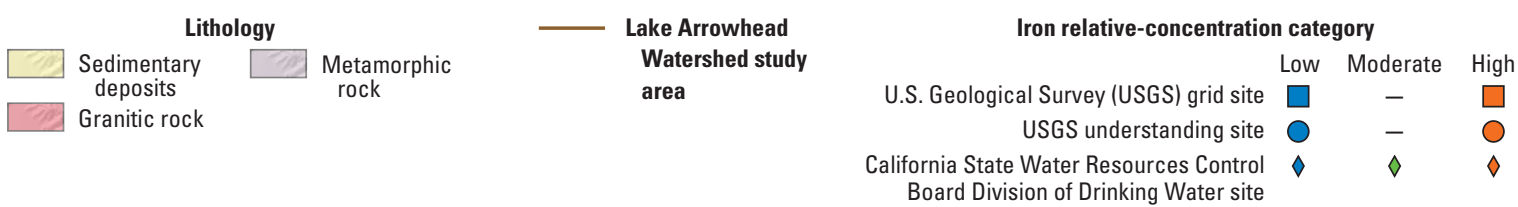

Figure 18. Geologic features and relative concentrations of iron in groundwater samples from U.S. Geological Survey (USGS) grid and understanding sites (2010) and California Division of Drinking Water (SWRCB-DDW) sites (April 1, 2007-April 1, 2010) in two study areas of California Groundwater Ambient Monitoring and Assessment (GAMA) Priority Basin Project: $A$, Bear Valley, and B, Lake Arrowhead Watershed. 
$\boldsymbol{A}$

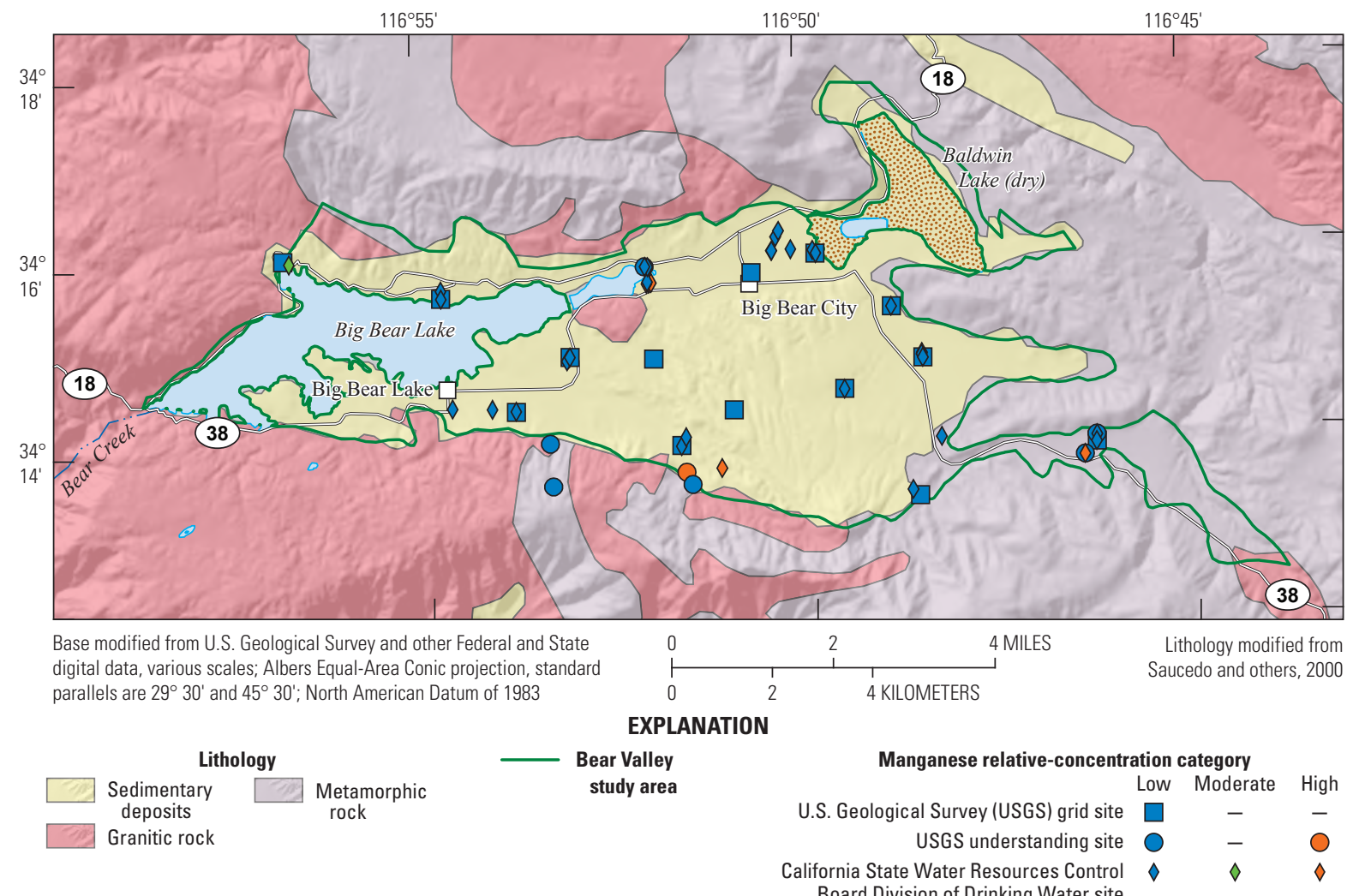

B

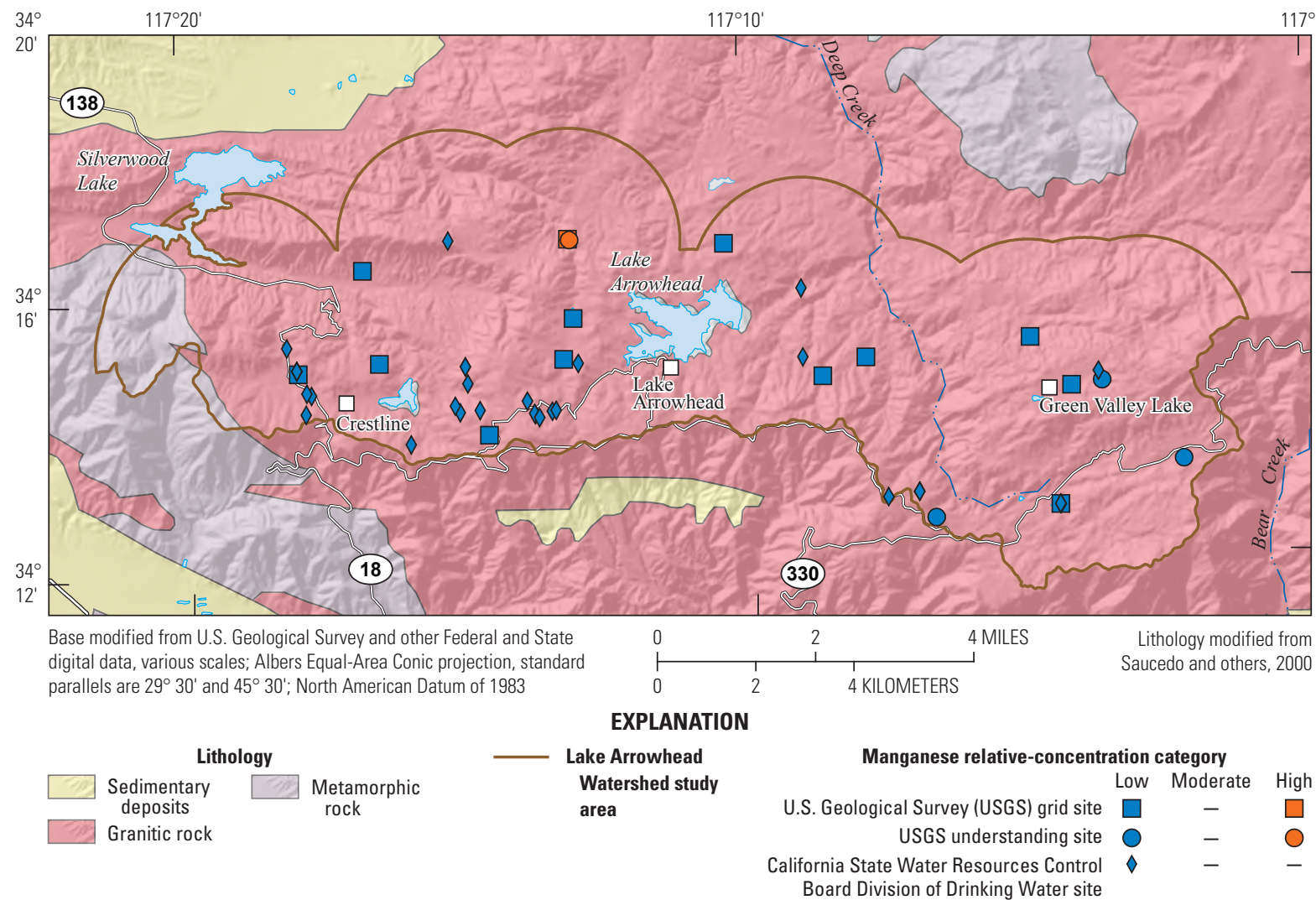

Figure 19. Geologic features and relative concentrations of manganese in groundwater samples from U.S. Geological Survey (USGS) grid and understanding sites (2010) and California Division of Drinking Water (SWRCB-DDW) sites (April 1, 2007-April 1, 2010) in two study areas of the, California Groundwater Ambient Monitoring and Assessment (GAMA) Priority Basin Project: $A$, Bear Valley, and $B$, Lake Arrowhead Watershed. 


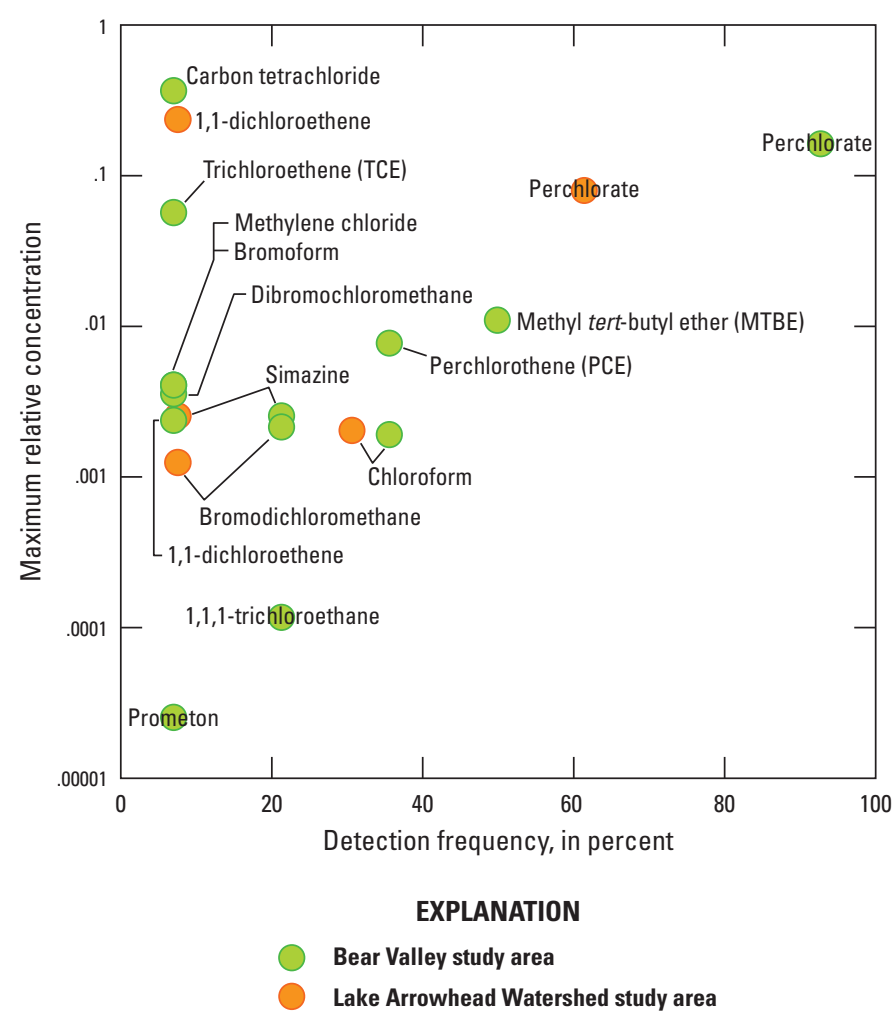

Figure 20. Frequency of detection and maximum relative concentration of organic and special-interest constituents in groundwater samples from U.S. Geological Survey (USGS) grid sites, Bear Valley and Lake Arrowhead Watershed study areas, 2010, California Groundwater Ambient Monitoring and Assessment (GAMA) Priority Basin Project.

\section{Trihalomethanes}

Water for drinking water and other household uses in domestic and public (municipal and community) systems can be disinfected by using chlorine in a variety of chemical forms (such as sodium hypochlorite, or bleach; hypochlorous acid; chlorine gas; chloramines; or chlorine dioxide). As a side effect to disinfecting the water, the chlorine can react with natural organic matter to produce THMs and other chlorinated or brominated disinfection byproducts. Trihalomethanes have been widely detected in national, regional, and local studies of VOCs in ground, surface, source, and drinking waters (Ivahnenko and Barbash, 2004). In the USGS NAWQA Program, THMs were the most frequently detected VOCs in groundwater nationwide (Zogorski and others, 2006). The THMs analyzed in this study were chloroform, bromodichloromethane, dibromochloromethane, and bromoform, all of which were detected in samples from at least one USGS grid site. The MCL-US for THMs applies to the sum of the four species; therefore, the sum of all THM species was used for the status and understanding assessments.

Trihalomethanes were detected at low RCs in samples from approximately 40 percent of the USGS grid sites in both study areas (fig. 21), and Wilcoxon rank-sum test comparisons of THM detection frequencies and concentrations found no significant difference between the two study areas (table 5). Low RCs of THMs were detected in 43 percent and 39 percent of the primary aquifer systems of the BV and LAW study areas, respectively (figs. $21 A, B$ ). In the SWRCB-DDW waterquality database, THMs detected at high RCs before April 1, 2007, were reported, but THMs were not measured at high RCs during this study (table 4).

\section{Understanding Assessment for Trihalomethanes}

Nationally, the presence of THMs in groundwater samples commonly is positively correlated to the percentage of urban land use and density of septic systems near the site (Zogorski and others, 2006). Potential urban sources of THMs include recharge from landscape irrigation with disinfected water, leakage from public-supply water distribution systems, and industrial and commercial usage of chlorinated disinfectants and reagents (Ivahnenko and Barbash, 2004). Septic systems can be a source of THMs to groundwater because they recharge water that has been used for domestic purposes, which could have been disinfected for household use, or could contain residues of bleach and other cleaning products containing chlorine that have been used in the house. Well-head chlorination systems are another potential source of THMs. Generally these systems are within a few feet of the well head. In most of the USGS grid sites, they were downstream of the point where the samples were collected, but some backflow of chlorinated water is possible. The presence of THMs could also have been a consequence of intentional introduction of chlorine solutions into wells. Shock chlorination (often carried out by pouring bleach down a well) is a recommended procedure for treating bacterial contamination and odor problems in domestic drinking-water supply sites (U.S. Centers for Disease Control and Prevention and U.S. Department of Housing and Urban Development, 2006) and could result in the formation of a reservoir of chlorinated water in the well bore and surrounding aquifer material. Smaller water systems, such as those for schools, campgrounds, restaurants, small community associations, and domestic site owners, could be more likely to maintain their sites following guidelines for domestic sites than are large public-supply water systems, such as municipalities.

The distribution of detections of THMs in samples from the BEAR study unit showed no simple relation to likely explanatory factors, indicating a complex combination of sources. Concentrations of THMs were not significantly correlated to percentage of urban land use, septic-tank density, or groundwater age, either in the study unit as a whole or in either study area separately. The only statistically significant relation that could have explanatory value was between the frequency of THM detections and site type. The detection frequency of THMs in samples from well sites (42 percent) was greater (contingency-table test, $p=0.036$ ) than the detection frequency of THMs in samples from spring sites (8.3 percent). 
$\boldsymbol{A}$

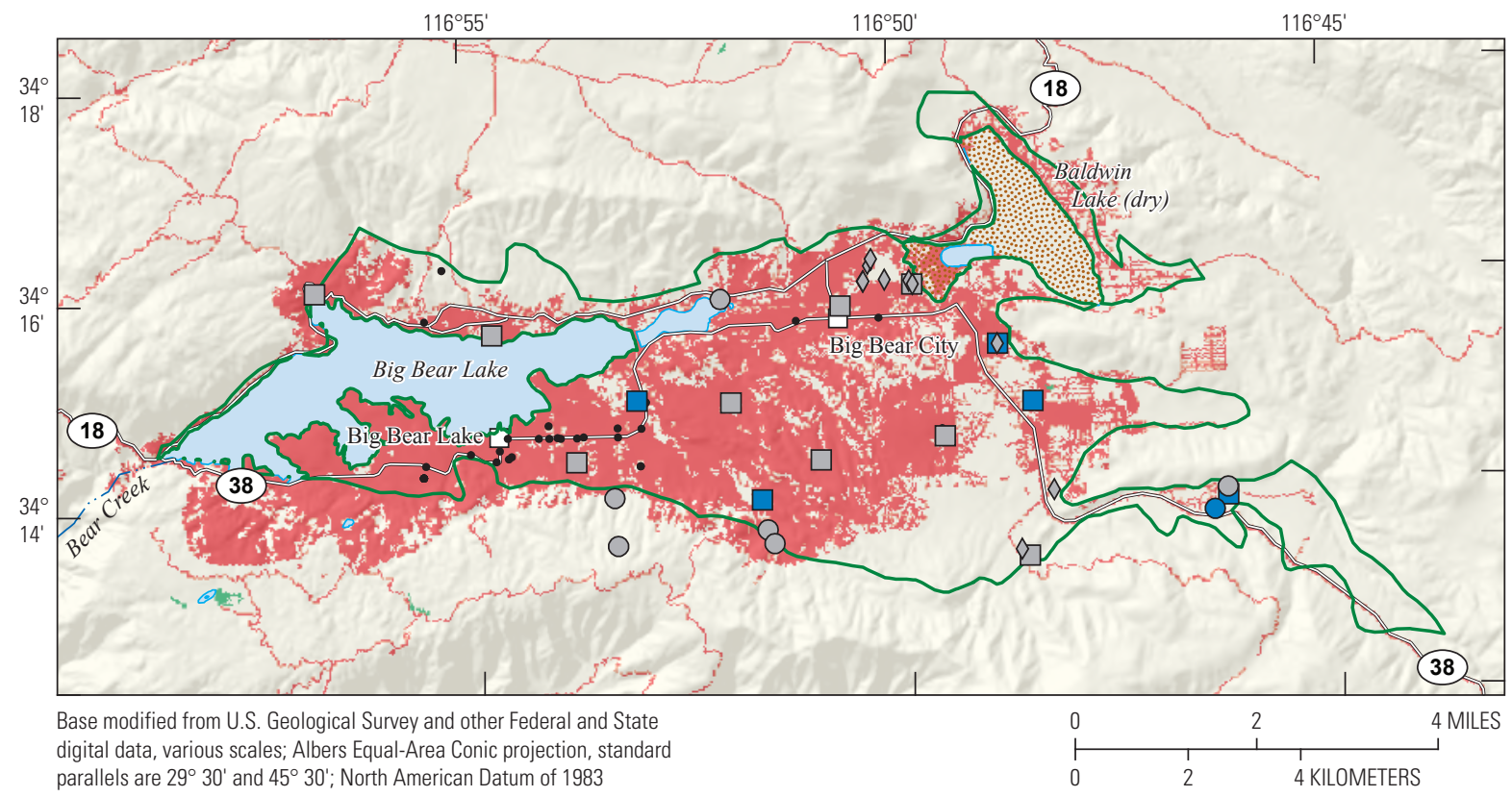

EXPLANATION

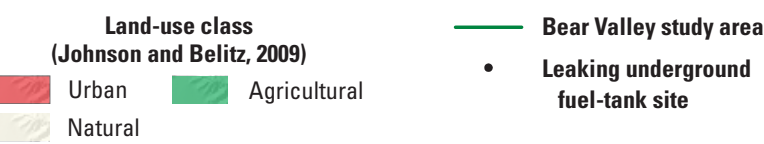

$\begin{aligned} \text { Trihalomethane (THM) relative-concentration category } & \text { Not detected Low } \\ \text { U.S. Geological Survey (USGS) grid site } & \square\end{aligned}$

$\boldsymbol{B}$

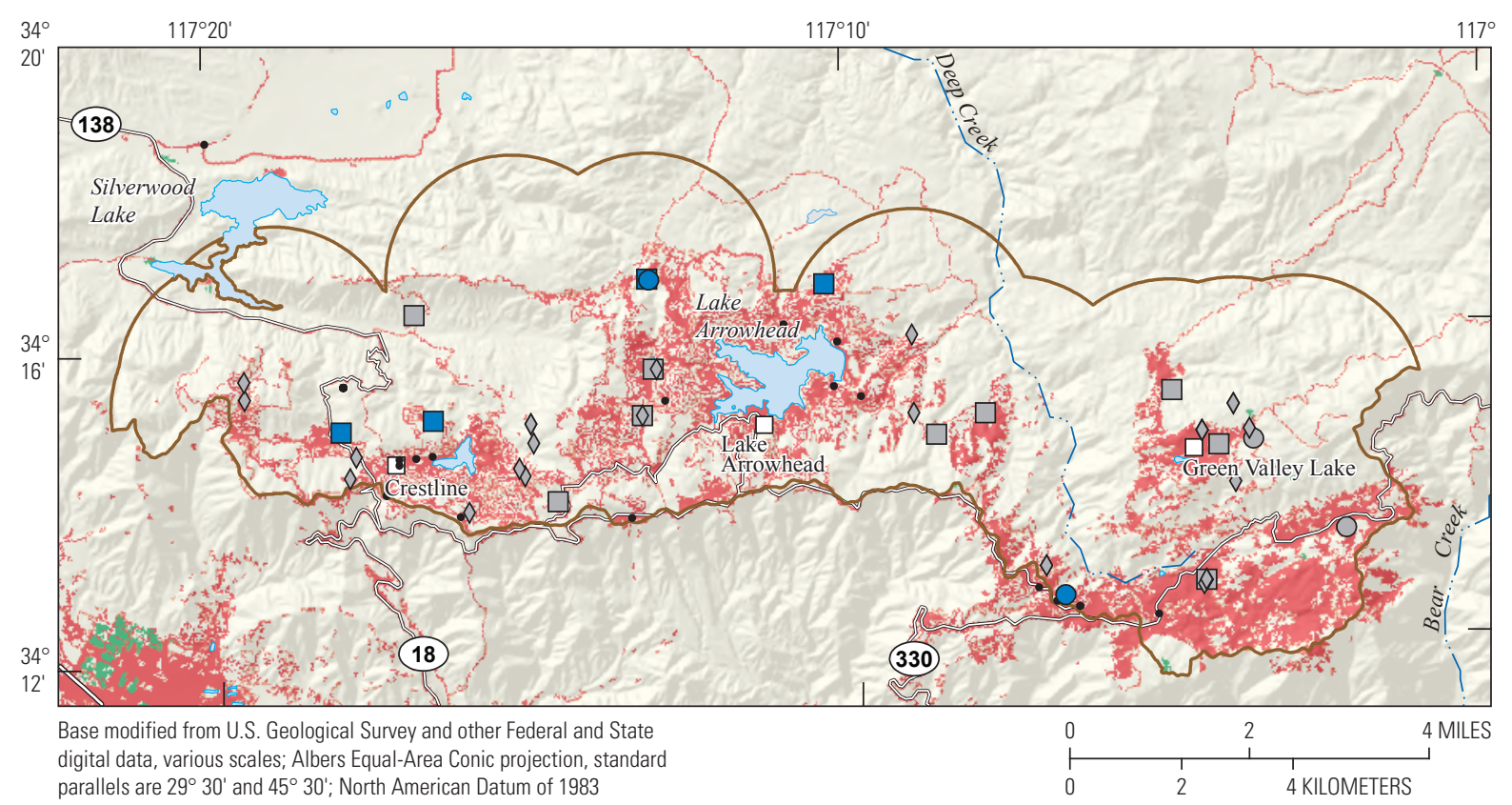

EXPLANATION

\begin{tabular}{|lll}
\begin{tabular}{|l} 
Land-use class \\
(Johnson and Belitz, 2009)
\end{tabular} & $\begin{array}{c}\text { Lake Arrowhead Watershed } \\
\text { study area }\end{array}$ \\
\hline Urban & Agricultural & Leaking underground \\
futural & & fuel-tank site \\
\hline
\end{tabular}

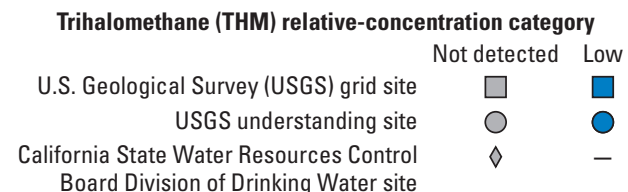

Figure 21. The 2001 land use, location of leaking (or formerly leaking) underground fuel tanks, and relative concentrations of trihalomethanes (THMs) in groundwater samples from U.S. Geological Survey (USGS) grid and understanding sites (2010) and from California Division of Drinking Water (SWRCB-DDW) sites (April 1, 2007-April 1, 2010) for two study areas of the California Groundwater Ambient Monitoring and Assessment (GAMA) Priority Basin Project: $A$, Bear Valley and $B$, Lake Arrowhead Watershed. (Land-use classes are aggregated from those used in the source database, LaMotte, 2008). 
In the BV study area, THMs were detected in samples from five USGS grid sites (fig. 21A); all of the sites were wells, and four of the five sites were surrounded by greater than 50 percent urban land use (fig. 22). All five of these USGS grid sites were considered to be part of large publicsupply water systems, and three of these five sites had well-head chlorination equipment within a few feet from the sampling point. In addition to the USGS grid detections, THMs were detected in a samples from one USGS

understanding well. This well was also part of a large publicsupply water system, in an urban setting, that used well-head chlorination practices.

In the LAW study area, THMs were detected in samples from four USGS grid sites (fig. 21B), of which, three were wells and one was an unchlorinated spring. All four of the sites were surrounded by natural land use (fig. 22). The three wells had no well-head chlorination systems present, but were considered to be part of small water systems, so they could have been treated by shock chlorination practices. In addition, THMs were detected in samples from two USGS understanding sites that had characteristics similar to the USGS grid sites in the LAW study area. The USGS understanding sites were wells surrounded by natural land use that were part of small water systems and had no well-head chlorination.

\section{Gasoline Components}

Gasoline components include gasoline oxygenates and hydrocarbons. Gasoline oxygenates are compounds that contain oxygen and are added to gasoline to increase the efficiency of combustion in order to meet the requirements of the 1990 Clean Air Act Amendments. Gasoline hydrocarbons are compounds in gasoline and other finished fuel products, such as motor oil (Zogorski and others, 2006). The gasoline oxygenate MTBE (methyl tert-butyl ether) was the only gasoline component detected in sampled groundwater of the BEAR study unit (fig. 9). These MTBE detections were limited to samples collected in the BV study area, where it was measured at low RCs in 50 percent of the primary aquifer system and not detected in 50 percent (fig. 23A).

\section{Understanding Assessment for Methyl Tert-Butyl Ether (MTBE)}

In California, MTBE was used as the primary gasoline oxygenator until a phased reduction process was initiated in 2004 because of numerous concerns about MTBE from many point and non-point sources degrading groundwater quality (California Air Resources Board, 2003; Rausser and others, 2004). Point sources of MTBE include LUFTs, leaks from bulk gasoline stations or transport pipelines, and storage-tank spills (Rausser and others, 2004; Zogorski and others, 2006). Non-point sources of MTBE include atmospheric deposition from incomplete combustion and exhaust from automobile, snow machine, and watercraft engines, evaporative losses from storage tanks or pipelines, urban stormwater runoff, used motor oil, and other non-point sources (Zogorski and others, 2006). Previous studies by the USGS on the large-scale sources of MTBE in groundwater have specifically associated MTBE detections with high population density, urban land use, LUFT density, historical use, and atmospheric deposition

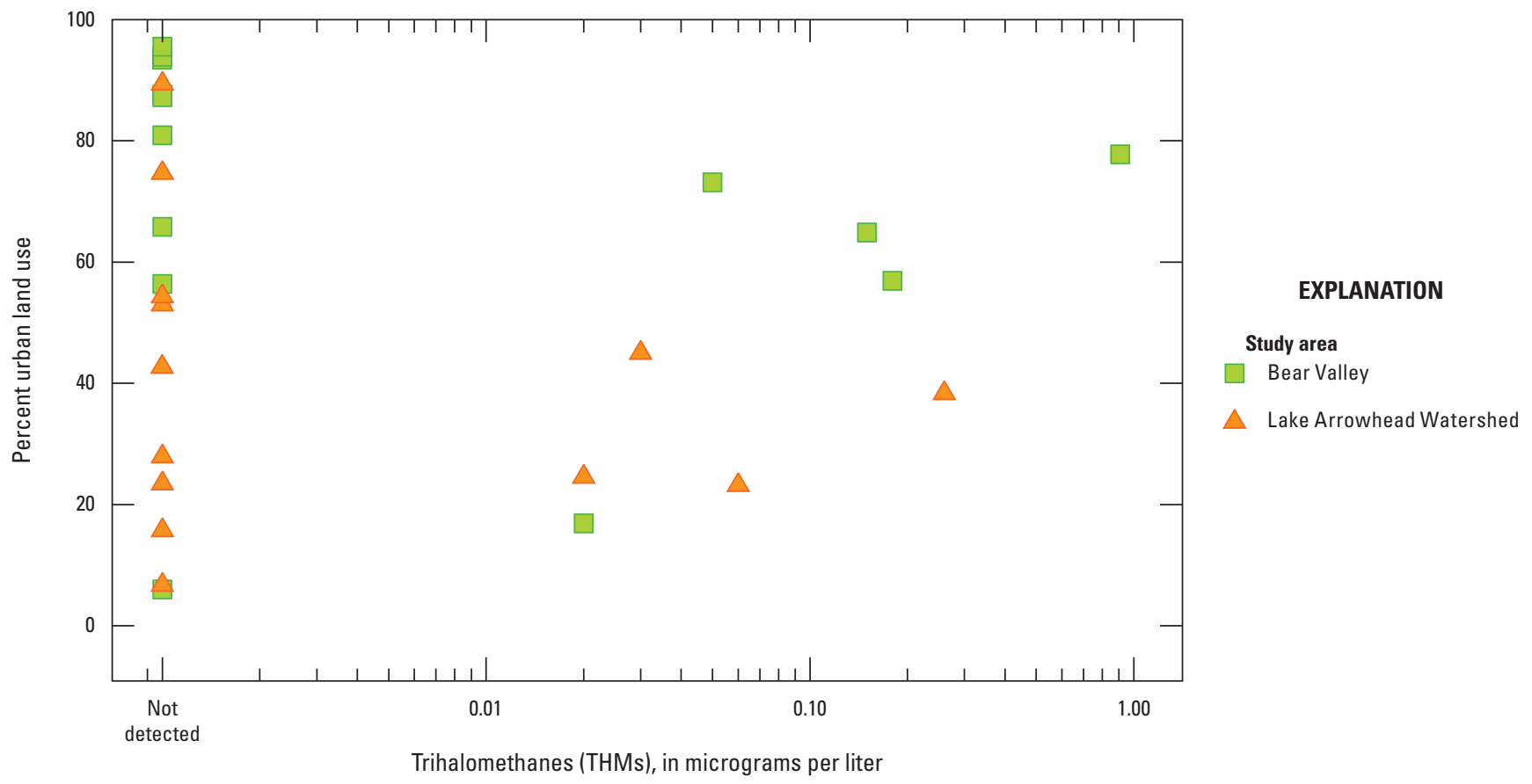

Figure 22. Relation of 2001 urban land use to trihalomethane (THM) concentration in samples from U.S. Geological Survey (USGS) grid sites, by study area, Bear Valley and Lake Arrowhead Watershed study unit, 2010, California Groundwater Ambient Monitoring and Assessment (GAMA) Priority Basin Project. 
$\boldsymbol{A}$

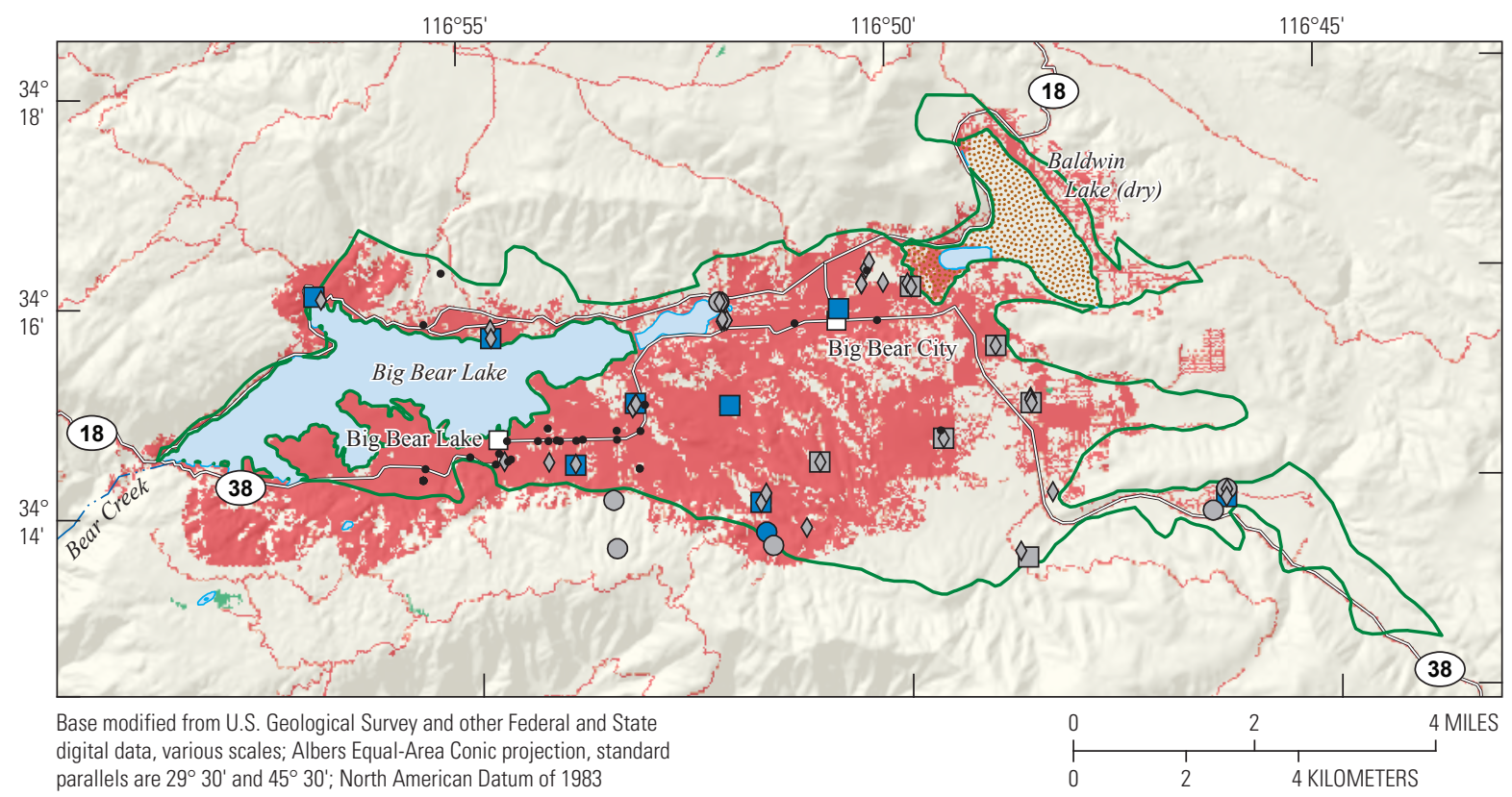

EXPLANATION

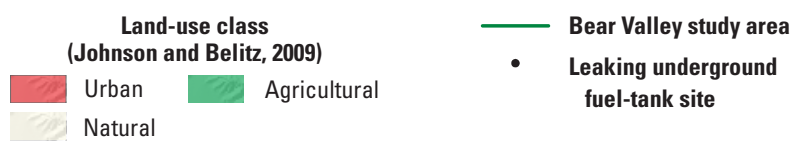

Methyl tert-butyl ether (MTBE) relative-concentration category

Not detected Low USGS understanding site

California State Water Resources Control Board Division of Drinking Water site

$\boldsymbol{B}$

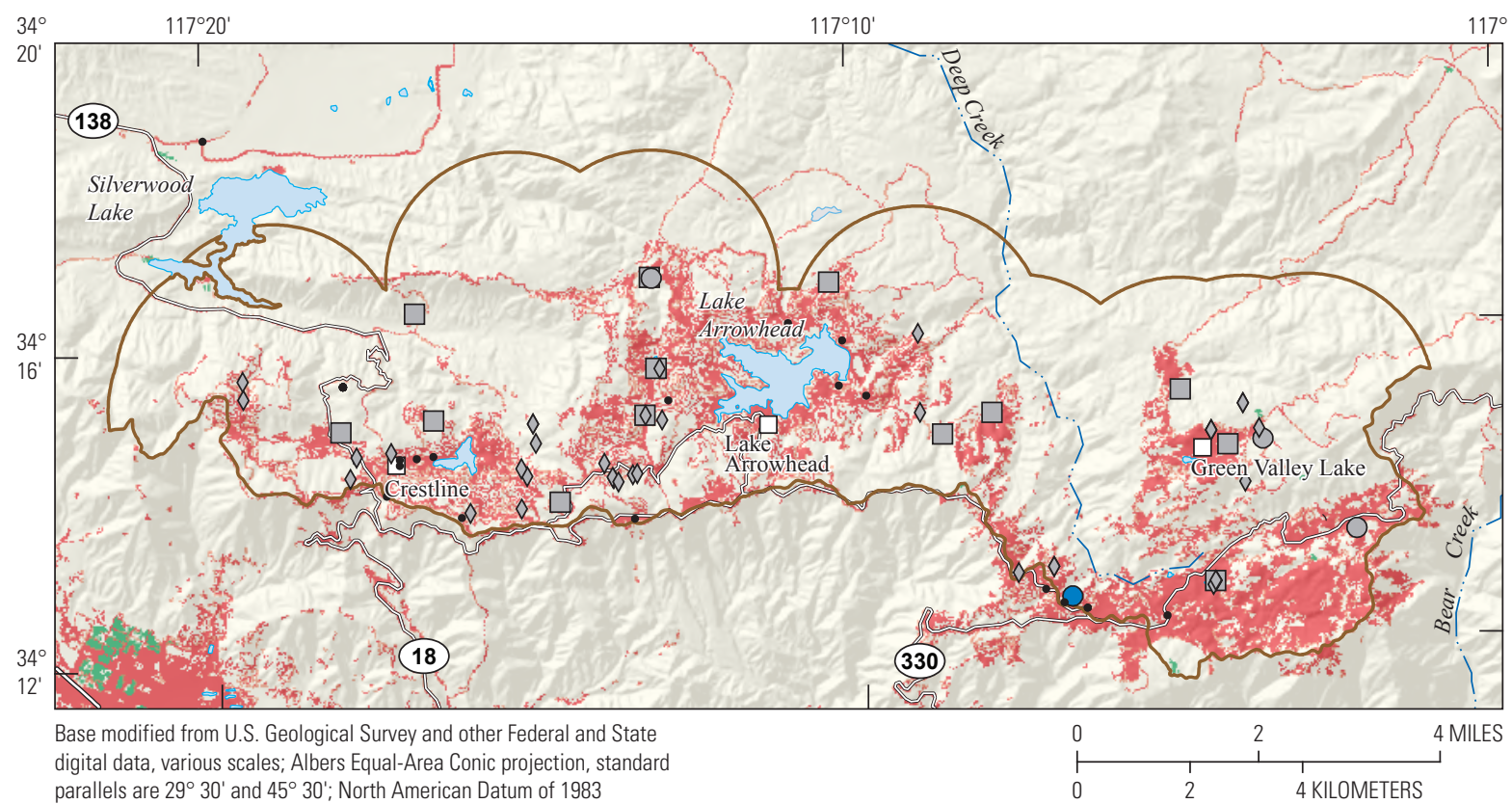

EXPLANATION
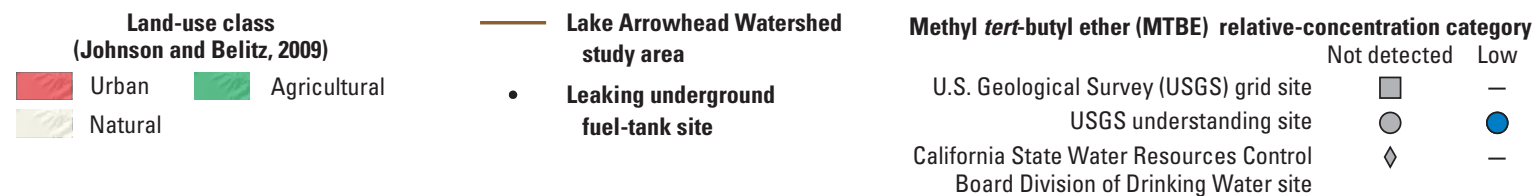

Figure 23. Land use, leaking (or formerly leaking) underground fuel-tanks (LUFTs), and relative concentrations of MTBE (methyl tertbutyl ether) in samples from U.S. Geological Survey (USGS) grid and understanding sites (2010) and California Division of Drinking Water (SWRCB-DDW) sites (April 1, 2007-April 1, 2010) in two study areas of the California Groundwater Ambient Monitoring and Assessment (GAMA) Priority Basin Project: $A$, Bear Valley and $B$, Lake Arrowhead Watershed. 
(Zogorski and others, 2001, 2006; Moran and others, 2005: Fram and Belitz, 2014).

The physical and chemical properties of MTBE have allowed it to reach groundwater and to travel faster and farther in the environment than other gasoline compounds. MTBE is relatively soluble in water, has a low affinity for soil adsorption, tends to partition from air into water, undergoes vapor-phase transport in the unsaturated zone, and is slow to biodegrade (Zogorski and others, 2006). As a result, once MTBE has been introduced to the environment, it becomes a pervasive and persistent contaminate in groundwater that degrades only slightly over years or decades (Ayotte and others, 2004; Zogorski and others, 2006).

Fram and Belitz (2014) developed a procedure that used Henry's Law constant to quantify the partitioning of MTBE between urban air and precipitation falling during the period when it was used as a gasoline oxygenate (1992-2003), and this procedure was applied to the BEAR study unit. The cities in the BEAR study unit were not monitored by California Air Resources Board during the period when MTBE was used, so the maximum annual average MTBE concentrations in the air of the cities closest to the BEAR study unit were used in the Henry's Law constant calculations. The maximum annual average MTBE concentration was 5.3 parts per billion by volume (PPBv; California Air Resources Board, 2004), corresponding to raindrops containing approximately $1.1 \mu \mathrm{g} / \mathrm{L}$ of MTBE. The maximum concentration of MTBE measured from USGS grid sites was $0.14 \mu \mathrm{g} / \mathrm{L}$ (Mathany and Belitz, 2013). In samples from the understanding sites, MTBE was detected at a concentration of $0.64 \mu \mathrm{g} / \mathrm{L}$ for one site in the BV study area at a concentration of $0.24 \mu \mathrm{g} / \mathrm{L}$ for one site in the LAW study area.

If atmospheric deposition, from regional input, was the major non-point source for MTBE, then one would expect similar detection frequencies of MTBE for the USGS grid sites in the BV and the LAW study areas. In this study, Wilcoxon rank-sum tests indicated MTBE was detected more frequently and at greater concentrations in samples from USGS grid sites in the BV study area than in those from the LAW study area (table 5). MTBE was detected in samples from 50 percent of the USGS grid sites in the BV study area (fig. 23A), but was not detected in samples from the UGSG grid sites in the LAW study area (fig. 23B).

The distribution and frequency of MTBE detections in groundwater from the BEAR study unit was most likely due to a combination of factors including land use, site type, and groundwater age. Land use in the BV study area is significantly more urban than the land use in the LAW study area, so it is reasonable to assume that MTBE used historically has accumulated in the BV study area. Given the persistence of MTBE in groundwater, the site types and groundwater age are likely to be related to where MTBE is detected in the BEAR study unit. For instance, MTBE was only detected in samples from USGS grid sites that were wells. Wells with older groundwater (median tritium concentration was $0.6 \mathrm{TU}$ ) are characteristic of the BV study area, so it is possible that MTBE originating from urban activities, regional and local atmospheric deposition, and other point and non-point sources is still interacting with the groundwater in the primary aquifer system (fig. 24).

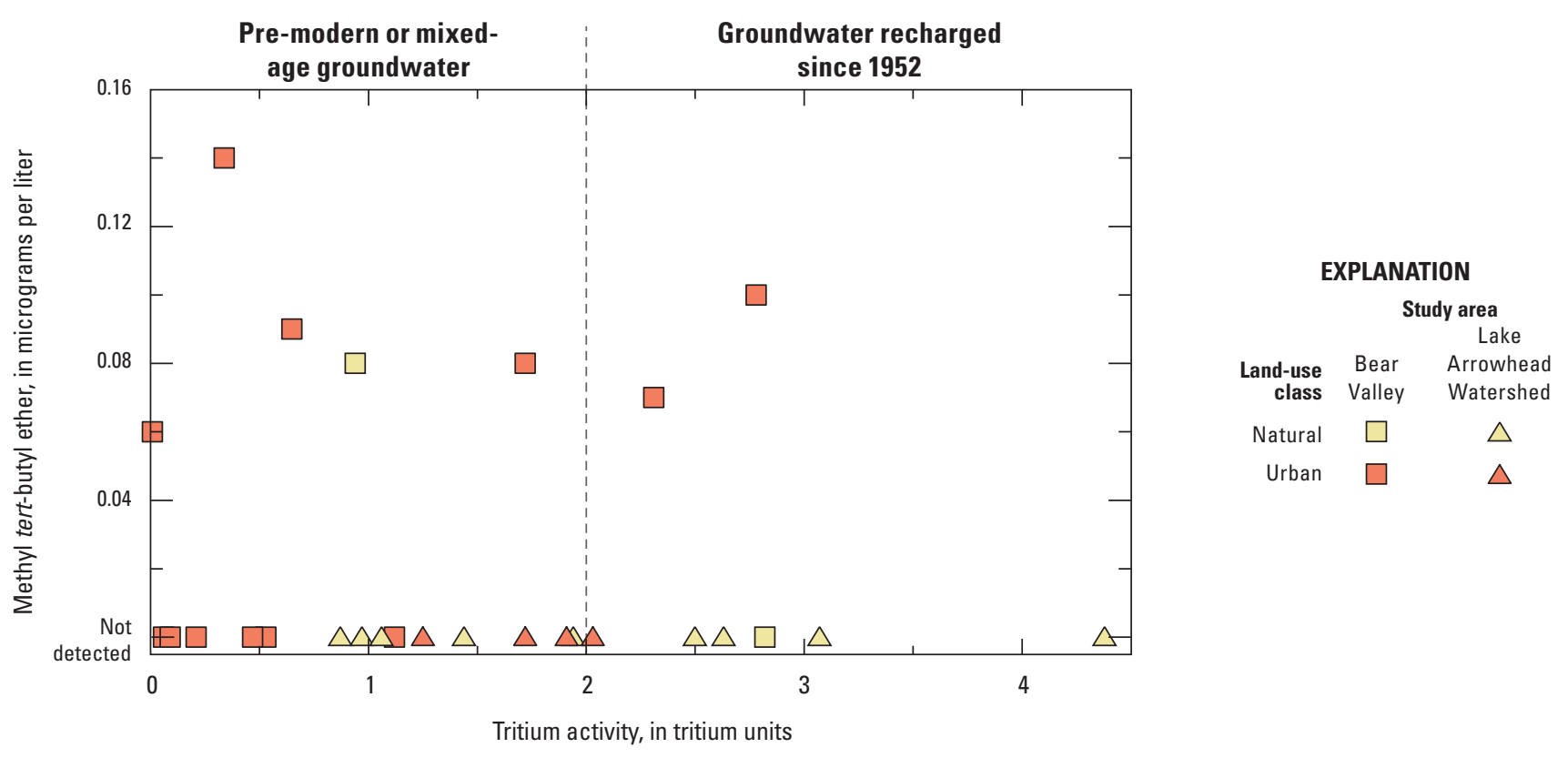

Figure 24. Relation of MTBE (methyl tert-butyl ether) concentration to tritium activity (by study area and by dominant 2001 land use) in samples from U.S. Geological Survey (USGS) grid sites, Bear Valley and Lake Arrowhead Watershed study unit, 2010, California Groundwater Ambient Monitoring and Assessment (GAMA) Priority Basin Project. 


\section{Solvents}

Solvents are used for a variety of industrial, commercial, and domestic purposes (Zogorski and others, 2006). Solvents have been associated with acute and chronic human-health problems, so the EPA has set the MCL-US for some solvents in drinking water at very low concentrations (Moran and others, 2007). Many of the factors associated with the distribution of individual solvents were similar (Zogorski and others, 2006); therefore, solvents were considered as a class rather than as individual constituents for the status and understanding assessment. Solvents were detected in samples from the BV study area at high RCs in 1.0 percent of the primary aquifer system and at moderate RCs in 3.6 percent (table 7). Solvents were detected at high RCs for two SWRCB-DDW sites and at a moderate RC for one SWRCBDDW site in the BV study area (fig. 25A). Solvents were detected at a moderate RC for one USGS grid site in the LAW study area (fig. $25 B$; table 7).

\section{Understanding Assessment for Solvents}

Historically, solvents have had a wide variety of applications, including dry cleaning, degreasing and cleaning of metal parts, paint stripping, fire extinguishers, adhesives, lubricants, and silicones (Zogorski and others, 2006; Petrisor and Wells, 2008). Total solvent concentrations were the sum of the RCs of the six solvents detected (tetrochloroethene, or PCE; 1,1,1-trichloroethane, or 1,1,1-TCA; 1,1-dichloroethene, or 1,1-DCE; methylene chloride; carbon tetrachloride; and trichloroethene, or TCE). The largest contributions to solvents detections in the BEAR study unit were from PCE, 1,1,1-TCA, 1,1-DCE, and carbon tetrachloride. The solvent PCE, used in dry cleaning, was the second most frequently detected VOC in aquifers nationally, based on assessments by the USGS NAWQA program (Zogorski and others, 2006), and in California, based on an analysis of SWRCB-DDW data (Williams and others, 2002). The solvent 1,1,1-TCA, used in textile processing, was the seventh most frequently detected VOC in aquifers assessed by the USGS NAWQA program (Zogorski and others, 2006). The solvent 1,1-DCE is commonly used to make polyvinyl chloride (PVC) pipes (U.S. Environmental Protection Agency, 2015b). Carbon tetrachloride is commonly used in dry cleaning operations and in fire extinguishers (Zogorski and others, 2006).

The presence of solvents in groundwater has been associated with increased urban land use, population density, and septic systems (Moran and others, 2007). Much like MTBE, once solvents are released in an urban environment, widespread groundwater contamination can result because of a combination of physical and chemical properties. Solvents have high solubilities and densities greater than water, which means that solvents released to land surfaces can move relatively quickly in solution and enter the aquifer system. Solvents also biodegrade slowly and can persist in aquifer systems for long periods (Zogorski and others, 2006; Moran and others, 2007; Petrisor and Wells, 2008).

Solvents were detected more frequently and at greater concentrations in samples from the BV study area than from the LAW study area (table 5). Like MTBE, solvents were detected most frequently in samples from wells with groundwater classified as either mixed or pre-modern age (seven out of nine wells; median tritium concentration of 0.9 TU). Additionally, eight out of nine wells where solvents were detected were surrounded by greater than 50 percent urban land use. Solvents and MTBE were detected together in samples from five USGS grid sites in the BV study area (Mathany and Belitz, 2013). Given the chemical and physical similarities in solvents and MTBE, these results indicated that solvent detections were likely due to its historical and continuing use in urban settings leading to accumulation in the primary aquifer system over time.

\section{Pesticides and Pesticide Degradates}

Low RCs of pesticide and pesticide degradates were found in 21 percent and 7.7 percent of the primary aquifer systems in the BV and LAW study areas, respectively (table 6). The herbicides simazine and prometon were the only pesticides or pesticide degradates detected in the BEAR study unit (tables 2, 3; fig. 9).

Simazine has been among the most commonly detected herbicides in groundwater in major aquifers across the United States (Gilliom and others, 2006). Simazine also has been the most frequently detected triazine herbicide in groundwater in California (Troiano and others, 2001), where its primary uses are for weed control in orchards, vineyards, and rights-of-way (Kegley and others, 2014). Simazine has many characteristics that allow it to persist in the environment and, make it likely to contaminate groundwater; it is moderately soluble, does not adsorb strongly to soil particles, and has a lengthy soil half-life (Extension Toxicology Network, 1993; Gunasekara, 2004; Navarro and others, 2004). Previous studies by the USGS and others on simazine in groundwater have correlated its detection to oxic conditions, agricultural and urban land use, shallow well depth, and modern-age groundwater (Dubrovsky and others, 1998; Barbash and others, 1999; U.S. Geological Survey, 1999; Gilliom, 2007; Paul and others, 2007; Kulongoski and others, 2010; Parsons and others, 2014). 


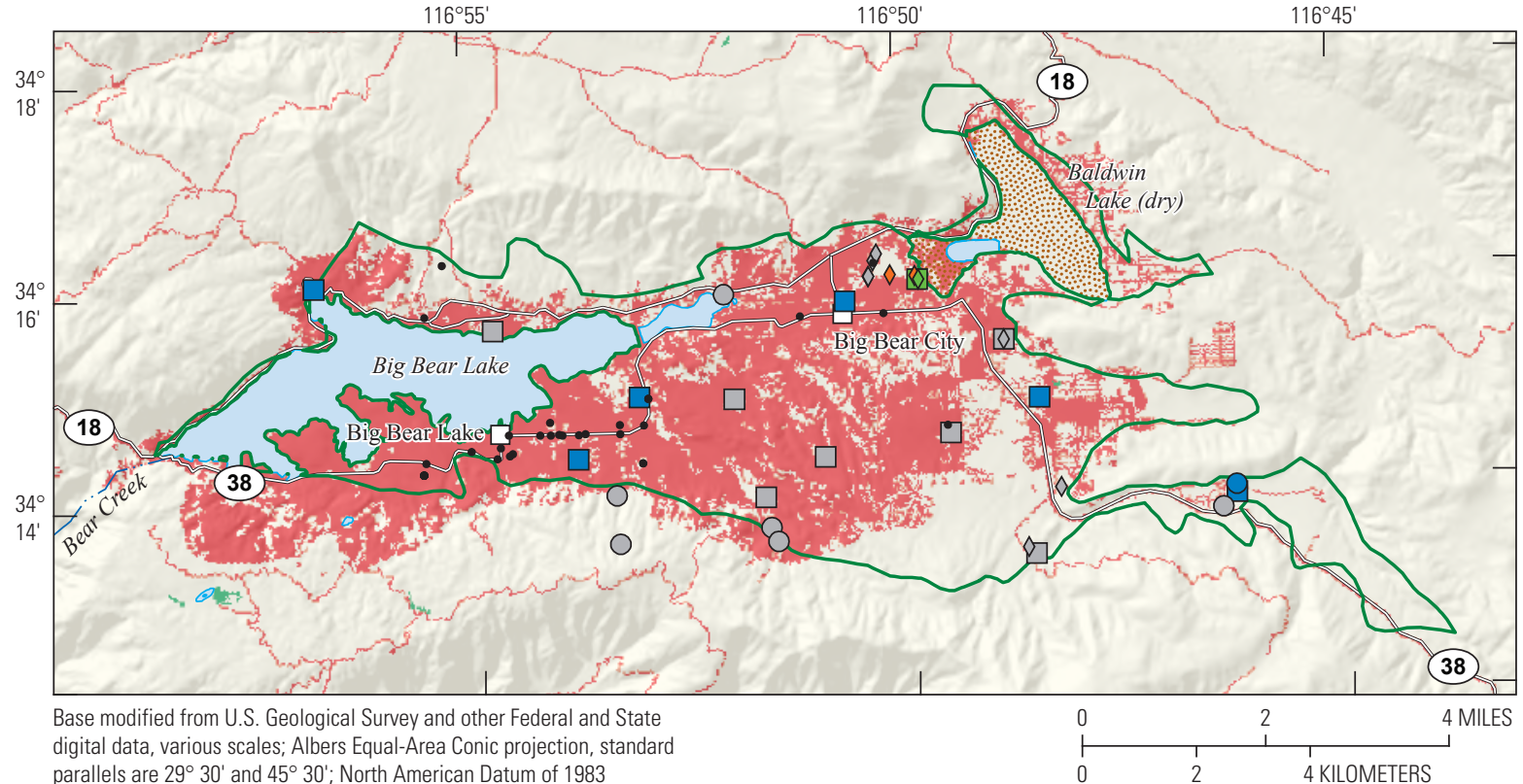

parallels are $29^{\circ} 30^{\prime}$ and $45^{\circ} 30^{\prime}$; North American Datum of 1983

EXPLANATION
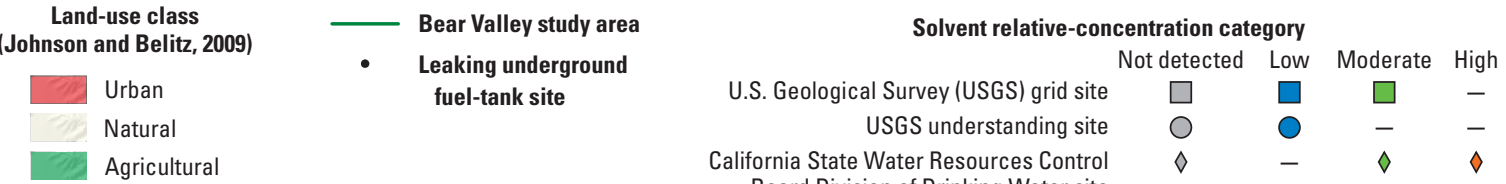

B

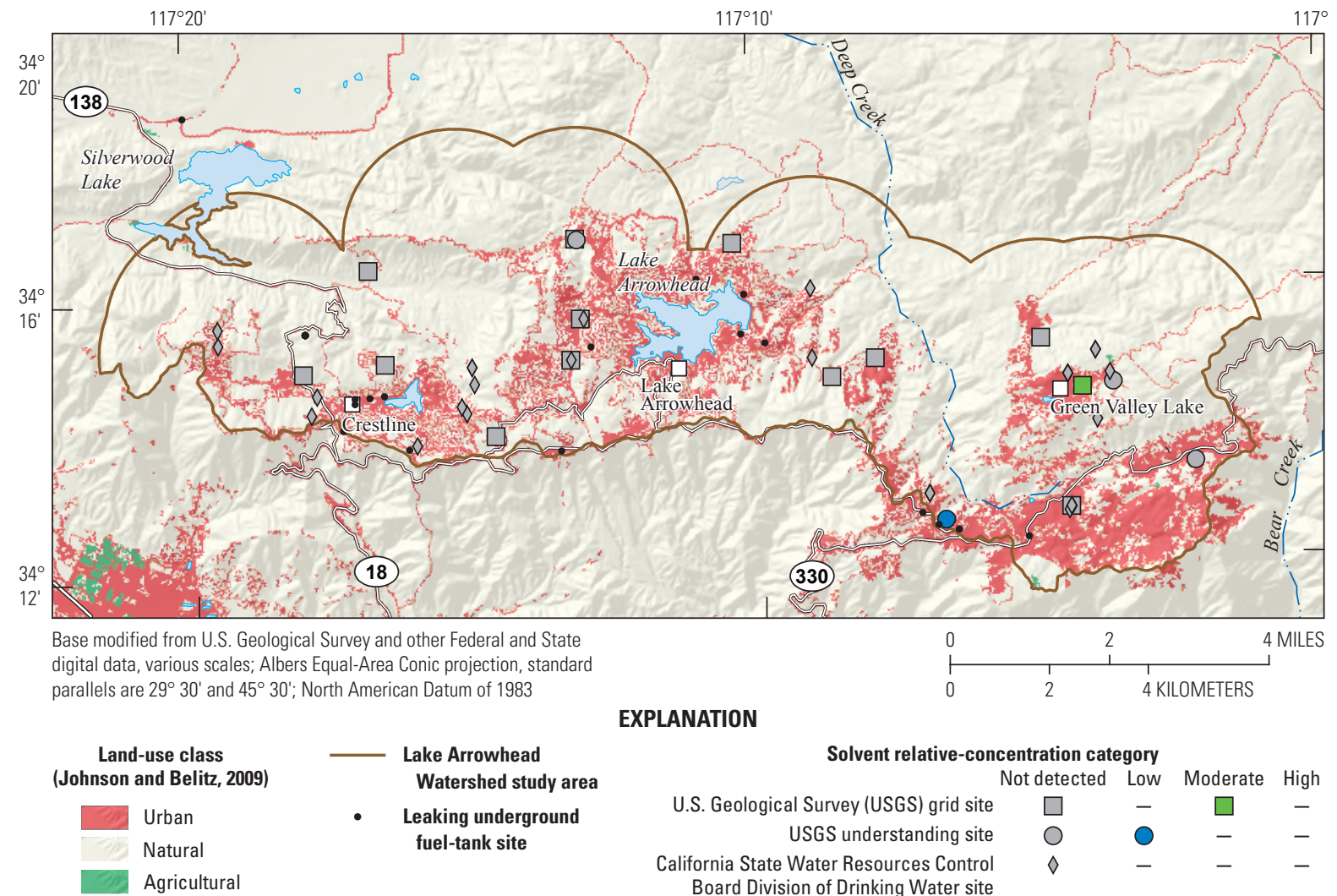

Board Division of Drinking Water site

$117^{\circ} 10^{\prime}$

$117^{\circ}$

EXPLANATION

\begin{tabular}{rrccc}
\multicolumn{5}{c}{ Solvent relative-concentration category } \\
& Not detected & Low & Moderate & High \\
U.S. Geological Survey (USGS) grid site & $\square$ & - & $\square$ & - \\
USGS understanding site & $\bigcirc$ & 0 & - & - \\
California State Water Resources Control & $\diamond$ & - & - & -
\end{tabular}

Figure 25. The 2001 land use and relative concentration of solvents in groundwater samples from U.S. Geological Survey (USGS) grid and understanding sites (2010) and California Division of Drinking Water (SWRCB-DDW) sites (April 1, 2007-April 1, 2010) in two study areas of the California Groundwater Ambient Monitoring and Assessment (GAMA) Priority Basin Project: $A$, Bear Valley and $B$, Lake Arrowhead Watershed. 


\section{Understanding Assessment for Simazine}

Simazine was detected at low RCs in samples from nearly 15 percent (4 out of 27) of the USGS grid sites (figs. 26A, $B$ ). Simazine was significantly correlated with MTBE and solvents (Spearman's rho $=0.478$ for MTBE, $p=0.015 ;$ rho $=0.415$ for solvents, $p=0.035$ ). As with MTBE and solvents, simazine detections were likely related to its persistence in the environment, site type, historical and continuing use in an urban setting, and groundwater age. All of the USGS sites where simazine was detected were wells, and all but one of the detections were in samples from the BV study area (figs. 26A, B). As discussed in the understanding assessment for MTBE and solvents, land use is significantly more urban and groundwater is older on average in the BV study area than in the LAW study area. These results indicated that simazine detections were more than likely due to its historical and continuing use in urban settings leading to accumulation in the primary aquifer system over time.

\section{Special-Interest Constituent, Perchlorate}

Potential sources of perchlorate to groundwater can be anthropogenic or natural. Anthropogenic sources are predominantly the use of the ammonium and potassium salts of perchlorate. These salts are deposited in the environment by the production, use, and disposal of solid rocket fuels, explosives, munitions, safety road flares, de-icing road salts, pyrotechnics (fireworks), automobile airbag systems, and many other commodities and commercial processes (Parker and others, 2008; Munster and Hanson, 2009). The non-reactivity of perchlorate and the solubility of the salts lead to a highly mobile contaminant that readily migrates to surface- and groundwater (Parker and others, 2008). Potential agricultural sources include the Chilean nitrate fertilizer applied extensively in the early to mid-1900s (Dasgupta and others, 2005). Irrigation is also considered an agricultural source where it redistributes perchlorate salts that were naturally present in the unsaturated zone to the groundwater (Fram and Belitz, 2011). Perchlorate is formed naturally in the atmosphere, and very low concentrations are found in precipitation (Dasgupta and others, 2005; Parker and others, 2008; Rajagopalan and others, 2009). Perchlorate can exist naturally under a variety of climatic conditions (Dasgupta and others, 2005; Plummer and others, 2006; Fram and Belitz, 2011). Perchlorate is more likely in arid environments, however, such as the arid and semi-arid environments of the southwestern United States (Fram and Belitz, 2011).
Perchlorate was detected more frequently and at greater concentrations in samples from USGS grid sites in the BV study area than in the LAW study area (table 5). Perchlorate was detected in samples from the BV study area at moderate RCs in 3.6 percent of the primary aquifer system and at low RCs in 86 percent (fig. 27A; table 7). Perchlorate was detected in samples from the LAW study area at low RCs in 62 percent of the primary aquifer system (fig. 27B).

\section{Understanding Assessment for Perchlorate}

Fram and Belitz (2011) developed a logistical regression model to predict the probability of detecting perchlorate in groundwater under natural conditions as a function of climate, and this model was applied to the BEAR study unit.

The predicted probability of detecting naturally existing perchlorate at a concentration greater than $0.5 \mu \mathrm{g} / \mathrm{L}$ in the BV study area was 5.9 to 7.6 percent based on the logistical regression model (Fram and Belitz, 2011). The predicted probability of detecting naturally existing perchlorate at concentrations at the method reporting level (MRL) of $0.1 \mu \mathrm{g} / \mathrm{L}$ was 43 to 55 percent. The observed detection frequency of perchlorate for concentrations greater than $0.5 \mu \mathrm{g} / \mathrm{L}$ (7.1 percent) was in the predicted range of detection probabilities, but the observed detection frequency for concentrations at the MRL ( 85 percent) was much greater than the predicted range. These results indicated that anthropogenic sources could have contributed to low levels of perchlorate in the groundwater of this study area. Potential anthropogenic sources in the BV study area include the use of safety road flares, pyrotechnics (fireworks), de-icing road salts, and other non-point sources; there were no manufacturing or agricultural sources in the study area (National Cooperative Highway Research Program, 2005; U.S. Environmental Protection Agency, 2011; Big Bear Chamber of Commerce, 2015).

The predicted probability of detecting naturally existing perchlorate at a concentration greater than $0.5 \mu \mathrm{g} / \mathrm{L}$ in the LAW study area was 4.5 to 6.6 percent, whereas the predicted probability of natural perchlorate concentrations at the MRL was 41 to 48 percent. Perchlorate was not detected at concentrations greater than $0.5 \mu \mathrm{g} / \mathrm{L}$ in samples from the LAW study area, and the observed detection frequency at the MRL was 53 percent - slightly greater than the predicted range for the frequency of detecting naturally present perchlorate. These results indicated that the source of perchlorate was most likely precipitation (rain and snow), with minimal contribution from anthropogenic sources. Analysis of perchlorate isotopes could help to resolve the sources of perchlorate in the BEAR study unit, but that is beyond the scope of this study. 


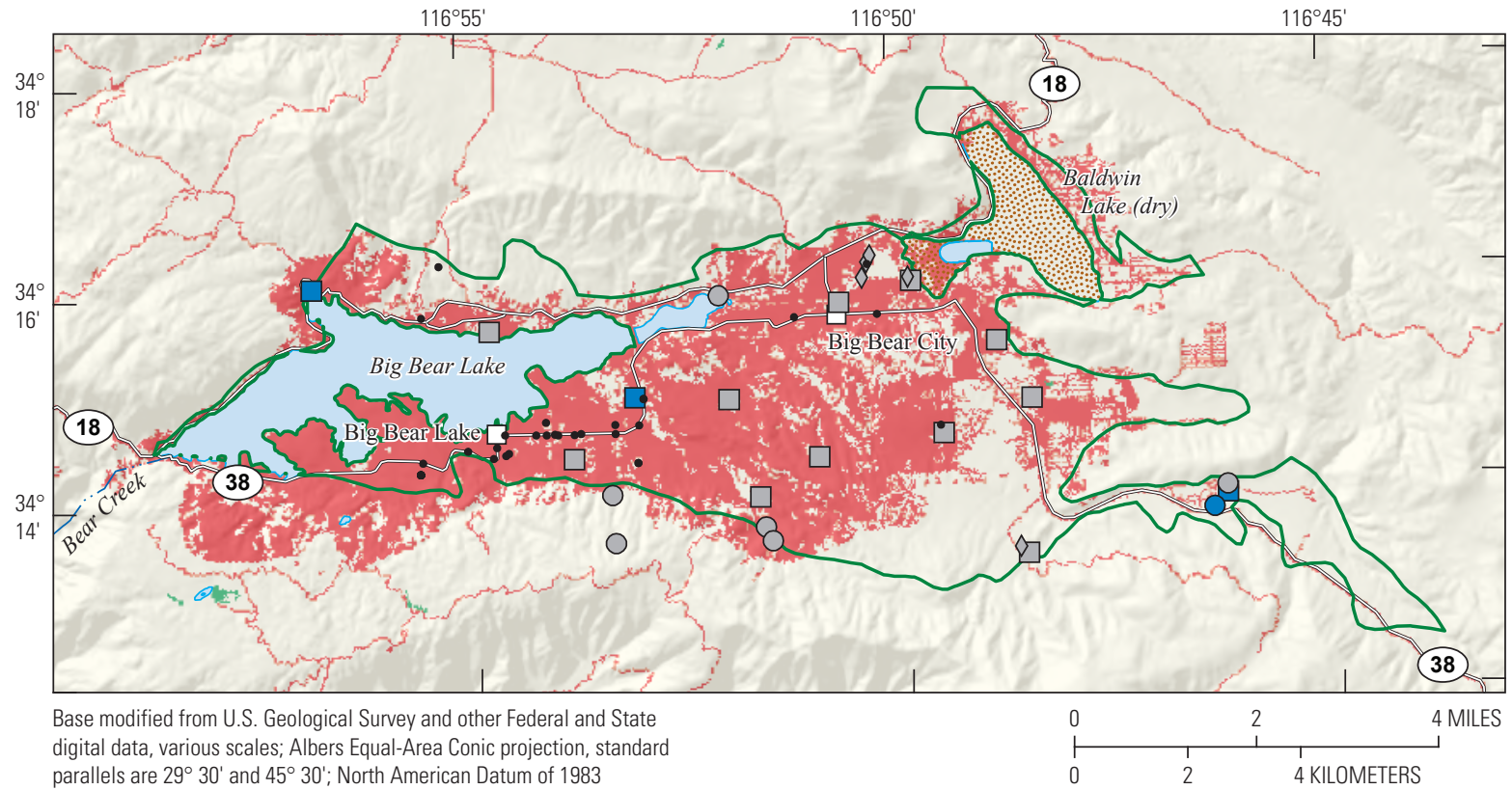

parallels are $29^{\circ} 30^{\prime}$ and $45^{\circ} 30^{\prime}$; North American Datum of 1983

EXPLANATION

\begin{tabular}{|c|c|c|c|}
\hline $\begin{array}{r}\text { Land } \\
\text { (Johnson }\end{array}$ & $\begin{array}{l}\text { d-use class } \\
\text { and Belitz, 2009) }\end{array}$ & $\bullet$ & $\begin{array}{l}\text { Bear Valley study area } \\
\text { Leaking underground }\end{array}$ \\
\hline & Urban & & fuel-tank site \\
\hline & Natural & & \\
\hline & Agricultural & & \\
\hline
\end{tabular}

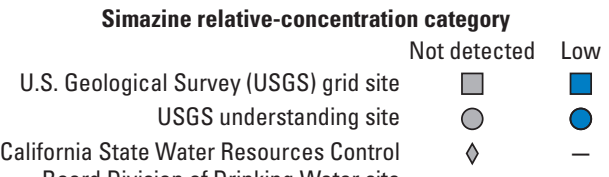

Board Division of Drinking Water site

B

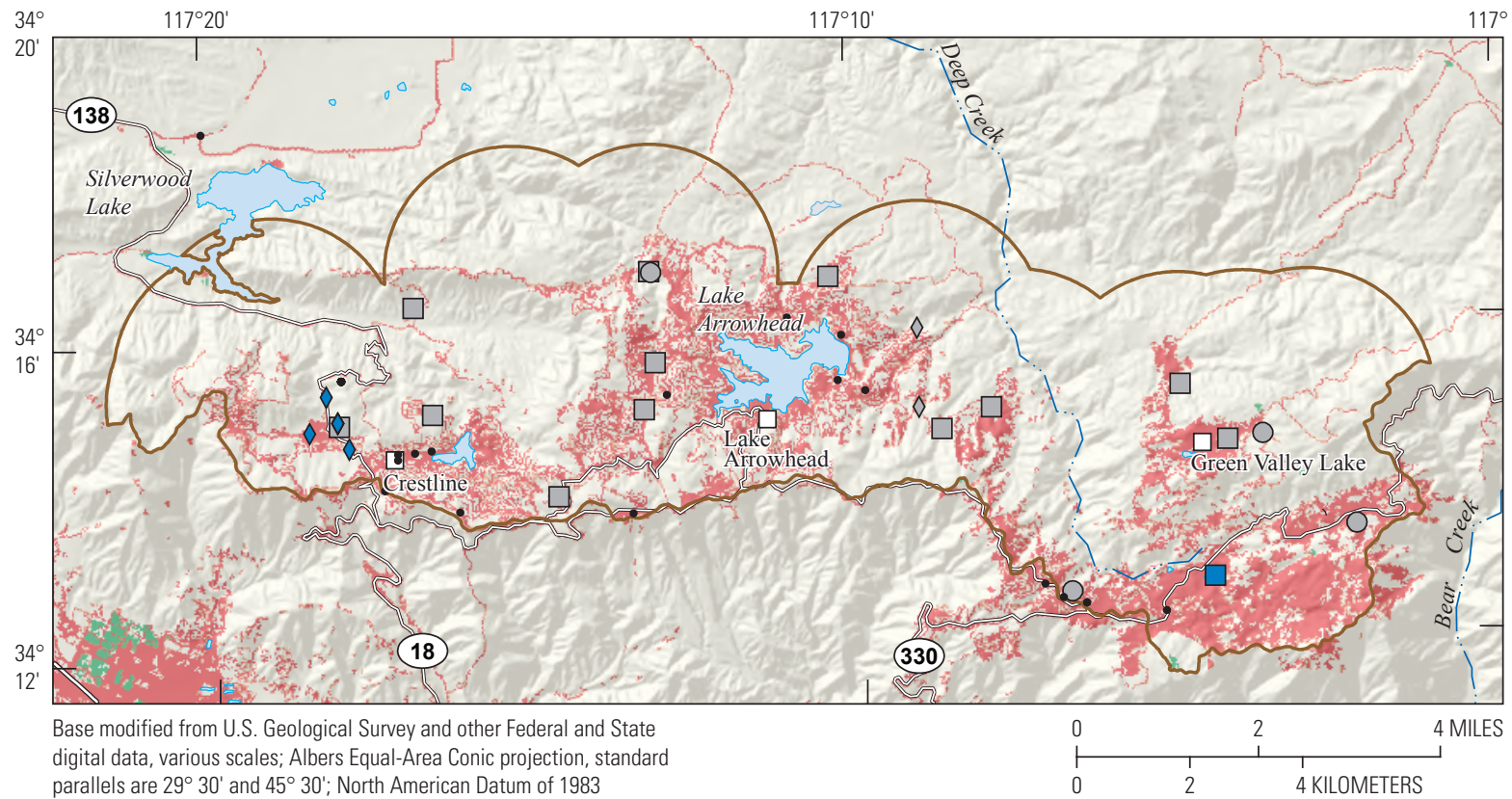

EXPLANATION
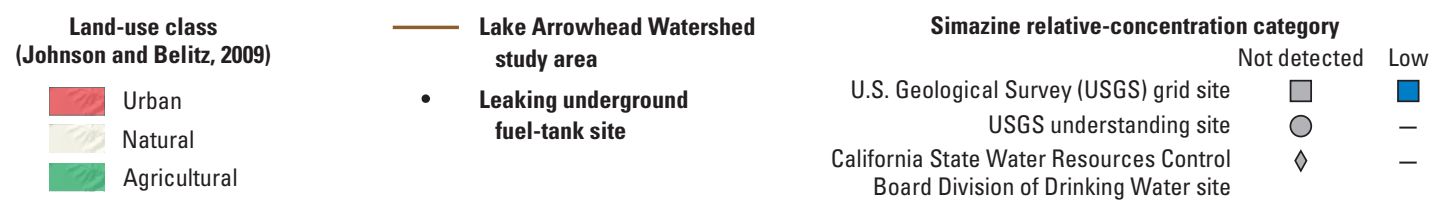

Figure 26. The 2001 land use and relative concentration of simazine in groundwater samples from U.S. Geological Survey (USGS) grid and understanding sites (2010) and for California Division of Drinking Water (SWRCB-DDW) sites (April 1, 2007-April 1, 2010) in two study areas of the California Groundwater Ambient Monitoring and Assessment (GAMA) Priority Basin Project: $A$, Bear Valley and $B$, Lake Arrowhead Watershed. 
$\boldsymbol{A}$

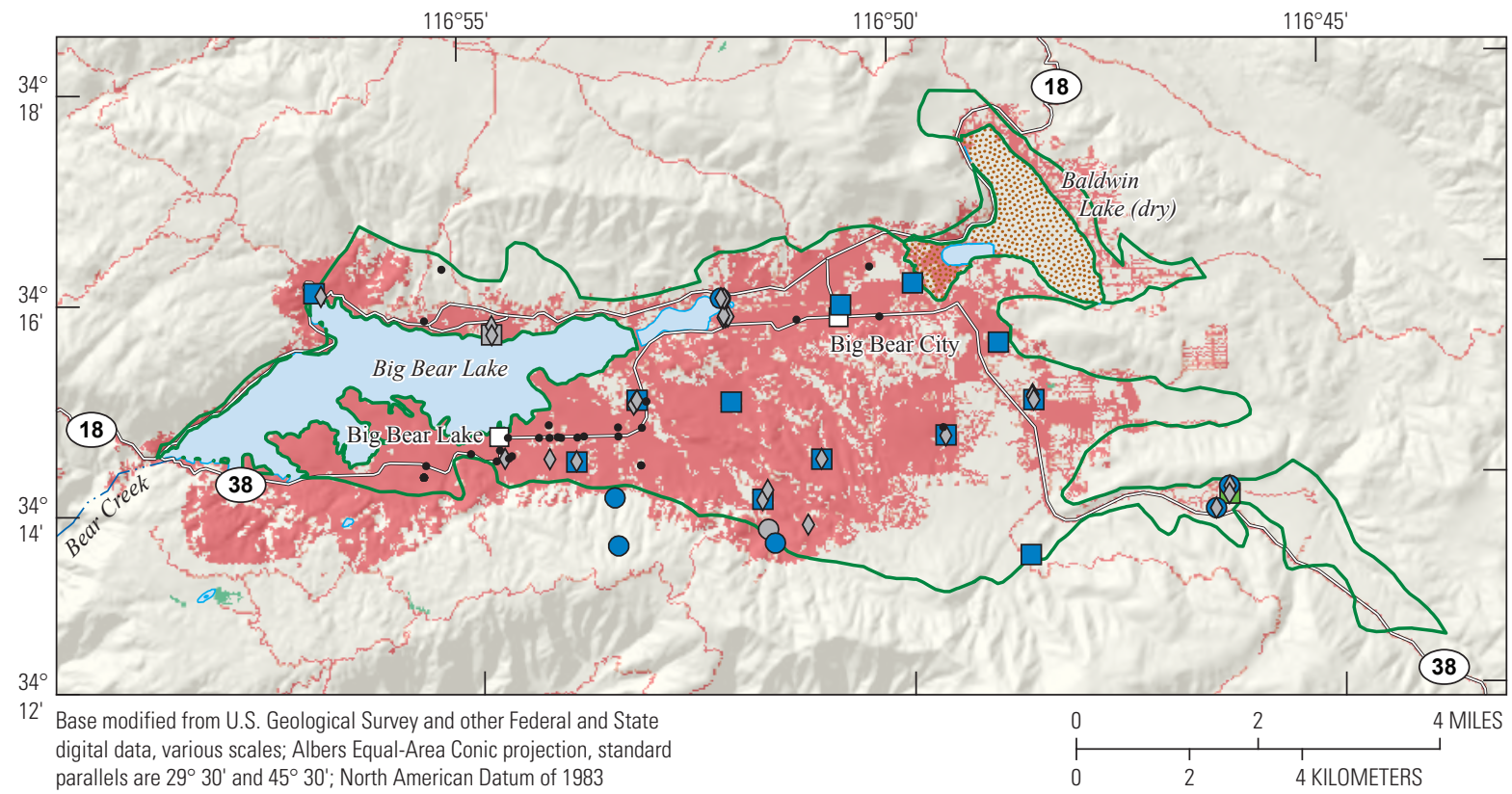

parallels are $29^{\circ} 30^{\prime}$ and $45^{\circ} 30^{\prime}$ ' North American Datum of 1983

EXPLANATION
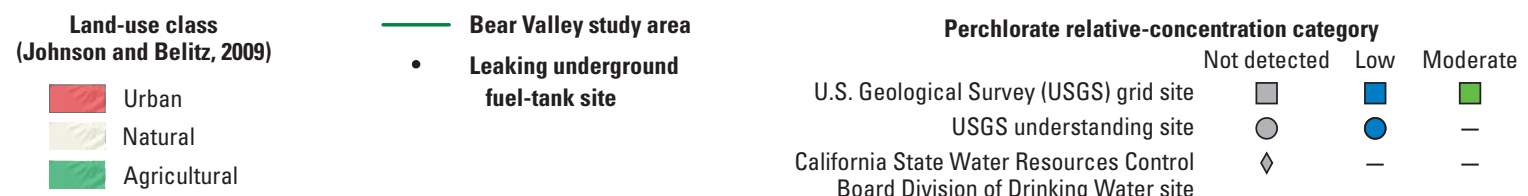

B

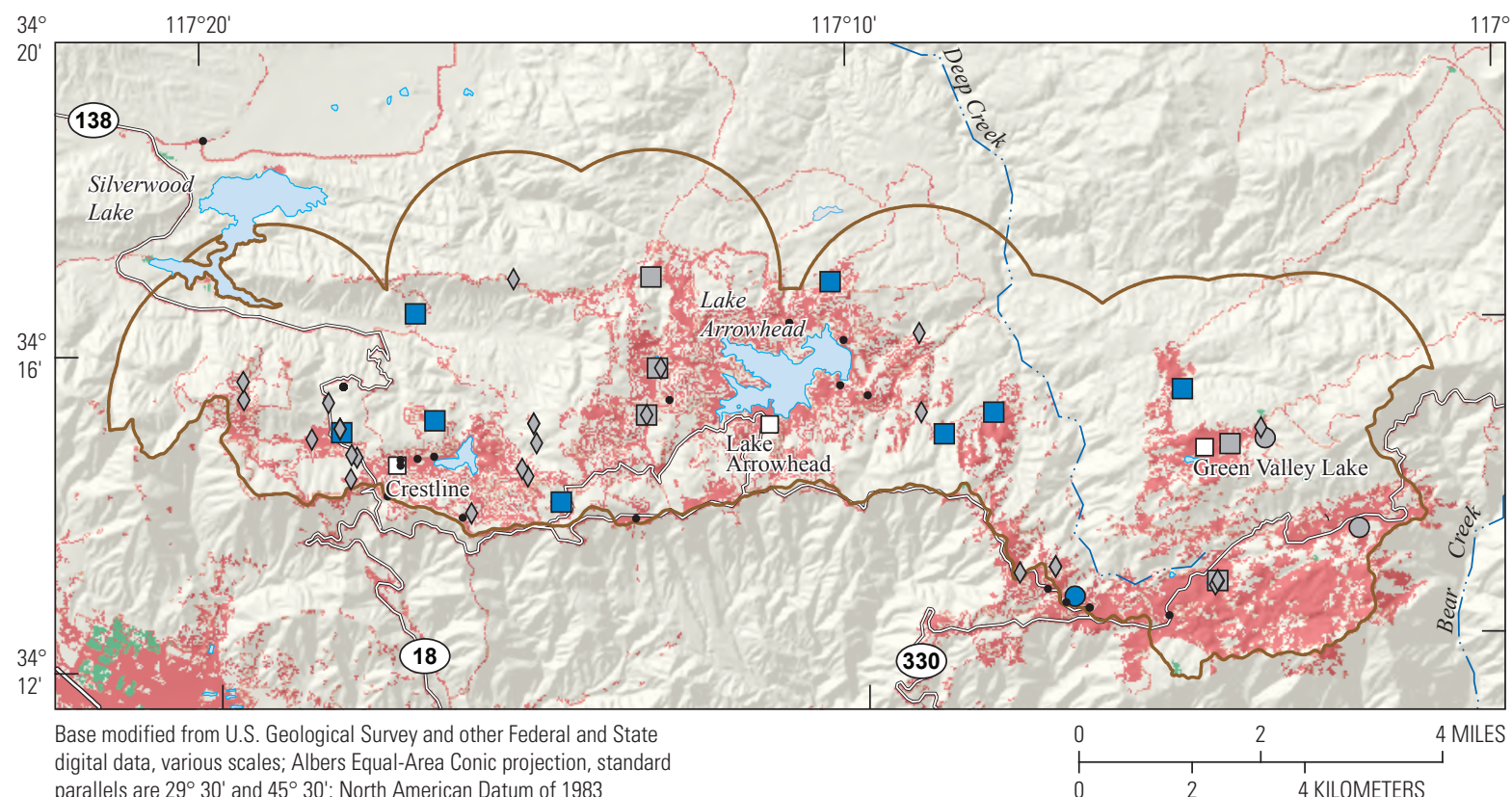

parallels are $29^{\circ} 30^{\prime}$ and $45^{\circ} 30^{\prime}$; North American Datum of 1983

EXPLANATION
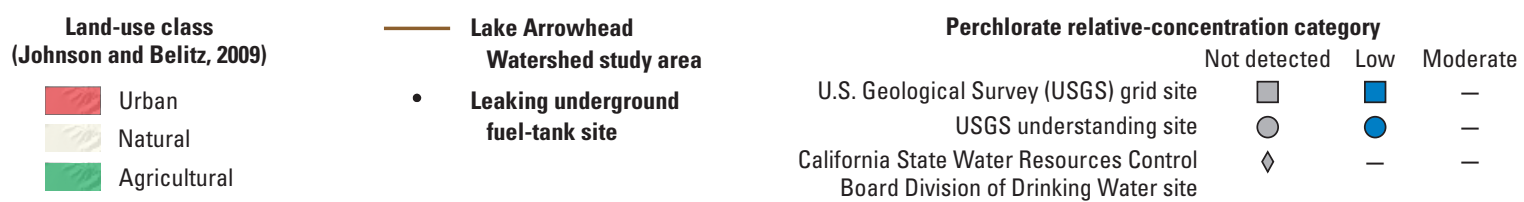

Figure 27. The 2001 land use and relative concentrations of perchlorate in groundwater samples from U.S. Geological Survey (USGS) grid and understanding sites (2010) and from California Division of Drinking Water (SWRCB-DDW) sites (April 1, 2007-April 1, 2010) in two study areas of the California Groundwater Ambient Monitoring and Assessment (GAMA) Priority Basin Project: $A$, Bear Valley and $B$, Lake Arrowhead Watershed. 


\section{Summary}

Groundwater quality in the approximately 112-squaremile Bear Valley and Lake Arrowhead Watershed (BEAR) study unit was investigated in cooperation with the California State Water Resources Control Board (SWRCB), as part of its Priority Basin Project of the Groundwater Ambient Monitoring and Assessment (GAMA) Program. The study unit is composed of two study areas (Bear Valley and Lake Arrowhead Watershed) in southern California in San Bernardino County. The GAMA Priority Basin Project was designed to assess the status of the quality of the groundwater resources, identify natural and human factors likely affecting groundwater quality, and monitor changes in groundwater quality. The sample collection protocols used in this study were designed to obtain representative samples of untreatedgroundwater quality in the primary aquifer used for public and community drinking-water supplies, not the treated drinking water delivered to consumers. The primary aquifer systems are defined by the depth of the perforated or open intervals of public-supply wells listed in the SWRCB Division of Drinking Water (DDW) water-quality database for each study area.

This report presented the following: a description of the hydrogeologic setting of the BEAR study unit, a study-unit assessment of the 2010 groundwater quality in the primary aquifer system, and a general understanding assessment to identify the natural and anthropogenic factors affecting groundwater quality in the primary aquifer system. The assessments are based on water-quality and ancillary data collected by the USGS from 38 sites (27 grid and 11 understanding), and on data from the SWRCB-DDW water-quality database. Potential relations with natural and anthropogenic factors were examined with statistical tests and graphical analyses and are discussed in the context of the hydrogeologic setting of the study unit.

Groundwater samples were analyzed for volatile organic compounds, pesticides and their degradates, and naturally present inorganic constituents, such as major ions and trace elements. Relative concentrations (RCs), which are the sample concentration divided by the health- or aestheticbased benchmark concentration, were used for evaluating groundwater quality for those constituents that have Federal or California regulatory or non-regulatory benchmarks for drinking-water quality. A RC greater than 1.0 indicates a concentration greater than a benchmark. Organic (volatile organic compounds and pesticides) and special-interest (perchlorate) constituent RCs were classified as "high" (RC greater than 1.0), "moderate" (RC less than or equal to 1.0 and greater than 0.1 ), or "low" (RC less than or equal to 0.1 ). For inorganic (radioactive, trace element, major ion, and nutrient) constituents, the boundary between low and moderate RCs was set at 0.5 .

Aquifer-scale proportion was used as the primary metric in the status assessment for evaluating groundwater quality at the study-unit scale or for its component areas. A stratified-random sampling design and grid-based statistical approach provided the basis for aquifer-scale proportions for individual constituents. The BEAR study unit was divided into two study areas, and each was stratified using a grid of cells: the Bear Valley study area (14 cells) and the Lake Arrowhead Watershed study area (13 cells). In each cell, one groundwater site (most often a well, but springs were also sampled) was randomly selected to represent the groundwater resource used for public supply. Aquifer-scale proportion is defined as the percentage of the primary aquifer with a specified range of $\mathrm{RC}$ for a particular constituent or class of constituents; the proportions are areal rather than volumetric. RCs greater than 1.0 (exceeding the corresponding water-quality benchmark) were categorized as high. The threshold between moderate and low RCs was 0.5 for inorganic constituents and 0.1 for organic constituents. Corresponding moderate and low aquifer-scale proportions are defined as the percentage of the primary aquifer for which RCs are moderate and low, respectively. The methods used to calculate aquifer-scale proportions are based on an equal-area grid; thus, the proportions are an areally weighted average proportion specific for each individual constituent or class of constituents. The understanding assessment used statistical correlations between concentrations of constituents and values of selected potential explanatory factors to identify the factors potentially affecting the concentration and distribution of constituents detected at high RCs or, for organic constituents, those for which a studyarea detection frequency was greater than 10 percent. The potential explanatory factors evaluated for the understanding assessment were land use, density of septic tanks, density of leaking (or formerly leaking) underground fuel tanks, site type, aquifer lithology, well depth and depth to the top of the perforated interval, elevation, aridity index, groundwater-age distribution, and the oxidation-reduction status (including $\mathrm{pH}$ and dissolved oxygen concentration).

Among the 44 inorganic constituents analyzed, 7 with health-based benchmarks were at moderate or high RCs. Of these seven, trace elements were at high RCs in 9.0 percent of the primary aquifer system of the Bear Valley study area and at moderate RCs in 13 percent. These aquifer-scale proportions for trace elements primarily reflected high RCs of fluoride (in 5.4 percent of the primary aquifer system) and arsenic (3.6 percent). In the Lake Arrowhead Watershed study area, RCs of inorganic constituents with health-based benchmarks (primarily radioactive constituents) were high in 25 percent of the primary aquifer system and moderate in 41 percent. These aquifer-scale proportions for radioactive constituents primarily reflected high RCs of radon-222 (in 62 percent of the primary aquifer system) and uranium (26 percent). The aquifer-scale proportions having high RCs of inorganic constituents with aesthetic-based benchmarks were 3.1 and 23 percent for the Bear Valley and Lake Arrowhead Watershed study areas, respectively, and the primary constituents were iron and manganese for both study areas. 
The RCs of organic constituents with health-based benchmarks were high in 1.0 percent of the primary aquifer system of the Bear Valley study area and moderate in 8.1 percent. Organic constituents with health-based benchmarks were detected in 79 and 54 percent of the primary aquifers in the Bear Valley and Lake Arrowhead Watershed study areas, respectively. Two groups of organic constituents and two individual organic constituents were detected in the study areas at frequencies greater than 10 percent of samples from the USGS grid sites: trihalomethanes (THMs), solvents, MTBE (methyl tert-butyl ether), and simazine for the Bear Valley study area and THMs for the Lake Arrowhead Watershed study area. Perchlorate was detected in samples from more than 10 percent of the USGS grid sites in both of the study areas.

In the Bear Valley study area, the high and moderate RCs of fluoride were likely due to interaction with geothermal systems. The high RC of arsenic was attributed to desorption of arsenic from aquifer sediments as a result of high $\mathrm{pH}$, anoxic reducing conditions, and long residence time in the aquifer. Trihalomethanes (THMs) in the Bear Valley study area were detected in samples from wells that were part of large urban water systems, but THMs were not detected in samples from the Lake Arrowhead Watershed, where the wells were part of small water systems. Understanding THM distribution was complicated by lack of correlation between THM concentrations and urban land use or septictank density. Solvents, MTBE, and simazine were detected at urban wells supplying older groundwater, but none of these organic constituents were measured at high RCs in more than 1 percent of the primary aquifer system. Comparison between the predicted and observed study-area detection frequencies of perchlorate indicated the detection frequency for concentrations at the method reporting level (85 percent) was much greater than the predicted range, indicating that anthropogenic sources could have contributed to low levels of perchlorate in the groundwater of the Bear Valley study area.

In the Lake Arrowhead Watershed study area, high and moderate RCs of radon-222 and uranium were attributed to older groundwater (recharged prior to 1952 or a mixture of old and younger recharge) from the granitic fractured-rock primary aquifer system. The presence of THMs at low RCs was associated with wells in small water systems. Similarities between the predicted and observed study-area detection frequencies of perchlorate indicated that natural sources were dominant in this study area, but RCs were uniformly low.

\section{References Cited}

Appelo, C.A.J., and Postma, Dieke, 2005, Geochemistry, groundwater and pollution ( $2 \mathrm{~d}$ ed.): Leiden, The Netherlands, A.A. Balkema Publishers, 649 p.

Arndt, M.F., 2010, Evaluation of gross alpha and uranium measurements for MCL compliance: Water Research Foundation, project 3028, 299 p., http://www.waterrf.org/PublicReportLibrary/3028.pdf.

Arrowhead Lake Association, 2011, Home Page: accessed December 13, 2011, at http://www.ala-ca.org.

Ayotte, J.D., Mrazik, B.R., Argue, D.M., and McGarry, F.J., 2004, Occurrence of methyl tert-butyl ether (MTBE) in public and private wells, Rockingham County, New Hampshire: U.S. Geological Survey Fact Sheet 2004-3119, 4 p., https://pubs.usgs.gov/fs/2004/3119/.

Ayotte, J.D., Flanagan, S.M., and Morrow, W.S., 2007, Occurrence of uranium and ${ }^{222}$ radon in glacial and bedrock aquifers in the Northern United States, 1993-2003: U.S. Geological Survey Scientific Investigations Report 2007-5037, 84 p., http://pubs.usgs.gov/sir/2007/5037/.

Barbash, J.E., Thelin, G.P., Kolpin, D.W., and Gilliom, R.J., 1999, Distribution of major herbicides in ground water of the United States: U.S. Geological Survey Water-Resources Investigations Report 98-4245, 57 p., http://water.usgs.gov/ nawqa/pnsp/pubs/wrir984245/wrir984245.pdf.

Belitz, Kenneth, Dubrovsky, N.M., Burow, Karen, Jurgens, Bryant, and Johnson, Tyler, 2003, Framework for a ground-water quality monitoring and assessment program for California: U.S. Geological Survey WaterResources Investigations Report 03-4166, 88 p., http://pubs.usgs.gov/wri/wri034166/.

Belitz, Kenneth, Jurgens, Bryant, Landon, M.K., Fram, M.S., and Johnson, Tyler, 2010, Estimation of aquifer scale proportion using equal area grids-Assessment of regional scale groundwater quality: Water Resources Research, v. 46, no. W11550, 14 p., http://onlinelibrary.wiley.com/ doi/10.1029/2010WR009321/epdf. 
Belitz, Kenneth, Fram, M.S., and Johnson, T.D., 2015, Metrics for assessing the quality of groundwater used for public-supply, CA, USA - Equivalent-population and area: Environmental Science and Technology, v. 49, no. 14, p. $8330-8338$.

Big Bear Chamber of Commerce, 2015, July 4th fireworks spectacular, weekend events and activities, accessed December 22, 2015, at http://www.bigbear.com/thingsto-do/special-events/4th-of-july/.

Big Bear Municipal Water District, 2011, Lake stabilizationIn-lieu water program, accessed December 12, 2011, at http://www.bbmwd.com/Lake_Stabilization.html.

Bryant, W.A., 1987, Cleghorn and related faults, San Bernardino County: California Division of Mines and Geology Fault Evaluation Report FER-187: California Division of Mines and Geology 13 p., accessed December 13, 2011, at ftp://ftp.consrv.ca.gov/pub/dmg/ shezp/FER_187/042887.pdf.

Bryant, W.A., compiler, 2003, Fault number 108b, Cleghorn fault zone, Northern Cleghorn section, in Quaternary Fault and Fold Database of the United States: U.S. Geological Survey, accessed December 15, 2011, at https://earthquake. usgs.gov/cfusion/qfault/show_report_AB_archive. cfm?fault_id $=108 \&$ section_id $=b$.

California Air Resources Board, 2003, §2262.6 Prohibition of MTBE and oxygenates other than ethanol in California gasoline starting December 31, 2003: California Code of Regulations, Title 13. Motor Vehicles, Division 3. Air Resources Board, Chapter 5. Standards for motor vehicle fuels, Article 1. Standards for gasoline, https://govt.westlaw. com/calregs/Document/ICE58BC30D46911DE8879F88E8 B0DAAAE? viewType $=$ FullText\&originationContext $=\mathrm{docu}$ menttoc\&transitionType $=$ CategoryPageItem $\&$ contextData $=$ (sc.Default).

California Air Resources Board, 2004, Monitoring sites with ambient toxics summaries-Methyl tertiary-butyl ether, accessed December 6, 2016, at http://www.arb.ca.gov/adam/ toxics/sitelists/mtbesites.html.

California Department of Public Health, 2003, Geologic controls on the distribution of radon in California, accessed January 5, 2015, at http://www.conservation.ca.gov/cgs/ minerals/hazardous_minerals/radon/Documents/Geo Controls_Dist_Radon.pdf.

California Department of Water Resources, 2003, California's groundwater update 2003: California Department of Water Resources Bulletin 118, 246 p., accessed August 2, 2011, at http://www.water.ca.gov/groundwater/bulletin118/index. $\mathrm{cfm}$.
California Department of Water Resources, 2004, California's groundwater-Individual basin descriptions, Bear Valley Groundwater Basin: California Department of Water Resources Bulletin 118, accessed November 25, 2011, at http://www.water.ca.gov/pubs/groundwater/bulletin_118/ basindescriptions/8-9.pdf.

California Department of Water Resources, 2011a, California State Water Project today, accessed December 5, 2011, at http://www.water.ca.gov/swp/swptoday.cfm.

California Department of Water Resources, 2011b, Locations: Silverwood Lake, accessed December 5, 2011, at http://www.water.ca.gov/recreation/locations/silverwood/.

California Department of Water Resources, 2016, Groundwater Information Center, accessed September 2016, at http://www.water.ca.gov/groundwater/gwinfo/.

California State Water Resources Control Board, 1995, California leaking underground fuel tank (LUFT) historical case analysis, Environmental Protection Department, 65 p., accessed March 22, 2017, at http://www.swrcb.ca.gov/ust/cleanup/docs/lnlplum.pdf.

California State Water Resources Control Board, 2003, Report to the Governor and Legislature-A comprehensive groundwater quality monitoring program for California, Assembly Bill 599, March 2003, 121 p., accessed July 29, 2011, at http://www.waterboards.ca.gov/gama/docs/final_ ab_599_rpt_to_legis_7_31_03.pdf.

California State Water Resources Control Board, 2015, Drinking water source identification number (PS Code), name and type: California State Water Resources Control Board database, accessed September 15, 2015, at http://www.waterboards.ca.gov/drinking_water/certlic/ drinkingwater/EDTlibrary.shtml.

City of Big Bear Lake, 2010, Annual report-Fiscal year ending June 30, 2010: City of Big Bear Lake, Department of Water and Power, 38 p., accessed January 11, 2017, at http://www.bbldwp.com/ArchiveCenter/ViewFile/Item/105.

Dasgupta, P.K., Martinelango, P.K., Jackson, W.A., Anderson, T.A., Tian, Kang, Tock, R.W., and Rajagopalan, Srinath, 2005, The origin of naturally occurring perchlorate-The role of atmospheric processes: Environmental Science and Technology, v. 39, p. 1569 1575, http://pubs.acs.org/doi/pdf/10.1021/es048612x.

Dubrovsky, N.M., Kratzer, C.R., Brown, L.R., Gronberg, J.M., and Burow, K.R., 1998, Water quality in the San Joaquin-Tulare Basins, California, 1992-95: U.S. Geological Survey Circular 1159, p. 38, http://pubs.usgs.gov/circ/circ1159/circ1159.pdf. 
Dubrovsky, N.M., Burow, K.R., Clark, G.M., Gronberg, J.M., Hamilton, P.A., Hitt, K.J., Mueller, D.K., Munn, M.D., Nolan, B.T., Puckett, L.J., Rupert, M.G., Short, T.M., Spahr, N.E., Sprague, L.A., and Wilber, W.G., 2010, The quality of our Nation's waters-Nutrients in the Nation's streams and groundwater, 1992-2004: U.S. Geological Survey Circular 1350, 174 p., http://pubs.usgs.gov/circ/1350/.

Edmunds, W.M., and Smedley, P.L., 2013, Fluoride in natural waters, in Alloway, B.J., Centeno, J.A., Finkelman, R.B., Fuge, Ronald, Lindh, Ulf, Smedley, P.L., Selinus, Olle, eds., Essentials of medical geology (revised ed.): The Netherlands, Springer, p. 311-336, https://link.springer. com/chapter/10.1007\%2F978-94-007-4375-5_13.

Extension Toxicology Network, 1993, Pesticide Information Profile: Simazine: accessed March 14, 2017, at http://pmep. cce.cornell.edu/profiles/extoxnet/pyrethrins-ziram/simazineext.html.

Flanagan, S.M., Ayotte, J.D., and Robinson, G.R., Jr., 2012, Quality of water from Crystalline Rock Aquifers in New England, New Jersey, and New York, 1995-2007: U.S. Geological Survey Scientific Investigations Report 2011-5220, 104 p., http://pubs.usgs.gov/sir/2011/5220.

Flint, L.E., and Flint, A.L., 2007, Regional analysis of ground-water recharge: U.S. Geological Survey Professional Paper 1703-B, p. 29-60, https://pubs.er.usgs.gov/publication/pp1703B.

Flint, L.E., and Martin, Peter, eds., with contributions by Brandt, Justin, Christensen, A.H., Flint, A.L., Flint, L.E., Hevesi, J.A., Jachens, Robert, Kulongoski, J.T., Martin, Peter, and Sneed, Michelle, 2012, Geohydrology of Big Bear Valley, California-Phase 1-Geologic framework, recharge, and preliminary assessment of the source and age of groundwater: U.S. Geological Survey Scientific Investigations Report 2012-5100, 112 p., http://pubs.usgs.gov/sir/2012/5100/.

Fram, M.S., and Belitz, Kenneth, 2011, Probability of detecting perchlorate under natural conditions in deep groundwater in California and the southwestern United States: Environmental Science and Technology, v. 45, no. 4, p. 1271-1277, http://pubs.acs.org/doi/abs/10.1021/es103103p.

Fram, M.S., and Belitz, Kenneth, 2012, Status and understanding of groundwater quality in the TahoeMartis, Central Sierra, and Southern Sierra study units, 2006-2007-California GAMA Priority Basin Project: U.S. Geological Survey Scientific Investigations Report 2011-5216, 222 p., http://pubs.usgs.gov/sir/2011/5216/.
Fram, M.S., and Belitz, Kenneth, 2014, Status and understanding of groundwater quality in the Sierra Nevada Regional study unit, 2008 - California GAMA Priority Basin Project: U.S. Geological Survey Scientific Investigations Report 2014-5174, 118 p., https://doi.org/10.3133/sir20145174.

Frankenberger, W.T., Jr., ed., 2002, Environmental chemistry of arsenic: New York, N.Y., Marcel Dekker, Inc., 391 p.

Frost, B.R., Barnes, C.G., Collins, W.J., Arculus, R.J., Ellis, D.J., and Frost, C.D., 2001, A geochemical classification for granitic rocks: Journal of Petrology, v. 42, no. 11, p. 2033-2048, http://petrology.oxfordjournals.org/ content/42/11/2033.full.pdf+html.

GEOSCIENCE Support Services, Inc., 2006, Geohydrologic evaluation of nitrate in ground water in the Lake William area, Baldwin Lake watershed, March 17, 2006: Official Report, $22 \mathrm{p}$.

GEOSCIENCE Support Services, Inc., 2008, Lake Arrowhead Community Services District results of drilling, construction, development and testing LACSD well no. 8, June 25, 2008: Official Well Report, 15 p.

Gilliom, R.J., 2007, Pesticides in U.S. streams and groundwater: Environmental Science and Technology, v. 41, no. 10, p. 3408-3414, http://water.usgs.gov/nawqa/pnsp/ pubs/files/051507.ESTfeature_gilliom.pdf.

Gilliom, R.J., Barbash, J.E., Crawford, C.G., Hamilton, P.A., Martin, J.D., Nakagaki, Naomi, Nowell, L.H., Scott, J.C., Stackelberg, P.E., Thelin, G.P., and Wolock, D.M., 2006, The quality of our nation's waters-Pesticides in the nation's streams and ground water, 1992-2001: U.S. Geological Survey Circular 1291, 172 p., http://pubs.usgs.gov/circ/2005/1291/pdf/circ1291_front.pdf.

Gunasekara, A.S., 2004, Environmental fate of simazine: California Environmental Protection Agency, Department of Pesticide Regulation, Environmental Monitoring Branch, 36 p., http://www.cdpr.ca.gov/docs/emon/pubs/fatememo/ simazine.pdf.

Harden, S.L., Chapman, M.J., and Harned, D.A., 2009, Characterization of groundwater quality based on regional geologic setting in the Piedmont and Blue Ridge Physiographic Provinces, North Carolina: U.S. Geological Survey Scientific Investigations Report 2009-5149, 32 p., https://pubs.er.usgs.gov/publication/sir20095149.

Helsel, D.R., and Hirsch, R.M., 2002, Statistical methods in water resources: U.S. Geological Survey Techniques of Water-Resources Investigations, book 4, chap. A3, 522 p., http://water.usgs.gov/pubs/twri/twri4a3/. 
Hem, J.D., 1985, Study and interpretation of the chemical characteristics of natural water ( $3 \mathrm{~d}$ ed.): U.S. Geological Survey Water-Supply Paper 2254, 263 p., http://pubs.er.usgs.gov/publication/wsp2254.

Hirsch, R.M., Alley, W.M., and Wilber, W.G., 1988, Concepts for a national water-quality assessment program: U.S. Geological Survey Circular 1021, 42 p., https://pubs.er.usgs.gov/publication/cir1021.

Isaaks, E.H., and Srivastava, R.M., 1989, Applied geostatistics: New York, N.Y., Oxford University Press, $511 \mathrm{p}$.

Ivahnenko, Tammy, and Barbash, J.E., 2004, Chloroform in the hydrologic system-Sources, transport, fate, occurrence, and effects on human health and aquatic organisms: U.S. Geological Survey Scientific Investigations Report 2004-5137, 34 p., http://pubs.usgs.gov/sir/2004/5137/.

Jennings, C.W., 1977, Geologic map of California: California Department of Conservation, Division of Mines and Geology Geologic Data Map No. 2, scale 1:750,000.

Johnson, T.D., and Belitz, Kenneth, 2009, Assigning land use to supply wells for the statistical characterization of regional groundwater quality — Correlating urban land use and VOC occurrence: Journal of Hydrology, v. 370, no. 1-4, p. 100-108, http://www.sciencedirect.com/science/article/ pii/S0022169409001462.

Jurgens, B.C., McMahon, P.B., Chapelle, F.H., and Eberts, S.M., 2009, An Excel ${ }^{\circledR}$ workbook for identifying redox processes in ground water: U.S. Geological Survey Open-File Report 2009-1004, 8 p., https://pubs.usgs.gov/of/2009/1004/.

Kegley, S.E., Hill, B.R., Orme, Stephan, and Choi, A.H., 2014, PAN Pesticide Database (ver. 11.0): Oakland, Calif., Pesticide Action Network, North America, accessed April 9, 2015, at http://www.pesticideinfo.org.

Klepper, M.R., and Wyant, D.G., 1957, Notes on the geology of uranium: U.S. Geological Survey Bulletin 1046-F, 72 p., https://pubs.usgs.gov/bul/1046f/report.pdf.

Krishnaswami, Sethunathasarma., Graustein, W.C., Turekian, K.K., and Dowd, J.F., 1982, Radium, thorium and radioactive lead isotopes in groundwaters-Application to the in situ determination of adsorption-desorption rate constants and retardation factors: Water Resources Research, v. 18, no. 6, p. 1663-1675, http://onlinelibrary. wiley.com/doi/10.1029/WR018i006p01663/epdf.
Kulongoski, J.T., Belitz, Kenneth, Landon, M.K., and Farrar, Christopher, 2010, Status and understanding of groundwater quality in the North San Francisco Bay groundwater basins, 2004 - California GAMA Priority Basin Project: U.S. Geological Survey Scientific Investigations Report 2010-5089, 88 p., https://pubs.usgs.gov/sir/2010/5089.

Lake Arrowhead Community Services District, 2011a, About LASCD: History, accessed January 7, 2016, at http://www.lakearrowheadcsd.com/about-lacsd-2/history/.

Lake Arrowhead Community Services District, 2011b, About LASCD: Our Water-Water Sources, accessed January 7, 2016, at http://www.lakearrowheadcsd.com/ about-lacsd-2/our-water/water-sources/.

LaMotte, Andrew, 2008, National Land Cover Database 2001 (NLCD01), Tile 3, Southwest United States, NLCD01_3: U.S. Geological Survey Data Series $38 \overline{3}-\mathrm{C}$, accessed June 12, 2015, at https://pubs.er.usgs.gov/publication/ds383C.

Mathany, T.M., and Belitz, Kenneth, 2013, Groundwaterquality data in the Bear Valley and selected Hard Rock Areas study unit, 2010 - Results from the California GAMA Program: U.S. Geological Survey Data Series 747, 86 p., https://pubs.usgs.gov/ds/747/.

McMahon, P.B., and Chapelle, F.H., 2008, Redox processes and water quality of selected principal aquifer systems: Groundwater, v. 46, no. 2, p. 259-271, http://onlinelibrary. wiley.com/doi/10.1111/j.1745-6584.2007.00385.x/full.

Michel, R.L., 1989, Tritium deposition in the continental United States, 1953-1983: U.S. Geological Survey Water-Resources Investigations Report 89-4072, 46 p., https://pubs.er.usgs.gov/publication/wri894072.

Moran, M.J., Zogorski, J.S., and Squillance, P.J., 2005, MTBE and gasoline hydrocarbons in ground water of the United States: Groundwater, v. 43, no. 4, p. 615-627, http://onlinelibrary.wiley.com/doi/10.1111/j.17456584.2005.0113.x/full.

Moran, M.J., Zogorski, J.S., and Squillance, P.J., 2007, Chlorinated solvents in groundwater of the United States: Environmental Science and Technology, v. 41, no. 1, p. 74-81, http://pubs.acs.org/doi/pdf/10.1021/es061553y.

Munster, Jennie, and Hanson, G.N., 2009, Perchlorate and ion chemistry of road runoff: Environmental Chemistry, v. 6 , no. 1 , p. $28-35$, https://www.researchgate.net/ publication/228502976_Perchlorate_and_ion_chemistry_ of_road_runoff. 
National Cooperative Highway Research Program, 2005, NCHRP synthesis 344: Winter highway operations, a synthesis of highway practice: Washington D.C., Transportation Research Board, 76 p., http://onlinepubs.trb. org/onlinepubs/nchrp/nchrp_syn_344.pdf.

National Research Council, 2006, Fluoride in drinking water-A scientific review of EPA's standards: Washington, D.C., The National Academies Press, 530 p., http:/www.actionpa.org/fluoride/nrc/NRC-2006.pdf.

Navarro, Simón, Vela, Nuria, Giménez, M.J., and Navarro, Ginés, 2004, Persistence of four $s$-triazine herbicides in river, sea and groundwater samples exposed to sunlight and darkness under laboratory conditions: Science of The Total Environment, v. 329, no. 1-3, p. 87-97, accessed December 29, 2016, at http://dx.doi.org/10.1016/j.scitotenv.2004.03.013.

Nolan, B.T., and Hitt, K.J., 2003, Nutrients in shallow ground waters beneath relatively undeveloped areas in the conterminous United States: U.S. Geological Survey Water-Resources Investigations Report 2002-4289, 17 p., https://pubs.usgs.gov/wri/wri024289/.

Nordstrom, D.K., and Jenne, E.A., 1977, Fluorite solubility equilibria in selected geothermal waters: Geochimica et Cosmochimica Acta, v. 41, no. 2, p. 175-188, accessed January 10, 2017, at http://dx.doi.org/10.1016/0016-7037(77)90224-1.

Otton, J.K., 1992, The geology of radon: U.S. Geological Survey General Interest Publication, 28 p., https://pubs.usgs.gov/gip/7000018/report.pdf.

Parker, D.R., Seyfferth, A.L., and Kiel Reese, Brandi, 2008, Perchlorate in groundwater-A synoptic survey of "pristine" sites in the coterminous United States: Environmental Science and Technology, v. 42, no. 5, p. 1465-1471, http://pubs.acs.org/doi/abs/10.1021/es7021957.

Parsons, M.C., Kulongoski, J.T., and Belitz, Kenneth, 2014, Status and understanding of groundwater quality in the South Coast Interior Groundwater Basins, 2008-California GAMA Priority Basin Project: U.S. Geological Survey Scientific Investigations Report 2014-5023, 68 p., https://pubs.usgs.gov/sir/2014/5023/pdf/sir2014-5023.pdf.

Paul, A.P., Seiler, R.L., Rowe, T.G., and Rosen, M.R., 2007, Effects of agriculture and urbanization on quality of shallow ground water in the arid to semiarid western United States, 1993-2004: U.S. Geological Survey Scientific Investigations Report 2007-5179, 56 p., https://pubs.usgs.gov/sir/2007/5179/pdf/sir20075179.pdf.

Petrisor, I.G., and Wells, J.T., 2008, Tracking chlorinated solvents in the environment: Environmental Forensics, no. 26 , p. 130-152.
Plummer, L.N., Böhlke, J.K., and Doughten, M.W., 2006, Perchlorate in pleistocene and holocene groundwater in North-Central New Mexico: Environmental Science and Technology, v. 40, no. 6, p. 1757-1763, http://pubs.acs.org/doi/pdf/10.1021/es051739h.

Previtali, K.J., 2002, Fluoride issue addressed by CSD: Big Bear Grizzly, April 3, 2002, accessed January 10, 2017, at http://www.bigbeargrizzly.net/fluoride-issue-addressed-bycsd/article_cfbf41a1-10e3-5e8b-bd04-6a4b311e44a9.html.

PRISM Climate Group, 2012, United States average annual precipitation, maximum and minimum temperature, 19712000: Oregon State University, PRISM website, accessed August 9, 2012, at http://prism.oregonstate.edu/.

Rajagopalan, Srinath, Anderson, Todd, Cox, Stephen, Harvey, Greg, Cheng, Qiuqiong, and Jackson, W.A., 2009, Perchlorate in wet deposition across North America: Environmental Science and Technology, v. 43, no. 3, p. 616-622, http://pubs.acs.org/doi/pdf/10.1021/es801737u.

Rausser, G.C., Adams, G.D., Montgomery, W.D., and Smith, A.E., 2004, The social costs of an MTBE ban in California: Giannini Foundation Research Report 349, 68 p., http://giannini.ucop.edu/ResearchReports/349_ MTBE.pdf.

Rowe, B.L., Toccalino, P.L., Moran, M.J., Zogorski, J.S., and Price, C.V., 2007, Occurrence and potential humanhealth relevance of volatile organic compounds in drinking water from domestic wells in the United States: Environmental Health Perspectives, v. 115, no. 11, p. 1539-1546, http://www.ncbi.nlm.nih.gov/pmc/articles/ PMC2072842/pdf/ehp0115-001539.pdf.

Saucedo, G.J., Bedford, D.R., Raines, G.L., Miller, R.J., and Wentworth, C.M., 2000, GIS data for the geologic map of California: California Department of Conservation, Division of Mines and Geology, CD-ROM 2000-007, scale 1:750,000, http://www.conservation.ca.gov/cgs/ information/publications/pub_index/Pages/statewide references.aspx\#statewide.

Scott, J.C., 1990, Computerized stratified random siteselection approaches for design of a ground-water-quality sampling network: U.S. Geological Survey WaterResources Investigations Report 90-4101, 109 p., https://pubs.er.usgs.gov/publication/wri904101.

Shelton, J.L., 2005, Assessment of shallow groundwater quality in recently urbanized areas of Sacramento, California, 1998: U.S. Geological Survey Scientific Investigations Report 2005-5148, 51 p., https://pubs.usgs.gov/sir/2005/5148/. 
Smedley, P.L., and Kinniburgh, D.G., 2002, A review of the source, behavior and distribution of arsenic in natural waters: Applied Geochemistry, v. 17, no. 5, p. 517-568, http://www.sciencedirect.com/science/article/pii/ S0883292702000185.

Sparks, D.L., 1995, Environmental soil chemistry: San Diego, Calif., Academic Press, 353 p.

State of California, 1999, Supplemental report of the 1999 Budget Act 1999-00 fiscal year, Item 3940-001-0001: State Water Resources Control Board, accessed July 7 , 2015, at http://www.lao.ca.gov/1999/99-00_supp_rpt_lang. html\#3940.

State of California, 2001a, Assembly Bill No. 599, Chapter 522, accessed July 7, 2015, at http://www.swrcb. ca.gov/gama/docs/ab_599_bill_20011005_chaptered.pdf.

State of California, 2001b, Groundwater Monitoring Act of 2001: California Water Code, part 2.76, Groundwater Quality Monitoring, sec. 10780-10782.3, accessed July 7, 2015, at http://leginfo.legislature.ca.gov/faces/codes displayText.xhtml? lawCode $=$ WAT \&division $=6 . \&$ title $=\&$ par $\mathrm{t}=2.76 . \&$ chapter $=\&$ article $=$.

Stumm, Werner, and Morgan, J.J., 1996, Aquatic chemistryChemical equilibria and rates in natural waters: New York, N.Y., John Wiley \& Sons, 1022 p.

Szabo, Zoltan, DePaul, V.T., Fischer, J.M., Kraemer, E.J., and Jacobsen, Eric, 2012, Occurrence and geochemistry of radium in water from principal drinking-water aquifer systems of the United States: Applied Geochemistry, v. 27, no. 3, p. 729-752, http://www.sciencedirect.com/science/ article/pii/S0883292711004471.

Thomas, J.M., Welch, A.H., Lico, M.S., Hughes, J.L., and Whitney, Rita, 1993, Radionuclides in groundwater of the Carson River Basin, western Nevada and eastern California, USA: Applied Geochemistry, v. 8, p. 447-471.

TIBCO Software Inc., 2008, TIBCO Spotfire $\mathrm{S}+{ }^{\circledR}$ 8.1, Guide to Statistics, v. 1, accessed February 19, 2016, at http:// www-personal.umich.edu/ yryamada/statman 1.pdf.

Toccalino, P.L., and Norman, J.E., 2006, Health-based screening levels to evaluate U.S. Geological Survey ground water quality data: Risk Analysis, v. 26, no. 5, p. 13391348, http://infotrek.er.usgs.gov/docs/nawqa_www/HBSL/ reports/Toccalino.Norman.HBSL.RiskAnalysis.pdf.

Toccalino, P.L., Norman, J.E., Phillips, R.H., Kauffman, L.J., Stackelberg, P.E., Nowell, L.H., Krietzman, S.J., and Post, G.B., 2004, Application of health-based screening levels to ground-water quality data in a state-scale pilot effort: U.S. Geological Survey Scientific Investigations Report 2004-5174, 64 p., https://pubs.usgs.gov/sir/2004/5174/.
Toccalino, P.L., Norman, J.E., and Schoephoester, K.M., 2014, Health-based screening levels for evaluating water-quality data: U.S. Geological Survey, http://water.usgs.gov/nawqa/HBSL.

Troiano, John, Weaver, Don, Marade, Joe, Spurlock, Frank, Pepple, Mark, Nordmark, Craig, and Bartkowiak, Donna, 2001, Summary of well water sampling in California to detect pesticide residues resulting from nonpoint-source applications: Journal of Environmental Quality, v. 30, p. 448-459, http://www.cdpr.ca.gov/docs/emon/pubs/ ehapref/pestrs01.pdf.

United Nations Educational, Scientific, and Cultural Organization (UNESCO), 1979, Map of the world distribution of arid regions - Explanatory note: MAB Technical Notes, v. 7, 54 p., http://unesdoc.unesco.org/ images/0003/000326/032661eo.pdf.

United Nations Environment Programme, 1997, World Atlas of Desertification ( $2 \mathrm{~d}$ ed.): London, Edward Arnold, 182 p.

U.S. Centers for Disease Control and Prevention and U.S. Department of Housing and Urban Development, 2006, Chapter 8: Rural water supplies and water-quality issues, in Health Housing Reference Manual: Atlanta, Ga., U.S. Department of Health and Human Services, http://www.cdc.gov/nceh/publications/books/housing/ housing_ref_manual_2012.pdf.

U.S. Department of Agriculture, 2013, Watershed boundary dataset: United States Department of Agriculture-Natural Resources Conservation Service, United States Geological Survey, and the Environmental Protection Agency, accessed January 7, 2016, at https://gdg.sc.egov.usda.gov/GDGOrder.aspx.

U.S. Department of Commerce, 2011, National Temperature and Precipitation Maps: National Climatic Data Center, accessed July 26, 2011, at http://www.ncdc.noaa.gov/oa/ncdc.html.

U.S. Environmental Protection Agency, 1986, Guidelines for the health risk assessment of chemical mixtures: U.S. Environmental Protection Agency, Office of Research and Development, Risk Assessment Forum EPA 630-R-98002, September 1986, 28 p., accessed December 19, 2016, at https://www.epa.gov/sites/production/files/2014-11/ documents/chem_mix_1986.pdf.

U.S. Environmental Protection Agency, 2006, 2006 Edition of the drinking water standards and health advisories: Washington, D.C., U.S. Environmental Protection Agency, Office of Water EPA 822-R-06-013, accessed March 4, 2015, at http://nepis.epa.gov/Exe/ZyPDF.cgi/P1004X78. PDF?Dockey=P1004X78.PDF. 
U.S. Environmental Protection Agency, 2009a, 2009 Edition of the drinking water standards and health advisories: Washington, D.C., U.S. Environmental Protection Agency, Office of Water EPA 822-R-09-011, 18 p., https://nepis.epa.gov/Exe/ZyPDF.cgi/P1005P2B. PDF?Dockey=P1005P2B.PDF.

U.S. Environmental Protection Agency, 2009b, National primary drinking water regulations, accessed January 6, 2016, at http://www.epa.gov/your-drinking-water/tableregulated-drinking-water-contaminants.

U.S. Environmental Protection Agency, 2011, Perchlorate in the Pacific Southwest: California, accessed December 5, 2014, at http://archive.epa.gov/region9/toxic/web/html/ index-6.html.

U.S. Environmental Protection Agency, 2013, Drinking water contaminants - Standards and regulations, accessed March 4, 2015, at http://water.epa.gov/drink/contaminants/.

U.S. Environmental Protection Agency, 2015a, Technology Transfer Network-Air toxics web site, arsenic compounds, accessed January 6, 2016, at https://www.epa.gov/haps/ health-effects-notebook-hazardous-air-pollutants.

U.S. Environmental Protection Agency, 2015b, Technology Transfer Network-Air toxics web site, vinyl chloride, accessed July 18, 2014, at https:/www.epa.gov/haps/healtheffects-notebook-hazardous-air-pollutants.

U.S. Geological Survey, 1961, Distribution of uranium in rocks and minerals of Mesozoic batholiths in western United States: U.S. Geological Survey Bulletin 1070-C, 103 p., https://pubs.usgs.gov/bul/1070c/report.pdf.

U.S. Geological Survey, 1999, The quality of our Nation's waters-Nutrients and pesticides: U.S. Geological Survey Circular 1225, 82 p., https://pubs.usgs.gov/circ/circ1225/index.html.

Vinson, D.S., Vengosh, Avner, Hirschfeld, Daniella, and Dwyer, G.S., 2009, Relationships between radium and radon occurrence and hydrochemistry in fresh groundwater from fractured crystalline rocks, North Carolina (USA): Chemical Geology, v. 260, no. 3-4, p. 159-171, http://www. sciencedirect.com/science/article/pii/S0009254108004920.

Waller, R.M., 1988, Ground water and the rural homeowner: U.S. Geological Survey, Reston, Va., http://pubs.usgs.gov/gip/gw_ruralhomeowner/.

Welch, A.H., Lico, M.S., and Hughes, J.L., 1988, Arsenic in ground water of the western United States: Ground Water, v. 26, no. 3, p. 333-347, http://onlinelibrary.wiley.com/ doi/10.1111/j.1745-6584.1988.tb00397.x/epdf.
Welch, A.H., Oremland, R.S., Davis, J.A., and Watkins, S.A., 2006, Arsenic in ground water-A review of current knowledge and relation to the CALFED solution area with recommendations for needed research: San Francisco Estuary \& Watershed Science, v. 4, no. 2, 32 p., http://repositories.cdlib.org/jmie/sfews/vol4/iss2/art4/.

Western Regional Climate Center, 2011, Western Regional Climate Center, summary climate data for Southern California, average monthly climate summary, accessed December 2, 2011, at http://www.wrcc.dri.edu/summary/Climsmsca.html.

Williams, Pamela, Benton, Laurie, Warmerdam, John, and Sheehan, Patrick, 2002, Comparative risk analysis of six volatile organic compounds in California drinking water: Environmental Science and Technology, v. 36, no. 22, p. 4721-4728, http://pubs.acs.org/doi/pdf/10.1021/es020725y.

Wood, W.W., Kraemer, T.F., and Shapiro, Allen, 2004, Radon $\left({ }^{222} \mathrm{Rn}\right)$ in ground water of fractured rocks-A diffusion/ ion exchange model: Groundwater, v. 42, no. 4, p. 552-567, accessed January 4, 2017, at http://onlinelibrary.wiley.com/ doi/10.1111/j.1745-6584.2004.tb02624.x/epdf.

Wright, M.T., and Belitz, Kenneth, 2011, Status and understanding of groundwater quality in the San Diego Drainages Hydrogeologic Province, 2004-California GAMA Priority Basin Project: U.S. Geological Survey Scientific Investigations Report 2011-5154, 71 p., http://pubs.usgs.gov/sir/2011/5154/.

Zapecza, O.S., and Szabo, Zoltan, 1988, Natural radioactivity in groundwater-A review, in Moody, D.W., Carr, Jerry, Chase, E.B., and Paulson, R.W. National Water Summary 1986-Hydrologic Events and Ground-Water Quality: U.S. Geological Survey Water Supply Paper 2325, p. 50-57, http://pubs.usgs.gov/wsp/2325/report.pdf.

Zogorski, J.S., Moran, M.J., and Hamilton, P.A., 2001, MTBE and other volatile organic compoundsNew findings and implications on the quality of source waters used for drinking-water supplies: U.S. Geological Survey Fact Sheet 105-01, 2 p., https://pubs.usgs.gov/fs/fs10501/pdf/fs10501.pdf.

Zogorski, J.S., Carter, J.M., Ivahnenko, Tamara, Lapham, W.W., Moran, M.J., Rowe, B.L., Squillace, P.J., and Toccalino, P.L., 2006, The quality of our Nation's waters-Volatile organic compounds in the Nation's ground water and drinking-water supply wells: U.S. Geological Survey Circular 1292, 101 p., https://pubs.usgs.gov/circ/circ1292/. 


\section{Appendix 1. Attribution of Potential Explanatory Factors}

\section{Aquifer Lithology}

Aquifer lithology at the depth of the screened or open interval of each well was classified on the basis of lithologic information from California Department of Water Resources (CDWR) well-completion reports (WCRs) and from the California state geologic map (Jennings, 1977; Saucedo and others, 2000). The California state geologic map shows the lithologic unit exposed at the surface, which is not necessarily the same as the lithologic unit at the depth range in which the well is perforated or open. If the lithologic category estimated from the geologic map disagreed with the lithology described in the CDWR WCR, the categories from the CDWR WCR were used. When the CDWR WCR indicated more than one type of lithology was intersected by the screened or open interval we assigned the predominate category based on longest proportion of the screened or open interval. For the purposes of the BEAR study, the geologic units were grouped into three lithological categories:

- Granitic rocks: Mesozoic granitic rocks (California state geologic map unit grMz).

- Metamorphic rocks: Paleozoic marine rocks and consolidated metasediment and undifferentiated Precambrian rocks (California state geologic map units $\mathrm{Pz}, \mathrm{C}, \mathrm{pC}, \mathrm{pCc})$.

- Sedimentary deposits: Includes Quaternary rocks and unconsolidated material, such as alluvium and fan deposits (California state geologic map unit Q).

- The lithological categories and geologic units assigned to each U.S. Geological Survey (USGS) grid and understanding site are listed in appendix table 1-1.

\section{Land Use}

Land use was classified by using an enhanced version of the satellite imagery-derived, nationwide USGS National Land Cover Dataset (NLCD; LaMotte, 2008). The dataset characterizes land use during the early 2000s. One pixel in the dataset imagery represents a land area of 900 square-meters $\left(\mathrm{m}^{2}\right)$, calculated from the pixel resolution of 30 meters $(\mathrm{m})$. The imagery was classified into 25 land-cover classifications (Nakagaki and Wolock, 2005). These 25 land-cover catergories were aggregated into 3 principal land-uses - urban, agricultural, and natural.

Percentages of the three land-use classes for the study unit and study areas overall, for buffer areas within a radius of $500 \mathrm{~m}$ (500-m buffers) of each USGS-sampled grid and understanding site, and for areas in 500-m buffers of each California State Water Resources Control Board (SWRCB) Division of Drinking Water (SWRCB-DDW) site were calculated using a geographic information system (GIS), ESRI $^{\circledR}$ ArcGIS (Johnson and Belitz, 2009). Percentages of principal land-use classes in the $500-\mathrm{m}$ buffers around each USGS-sampled groundwater site are given in appendix table 1-1. A 500-m buffer surrounding a sampling site can be representative for the purpose of statistical assessment of relations between water quality and land uses, such as urban land use, which has been correlated to detections of VOCs (Johnson and Belitz, 2009).

\section{Septic Tank and Leaking (or Formerly Leaking) Underground Fuel-Tank Density}

Septic tank density was determined from the 1990 Census of Population and Housing (U.S. Department of Commerce, 1992). The mean density of septic tanks in each enumeration block of the housing census was calculated from the censusreported number of tanks and block area. The density of septic tanks around each USGS grid and understanding site was then calculated from the area-weighted mean of the block densities of all enumeration blocks intersecting a 500-m buffer around the site (Tyler Johnson, U.S. Geological Survey, written commun., 2013; appendix table 1-1).

Leaking (or formerly leaking) underground fuel-tank (LUFT) density was determined by the locations of tanks in the California State Water Resources Control Board's GeoTracker database of environmental-cleanup sites (California State Water Resources Control Board, 2012). The initial part of the locational search in the GeoTracker database involved limiting the data to the LUFTs. The density of LUFTs was then calculated using Theissen polygons (Thiessen, 1911; Tyler Johnson, U.S. Geological Survey, written commun., 2007). The boundaries of the Theissen polygon around a particular LUFT were established by bisecting the linear distances between the LUFT and all the surrounding LUFTs; the procedure was implemented using the geographic information system (GIS), ESRI ${ }^{\circledR}$ ArcGIS software. The density of LUFTs in the polygon is the number of tanks in the polygon (generally one) divided by the area of the polygon in square kilometers. Each USGS grid and understanding site was assigned the LUFT density of all polygons that intersected the 500-m buffer (appendix table 1-1). 
Table 1-1. Site-specific data for 2001 land use, septic tank density, leaking (or formerly leaking) underground fuel-tank (LUFT) density, and aquifer-lithology class for U.S. Geological Survey (USGS) groundwater sites in the Bear Valley and Lake Arrowhead Watershed study unit, 2010, California Groundwater Ambient Monitoring and Assessment (GAMA) Priority Basin Project.

[USGS-GAMA site identification numbers: BEAR-G, Lake Arrowhead Watershed study area grid site; BEAR-S, Bear Valley study area grid site; BEAR-U, Bear Valley and Lake Arrowhead Watershed study unit understanding site. Geologic units: C, Carboniferous marine rocks; grMz, Mesozoic granitic rocks; pC, Precambrian rocks, undivided; Pz, Paleozoic marine rocks; Q, Quaternary alluvium and fan deposits. Aquifer lithology class: G, granitic rocks; M, metamorphic rocks; S, sedimentary deposits. Abbreviations: $\mathrm{km}^{2}$, square kilometer; map, California state geologic map (see footnote 4); tanks $/ \mathrm{km}^{2}$, tanks per square kilometer; WCR, well completion report]

\begin{tabular}{|c|c|c|c|c|c|c|c|c|c|}
\hline \multirow{2}{*}{$\begin{array}{l}\text { USGS-GAMA } \\
\text { site } \\
\text { identification } \\
\text { number }\end{array}$} & \multicolumn{4}{|c|}{ Land-use information $^{1}$} & \multirow[b]{2}{*}{$\begin{array}{c}\text { Septic tank } \\
\text { density } \\
\left(\operatorname{tanks} / \mathbf{k m}^{2}\right)\end{array}$} & \multirow[b]{2}{*}{$\begin{array}{c}\text { LUFT } \\
\text { density } \\
\text { (tanks/km²) }\end{array}$} & \multicolumn{3}{|c|}{ Aquifer lithology information ${ }^{5}$} \\
\hline & $\begin{array}{c}\text { Agricultural } \\
\text { (percent) }\end{array}$ & $\begin{array}{c}\text { Natural } \\
\text { (percent) }\end{array}$ & $\begin{array}{c}\text { Urban } \\
\text { (percent) }\end{array}$ & Classification $^{2}$ & & & $\begin{array}{c}\text { Geologic } \\
\text { unit }\end{array}$ & $\begin{array}{c}\text { Aquifer } \\
\text { lithology } \\
\text { classification }\end{array}$ & $\begin{array}{c}\text { Source of } \\
\text { data }\end{array}$ \\
\hline \multicolumn{10}{|c|}{ Bear Valley study area sites } \\
\hline BEAR-S01 & 0 & 27 & 73 & Urban & 0 & 0.29 & Q & S & WCR \\
\hline BEAR-S02 & 0 & 12 & 88 & Urban & 0.02 & 2.0 & Q & S & WCR \\
\hline BEAR-S03 & 0 & 6.6 & 93 & Urban & 1.0 & 0.10 & $\mathrm{Q}$ & S & WCR \\
\hline BEAR-S04 & 0 & 44 & 56 & Urban & 3.1 & 0.10 & Q & $\mathrm{S}$ & WCR \\
\hline BEAR-S05 & 0 & 6.2 & 94 & Urban & 0.47 & 0.29 & Q & S & WCR \\
\hline BEAR-S06 & 0 & 4.5 & 96 & Urban & 0.78 & 0 & Q & S & WCR \\
\hline BEAR-S07 & 0 & 22 & 78 & Urban & 0 & 0.12 & Q & S & WCR \\
\hline BEAR-S08 & 0 & 19 & 81 & Urban & 1.6 & 0 & Q & S & WCR \\
\hline BEAR-S09 & 1.3 & 42 & 57 & Urban & 1.8 & 0 & $\mathrm{Q}^{6}$ & $\mathrm{~S} / \mathrm{M}$ & WCR \\
\hline BEAR-S10 & 0 & 83 & 17 & Natural & 2.1 & 0 & $\mathrm{Q}^{6}$ & $\mathrm{~S} / \mathrm{M}$ & WCR \\
\hline BEAR-S11 & 0 & 13 & 87 & Urban & 2.1 & 0.18 & Q & S & WCR \\
\hline BEAR-S12 & 0 & 34 & 66 & Urban & 1.3 & 0 & Q & S & map \\
\hline BEAR-S13 & 0 & 35 & 65 & Urban & 1.2 & 0 & $\mathrm{Q}^{6}$ & $\mathrm{~S} / \mathrm{M}$ & WCR \\
\hline BEAR-S14 & 0 & 94 & 6.0 & Natural & 1.5 & 0 & $\mathrm{Pz}$ & M & map \\
\hline BEAR-U02 & 1.6 & 42 & 56 & Urban & 2.8 & 0.08 & Q & S & WCR \\
\hline BEAR-U03 & 0 & 87 & 13 & Natural & 2.1 & 0 & $\mathrm{Pz}$ & M & WCR \\
\hline BEAR-U04 & 0 & 78 & 22 & Natural & 2.1 & 0 & $\mathrm{Pz}$ & M & WCR \\
\hline BEAR-U06 & 0 & 100 & 0.1 & Natural & 0.47 & 0.12 & $\mathrm{pC}$ & M & WCR \\
\hline BEAR-U07 & 0 & 69 & 31 & Natural & 0.38 & 0.12 & $\mathrm{pC}$ & M & map \\
\hline BEAR-U08 & 0 & 8.6 & 91 & Urban & 0.04 & 0.12 & $\mathrm{C}$ & M & map \\
\hline BEAR-U09 & 0 & 15 & 85 & Urban & 0.16 & 0.12 & $\mathrm{C}$ & M & WCR \\
\hline
\end{tabular}


Table 1-1. Site-specific data for 2001 land use, septic tank density, leaking (or formerly leaking) underground fuel-tank (LUFT) density, and aquifer-lithology class for U.S. Geological Survey (USGS) groundwater sites in the Bear Valley and Lake Arrowhead Watershed study unit, 2010, California Groundwater Ambient Monitoring and Assessment (GAMA) Priority Basin Project.—Continued

[USGS-GAMA site identification numbers: BEAR-G, Lake Arrowhead Watershed study area grid site; BEAR-S, Bear Valley study area grid site; BEAR-U, Bear Valley and Lake Arrowhead Watershed study unit understanding site. Geologic units: C, Carboniferous marine rocks; grMz, Mesozoic granitic rocks; pC, Precambrian rocks, undivided; Pz, Paleozoic marine rocks; Q, Quaternary alluvium and fan deposits. Aquifer lithology class: G, granitic rocks; M, metamorphic rocks; S, sedimentary deposits. Abbreviations: $\mathrm{km}^{2}$, square kilometer; map, California state geologic map (see footnote 4); tanks $/ \mathrm{km}^{2}$, tanks per square kilometer; WCR, well completion report]

\begin{tabular}{|c|c|c|c|c|c|c|c|c|c|}
\hline \multirow{2}{*}{$\begin{array}{l}\text { USGS-GAMA } \\
\text { site } \\
\text { identification } \\
\text { number }\end{array}$} & \multicolumn{4}{|c|}{ Land-use information $^{1}$} & \multirow[b]{2}{*}{$\begin{array}{l}\text { Septic tank } \\
\text { density }^{3} \\
(\text { tanks/km²) }\end{array}$} & \multirow[b]{2}{*}{$\begin{array}{c}\text { LUFT } \\
\text { density }^{4} \\
\text { (tanks/km²) }\end{array}$} & \multicolumn{3}{|c|}{ Aquifer lithology information ${ }^{5}$} \\
\hline & $\begin{array}{l}\text { Agricultural } \\
\text { (percent) }\end{array}$ & $\begin{array}{l}\text { Natural } \\
\text { (percent) }\end{array}$ & $\begin{array}{c}\text { Urban } \\
\text { (percent) }\end{array}$ & Classification $^{2}$ & & & $\begin{array}{c}\text { Geologic } \\
\text { unit }\end{array}$ & $\begin{array}{c}\text { Aquifer } \\
\text { lithology } \\
\text { classification }\end{array}$ & $\begin{array}{c}\text { Source of } \\
\text { data }\end{array}$ \\
\hline \multicolumn{10}{|c|}{ Lake Arrowhead Watershed study area sites } \\
\hline BEAR-G01 & 0 & 10 & 90 & Urban & 0.33 & 0.01 & grMz & G & WCR \\
\hline BEAR-G02 & 0 & 72 & 28 & Natural & 2.1 & 0.03 & grMz & G & map \\
\hline BEAR-G04 & 0 & 47 & 53 & Urban & 0.37 & 0.03 & grMz & G & map \\
\hline BEAR-G05 & 0 & 84 & 16 & Natural & 0.41 & 0.03 & grMz & G & map \\
\hline BEAR-G06 & 0 & 93 & 7.0 & Natural & 2.3 & 0.40 & grMz & G & map \\
\hline BEAR-G10 & 0 & 25 & 75 & Urban & 0.54 & 0.01 & grMz & $\mathrm{G}$ & WCR \\
\hline BEAR-G11 & 0 & 61 & 39 & Natural & 23.8 & 0.40 & grMz & $\mathrm{G}$ & map \\
\hline BEAR-G12 & 0 & 76 & 24 & Natural & 0.97 & 0.01 & grMz & G & map \\
\hline BEAR-G13 & 0 & 55 & 45 & Natural & 0 & 0.03 & grMz & G & WCR \\
\hline BEAR-U01 & 0 & 45 & 55 & Urban & 2.2 & 0.11 & grMz & G & WCR \\
\hline BEAR-U05 & 0.1 & 74 & 26 & Natural & 0.80 & 0.01 & grMz & G & map \\
\hline BEAR-U10 & 0 & 34 & 66 & Urban & 0.54 & 0.01 & grMz & $\mathrm{G}$ & WCR \\
\hline
\end{tabular}

${ }^{1}$ The land-use data is from LaMotte (2008). Land-use percentages are within a 500-meter radius of each site (Johnson and Belitz, 2009).

${ }^{2} \mathrm{~A} 51$-percent threshold was used to assign a dominant category rather than the default, "mixed" category.

${ }^{3}$ The septic tank density is within a 500-meter radius of the site, based on data from the U.S. Census Bureau (1990).

${ }^{4}$ The LUFT density is within a 500-meter radius of the site, based on locations from the California State Water Resources Control Board (2012).

${ }^{5}$ Classification is based on the lithology of a perforated or open interval as described in the California Department of Water Resources WCR, if available. For wells without WCRs, lithology was inferred from a geologic map of California (Jennings, 1977; Saucedo and others, 2000). Wells can have perforated or open intervals in more than one lithology.

${ }^{6}$ The WCR showed evidence of metamorphic rock lithology at certain depths in the perforation or open interval. 


\section{Elevation}

The elevation for each USGS grid and understanding site was obtained from U.S. Geological Survey (2006)

National Elevation Dataset, which was automatically sampled and assigned groundwater site using a GIS. For this study, elevation of the intersection of the well or spring with the land surface is expressed as feet above the North American Vertical Datum of 1988 (NAVD 88; appendix table 1-2).

\section{Aridity Index}

The climate at each USGS grid and understanding site was represented by an aridity index (United Nations Educational, Scientific, and Cultural Organization, 1979; United Nations Environment Programme, 1997; appendix table 1-2):

$$
\text { aridity index }=\frac{\text { average annaul precipitation }}{\text { average annual evapotranspiration }}
$$

Greater values of the index correspond to wetter conditions. Average annual precipitation values for each USGS grid and understanding site was assigned from the PRISM grid cell coincident with the site location in the "PRISM average annual precipitation for 1971-2000" GIS coverage (PRISM Group, 2012). Average annual evapotranspiration values for each USGS grid and understanding site was assigned from the ESRI ${ }^{\circledR}$ ArcGIS coverage modified from Flint and Flint (2007). The modification consisted of calibrating the evapotranspiration values to the measured California Irrigation Management Information System reference-evapotranspiration values (California Irrigation Management Information System, 2005; Alan Flint, U.S. Geological Survey, oral commun., 2009). The aridity index can be grouped into six classes: values less than 0.05 are defined as hyper-arid, 0.05 to less than or equal to 0.20 as arid, 0.20 to less than or equal to 0.50 as semi-arid, 0.50 to less than or equal to 0.65 as dry subhumid, 0.65 to less than or equal to 1.00 as humid, and greater than 1.00 as wet (United Nations Educational, Scientific, and Cultural Organization, 1979; United Nations Environment Programme, 1997).

\section{Well Construction}

Most well-construction data were compiled by the USGS from the WCRs filed with California Department of Water Resources (CDWR). In locations where CDWR WCRs were not available, well construction data were obtained from ancillary records of site owners or the USGS National Water Information System database (http://waterdata.usgs.gov/nwis). The USGS-GAMA site-verification procedures were described by Mathany and Belitz (2013). Well depths and depths to the top and bottom of the perforated interval of the well casing for USGS grid and understanding sites are listed in appendix table 1-2. Sites were classified as springs if water could flow from the aquifer into the distribution system without a pump or if the site either was drilled horizontally or had no borehole. The springs were assigned a value of "at LSD" (at land-surface datum) for the well depth, equivalent to $0 \mathrm{ft}$ below land surface, and the "not available" code was used for the associated depths to the top and bottom of the perforated interval.

\section{Groundwater-Age Classification}

Groundwater dating techniques indicate the time since the groundwater was recharged to the primary aquifer system. The techniques used in this report to estimate groundwater residence times or 'age' were based on tritium (Tolstikhin and Kamenskiy, 1969; Torgersen and others, 1979) and carbon-14 activities (Vogel and Ehhalt, 1963; Plummer and others, 1993).

Tritium is a short-lived radioactive isotope of hydrogen with a half-life of 12.32 years (Lucas and Unterweger, 2000). Tritium is produced naturally in the atmosphere from the interaction of cosmogenic radiation with nitrogen (Craig and Lal, 1961) and anthropogenically by aboveground nuclear explosions and the waste produced by the operation of nuclear reactors. Tritium enters the hydrological cycle following oxidation to tritiated water. Aboveground nuclear explosions resulted in a large increase of tritium in precipitation beginning in about 1952 and peaking in 1963 at values exceeding 1,000 tritium units (TU) in the northern hemisphere (Michel, 1989). Radioactive decay over 50 years would decrease an initial tritium value of $10 \mathrm{TU}$ to an ending value of 0.6 TU. Tritium values in 2010 precipitation under natural conditions in the BEAR study unit would likely be about 2 to 5 TU (Robert Michel, U.S. Geological Survey, Menlo Park Stable Isotope and Tritium Labs, written commun., 2013).

Previous investigations have used a range of tritium values from 0.3 to $2.0 \mathrm{TU}$ as thresholds for indicating presence of water that has exchanged with the atmosphere since 1952 (Michel, 1989; Plummer and others, 1993; Michel and Schroeder, 1994; Clark and Fritz, 1997; Manning and others, 2005). For USGS grid and understanding samples collected for the BEAR study unit in 2010 (Mathany and Belitz, 2013), tritium values greater than a threshold of $2.0 \mathrm{TU}$ were inferred to indicate the presence of groundwater recharged after 1952. 
Table 1-2. Well and construction information and hydrologic conditions for U.S. Geological Survey (USGS) grid and understanding sites in the Bear Valley and Lake Arrowhead Watershed study unit, California Groundwater Ambient Monitoring and Assessment (GAMA) Priority Basin Project.

[USGS-GAMA site identification numbers: BEAR-G, Lake Arrowhead Watershed study area grid site; BEAR-S, Bear Valley study area grid site; BEAR-U, Bear Valley and Lake Arrowhead Watershed study unit understanding site. Abbreviations: ft bls, feet below land surface; LSD, land-surface datum; na, not available]

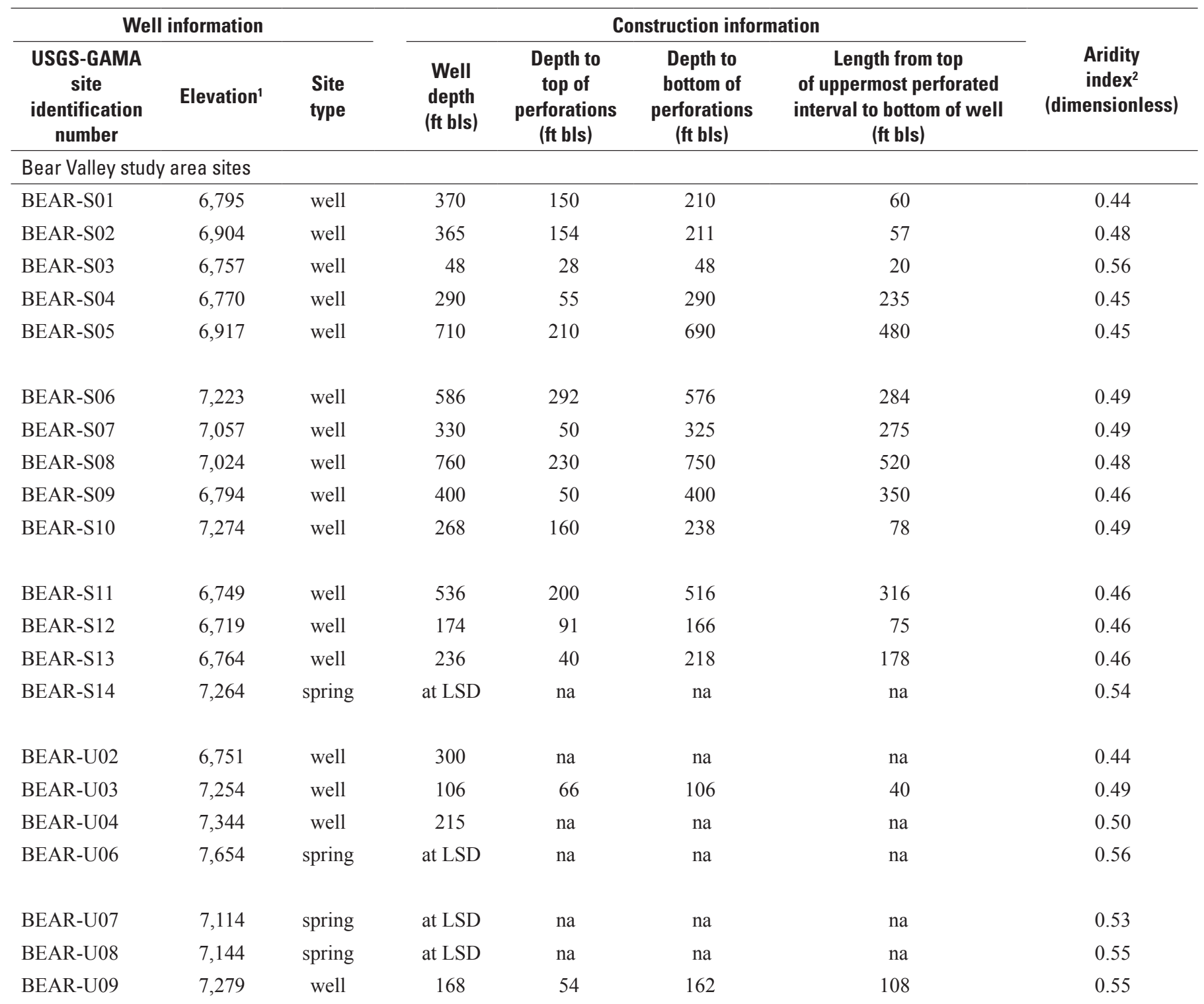


Table 1-2. Well and construction information and hydrologic conditions for U.S. Geological Survey (USGS) grid and understanding sites in the Bear Valley and Lake Arrowhead Watershed study unit, California Groundwater Ambient Monitoring and Assessment (GAMA) Priority Basin Project.-Continued

[USGS-GAMA site identification numbers: BEAR-G, Lake Arrowhead Watershed study area grid site; BEAR-S, Bear Valley study area grid site; BEAR-U, Bear Valley and Lake Arrowhead Watershed study unit understanding site. Abbreviations: ft bls, feet below land surface; LSD, land-surface datum; na, not available]

\begin{tabular}{|c|c|c|c|c|c|c|c|}
\hline \multicolumn{3}{|c|}{ Well information } & \multicolumn{4}{|c|}{ Construction information } & \multirow[b]{2}{*}{$\begin{array}{c}\text { Aridity } \\
\text { index } \\
\text { (dimensionless) }\end{array}$} \\
\hline $\begin{array}{l}\text { USGS-GAMA } \\
\text { site } \\
\text { identification } \\
\text { number }\end{array}$ & Elevation ${ }^{1}$ & $\begin{array}{l}\text { Site } \\
\text { type }\end{array}$ & $\begin{array}{l}\text { Well } \\
\text { depth } \\
\text { (ft bls) }\end{array}$ & $\begin{array}{c}\text { Depth to } \\
\text { top of } \\
\text { perforations } \\
\text { (ft bls) }\end{array}$ & $\begin{array}{c}\text { Depth to } \\
\text { bottom of } \\
\text { perforations } \\
\text { (ft bls) }\end{array}$ & $\begin{array}{c}\text { Length from top } \\
\text { of uppermost perforated } \\
\text { interval to bottom of well } \\
\text { (ft bls) }\end{array}$ & \\
\hline \multicolumn{8}{|c|}{ Lake Arrowhead Watershed study area sites } \\
\hline BEAR-G01 & 6,403 & well & 230 & na & na & na & 0.66 \\
\hline BEAR-G03 & 4,753 & well & 300 & na & na & na & 0.67 \\
\hline BEAR-G04 & 5,343 & spring & at LSD & na & na & na & 0.61 \\
\hline BEAR-G05 & 5,443 & spring & at LSD & na & na & na & 0.64 \\
\hline BEAR-G09 & 4,723 & well & 500 & na & na & na & 0.46 \\
\hline BEAR-G10 & 6,944 & well & 220 & na & na & na & 0.64 \\
\hline BEAR-G11 & 4,763 & spring & at LSD & na & na & na & 0.68 \\
\hline BEAR-G12 & 6,113 & spring & at LSD & na & na & na & 0.58 \\
\hline BEAR-G13 & 5,288 & well & 375 & na & na & na & 0.55 \\
\hline BEAR-U01 & 6,203 & well & 380 & 200 & 380 & 180 & 0.71 \\
\hline BEAR-U05 & 7,104 & spring & at LSD & na & na & na & 0.65 \\
\hline
\end{tabular}

${ }^{1}$ Site elevation is given as the altitude of its land-surface datum (LSD). Each LSD is a datum plane that is approximately at land surface at the site. The altitude of the LSD is described in feet above the North American Vertical Datum 1988.

${ }^{2}$ Aridity index is average annual precipitation (PRISM Group, 2012) divided by average annual evapotranspiration (Flint and Flint, 2007). 
Carbon-14 $\left({ }^{14} \mathrm{C}\right)$ is a widely used chronometer based on the radiocarbon content of organic and inorganic carbon. Dissolved inorganic carbon species, carbonic acid, bicarbonate, and carbonate typically are used for ${ }^{14} \mathrm{C}$ dating of groundwater. Carbon-14 is formed in the atmosphere by the interaction of cosmic-ray neutrons with nitrogen atoms and, to a lesser degree, with oxygen and carbon. Carbon-14 is incorporated into carbon dioxide and mixed throughout the atmosphere. Carbon dioxide enters the hydrologic cycle because it dissolves in precipitation and surface water in contact with the atmosphere. Carbon-14 activity in groundwater, expressed as percent modern carbon (pmc), reflects the time since groundwater was last exposed to the atmospheric ${ }^{14} \mathrm{C}$ source. ${ }^{14} \mathrm{C}$ has a half-life of 5,730 years and can be used to estimate groundwater ages ranging from 1,000 to approximately 30,000 years before present.

The ${ }^{14} \mathrm{C}$ age (residence time in the aquifer, presented in years) is calculated on the basis of the decrease in ${ }^{14} \mathrm{C}$ activity as a result of radioactive decay since groundwater recharge, relative to an assumed initial ${ }^{14} \mathrm{C}$ concentration (Clark and Fritz, 1997). An average initial ${ }^{14} \mathrm{C}$ activity of $100 \mathrm{pmc}$ is assumed for this study, with estimated errors on calculated groundwater ages up to plus or minus 20 percent. Calculated ${ }^{14} \mathrm{C}$ ages in this study are referred to as "uncorrected" because they have not been adjusted to consider exchanges with sedimentary sources of carbon (Fontes and Garnier, 1979). Groundwater with a ${ }^{14} \mathrm{C}$ activity of greater than $88 \mathrm{pmc}$ is reported as having an age of less than 1,000 years; no attempt was made to refine ${ }^{14} \mathrm{C}$ ages of less than 1,000 years. Measured values of pmc can be greater than 100 pmc because the definition of the ${ }^{14} \mathrm{C}$ activity in modern carbon does not include the excess ${ }^{14} \mathrm{C}$ produced in the atmosphere by aboveground nuclear weapons testing. For the BEAR study unit, ${ }^{14} \mathrm{C}$ activity less than $88 \mathrm{pmc}$ was defined as indicative of presence of groundwater recharged before the modern era.

In this study, the age distributions of samples are classified as modern, mixed, and pre-modern (or a combination of the three). Groundwater with tritium activities greater than $2.0 \mathrm{TU}$ and ${ }^{14} \mathrm{C}$ greater than $88 \mathrm{pmc}$ is designated as modern, defined as having been recharged after 1952. Groundwater with tritium activity less than $0.3 \mathrm{TU}$ and ${ }^{14} \mathrm{C}$ less than $88 \mathrm{pmc}$ is designated as pre-modern, defined as having been recharged before 1952. Samples with premodern and modern components are designated as mixedage groundwater, which includes substantial fractions of old and young waters. Samples with tritium activity greater than $2.0 \mathrm{TU}$ but no carbon-14 data were classified as modern. Samples with tritium activity less than $0.3 \mathrm{TU}$ but no carbon-14 data were classified as pre-modern. In reality, pre-modern groundwater could contain very small fractions of modern groundwater, and modern groundwater could contain small fractions of pre-modern groundwater. Tritium activities, percent modern carbon, uncorrected ${ }^{14} \mathrm{C}$ age, and sample age class for USGS grid and understanding sites are reported in appendix table 1-3. Although more sophisticated lumped parameter models used for analyzing age distributions that incorporate mixing are available (for example, Cook and Böhlke, 2000), use of these alternative models to characterize age mixtures was beyond the scope of this report. Rather, classification into modern (recharged after 1952), mixed, and pre-modern (recharged before 1952) age was sufficient to provide an appropriate and useful characterization for the purposes of examining groundwater quality.

\section{Oxidation-Reduction Condition, Dissolved Oxygen Concentration, and pH}

Geochemical conditions investigated as potential explanatory variables in this report include oxidationreduction (redox) characteristics, dissolved oxygen (DO) concentrations, and $\mathrm{pH}$ (appendix table 1-4). Redox conditions influence the mobility of many organic and inorganic constituents (McMahon and Chapelle, 2008). Along groundwater flow paths, redox conditions commonly proceed along a well-documented sequence of terminal electronacceptor processes (TEAP); one TEAP typically dominates at a particular time and aquifer location (Chapelle and others, 1995; Chapelle, 2001). The predominant TEAPs (in order of least to most reducing) are oxygen reduction, nitrate reduction, manganese reduction, iron reduction, sulfate reduction, and carbon-dioxide reduction. The presence of redox-sensitive chemical species representing more than one TEAP could indicate mixed waters from different redox zones upgradient of the site, a well perforated in more than one redox zone, or spatially heterogeneous microbial activity in the aquifer. Different redox elements (iron, manganese, and sulfur) tend not to reach complete equilibrium in most natural water systems (Lindberg and Runnels, 1984); therefore, a single redox measurement usually cannot represent the system, further complicating the assessment of redox conditions. The $\mathrm{pH}$ value is the measure of hydrogen-ion activity in a water sample and is sensitive to a number of geochemical reactions in addition to redox conditions. An automated workbook program was used to assign the redox classification to each USGS grid and understanding sample (Jurgens and others, 2009) on the basis of DO, nitrate, manganese, and iron concentrations using the classification scheme of McMahon and Chapelle (2008). 
Table 1-3. Groundwater-age class and the associated data for samples from U.S. Geological Survey (USGS) grid and understanding sites in the Bear Valley and Lake Arrowhead Watershed study unit, 2010, California Groundwater Ambient Monitoring and Assessment (GAMA) Priority Basin Project.

[Groundwater-age classification: Mixed-age, groundwater containing components recharged before and after 1952 (greater than 0.3 TU and less than or equal to 2.0 TU); Modern, groundwater recharged since 1952 (greater than 2.0 TU); Pre-modern, groundwater recharged before 1952 (less than or equal to 0.3 TU). USGS-GAMA site identification numbers: BEAR-G, Lake Arrowhead Watershed grid site; BEAR-S, Bear Valley study area grid site; BEAR-U, Bear Valley and Lake Arrowhead Watershed study unit understanding site. Abbreviations: ${ }^{14} \mathrm{C}$, carbon-14; LSD, land-surface datum; na, not available; TU, tritium units; $<$, less than]

\begin{tabular}{|c|c|c|c|c|c|}
\hline $\begin{array}{l}\text { USGS-GAMA } \\
\text { site } \\
\text { identification } \\
\text { number }\end{array}$ & $\begin{array}{l}\text { Groundwater- } \\
\text { age } \\
\text { classification }\end{array}$ & $\begin{array}{c}\text { Tritium } \\
\text { (TU) }\end{array}$ & $\begin{array}{c}\text { Percent } \\
\text { modern } \\
\text { carbon }\end{array}$ & $\begin{array}{l}\text { Uncorrected } \\
{ }^{14} \mathrm{C} \text { age } \\
\text { (years) }\end{array}$ & $\begin{array}{l}\text { Site } \\
\text { type }\end{array}$ \\
\hline \multicolumn{6}{|c|}{ Bear Valley study area sites } \\
\hline BEAR-S01 & Mixed-age & 1.7 & 80 & 1,690 & Well \\
\hline BEAR-S02 & Mixed-age & 0.7 & 78 & 1,930 & Well \\
\hline BEAR-S03 & Modern & 2.8 & 104 & $<1,000$ & Well \\
\hline BEAR-S04 & Pre-modern & 0.3 & 6.0 & 22,910 & Well \\
\hline BEAR-S05 & Pre-modern & $<0.1$ & 38 & 7,690 & Well \\
\hline BEAR-S06 & Pre-modern & 0.2 & 77 & 2,040 & Well \\
\hline BEAR-S07 & Modern & 2.3 & 97 & $<1,000$ & Well \\
\hline BEAR-S08 & Pre-modern & 0.1 & 71 & 2,640 & Well \\
\hline BEAR-S09 & Mixed-age & 0.5 & 84 & 1,310 & Well \\
\hline BEAR-S10 & Mixed-age & 0.9 & $\mathrm{na}^{1}$ & $\mathrm{na}^{1}$ & Well \\
\hline BEAR-S11 & Mixed-age & 1.1 & $\mathrm{na}^{1}$ & $\mathrm{na}^{1}$ & Well \\
\hline BEAR-S12 & Pre-modern & 0.1 & 70 & 2,790 & Well \\
\hline BEAR-S13 & Mixed-age & 0.5 & 76 & 2,160 & Well \\
\hline BEAR-S14 & Modern & 2.8 & $\mathrm{na}^{1}$ & $\mathrm{na}^{1}$ & Spring \\
\hline BEAR-U02 & Mixed-age & 1.0 & 85 & 1,220 & Well \\
\hline BEAR-U03 & Modern & 2.3 & 99 & $<1,000$ & Well \\
\hline BEAR-U04 & Pre-modern & 0.2 & $\mathrm{na}^{1}$ & $\mathrm{na}^{1}$ & Well \\
\hline BEAR-U06 & Modern & 4.3 & 108 & $<1,000$ & Spring \\
\hline BEAR-U07 & Modern & 3.3 & 104 & $<1,000$ & Spring \\
\hline BEAR-U08 & Pre-modern & 0.1 & 53 & 4,980 & Spring \\
\hline BEAR-U09 & Modern & 3.3 & 92 & $<1,000$ & Well \\
\hline
\end{tabular}

\begin{tabular}{|c|c|c|c|c|c|}
\hline $\begin{array}{c}\text { USGS-GAMA } \\
\text { site } \\
\text { identification } \\
\text { number }\end{array}$ & $\begin{array}{l}\text { Groundwater- } \\
\text { age } \\
\text { classification }\end{array}$ & $\begin{array}{c}\text { Tritium } \\
\text { (TU) }\end{array}$ & $\begin{array}{c}\text { Percent } \\
\text { modern } \\
\text { carbon }\end{array}$ & $\begin{array}{l}\text { Uncorrected } \\
{ }^{14} \mathrm{C} \text { age } \\
\text { (years) }\end{array}$ & $\begin{array}{l}\text { Site } \\
\text { type }\end{array}$ \\
\hline \multicolumn{6}{|c|}{ Lake Arrowhead Watershed study area sites } \\
\hline BEAR-G01 & Mixed-age & 1.7 & 78 & 1,950 & Well \\
\hline BEAR-G02 & Modern & 3.1 & 109 & $<1,000$ & Spring \\
\hline BEAR-G03 & Modern & 4.4 & 107 & $<1,000$ & Well \\
\hline BEAR-G04 & Mixed-age & 1.9 & 100 & $<1,000$ & Spring \\
\hline BEAR-G05 & Mixed-age & 1.9 & 88 & $<1,000$ & Spring \\
\hline BEAR-G06 & Mixed-age & 1.0 & 90 & $<1,000$ & Spring \\
\hline BEAR-G07 & Mixed-age & 1.3 & 79 & 1,810 & Well \\
\hline BEAR-G08 & Mixed-age & 1.1 & $\mathrm{na}^{1}$ & $\mathrm{na}^{1}$ & Well \\
\hline BEAR-G09 & Mixed-age & 0.9 & 73 & 2,490 & Well \\
\hline BEAR-G10 & Modern & 2.0 & 82 & 1,580 & Well \\
\hline BEAR-G11 & Modern & 2.6 & 101 & $<1,000$ & Spring \\
\hline BEAR-G12 & Modern & 2.5 & $\mathrm{na}^{1}$ & $\mathrm{na}^{1}$ & Spring \\
\hline BEAR-G13 & Mixed-age & 1.4 & 96 & $<1,000$ & Well \\
\hline BEAR-U01 & Mixed-age & 1.9 & $\mathrm{na}^{1}$ & $\mathrm{na}^{1}$ & Well \\
\hline BEAR-U05 & Modern & 3.6 & $\mathrm{na}^{1}$ & $\mathrm{na}^{1}$ & Spring \\
\hline BEAR-U10 & Modern & 2.9 & 110 & $<1,000$ & Spring \\
\hline BEAR-U11 & Pre-modern & 0.3 & 68 & 2,980 & Well \\
\hline
\end{tabular}

${ }^{1}$ The sample was broken during shipment to the laboratory. 
Table 1-4. Oxidation-reduction class, dissolved oxygen concentration, and pH of samples from U.S. Geological Survey (USGS) grid and understanding sites in the Bear Valley and Lake Arrowhead Watershed study unit, 2010, California Groundwater Ambient Monitoring and Assessment (GAMA) Priority Basin Project.

[Oxidation-reduction classification based on Jurgens and others (2009): Fe-red, iron-reducing; MnFe-red, manganese- and iron-reducing; Mn-red, manganese-reducing. USGS-GAMA site identification numbers: BEAR-G, Lake Arrowhead Watershed study area grid site; BEAR-S, Bear Valley study area grid site; BEAR-U, Bear Valley and Lake Arrowhead Watershed study unit understanding site. Abbreviations: mg/L, milligrams per liter]

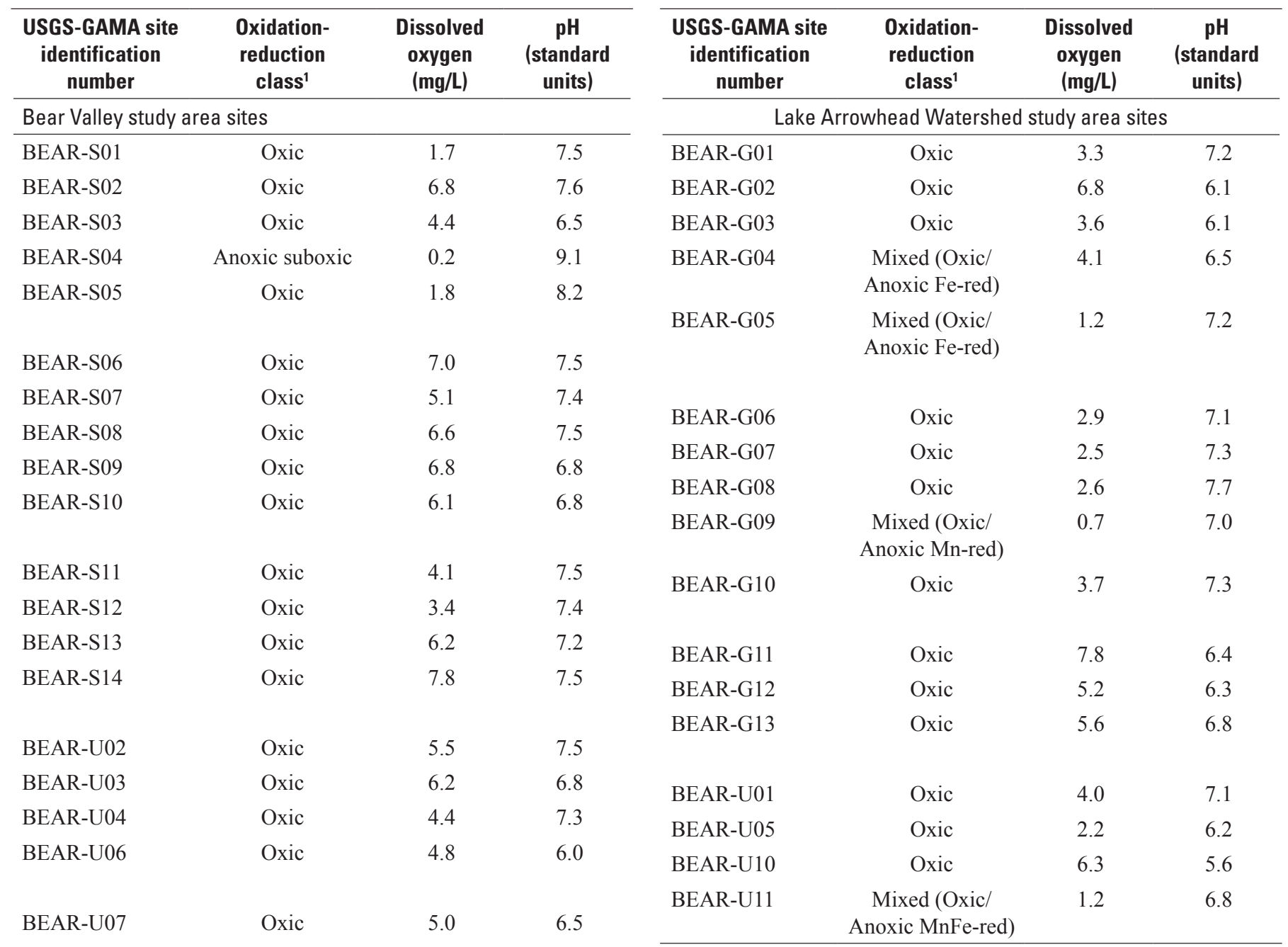

$\begin{array}{cccc}\text { BEAR-U08 } & \begin{array}{c}\text { Mixed (Oxic/ } \\ \text { Anoxic MnFe-red) }\end{array} & 5.1 & 7.7 \\ \text { BEAR-U09 } & \text { Oxic } & 2.2 & 7.1\end{array}$

${ }^{1}$ Data from Mathany and Belitz (2013) were used for the classification, in addition to the dissolved oxygen and $\mathrm{pH}$ data presented in this table. 


\section{References Cited}

California Irrigation Management Information System, 2005, CIMIS reference evapotranspiration zones, accessed April 16, 2009, at http://wwwcimis.water.ca.gov/App_ Themes/images/etozonemap.jpg.

California State Water Resources Control Board, 2012, Geographic Environmental Information Management System GeoTracker (GEIMS) Leaking Underground Fuel/Storage Tank database (LUFT): Sacramento, Calif., California Environmental Protection Agency, State Water Resources Control Board, Division of Water Quality digital data, accessed November 28, 2012, at http://geotracker. waterboards.ca.gov/search.asp?CMD=search\&case number $=\&$ business_name $=\&$ main_street name $=\&$ city $=\& z i p=\&$ county $=\&$ SITE $\_$TYPE $=$LUFT $\&$ STA TUS $=\& B R A N C H=\& M A S T E R \_B A S E=\&$ Search $=$ Search.

Chapelle, F.H., 2001, Groundwater microbiology and geochemistry $(2 \mathrm{~d}$ ed.): New York, N.Y., John Wiley and Sons, Inc., 477 p.

Chapelle, F.H., McMahon, P.B., Dubrovsky, N.M., Fuji, R.F., Oaksford, E.T., and Vroblesky, D.A., 1995, Deducing the distribution of terminal electron-accepting processes in hydrologically diverse groundwater systems: Water Resources Research, v. 31, no. 2, p. 359-371, http://onlinelibrary.wiley.com/doi/10.1029/94WR02525/pdf.

Clark, I.D., and Fritz, Peter, 1997, Environmental isotopes in hydrogeology: New York, N.Y., Lewis Publishers, 328 p.

Cook, P.G., and Böhlke, J.K., 2000, Determining timescales for groundwater flow and solute transport, in Cook, P.G., and Herczeg, A., eds., Environmental tracers in subsurface hydrology: Boston, Kluwer Academic Publishers, p. 1-30.

Craig, Harmon, and Lal, Devendra, 1961, The production rate of natural tritium: Tellus, v. 13, p. 85-105.

Flint, L.E., and Flint, A.L., 2007, Regional analysis of ground-water recharge: U.S. Geological Survey Professional Paper 1703-B, p. 29-60, https://pubs.usgs.gov/pp/pp1703/b/.

Fontes, J.C., and Garnier, J.-M., 1979, Determination of the initial ${ }^{14} \mathrm{C}$ activity of the total dissolved carbon- $\mathrm{A}$ review of the existing models and a new approach: Water Resources Research, v. 15, no. 2, p. 399-413, http://onlinelibrary.wiley.com/doi/10.1029/ WR015i002p00399/epdf.

Jennings, C.W., 1977, Geologic map of California: California Department of Conservation, Division of Mines and Geology Geologic Data Map No. 2, scale 1:750,000.
Johnson, T.D., and Belitz, Kenneth, 2009, Assigning land use to supply wells for the statistical characterization of regional groundwater quality - Correlating urban land use and VOC occurrence: Journal of Hydrology, v. 370, no. 1-4, p. 100-108, http://www.sciencedirect.com/science/article/ pii/S0022169409001462.

Jurgens, B.C., McMahon, P.B., Chapelle, F.H., and Eberts, S.M., 2009, An Excel ${ }^{\mathbb{R}}$ workbook for identifying redox processes in ground water: U.S. Geological Survey Open-File Report 2009-1004, 8 p., https://pubs.usgs.gov/of/2009/1004/.

LaMotte, Andrew, 2008, National Land Cover Database 2001 (NLCD01) Tile 3, southwest United States, NLCD01_3: U.S. Geological Survey Raster digital data, accessed June 12, 2015, at http://water.usgs.gov/GIS/metadata/ usgswrd/XML/nlcd01_3.xml.

Lindberg, R.D., and Runnells, D.D., 1984, Groundwater redox reactions: Science, v. 225, p. 925-927.

Lucas, L.L., and Unterweger, M.P., 2000, Comprehensive review and critical evaluation of the half-life of tritium: Journal of Research of the National Institute of Standards and Technology, v. 105, no. 4, p. 541-549, http://nvlpubs.nist.gov/nistpubs/jres/105/4/j54luc2.pdf.

Manning, A.H., Solomon, D.K., and Thiros, S.A., 2005, ${ }^{3} \mathrm{H} /{ }^{3} \mathrm{He}$ age data in assessing the susceptibility of wells to contamination: Groundwater, v. 43, no. 3, p. 353-367, http://onlinelibrary.wiley.com/doi/10.1111/j.17456584.2005.0028.x/full.

McMahon, P.B., and Chapelle, F.H., 2008, Redox processes and water quality of selected principal aquifer systems: Groundwater, v. 46, no. 2, p. 259-271, http://onlinelibrary. wiley.com/doi/10.1111/j.1745-6584.2007.00385.x/full.

Michel, R.L., 1989, Tritium deposition in the continental United States, 1953-1983: U.S. Geological Survey Water-Resources Investigations Report 89-4072, 46 p., https://pubs.er.usgs.gov/publication/wri894072.

Michel, R.L., and Schroeder, R.A., 1994, Use of longterm tritium records from the Colorado River to determine timescales for hydrologic processes associated with irrigation in the Imperial Valley, California: Applied Geochemistry, v. 9, no. 4, p. 387-401, https://doi.org/10.1016/0883-2927(94)90061-2.

Nakagaki, Naomi, and Wolock, D.M., 2005, Estimation of agricultural pesticide use in drainage basins using land cover maps and county pesticide data: U.S. Geological Survey Open-File Report 2005-1188, 56 p., https://pubs.usgs.gov/of/2005/1188/. 
Plummer, L.N., Michel, R.L., Thurman, E.M., and Glynn, P.D., 1993, Environmental tracers for age-dating young ground water, in Alley, W.M. ed., Regional groundwater quality: New York, N.Y., Van Nostrand Reinhold, p. 255-294.

PRISM Group, 2012, United States average annual precipitation, maximum and minimum temperature, 19712000: Oregon State University, PRISM website, accessed August 9, 2012, at http://prism.oregonstate.edu/.

Saucedo, G.J., Bedford, D.R., Raines, G.L., Miller, R.J., and Wentworth, C.M., 2000, GIS data for the geologic map of California: California Department of Conservation, Division of Mines and Geology, CD-ROM 2000-007.

Thiessen, A.H., 1911, Precipitation for large areas: Monthly Weather Review, v. 39, p. 1082-1084.

Tolstikhin, I.N., and Kamenskiy, I.L., 1969, Determination of groundwater ages by the T-3He method: Geochemistry International, v. 6, p. 310-811.

Torgersen, Thomas., Clarke, W.B., and Jenkins, W.J., 1979, The tritium/helium-3 method in hydrology, in Isotope Hydrology 1978: Vienna, Austria, International Atomic Energy Agency (IAEA), no. IAEA-SM-228/2, p. 917-930.

United Nations Educational, Scientific, and Cultural Organization (UNESCO), 1979, Map of the world distribution of arid regions-Explanatory note: MAB Technical Notes, v. 7, 54 p., http://unesdoc.unesco.org/ images/0003/000326/032661eo.pdf.

United Nations Environment Programme, 1997, World Atlas of Desertification ( $2 \mathrm{~d}$ ed.): London, Edward Arnold, 182 p.

U.S. Department of Commerce, 1992, 1990 Census of population and housing, summary tape file $3 \mathrm{~A}$ : U. S. Census Bureau, CD-ROM, http://www.census.gov/mp/www/cat/ decennial_census_1990/1990_census_of_population_and housing_summary_tape_file_3a.html.

U.S. Geological Survey, 2006, National Elevation Dataset (NED): U.S. Geological Survey database, accessed March 10, 2017, at http://ned.usgs.gov.

Vogel, J.C., and Ehhalt, D.H., 1963, The use of the carbon isotopes in groundwater studies - Radioisotopes in hydrology: Vienna, Austria, International Atomic Energy Agency (IAEA), p. 383-395. 


\section{Appendix 2. Additional Water-Quality Data}

Appendix table 2-1 presents the data determined at Lawrence Livermore National Laboratory for dissolved noble gases (argon, helium-4, krypton, neon, and xenon) and heliumisotope ratios. These results were not completed in time for inclusion in the USGS Data Series Report No. 747 for the BEAR study unit (Mathany and Belitz, 2013) and are included in this report for completeness.

Table 2-1. Analytical results from the Lawrence Livermore National Laboratory (LLNL) for dissolved noble gases and helium isotope ratios in groundwater samples collected by U.S. Geological Survey (USGS) for the Bear Valley and Lake Arrowhead Watershed study unit, 2010, California Groundwater Ambient Monitoring and Assessment (GAMA) Priority Basin Project.

[The five-digit number in parentheses below the constituent name is the USGS parameter code used to uniquely identify a specific constituent or property. USGS-GAMA site identification numbers: BEAR-G, Lake Arrowhead Watershed study area grid site; BEAR-S, Bear Valley study area grid site;

BEAR-U, Bear Valley and Lake Arrowhead Watershed study unit understanding site. Measurement errors: Helium-3/Helium-4 ratios, 1 percent error; helium-4, argon, and neon concentrations, 2 percent error; krypton and xenon concentrations, 3 percent error. Median error for modeled recharged temperatures is $0.32{ }^{\circ} \mathrm{C}$. Abbreviations: $\mathrm{cm}^{3} \mathrm{STP} / \mathrm{g}^{-1} \mathrm{H}_{2} 0$, cubic centimeters at standard temperature and pressure per gram of water; ${ }^{\circ} \mathrm{C}$, degrees Celsius]

\begin{tabular}{|c|c|c|c|c|c|c|}
\hline \multirow{2}{*}{$\begin{array}{c}\text { USGS-GAMA } \\
\text { site } \\
\text { identification } \\
\text { number }\end{array}$} & $\begin{array}{c}\text { Helium-3/ Helium-4 } \\
\text { (atom ratio) } \\
(61040)\end{array}$ & $\begin{array}{c}\text { Helium-4 } \\
\left(\mathrm{cm}^{3} \mathrm{STP} / \mathrm{g}^{-1} \mathrm{H}_{2} \mathrm{O}\right) \\
(85561)\end{array}$ & $\begin{array}{c}\text { Neon } \\
\left(\mathrm{cm}^{3} \mathrm{STP} / \mathrm{g}^{-1} \mathrm{H}_{2} \mathrm{O}\right) \\
(61046)\end{array}$ & $\begin{array}{c}\text { Argon } \\
\left(\mathrm{cm}^{3} \mathrm{STP} / \mathrm{g}^{-1} \mathrm{H}_{2} \mathrm{O}\right) \\
(85563)\end{array}$ & $\begin{array}{c}\text { Krypton } \\
\left(\mathrm{cm}^{3} \mathrm{STP} / \mathrm{g}^{-1} \mathrm{H}_{2} \mathrm{O}\right) \\
(85565)\end{array}$ & $\begin{array}{c}\text { Xenon } \\
\left(\mathrm{cm}^{3} \mathrm{STP} / \mathrm{g}^{-1} \mathrm{H}_{2} \mathrm{O}\right) \\
(85567)\end{array}$ \\
\hline & $\times 10^{-6}$ & $\times 10^{-8}$ & $\times 10^{-7}$ & $\times 10^{-4}$ & $\times 10^{-8}$ & $\times 10^{-8}$ \\
\hline \multicolumn{7}{|c|}{ Bear Valley study area grid sites } \\
\hline BEAR-S01 & 0.77 & 13.21 & 2.50 & 3.73 & 8.39 & 1.16 \\
\hline BEAR-S02 & 1.36 & 3.70 & 1.64 & 3.04 & 7.24 & 1.03 \\
\hline BEAR-S04 & 0.47 & 19.66 & 2.20 & 3.41 & 7.65 & 1.08 \\
\hline BEAR-S05 & 0.82 & 8.60 & 2.05 & 3.54 & 8.58 & 1.17 \\
\hline BEAR-S06 & 1.49 & 18.16 & 6.12 & 5.60 & 1.08 & 1.45 \\
\hline BEAR-S10 & 0.60 & 12.40 & 2.50 & 3.57 & 7.74 & 1.06 \\
\hline BEAR-S11 & 1.36 & 12.95 & 3.55 & 4.22 & 8.98 & 1.23 \\
\hline BEAR-S12 & 0.25 & 42.07 & 2.28 & 3.53 & 8.08 & 1.12 \\
\hline BEAR-S13 & 1.33 & 4.75 & 1.95 & 3.26 & 7.60 & 1.06 \\
\hline BEAR-S14 & 1.34 & 3.44 & 1.55 & 2.91 & 6.89 & 1.00 \\
\hline BEAR-U02 & 0.30 & 53.35 & 3.31 & 3.90 & 8.09 & 1.04 \\
\hline BEAR-U03 & 1.23 & 5.19 & 1.97 & 3.21 & 7.19 & 1.03 \\
\hline
\end{tabular}


Table 2-1. Analytical results from the Lawrence Livermore National Laboratory (LLNL) for dissolved noble gases and helium isotope ratios in groundwater samples collected by U.S. Geological Survey (USGS) for the Bear Valley and Lake Arrowhead Watershed study unit, 2010, California Groundwater Ambient Monitoring and Assessment (GAMA) Priority Basin Project.-Continued

[The five-digit number in parentheses below the constituent name is the USGS parameter code used to uniquely identify a specific constituent or property. USGS-GAMA site identification numbers: BEAR-G, Lake Arrowhead Watershed study area grid site; BEAR-S, Bear Valley study area grid site; BEAR-U, Bear Valley and Lake Arrowhead Watershed study unit understanding site. Measurement errors: Helium-3/Helium-4 ratios, 1 percent error; helium-4, argon, and neon concentrations, 2 percent error; krypton and xenon concentrations, 3 percent error. Median error for modeled recharged temperatures is $0.32{ }^{\circ} \mathrm{C}$. Abbreviations: $\mathrm{cm}^{3} \mathrm{STP} / \mathrm{g}^{-1} \mathrm{H}_{2} 0$, cubic centimeters at standard temperature and pressure per gram of water; ${ }^{\circ} \mathrm{C}$, degrees Celsius]

\begin{tabular}{|c|c|c|c|c|c|c|}
\hline \multirow{2}{*}{$\begin{array}{l}\text { USGS-GAMA } \\
\text { site } \\
\text { identification } \\
\text { number }\end{array}$} & $\begin{array}{c}\text { Helium-3/ Helium-4 } \\
\text { (atom ratio) } \\
(61040)\end{array}$ & $\begin{array}{c}\text { Helium-4 } \\
\left(\mathrm{cm}^{3} \mathrm{STP} / \mathrm{g}^{-1} \mathrm{H}_{2} \mathrm{O}\right) \\
(85561)\end{array}$ & $\begin{array}{c}\text { Neon } \\
\left(\mathrm{cm}^{3} \mathrm{STP} / \mathrm{g}^{-1} \mathrm{H}_{2} \mathrm{O}\right) \\
(61046)\end{array}$ & $\begin{array}{c}\text { Argon } \\
\left(\mathrm{cm}^{3} \mathrm{STP} / \mathrm{g}^{-1} \mathrm{H}_{2} \mathrm{O}\right) \\
(85563)\end{array}$ & $\begin{array}{c}\text { Krypton } \\
\left(\mathrm{cm}^{3} \mathrm{STP} / \mathrm{g}^{-1} \mathrm{H}_{2} \mathrm{O}\right) \\
(85565)\end{array}$ & $\begin{array}{c}\text { Xenon } \\
\left(\mathrm{cm}^{3} \mathrm{STP} / \mathrm{g}^{-1} \mathrm{H}_{2} \mathrm{O}\right) \\
(85567)\end{array}$ \\
\hline & $\times 10^{-6}$ & $\times 10^{-8}$ & $\times 10^{-7}$ & $\times 10^{-4}$ & $\times 10^{-8}$ & $\times 10^{-8}$ \\
\hline \multicolumn{7}{|c|}{ Lake Arrowhead Watershed study area sites } \\
\hline BEAR-G01 & 0.38 & 47.12 & 4.59 & 4.75 & 9.28 & 1.26 \\
\hline BEAR-G02 & 1.37 & 10.90 & 3.84 & 4.59 & 9.23 & 1.19 \\
\hline BEAR-G04 & 1.17 & 6.98 & 2.42 & 3.86 & 8.59 & 1.20 \\
\hline BEAR-G05 & 1.19 & 8.81 & 2.52 & 4.21 & 9.51 & 1.40 \\
\hline BEAR-G06 & 1.22 & 6.13 & 2.38 & 3.91 & 8.83 & 1.16 \\
\hline BEAR-G10 & 0.90 & 9.27 & 2.58 & 3.89 & 8.65 & 1.20 \\
\hline BEAR-G11 & 1.23 & 5.20 & 2.11 & 3.84 & 8.72 & 1.20 \\
\hline BEAR-G12 & 0.82 & 9.43 & 2.33 & 3.60 & 8.41 & 1.18 \\
\hline BEAR-G13 & 1.13 & 8.00 & 2.53 & 3.77 & 8.57 & 1.13 \\
\hline BEAR-U01 & 1.03 & 10.30 & 2.76 & 3.96 & 8.43 & 1.10 \\
\hline BEAR-U05 & 1.33 & 3.43 & 1.38 & 3.29 & 8.09 & 1.23 \\
\hline BEAR-U10 & 1.37 & 7.25 & 2.92 & 4.17 & 9.28 & 1.24 \\
\hline
\end{tabular}




\section{References Cited}

Mathany, T.M., and Belitz, Kenneth, 2013, Groundwaterquality data in the Bear Valley and selected Hard Rock Areas study unit, 2010-Results from the California GAMA Program: U.S. Geological Survey Data Series 747, 86 p., https://pubs.usgs.gov/ds/747/. 

Publishing support provided by the U.S. Geological Survey Science Publishing Network, Sacramento Publishing Service Center

For more information concerning the research in this report, contact the Director, California Water Science Center U.S. Geological Survey 6000 J Street, Placer Hall Sacramento, California 95819 http://ca.water.usgs.gov 


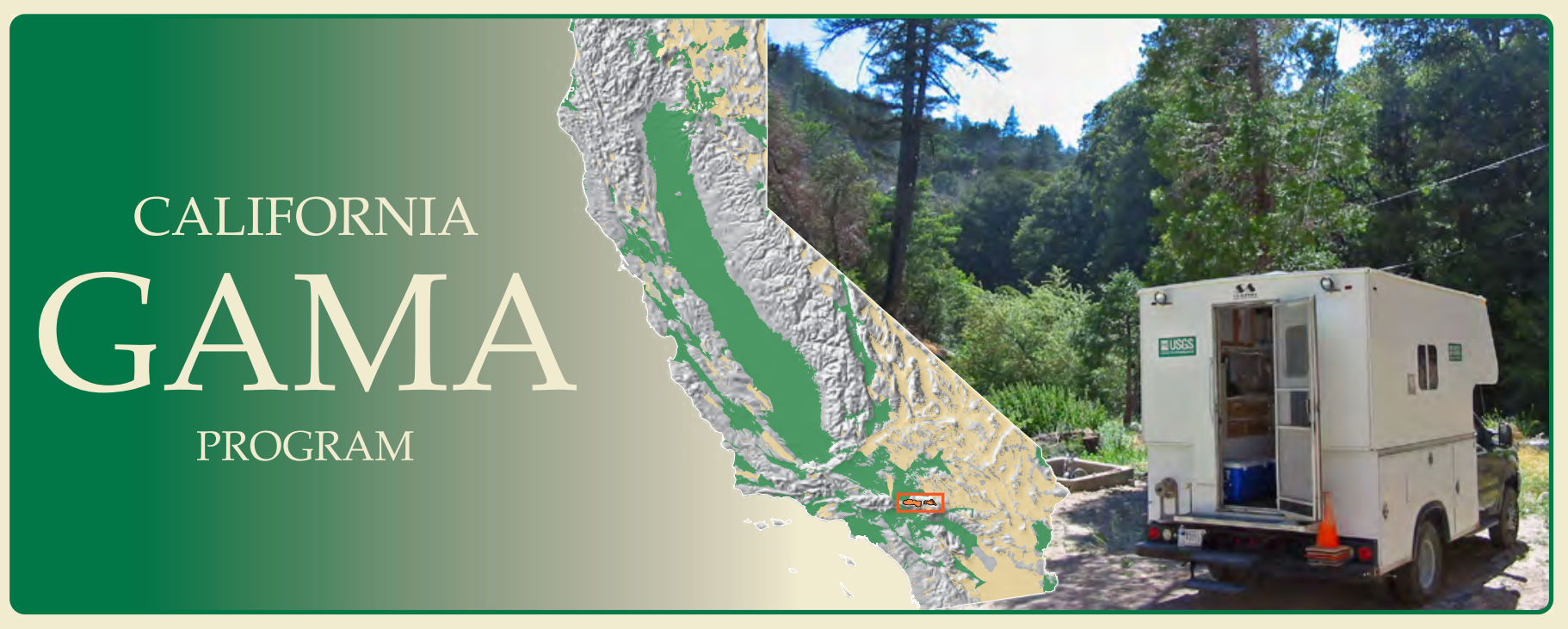

